\title{
POHREBISKO Z 9. STOROČIA V NITRE-DOLNÝCH KRŠKANOCH ${ }^{1}$
}

\author{
MIL A N H A ULIAK - + B OH USL AV CHROPOVSKÝ
}

\begin{abstract}
Burial Place from $9^{\text {th }}$ Century in Nitra-Dolné Krškany. The study presents results obtained from the analysis of 54 graves. They were examined in the western and eastern part of the burial place in 1976. The central part and peripheral sections were not uncovered. In spite of it, it is clear that the graves were placed in eight groups that were filled with different intensity. The components of the burial rite have almost uniform appearance. Deviations from the standard placement of body remains are not of higher intensity; their more frequent occurrence is missing. This also applies to the shape and size of grave pits in full extent. Remains of wooden constructions of different types are even more rare. Exceptional defense practices performed on the buried individuals were in line with the then pre-Christian principles. Their influence was manifested also during demarcation of the orientation of the deceased, at placement of the burial place in the local natural environment. The composition of the burial inventory, which is represent by 30 main types and their variants, brings lower quality of knowledge. The value of knowledge is lowered by marked occurrence of representatives from the group of ritual character and daily requirements. Their dating ability is very low up to negligible. Earrings of the so called danubian and veligradian jewellery types do not bring information of better quality as well. Their specimen do not occur in stable combinations with other objects. They are situated in graves placed in two parts of the necropolis that are separated by the uncovered part. Burying in the burial place can be dated only in general into the first and second half of $9^{\text {th }} \mathrm{c}$. because of lack of data at disposal. We are not able to determine how long was the burial place used as we have neither the initial nor the final section at disposal. With definitive validity it is also not possible to confirm the continuous process of burying, which was noticed only as indication, directed from the western to eastern part of the necropolis. However, in spite of the limited quality of input data it is possible to sort out a small group of individuals with higher or more prestigious status in the local community.
\end{abstract}

Keywords: western Slovakia, Early Middle Ages, burial customs, material culture, structure of burying and of community.

\section{ÚVOD}

K juhovýchodnému obvodu historickej Nitry sa v 9. stor. pripojila sídelná enkláva so zhlukom sídliskových a pohrebiskových lokalít. Z východnej strany vymedzovalo tento mikroregión riečne koryto starej Nitry, západnú líniu zasa s riekou súbežná vrcholová čast' pahorkatiny. Zhruba stredom tohto územia prechádza významná trasa dávnovekej dial'kovej cesty smerujúca z Konštantínopola cez Ostrihom a vel'komoravskú Nitravu do Prahy ( $L u$ kačka 2002, 208; Slivka 1998, 261).

$\mathrm{V}$ uvedenom priestore sa neskôr sformovala vrcholnostredoveká dedina Dvorčany (Deuorchan). Prvá písomná zmienka z roku 1240 ju spája s majetkami Zoborského kláštora. V priebehu následného vývoja sa sídliskový útvar stal súčastou jednotného katastra dediny Krškany (Kereskény). Počas novoveku sa južná čast̉ jej intravilánu zmenila na hromadnú ulicovú dedinu priliehajúcu $\mathrm{k}$ cestnej komunikácii spájajúcej Nitru s Novými Zámkami. Prevažujúci polnohospodársky potenciál miestnych obyvatelov sa pozvolne menil od začiatku 60 . rokov minulého storočia, ked' sa v južných úsekoch katastrálneho územia začali budovat’ areály so skladovacími, prevádzkovými a výrobnými objektmi. Po polovici 70. rokov k nim pribudla aj pobočka topolčianskeho podniku zameraného na výrobu nábytku (závod Mier) označovaného miestnymi obyvatelmi ako Nábytkáreň (obr. 1; Chropovský 1964; Marsina 1977; Vlastivedný slovník 1977, 296).

\section{LOKALITA}

Počiatky archeologických aktivít $\mathrm{v}$ neskoršom podnikovom areáli budovanom v najjužnejšej okrajovej zóne dolnokrškanského katastra sa posúvajú k 8. júlu, s pokračovaním 14.-16. júla 1976. Vtedy sa počas terénnych úprav a stavebných prác na budove pre pomocnú prevádzku značne porušili tri hroby, d’alšie štyri hroby sa odkryli a odborne zdokumentovali. K systematickému odkryvu pohrebiska, realizovanému od 18. augusta do 28 . októbra sa pristúpilo až na základe d’alších ludských skeletov zaznamenaných $\mathrm{v}$ kanalizačnej ryhe vzdialenej takmer $30 \mathrm{~m}$ od miesta s prvotným výskytom hrobov. Na ploche vymedzenej obomi líniami sa

\footnotetext{
1 Štúdia vznikla s podporou projektov APVV-16-449 „Stredoveká Nitra v hmotných prameňoch“ a 2/0037/17 Agentúry VEGA „Úloha materiálnej kultúry pri formovaní ekonomických, sociálnych a interetnických väzieb v stredovekých komunitách".
} 


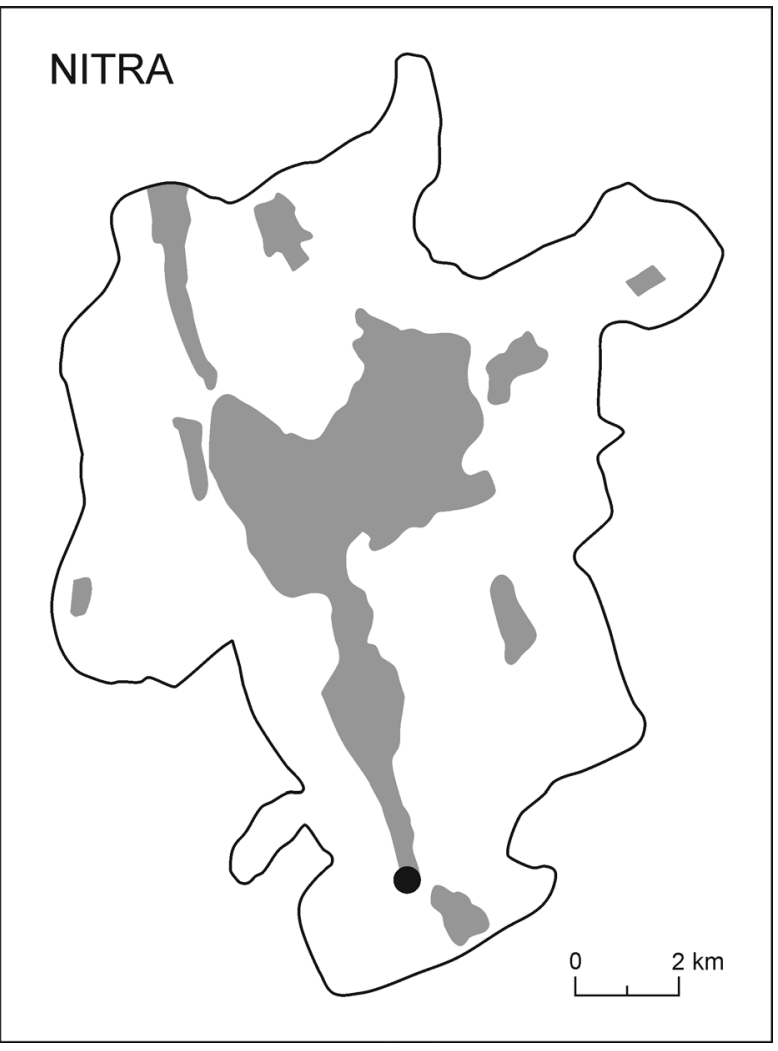

Obr. 1. Územie Nitry s vyznačenou polohou spracúvanej lokality.

v roku 1976 počas odkryvu zdokumentovalo 53 hrobov. Posledný hrob, objavený pri kopaní jamy pre elektrický stlp, pribudol do súboru v apríli 1979. Jeho poloha z juhovýchodného úseku nekropoly sa na základe zistených koordinátov zakreslila do celkového plánu. Post vedúceho výskumu, s autorskými právami na celý nálezový fond, prevzal B. Chropovský. Práce v teréne viedla a nálezové situácie dokumentovala A. Kováčová, technická pracovníčka Archeologického ústavu SAV, ktorá vyhotovila nálezovú správu.

$\mathrm{K}$ najdôležitejším študijným prameňom $\mathrm{z}$ nálezovej správy patria plány hrobov vyhotovené v mierke 1 : 10 s opismi nálezových situácií a kresbami predmetov pohrebného inventára na dokumentačných kartách. V spolupráci s $\mathrm{A}$. Kováčovou bola prvotná podoba celkového plánu pozmenená tak, aby sa situácia v potrebnej miere stotožňovala $\mathrm{s}$ reálnym stavom. Kulahčeniu sledovania priestorových vztahov boli na tomto pláne vyznačené obvodové línie zoskupených hrobov, doplnila sa pomocná sektorová siet potrebná k identifikácii ich pozície. Konzultáciami s A. Kováčovou sa takisto odstránili niektoré sporné momenty a doplnili detaily, ktoré boli zaznamenávané podla niekdajších noriem.

\section{KATALÓG}

Hrob 1 (C/1; tab. I)

Obrys hrobovej jamy nebol zdokumentovaný. Kostra detského jedinca (inf. III), uložená hlavou západným smerom, spočívala údajne na chrbte (hí. 130 cm). Kosti porušené výkopovými prácami boli odstránené z hrobu. Konča chodidiel nádoba (1).

Opis nálezov

1. Hrncovitá keramická nádoba misovitého tvaru, ústie s kuželovito zrezaným okrajom, horná polovica tela dodatočne obtočená. Na hrdle pás vlnovky, na vydutine desat horizontálnych línií vyhotovených jednohrotým rydlom. Na vyklenutom dne v obvodovom prstenci odtlačky drevenej podložky a obilných zrniek. V keramickej hmote jemný piesok. Kvalitný výpal, farba hnedá s ružovým odtieňom; pr. ústia $142 \mathrm{~mm}$, pr. vydutiny 147 mm, pr. dna 90 mm, v. 135 mm (tab. I: 1: 1).

Hrob 2 (C/1; tab. I)

Obrys hrobovej jamy nebol zdokumentovaný. Kostra dospelého muža (M, mat. II), uložená hlavou západným smerom, spočivala údajne na chrbte (hí. 100 cm). Kosti porušené výkopovými prácami boli odstránené z hrobu. Pri kostiach nôž (1).

Opis nálezov

1. Železný nôž s rovným chrbtom, čepel'ou zaoblenou k hrotu zo spodnej strany, s obojstranne zúženým pásikovým tŕňom; dí. $132 \mathrm{~mm}$, š. čepele $14 \mathrm{~mm}$ (tab. I: 2: 1).

Hrob 3 (A/1; tab. I)

Obrys hrobovej jamy nebol zdokumentovaný. Kostra dospelého muža (M, mat. I), uložená hlavou západným smerom spočívala údajne na chrbte (hí. 100 cm). Kosti porušené výkopovými prácami boli odstránené z hrobu. Konča chodidiel nádoba (1).

Opis nálezov

1. Hrncovitá keramická nádoba vajcovitého tvaru, ústie so zaobleným okrajom, hrdlo dodatočne obtočené. Na podhrdlí štyri horizontálne línie vyhotovené jednohrotým rydlom. Dno minimálne vyklenuté. V keramickej hmote hrubý piesok s vyšším podielom stredne vel'kých až vel'kých kamienkov vystupujúcich na povrch v dolnej častí nádoby. Výpal nižšej kvality, farba čiernohnedá; pr. ústia $97 \mathrm{~mm}$, pr. vydutiny $117 \mathrm{~mm}$, pr. dna $70 \mathrm{~mm}$, v. $110 \mathrm{~mm}$ (tab. I: 3: 1).

Hrob 4 (A/1; tab. I; II)

Oválny obrys hrobovej jamy (220 x 40-65-45 cm) s vyklenutými koncovými stranami. Kostra dospelého muža (M, mat.), orientovaná v línii $245^{\circ}$, leží na chrbte (hí. $142 \mathrm{~cm}$ ). Lebka spočíva na zátylku, pravé predlaktie smeruje do panvy, lavé predlaktie a dolné končatiny v osi skeletu. Pod pravou častou jedinca pozdĺžny úsek tenkej vrstvy uhlíkov v tmavo sfarbenej zemine $(172 \times 12-27 \mathrm{~cm})$. Vlavo od lebky hrot kopije (1), vedla lavého kolena zhluk predmetov pozostávajúci z noža (2), fragmentu noža (3), šidla (4), britvy (5) a úštepov (6).

Opis nálezov

1. Železná kopija s úzkym listovitým hrotom (dí. $233 \mathrm{~mm}$, š. $35 \mathrm{~mm}$ ), napojeným na kuželovitú tulajku (dí. 114 mm, pr. 16-30 mm); celková dí. 347 mm (tab. II: 4: 1). 
2. Železný nôž s rovným chrbtom, čepel’ou zaoblenou k hrotu zo spodnej strany, s obojstranne zúženým tŕňom; dí. 158 mm, š. čepele 16 mm (tab. II: 4: 2).

3. Zlomok z čepele železného noža s rovnou líniou chrbta, ostrím smerujúcim šikmo k hrotu; dí. 76 mm, š. 16 mm (tab. I: 4: 3).

4. Šidlo zo železnej tyčinky štvorhranného prierezu (hr. $2,5 \times 2,5 \mathrm{~mm}$ ) upravenej do pracovnej časti s kruhovitým prierezom (hr. $2 \mathrm{~mm}$ ); dí. $77 \mathrm{~mm}$ (tab. I: 4: 4).

5. Britva pozostávajúca $\mathrm{z}$ čepele železného noža $\mathrm{s}$ trojuholníkovito vyklenutým ukončením (dí. $92 \mathrm{~mm}$, š. 18-25 mm), chráneného lichobežníkovitým puzdrom z prehnutého plechu; celková dí. $83 \mathrm{~mm}$, š. 22-30 mm (tab. II: 4: 5).

6/1. Úštep pozdĺžneho trojuholníkovitého tvaru zo silicitu; dí. 23 mm, š. 12 mm (tab. II: 4: 6/1).

6/2.Úštep trojuholníkovitého tvaru zo silicitu; dí. 17 mm, š. $14 \mathrm{~mm}$ (tab. II: 4: 6/2).

Hrob 5 (C/1; tab. II)

Obdížnikovitý obrys hrobovej jamy $(210 \times 72-63 \mathrm{~cm})$ so zaoblenými rohmi. Kostra dospelého muža (M, mat. II), orientovaná v línii $260^{\circ}$, leží na chrbte (hí. $150 \mathrm{~cm}$ ). Lebka spočíva na l'avom spánku, kosti oboch predlaktí druhotne presunuté, dolné končatiny v osi skeletu. Konča chodidiel zhluk predmetov pozostávajúci zo spony (1), šidla (2), úštepov (3), britvy (4).

Opis nálezov

1. Kruhová spona s gul’ovito zhrubnutými koncami ramien z bronzovej tyčinky kruhového prierezu, doplnená jazýčkom; pr. 38 cm, hr. 2,5 mm (tab. II: 5: 1).

2. Sidlo zo železnej tyčinky štvorhranného prierezu (hr. $3,5 \times 3,5 \mathrm{~mm}$ ) upravenej do pracovnej časti s kruhovitým prierezom (pr. $5 \mathrm{~mm}$ ); dí. $55 \mathrm{~mm}$ (tab. II: 5: 2).

3/1. Uštep trojuholníkovitého tvaru z limnosilicitu; dí. 27 mm, š. 15 mm (tab. II: 5: 3/1).

3/2. Úštep pozdĺžneho tvaru z rádiolaritu; dí. $30 \mathrm{~mm}$, š. 13 mm (tab. II: 5: 3/2).

4. Britva pozostávajúca z čepele železného noža s koncovým výčnelkom (dí. 92 mm, š. 12-15mm), chráneného lichobežníkovitým puzdrom z prehnutého plechu; celková dí. 98 mm, š. 15-22 mm (tab. II: 5: 4).

Hrob 6 (B/1; tab. III)

Obdížnikovitý obrys hrobovej jamy $(246$ x $72 \mathrm{~cm})$ s vyklenutou hornou koncovou stranou, zvyšné rohy zaoblené. Kostra dospelého muža (M, mat. II), orientovaná v línii 255, leží na chrbte (hí. 200 cm). Lebka spočíva na zátylku, horné a dolné končatiny v osi skeletu. V strede hrudníka nôž (1), konča chodidiel vedro (2).

Opis nálezov

1. Železný nôž s rovným chrbtom mierne skoseným k hrotu, s čepelou zaoblenou k hrotu zo spodnej strany, odspodu odsadeným pásikovým tŕňom. Jeho predížená čast' zasunutá do rukoväte z dvoch kostených platničiek upevnených dvomi nitmi. Povrch rukoväte zdobený koncentrickými krúžkami; dí. $236 \mathrm{~mm}$, š. čepele $16 \mathrm{~mm}$ (tab. III: 6: 1).

2. Z pôvodných železných súčastí vedra sa zachovalo 37 fragmentov. K nim patrí držadlo z tyčinky štvorhranného prierezu (hr. 4 × $4 \mathrm{~mm}$ ) s priemerom $160 \mathrm{~mm}$, vyklenuté $72 \mathrm{~mm}$. Jeho oblúkovito prehnuté gombíkovito rozkuté konce boli zasunuté do otvorov závesných kovaní v tvare obráteného motívu T s vykrojeným uchom (š. 20-70 mm, dí. 80 mm). Tri obruče z plochého pásika (hr. 1,5 mm) sú široké 7,6 a $8 \mathrm{~mm}$. Horná obruč je k dreveným dyhám pripevnená pomocou štvorice nitov umiestnených na štyroch krížových kovaniach. Predpokladané rozmery vedierka: pr. $160-178 \mathrm{~mm}$, v. $150 \mathrm{~mm}$ (tab. III: 6: 2).

Hrob 7 (B/1; tab. IV)

Obdížnikovitý obrys hrobovej jamy (195 x 47-65cm) s vyklenutými koncovými stranami. Kostra dospelého muža (M, mat. I), orientovaná v línii $245^{\circ}$, leží na chrbte (hí. $120 \mathrm{~cm}$ ). Lebka nachýlená na pravý spánok, pravé predlaktie smeruje do panvy, l’avá horná končatina a dolné končatiny v osi skeletu. V strede lavej časti hrudníka ociel'ky (1), úštep (2), v pravej časti panvy nôž (3).

Opis nálezor

1/1.Železná ociel'ka oválneho tvaru s chýbajúcim pravým ramenom; dí. 58 mm, š. 25 mm (tab IV: 7: 1/1).

1/2.Železná ociel'ka oválneho tvaru s chýbajúcou pravou polovicou tela; dí. $36 \mathrm{~mm}$, š. $35 \mathrm{~mm}$ (tab IV: 7: 1/2).

2. Úštep pozdížneho tvaru z rádiolaritu; dí. $18 \mathrm{~mm}$, š. $10 \mathrm{~mm}$ (tab. IV: 7: 2).

3. Železný nôž s rovným chrbtom, čepel'ou zaoblenou k hrotu zo spodnej strany, obojstranne odsadeným tŕňom; dí. 136 mm, š. čepele 16 mm (tab. IV: 7: 3).

Hrob 8 (A/2; tab. IV; V)

Obdížnikovitý obrys hrobovej jamy $(155$ x 65-70 cm) s vyklenutými koncovými stranami. Kostra detského jedinca (inf. II), orientovaná v línii $253^{\circ}$, leží na chrbte (hí. 150 cm). Lebka nachýlená na l’avý spánok, predlaktia a stehenné kosti strávené, zvyšné kosti v osi skeletu. Konča pravého chodidla sekera (1), hrkálka (2), opodial’ nôž (3) a nádoba (4).

Opis nálezov

1. Úzka železná sekera s vejárovite rozšíreným telom, mierne skloneným oblúkovým ostrím (š. 30 mm), nízkymi trojuholníkovitými lalokmi pri zvislom otvore pre porisko (pr. $19 \times 16 \mathrm{~mm}$ ), krátkym obuchom s kvadratickým prierezom (pr. $8 \times 9 \mathrm{~mm}$, dí. $16 \mathrm{~mm}$ ); celková dí. 138 mm (tab. IV: 8: 1).

2. Hrkálka gulovitého tvaru s pásikovým uškom odliata z bronzu. Spodná čast’ tela členená štrbinovým otvorom $\mathrm{v}$ tvare kríža s kruhovito rozšírenými koncami; pr. 22 mm (tab. IV: 8: 2).

3. Železný nôž s rovným chrbtom, čepelou zaoblenou k hrotu zo spodnej strany, obojstranne zúženým tŕňom; dí. 54 mm, š. čepele 10 mm (tab. IV: 8: 3).

4. Hrncovitá keramická nádoba súdkovitého tvaru, ústie s kuželovito zrezaným okrajom, horná tretina tela dodatočne obtočená. Na hrdle horizontálny pás troch obežných línií vyhotovených jednohrotým rydlom. Na mierne vyklenutom dne nepravidelný obvodový prstenec a náhodný vryp. V keramickej hmote hrubý piesok. Kvalitný výpal, farba tmavohnedá; pr. ústia 105 mm, pr. vydutiny $130 \mathrm{~mm}$, pr. dna $70 \mathrm{~mm}$, v. $165 \mathrm{~mm}$ (tab. V: 8: 4).

Hrob 9 (A/2; tab. V)

Obdĺžnikovitý obrys hrobovej jamy $(165$ x $55 \mathrm{~cm}) \mathrm{s}$ pravouhlými až zaoblenými rohmi. Kostra dospelej ženy (F, ad. II), orientovaná v línii $255^{\circ}$, leží na chrbte (hí. $140 \mathrm{~cm}$ ). Lebka spočíva na lavom spánku s pohladom nadol, horné a dolné končatiny $\mathrm{v}$ osi skeletu.

Bez nálezov. 
Hrob 10 (B/2; tab. V)

Obdížnikovitý obrys hrobovej jamy (135+ x 90 cm) s vyklenutou hornou koncovou stranou, spodný úsek hrobu zničený výkopom. Kostra detského jedinca (inf. III), orientovaná v línii $253^{\circ}$, leží na chrbte (hí. 130 cm). Lebka spočíva na l’avom spánku, horné končatiny a stehenné kosti v osi skeletu, predkolenné kosti strávené. Vedl’a lavej časti panvy nôž (1), v pravom dolnom sektore hrobu nádoba (2).

Opis nálezov

1. Zlomok z čepele železného noža s rovnou líniou chrbta i ostria; dí. 45 mm, š. 11 mm (tab. V: 10: 1).

2. Hrncovitá keramická nádoba misovitého tvaru, ústie so zaobleným okrajom, hrdlo dodatočne obtočené. Na podhrdlí línia vlnovky vyhotovená jednohrotým rydlom. Na nadmerne zhrubnutom mierne vyklenutom dne nízky reliéf kruhu v obvodovom prstenci. V keramickej hmote hrubý piesok s vyšším podielom stredne vel'kých až vel'kých kamienkov vystupujúcich na povrch v dolnej časti nádoby. Výpal nižšej kvality, farba čiernohnedá; pr. ústia $130 \mathrm{~mm}$, pr. vydutiny $128 \mathrm{~mm}$, pr. dna $60 \mathrm{~mm}$, v. $105 \mathrm{~mm}$ (tab. V: 10: 2).

Hrob 11 (B-C/2; tab. VI)

Lichobežníkovitý obrys hrobovej jamy (153 x 60-80 cm) so zaoblenými rohmi v strednom úseku zničený výkopom. Kostra detského jedinca (inf. II), orientovaná v línii $252^{\circ}$ (hí. $130 \mathrm{~cm}$ ). Okrem zvyškov lebky ostatné kosti akiste strávené. Pri lavej stene $\mathrm{z}$ horného úseku hrobovej jamy zvieracie kosti (1), v pravom dolnom sektore hrobu nádoba (2).

Opis nálezov

1. Pät kostí z hydiny (Gallus gallus dom.).

2. Hrncovitá keramická nádoba misovitého tvaru, ústie so zaobleným okrajom, horná štvrtina tela dodatočne obtočená. Na podhrdlí pás vlnovky a horizontálny pás vyhotovený hrebeňom s tromi zubmi. Na vyklenutom dne plastický motív svastiky. V keramickej hmote jemný piesok. Kvalitný výpal, farba okrovožltá; pr. ústia $102 \mathrm{~mm}$, pr. vydutiny $118 \mathrm{~mm}$, pr. dna $70 \mathrm{~mm}$, v. $98 \mathrm{~mm}$ (tab. VI: 11: 2).

Hrob 12 (A/2; tab. VI)

Obdížnikovitý obrys hrobovej jamy (180+ x 63-81 cm) s vyklenutou hornou koncovou stranou. Dolný úsek hrobu zničený výkopom. Kostra dospelého muža (M, mat. I), orientovaná v línii $259^{\circ}$, leží na chrbte (hí. $130 \mathrm{~cm}$ ). Horné končatiny a pravá dolná končatina v osi skeletu. Niekol'ko rebier a kosti lavej dolnej končatiny druhotne presunuté.

Bez nálezov.

Hrob 13 (C/2; tab. VI; VII)

Obdížnikovitý obrys hrobovej jamy $(190$ x 95 cm) so zaoblenými rohmi. Kostra detského jedinca (inf. I), orientovaná pôvodne v línii $67^{\circ}$ (hí. $170 \mathrm{~cm}$ ). Primárne uloženie jedinca neznáme $\mathrm{z}$ dôvodu premiestnenia skeletového materiálu, strávenia a odstránenia mnohých kostí z hrobu. V hornom úseku strednej časti hrobovej jamy gombík (1), nôž (2), nádoba (3), vedro (4), pri l’avej stene v strednom úseku hrobovej jamy zvieracie kosti (5).

Opis nálezov

1. Gombík so zvislo rebrovaným povrchom, členeným do ôsmich polí, z pozláteného bronzového plechu.
Hornú časṫ tela ukončuje vrchlík z hladkého plechu $\mathrm{s}$ drôteným uškom ovinutým drôtikom. Na spodnom póle granulka; pr. $16 \mathrm{~mm}$, v. $12 \mathrm{~mm}$ (tab. VI: 13: 1).

2. Železný nôž s rovným chrbtom oblúkovito skoseným $\mathrm{k}$ hrotu, čepelou zaoblenou $\mathrm{k}$ hrotu zo spodnej strany, obojstranne odsadeným predíženým tŕňom; dí. $141 \mathrm{~mm}$, š. čepele $16 \mathrm{~mm}$ (tab. VII: 13: 2).

3. Hrncovitá keramická nádoba vajcovitého tvaru, ústie s kuželovito zrezaným okrajom, horná štvrtina tela dodatočne obtočená. Na hrdle dva pásy zvislých, na vydutine pät pásov šikmých i vodorovných vrypov vyhotovených jednohrotým rydlom. Na mierne vyklenutom dne nezretelný odtlačok drevenej podložky. V keramickej hmote jemný piesok. Kvalitný výpal, farba tmavohnedá; pr. ústia $90 \mathrm{~mm}$, pr. vydutiny $104 \mathrm{~mm}$, pr. dna 55 mm, v. 134 mm (tab. VII: 13: 3).

4. Z pôvodných železných súčastí vedra sa zachovalo 28 fragmentov. K nim patrí držadlo z tyčinky kruhového prierezu (hr. 5-6 mm) s priemerom $135 \mathrm{~mm}$, vyklenuté $67 \mathrm{~mm}$. Jeho oblúkovito prehnuté gombíkovito rozkuté konce boli zasunuté do otvorov závesných kovaní lichobežníkovitého tvaru s vykrojeným uchom (š. 20-40 mm, dí. $70 \mathrm{~mm}$ ). Horná obruč z plechového pásika (hr. $2 \mathrm{~mm}$ ) široká $17 \mathrm{~mm}$. Stredná a dolná obruč s okrajmi skutými do obruby (hr. 2,5 mm) sú široké 45-47 mm, ich konce spája dvojica nitov. Predpokladané rozmery vedierka: pr. 137-152 mm, v. 168 mm (tab. VII: 13: 4).

5. Štyri kosti z hydiny (Gallus gallus dom.).

Hrob 14 (C/2; tab. VII; VIII)

Lichobežníkovitý obrys hrobovej jamy (255 x 90-123 cm) s pravouhlými až zaoblenými rohmi. Kostra dospelej ženy (F, mat. I), orientovaná v línii $248^{\circ}$, leží na chrbte (hí. 200 cm). Lebka nachýlená na pravý spánok, l’avé predlaktie smeruje do panvy, pravá horná končatina a dolné končatiny v osi skeletu. V strede čela náušnica (1), na lavom temene iná náušnica (2), napravo od lebky vajce (3), v lavej časti panvy nože $(4,5)$, pri lavej stene hrobu v úrovni panvy zvieracie kosti (6), v pravom dolnom sektore hrobu vedro (7).

Opis nálezov

1. Krúžková náušnica oválneho tvaru zo strieborného drôtu. Horná čast' oblúka štvorhranného prierezu (hr. $1,2 \times 1 \mathrm{~mm}$ ), spodná čast' mierne roztepaná (hr. 2,5 x 0,5 mm); pr. 18 x 14,5 mm (tab. VII: 14: 1).

2. Náušnica $s$ jednostranným bubienkovým záveskom zo striebra (pr. 3,5 mm) napojeným na oblúk pomocou pútka a granulovaného kŕčka. Oblúk náušnice zo štvorhranného drôtu (hr. $1 \times 1 \mathrm{~mm})$, jeho spodnú čast’ oddelenú drôteným uzlíkom pokrýva granulácia; pr. 17,5 x 15 mm, v. 22 mm (tab. VII: 14: 2).

3. Vaječné škrupiny.

4. Železný nôž s rovným chrbtom, s čepelou zaoblenou k hrotu zo spodnej strany, obojstranne zúženým pásikovým tŕňom; dí. 106 mm, š. čepele 17 mm (tab. VII: 14: 4).

5. Železný nôž s rovným chrbtom, s čepelou zaoblenou k hrotu zo spodnej strany, obojstranne odsadeným hrotitým tŕňom; dí. 105 mm, š. čepele 15 mm (tab. VII: 14: 5).

6. Osem kostí z hydiny (Gallus gallus dom.).

7. Z pôvodných železných súčastí vedra sa zachovalo 73 fragmentov. K nim patrí držadlo z tyčinky štvor- 
hranného prierezu (hr. $3 \times 5 \mathrm{~mm}$ ) s priemerom $120 \mathrm{~mm}$, vyklenuté $62 \mathrm{~mm}$. Jeho oblúkovito prehnuté mierne zhrubnuté konce boli zasunuté do otvorov závesných držadiel v tvare pásika (š. $18-20 \mathrm{~mm}$ ). Tri obruče z plechového pásika (hr. $2 \mathrm{~mm}$ ) sú široké $6-7 \mathrm{~mm}$, ich konce spája nit. Predpokladané rozmery vedierka: pr. 120-130 mm, v. 100 mm (tab. VIII: 14: 7).

Hrob 15 (B/2; tab. IX)

Obdížnikovitý obrys hrobovej jamy $(235$ x 76-90 cm) s vyklenutou hornou koncovou stranou, zvyšné rohy zaoblené. Kostra dospelej ženy (F, ad. I), orientovaná v línii 254으, leží na chrbte (hí. 210 cm). Lebka nachýlená na l’avý spánok, horné a dolné končatiny v osi skeletu. $Z$ vnútornej strany lavého lakta nôž (1), konča l’avého chodidla vedro (2)

Opis nálezov

1. Železný nôž s rovným chrbtom, s čepelou zaoblenou k hrotu zo spodnej strany, zhora odsadeným tŕňom; dí. 130 mm, š. čepele 14 mm (tab. IX: 15: 1).

2. Z pôvodných železných súčastí vedra sa zachovalo 42 fragmentov. $K$ nim patrí držadlo $z$ tyčinky štvorhranného prierezu (hr. $7 \times 5 \mathrm{~mm}$ ) s priemerom $165 \mathrm{~mm}$, vyklenuté $85 \mathrm{~mm}$. Jeho oblúkovito prehnuté mierne zhrubnuté konce boli zasunuté do otvorov pásikových závesných kovaní obdížnikovitého tvaru s prerazeným otvorom (š. 16-18 mm, dí. $58 \mathrm{~mm}$ ). Tri obruče z plechového pásika (hr. 1,5-2 mm) sú široké 9,16 a $19 \mathrm{~mm}$. Predpokladané rozmery vedierka: pr. 165-180 mm, v. $150 \mathrm{~mm}$ (tab. IX: 15: 2).

Hrob 16 (B/1; tab. VIII)

Obdížnikovitý obrys hrobovej jamy $(147 \times 72-80 \mathrm{~cm})$ so zaoblenými rohmi, koncové strany nad dnom mierne zošikmené. Kostra detského jedinca (inf. II), orientovaná pôvodne v línii $251^{\circ}($ hí. $140 \mathrm{~cm})$. Lebka nachýlená na l’avý spánok, zvyšné kosti strávené. V oblasti krku koráliky (1), v pôvodnom mieste predkolenia náušnice $(2,3)$. Opis nálezov

1. V náhrdelníku možno postrehnút jeden sploštený gul'ovitý korálik z tmavomodrého skla so žltými bodkami na troch kuželovito zvrstvených očkách z bieleho a modrého skla (pr. 19 mm, dí. 14 mm); jeden sploštený gulovitý korálik z čierneho skla zdobený dvojicou natavených žltých vlákien lemujúcich bodku zo žltého skla (pr. 4,5 mm, dí. $3 \mathrm{~mm}$ ); dva súdkovité koráliky z priehladného skla (pr. 2,5 mm, dí. 3,5 mm); dva viacnásobne členené koráliky z dvoch segmentov z modrého a žltého skla (pr. $2 \mathrm{~mm}$, dí. $3 \mathrm{~mm}$ ); sedem kotúčových korálikov z tmavomodrého skla (pr. 1,5-2,5 mm, dí. 1,3 mm); 16 krúžkových korálikov zo zeleného a žltého skla (pr. 1,2-1,7 mm, dí. 1-1,2 mm; tab. VIII: 16: 1).

2. Náušnica sjednostranným trojbokým hrozienkovým záveskom zloženým z troch vencov (pr. 4 mm, dí. 3,5 mm) z pozláteného bronzu. Oválny oblúk náušnice z drôtu kruhového prierezu (hr. 1,2 mm) členia dva drôtené uzlíky; pr. 20,5 x 16 mm, v. 22 mm (tab. VIII: 16: 2).

3. Z náušnice $z$ pozláteného bronzu, akiste identického typu ako náušnica 2, zachovaný iba zlomok oblúka s drôteným uzlíkom; pr. 17 x 16 mm (tab. VIII: 16: 3).

Hrob 17 (B/1; tab. X)

Obdĺžnikovitý obrys hrobovej jamy $(165$ x 97 cm) s vyklenutými koncovými stranami. Kostra detského jedinca (inf. II), orientovaná v línii $253^{\circ}$, leží na chrbte (hí. $180 \mathrm{~cm}$ ). Lebka spočíva na zátylku, horné a dolné končatiny v osi skeletu, kosti lavého predlaktia strávené. Nad pravým plecom gombík (1).

Opis nálezov

1. Gombík so splošteným gul'ovitým telom z bledozeleného skla s uškom z bronzového drôtu; pr. 11 x 7 mm, dí. $11 \mathrm{~mm}$ (tab. X: 17: 1).

Hrob 18 (A/1; tab. X)

Obdížnikovitý obrys hrobovej jamy $(205$ x 83-91 cm) s pravouhlými až zaoblenými rohmi. Kostra detského jedinca (inf. III), orientovaná v línii $286^{\circ}$, ležala pôvodne na chrbte (hí. $205 \mathrm{~cm}$ ). Lebka spočíva na zátylku, dolné končatiny v osi skeletu, kosti z hornej polovice trupu strávené. Po oboch stranách čela náušnice $(1,2)$, $\mathrm{v}$ pôvodnom mieste lavej časti panvy nôž (3), konča chodidiel vedro (4).

Opis nálezov

1. Náušnica s jednostranným dvojbokým hrozienkovým záveskom z dvoch vencov granúl (pr. $2 \mathrm{~mm}$, v. $3 \mathrm{~mm}$ ) zo striebra. Oválny oblúk náušnice z drôtu kruhového prierezu (hr. $1 \mathrm{~mm}$ ) členia dve dvojice zdvojených uzlíkov zo šikmo presekávaného drôtu; pr. 14 x 10,5 mm, v. $16 \mathrm{~mm}$ (tab. X: 18: 1).

2. Náušnica s jednostranným dvojbokým hrozienkovým záveskom z dvoch vencov granúl (pr. $2 \mathrm{~mm}, \mathrm{v} .3 \mathrm{~mm}$ ) zo striebra. Oválny oblúk náušnice z drôtu kruhového prierezu (hr. $1 \mathrm{~mm}$ ) členia dve dvojice zdvojených uzlíkov zo šikmo presekávaného drôtu; pr. 13 × 12 mm, v. 16,5 mm (tab. X: 18: 2).

3. Železný nôž s rovným chrbtom, s čepelou zaoblenou k hrotu zo spodnej strany, obojstranne odsadeným tŕňom; dí. 129 mm, š. čepele 12 mm (tab. X: 18: 3).

4. Z pôvodných železných súčastí vedra sa zachovalo 41 fragmentov. $\mathrm{K}$ nim patrí držadlo $\mathrm{z}$ tyčinky štvorhranného prierezu (hr. 2,5 x 2,5 mm) s priemerom $165 \mathrm{~mm}$, vyklenuté $85 \mathrm{~mm}$. Jeho oblúkovito prehnuté mierne zhrubnuté konce boli zasunuté do otvorov závesných kovaní kotvovito rozoklaného tvaru s prerazeným otvorom (š. 18-77 mm, dí. $70 \mathrm{~mm}$ ). Tri obruče z plechového pásika (hr. 1,8-2,1 mm) sú široké 14, 8 , $15 \mathrm{~mm}$, ich konce spája nit. Nad strednou obručou nitom upevnený krúžok z tyčinky kruhového prierezu (hr. $4 \mathrm{~mm}$; pr. $25 \mathrm{~mm}$ ). Predpokladané rozmery vedierka: pr. 127-150 mm, v. 133 mm (tab. X: 18: 4).

Hrob 19 (A/1; tab. XI)

Obdížnikovitý obrys hrobovej jamy $(138$ x $80 \mathrm{~cm})$ so zaoblenými rohmi. Kostra detského jedinca (inf. II), orientovaná pôvodne v línii $252^{\circ}$ (hí. $170 \mathrm{~cm}$ ). Lebka spočíva na zátylku, zvyšné kostí strávené. Pri lavom spánku náušnica (1).

Opis nálezov

1. Náušnica s jednostranným trojbokým hrozienkovým záveskom z jedného venca granúl (pr. 2 mm, v. 2 mm) zo striebra. Oválny oblúk náušnice z drôtu kruhového prierezu (hr. 1,2 mm) člení uzlík zo šikmo presekávaného drôtu; pr. 14 x 10,5 mm, v. 16,5 mm (tab. XI: 19: 1).

Hrob 20 (A/1; tab. XI)

Obdĺžnikovitý obrys hrobovej jamy $(190$ x 68-79 cm) so zaoblenými rohmi. Kostra dospelej ženy (F, mat. II), 
orientovaná v línii $258^{\circ}$, leží na chrbte (hí. 150 cm). Lebka spočíva na pravom spánku, pravé predlaktie smeruje do panvy, lavá horná končatina a dolné končatiny $\mathrm{v}$ osi skeletu, ktorý je $\mathrm{v}$ náznakoch nachýlený dolava. Z vnútornej strany lavého predlaktia nôž (1).

1. Železný nôž s rovným chrbtom, s čepelou zaoblenou k hrotu zo spodnej strany, obojstranne odsadeným tŕňom; dí. 137 mm, š. čepele 15 mm (tab. XI: 20: 1).

Hrob 21 (A/1; tab. XI)

Oválny obrys hrobovej jamy $(88$ x 40-57-35 cm) s vyklenutými koncovými stranami. Kostra dietata (inf. II), orientovaná v línii $261^{\circ}$, leží na chrbte (hí. $110 \mathrm{~cm}$ ). Lebka spočíva na zátylku, v laktoch mierne ohnuté horné končatiny v osi skeletu, dolné končatiny súbežne doprava pokrčené.

Bez nálezov.

Hrob 22 (A/1; tab. XI)

Obdĺžnikovitý obrys hrobovej jamy $(170$ x 65 cm) s vyklenutou dolnou koncovou stranou, zvyšné rohy zaoblené. Kostra dospelej ženy (F, mat. I), orientovaná v línii $261^{\circ}$, leží na chrbte. Lebka nachýlená na pravý spánok, lavé predlaktie smeruje do panvy, pravá horná končatina a dolné končatiny v osi skeletu.

Bez nálezov.

Hrob 23 (C/2; tab. XII)

Obdížnikovitý obrys hrobovej jamy $(170$ x $73 \mathrm{~cm})$ so zaoblenými rohmi. Kostra dospelej ženy (F, mat. I), orientovaná v línii $248^{\circ}$, leží na chrbte (hí. $90 \mathrm{~cm}$ ). Lebka spočíva na zátylku, horné a dolné končatiny v osi skeletu. Pri lavom spánku náušnica (1), pri pravom pleci nádoba (2).

Opis nálezov

1. Krúžková náušnica oválneho tvaru z bronzového drôtu kruhového prierezu, spodný oblúk oddelený dvomi drôtenými uzlíkmi (hr. 1,2 mm); pr. 20 x 15 mm (tab. XII: 23: 1).

2. Hrncovitá keramická nádoba súdkovitého tvaru, ústie so zaobleným okrajom, hrdlo dodatočne obtočené. Na podhrdlí pás vlnovky a horizontálnej línie vyhotovenej hrebeňom s tromi zubmi. Dno minimálne vyklenuté. V keramickej hmote hrubý piesok s vyšším podielom stredne vel'kých až vel'kých kamienkov. Výpal nižšej kvality, farba čiernohnedá; pr. ústia 110 mm, pr. vydutiny $135 \mathrm{~mm}$, pr. dna $81 \mathrm{~mm}$, v. 150 mm (tab. XII: 23: 2)

Hrob 24 (B/2; tab. XI)

Obrys hrobovej jamy nebol zdokumentovaný. Kostra detského jedinca (inf. III), orientovaná v línii $253^{\circ}$, leží na chrbte (hí. $90 \mathrm{~cm}$ ). Lebka spočíva na pravom spánku, horné a dolné končatiny v osi skeletu.

Bez nálezov.

\section{Hrob 25 (C/2; tab. XII)}

Obrys hrobovej jamy nebol zdokumentovaný. Kostra dospelého muža (M, mat. II) neležala v anatomickej polohe. Kosti sú druhotne uložené v zhluku s rozlohou $53 \mathrm{x}$ $33 \mathrm{~cm}$, orientovanom v línii $252^{\circ}$ (hí. $80 \mathrm{~cm}$ ). Za hrudnou kostou smerom nadol nasledovala fragmentarizovaná lebka a dlhé kosti z končatín, pod nimi ludská sánka. Predmetný zhluk je vzdialený necelých $20 \mathrm{~cm}$ od ramena kostry z hrobu 26.

Bez nálezov.
Hrob 26 (C/2; tab. XII)

Obrys hrobovej jamy nebol zdokumentovaný. Kostra dospelej ženy (F, mat.), orientovaná v línii $253^{\circ}$, leží na chrbte (hl. $80 \mathrm{~cm}$ ). Lebka spočíva na zátylku, lavé predlaktie smeruje do panvy, pravá horná končatina a dolné končatiny v osi skeletu. Pri hornom kíbe l’avej stehennej kosti pracka (1).

Opis nálezov

1. Polkruhová pracka zo železnej tyčinky štvorhranného prierezu (hr. 4 x $4 \mathrm{~mm}$ ) zachovaná v dvoch zlomkoch; pr. asi $27 \times 27 \mathrm{~mm}$ (tab. XII: 26: 1).

Hrob 27 (B/2; tab. XIII)

Obdĺžnikovitý obrys hrobovej jamy $(180$ x 86 cm) s vyklenutou dolnou koncovou stranou, zvyšné rohy zaoblené. Kostra dospelej ženy (F, mat. II), orientovaná v línii 247, leží na chrbte (hí. $130 \mathrm{~cm}$ ). Lebka spočíva na zátylku, pravé predlaktie smeruje do panvy, l’avé druhotne presunuté, l’avá čast' panvy chýba, dolné končatiny v osi skeletu. Na temene náušnica (1), pri l’avom spánku iná náušnica (2), z vnútornej strany l'avého lakt’a nôž (3), vedla pravého kolena praslen (4), cez pravé predkolenie leží nádoba (5), v l'avom dolnom sektore hrobu zvieracie kosti (6).

1. Krúžková náušnica oválneho tvaru z bronzového drôtu kruhového prierezu (hr. $1 \mathrm{~mm}$ ); pr. 14,5 x 10,5 mm (tab. XIII: 27: 1)

2. Krúžková náušnica oválneho tvaru z bronzového drôtu kruhového prierezu (hr. $1 \mathrm{~mm}$ ) s drôteným uzlíkom; pr. 14,5 x 13,5 mm (tab. XIII: 27: 2).

3. Železný nôž s rovným chrbtom, s čepelou zaoblenou k hrotu zo spodnej strany, obojstranne zúženým pásikovým tŕňom; dí. 85 mm, š. čepele 11 mm (tab. XIII: 27: 3).

4. Dvojkónický keramický praslen s preliačenou hornou plochou; pr. 20-24 mm, v. $21 \mathrm{~mm}$ (tab. XIII: 27: 4).

5. Hrncovitá keramická nádoba vajcovitého tvaru, ústie s kuželovito zrezaným okrajom, horná tretina tela dodatočne obtočená. Na podhrdlí dva pásy vlnovky, na vydutine horizontálny pás vyhotovený hrebeňom so štyrmi zubmi. Na mierne vyklenutom dne odtlačok obvodového prstenca. V keramickej hmote jemný piesok. Kvalitný výpal, farba tmavohnedá; pr. ústia 110 mm, pr. vydutiny $133 \mathrm{~mm}$, pr. dna $73 \mathrm{~mm}$, v. $165 \mathrm{~mm}$ (tab. XIII: 27: 5).

6. Osem kostí z hydiny (Gallus gallus dom.).

Hrob 28 (C/1; tab. XIII)

Obdĺžnikovitý obrys hrobovej jamy $(160+x 70 \mathrm{~cm})$ so zaoblenými rohmi, spodný úsek hrobu zničený výkopom. Kostra dospelej ženy (F, mat.), orientovaná v línii 253, leží na chrbte (hí. $80 \mathrm{~cm}$ ). Lebka spočíva na zátylku, horné a dolné končatiny $\mathrm{v}$ osi skeletu. V lavej časti panvy nôž (1).

Opis nálezov

1. Železný nôž s rovným chrbtom, s čepelou zaoblenou k hrotu zo spodnej strany, zhora odsadeným tŕňom; dí. $120 \mathrm{~mm}$, š. čepele $10 \mathrm{~mm}$ (tab. XIII: 28: 1).

Hrob 29 (C/1; tab. XIV)

Lichobežníkovitý obrys hrobovej jamy (205 x 95-63 cm) so zaoblenými rohmi. Kostra nedospelého jedinca (juv.), orientovaná v línii $242^{\circ}$, leží na chrbte (h1. $95 \mathrm{~cm}$ ). Lebka spočíva na zátylku, horné a dolné končatiny v osi skeletu. Pri lavom spánku náušnica (1). 
Opis nálezov

1. Náušnica s plechovým trubičkovým záveskom (pr. $2 \mathrm{~mm}, \mathrm{v} .4 \mathrm{~mm}$ ) z bronzu. Oválny oblúk náušnice kruhového prierezu (hr. 1,7 mm) člení drôtený uzlík; pr. 16 x 13,5 mm, v. 20 mm (tab. XIV: 29: 1).

Hrob 30 (C/2; tab. XIV)

Obdížnikovitý obrys hrobovej jamy $(175 \times 75 \mathrm{~cm})$ so zaoblenými rohmi. Kostra dospelej ženy (F, ad. II), orientovaná v línii $252^{\circ}$, leží na chrbte (hî. $100 \mathrm{~cm}$ ). Lebka nachýlená na lavý spánok, horné a dolné končatiny v osi skeletu. Konča pravého chodidla nádoba (1).

Opis nálezov

1. Hrncovitá keramická nádoba misovitého tvaru, ústie s lievikovite zrezaným okrajom, horná polovica tela dodatočne obtočená. Na podhrdlí až vydutine v štyroch prípadoch jedna alebo dve horizontálne línie a dve línie vlnoviek vyhotovené jednohrotým rydlom. Na vyklenutom dne plastický solárny motív a odtlačky drevenej podložky. V keramickej hmote jemný piesok. Kvalitný výpal, farba hnedá s ružovým odtieňom; pr. ústia $125 \mathrm{~mm}$, pr. vydutiny $114 \mathrm{~mm}$, pr. dna $65 \mathrm{~mm}$, v. $114 \mathrm{~mm}$ (tab. XIV: 30: 1).

Hrob 31 (C/2; tab. XIV)

Obdížnikovitý obrys hrobovej jamy $(212 \times 82-70 \mathrm{~cm})$ so zaoblenými rohmi. Kostra dospelého muža (M, sen.), orientovaná v línii $252^{\circ}$, leží na chrbte (hí. $125 \mathrm{~cm}$ ). Lebka nachýlená na pravý spánok, horné a dolné končatiny v osi skeletu.

Bez nálezov.

Hrob 32 (C/2; tab. XV)

Obdížnikovitý obrys hrobovej jamy $(160 \times 62$ cm) s vyklenutou dolnou koncovou stranou, zvyšné rohy pravouhlé. Kostra dospelej ženy (F, mat. II), orientovaná v línii 278, leží na chrbte (hí. $130 \mathrm{~cm}$ ). Lebka spočíva na zátylku, línia chrbtice oblúkovite prehnutá doprava, pravá horná končatina súbežná s líniou chrbtice, l’avá horná končatina a dolné končatiny v osi skeletu. Pri lavej dlani zlomok nádoby (1).

Opis nálezov

1. Zlomok z hornej časti keramickej nádoby misovitého tvaru, ústie so zaobleným okrajom, horná štvrtina tela dodatočne obtočená. Na podhrdlí a vydutine pás vlnovky, pod vydutinou horizontálna línia vyhotovená hrebeňom s tromi zubmi. V keramickej hmote hrubý piesok. Kvalitný výpal, farba tmavohnedá; pr. ústia $130 \mathrm{~mm}$, pr. vydutiny $127 \mathrm{~mm}$ (tab. XV: 32: 1).

Hrob 33 (C/2; tab. XV)

Obdížnikovitý obrys hrobovej jamy (168 x 60-78-57 cm) s vyklenutou pravou pozdlžnou stranou a zaoblenými rohmi. Kostra dospelej ženy (F, mat. II), orientovaná v línii 333, leží na chrbte (hí. $135 \mathrm{~cm}$ ). Lebka spočívajúca na záhlaví vykrútená doprava, os chrbtice a dolných končatín zalomená o $15^{\circ}$, horné končatiny súbežné s osou hornej polovice trupu. Pri l’avom spánku náušnica (1), na pravej strane temena náušnica (2), pod lebkou náušnica (3), v pravej časti panvy praslen (4), konča l’avého chodidla nádoba (5).

Opis nálezov

1. Krúžková náušnica oválneho tvaru z bronzového drôtu kruhového prierezu; pr. 14,5 x 14 mm (tab. XV: 33: 1).
2. Krúžková náušnica kruhového tvaru zo železného drôtu kruhového prierezu (hr. 2 mm); pr. 21 x 20 mm (tab. XV: 33: 2).

3. Náušnica s jednostranným dvojkónickým hrozienkovým záveskom $\mathrm{z}$ troch vencov granúl (pr. 2-3 mm, v. 3,5 mm) z bronzu. Deformovaný oblúk z drôtu kruhového prierezu (hr. 1,3 mm) člení drôtený uzlík; pr. 19 x 17 mm, v. $21 \mathrm{~mm}$ (tab. XV: 33: 3).

4. Dvojkónický keramický praslen; pr. 25-34 mm, v. 16 mm (tab. XV: 33: 4).

5. Hrncovitá keramická nádoba súdkovitého tvaru, ústie so zaobleným okrajom, hrdlo dodatočne obtočené. Na vydutine dve línie nepravidelnej vlnovky pozostávajúce $\mathrm{z}$ vpichov vyhotovených hrebeňom s piatimi zubmi. Dno mierne vyklenuté. V keramickej hmote hrubý piesok s vyšším podielom stredne vel'kých až vel'kých kamienkov vystupujúcich na povrch v dolnej časti nádoby. Výpal nižšej kvality, farba čiernohnedá; pr. ústia $93 \mathrm{~mm}$, pr. vydutiny $113 \mathrm{~mm}$, pr. dna $77 \mathrm{~mm}$, v. $122 \mathrm{~mm}$ (tab. XV: 33: 5).

Hrob 34 (B/2; tab. XVI)

Obdížnikovitý obrys hrobovej jamy $(175 \times 78 \mathrm{~cm})$ so zaoblenými rohmi. Kostra detského jedinca (inf. III), orientovaná v línii $244^{\circ}$, leží na chrbte (hí. 130 cm). Lebka vyvrátená záhlavím nahor, horné a dolné končatiny v osi skeletu. Nalavo od sánky náušnice $(1,2)$.

Opis nálezov

1. Krúžková náušnica oválneho tvaru z bronzového drôtu kruhového prierezu (hr. 1,1 mm); pr. 14,5 x 14 mm (tab. XVI: 34: 1).

2. Náušnica s chýbajúcim záveskom z bronzu. Oválny oblúk náušnice $z$ drôtu kruhového prierezu (hr. 1,2 mm) v spodnej časti ovinutý tenkým drôtikom; pr. 18 x $14 \mathrm{~mm}$, v. $22 \mathrm{~mm}$ (tab. XVI: 34: 2).

Hrob 35 (B/2; tab. XVI)

Obdížnikovitý obrys hrobovej jamy $(168 \times 72 \mathrm{~cm}) \mathrm{s}$ pravouhlými až zaoblenými rohmi. Kostra dospelej ženy (F, ad.), orientovaná v línii $243^{\circ}$, leží na chrbte (hí. $130 \mathrm{~cm}$ ). Lebka spočíva na zátylku, horné a dolné končatiny v osi skeletu. Pri l’avom spánku náušnica (1).

Opis nálezov

1. Náušnica s odpadnutým nezdobeným plechovým bubienkom (pr. $7 \mathrm{~mm}$ ) z dvoch pologúl' upevneným pútkom z bronzu. Oblúk kruhového prierezu (hr. $1,2 \mathrm{~mm}$ ) členia dva drôtené uzlíky; pr. 21 x $22 \mathrm{~mm}$, v. 30 mm (tab. XVI: 35: 1).

Hrob 36 (B/2; tab. XVII)

Obrys hrobovej jamy nebol zdokumentovaný. Kostra detského jedinca (inf. II), orientovaná v línii $253^{\circ}$, ležala pôvodne na chrbte (hí. $90 \mathrm{~cm}$ ). Zo skeletu zachovaná iba fragmentarizovaná lebka, presunutá sánka a súbežne uložené horné končatiny. Zvyšné kosti strávené.

Bez nálezov.

Hrob 37 (B/2; tab. XVI)

Lichobežníkovitý obrys hrobovej jamy $(156$ x 55-70 cm) so zaoblenými rohmi. Kostra detského jedinca (inf. III), orientovaná v línii $265^{\circ}$, leží na chrbte (hí. $120 \mathrm{~cm}$ ). Lebka spočíva na zátylku, l’avé predlaktie smeruje do panvy, pravá horná končatina a dolné končatiny v osi skeletu. V strede pása pracka (1), pri lavom chodidle nádoba (2). 


\section{Opis nálezov}

1. Oválna pracka zo železnej tyčinky kruhového prierezu (pr. 3 mm) s jazýčkom; pr. 19 x 17 mm (tab. XVI: 37: 1).

2. Hrncovitá keramická nádoba misovitého tvaru, ústie s kuželovito zrezaným okrajom, horná tretina tela dodatočne obtočená. Na podhrdlí až vydutine horizontálna línia a dve línie vlnoviek vyhotovené jednohrotým rydlom. Na mierne vyklenutom dne v obvodovom prstenci nízky reliéf kruhu s odtlačkami drevenej podložky a obilných zrniek. V keramickej hmote jemný piesok. Kvalitný výpal, farba hnedá; pr. ústia 158 mm, pr. vydutiny 152 mm, pr. dna 80 mm, v. 140 mm (tab. XVI: 37: 2).

Hrob 38 (B/2; tab. XVII)

Lichobežníkovitý obrys hrobovej jamy $(158$ x 75-60 cm) so zaoblenými rohmi. Kostra detského jedinca (inf. III), orientovaná v línii $265^{\circ}$, leží na chrbte (hí. $85 \mathrm{~cm}$ ). Lebka spočíva na zátylku, lavé i pravé predlaktie smeruje do panvy, dolné končatiny v osi skeletu.

Bez nálezov.

Hrob 39 (C/2; tab. XVII)

Obdížnikovitý obrys hrobovej jamy $(180 \times 70 \mathrm{~cm}) \mathrm{s}$ pravouhlými a zaoblenými rohmi. Kostra dospelej ženy (F, ad. II), orientovaná v línii $253^{\circ}$, leží na chrbte (hí. $120 \mathrm{~cm}$ ). Lebka spočíva na l’avom spánku, horné a dolné končatiny $\mathrm{v}$ osi skeletu.

Bez nálezov.

Hrob 40 (C/2; tab. XVII)

Obdížnikovitý obrys hrobovej jamy $(116$ x $67 \mathrm{~cm})$ so zaoblenými rohmi. Kostra detského jedinca (inf. II), orientovaná v línii $250^{\circ}$, leží na chrbte (hí. $115 \mathrm{~cm}$ ). Lebka nachýlená na pravý spánok, horné končatiny v osi skeletu, dolné končatiny strávené.

Bez nálezov.

\section{Hrob 41 (B/2; tab. XVII)}

Obrys hrobovej jamy nebol zdokumentovaný. Kostra detského jedinca (inf. II), orientovaná v línii $250^{\circ}$, leží na chrbte (hí. $80 \mathrm{~cm}$ ). Lebka spočíva na zátylku, ramená horných končatín a dolné končatiny v osi skeletu, kosti oboch predlaktí strávené.

Bez nálezov.

\section{Hrob 42 (B/2; tab. XVII)}

Obrys hrobovej jamy nebol zdokumentovaný. Kostra detského jedinca (inf. I), orientovaná v línii $248^{\circ}$, leží na chrbte (hí. $85 \mathrm{~cm}$ ). Lebka spočíva na zátylku, horné a dolné končatiny v osi skeletu.

Bez nálezov.

Hrob 43 (C/2; tab. XVIII)

Obdížnikovitý obrys hrobovej jamy $(225$ x $83-75 \mathrm{~cm})$ so zaoblenými rohmi. Kostra dospelého muža (M, mat. II), orientovaná v línii $266^{\circ}$, leží na chrbte (hí. $140 \mathrm{~cm}$ ). Lebka spočíva na zátylku, horné a dolné končatiny v osi skeletu. Cez horný klb pravej stehennej kosti preložený nôž (1), konča pravého chodidla nádoba (2), v pravom dolnom rohu hrobu zlomky nádoby (3), vedla vajce (4). Opis nálezov

1. Železný nôž s rovným chrbtom, s čepelou zaoblenou k hrotu zo spodnej strany, zhora odsadeným tŕňom; dí. $143 \mathrm{~mm}$, š. čepele $20 \mathrm{~mm}$ (tab. XVIII: 43: 1).
2. Hrncovitá keramická nádoba súdkovitého tvaru, ústie s kuželovito zrezaným okrajom, horná tretina tela dodatočne obtočená. Na podhrdlí dva pásy vlnovky vyhotovenej jednohrotým rydlom. Dno minimálne vyklenuté. V keramickej hmote hrubý piesok. Kvalitný výpal, farba tmavohnedá; pr. ústia $96 \mathrm{~mm}$, pr. vydutiny $120 \mathrm{~mm}$, pr. dna $70 \mathrm{~mm}$, v. $148 \mathrm{~mm}$ (tab. XVIII: 43: 2).

3. Hrncovitá keramická nádoba misovitého tvaru, ústie s kuželovito zrezaným okrajom, horná polovica tela dodatočne obtočená. Na podhrdlí dva horizontálne pásy pozostávajúce z dvoch línií vyhotovených jednohrotým rydlom. Značná čast’ dna chýba. V keramickej hmote zvýšený podiel hrubého piesku. Kvalitný výpal, farba tmavohnedá; pr. ústia $180 \mathrm{~mm}$, pr. vydutiny $184 \mathrm{~mm}$, pr. dna $100 \mathrm{~mm}$, v. $160 \mathrm{~mm}$ (tab. XVIII: 43: 3).

4. Vaječné škrupiny.

Hrob 44 (C/2; tab. XIX)

Obdížnikovitý obrys hrobovej jamy $(188 \times 68-78 \mathrm{~cm})$ s pravouhlými až zaoblenými rohmi. Kostra dospelého muža (M, mat. II), orientovaná v línii $263^{\circ}$, leží na chrbte (hí. $115 \mathrm{~cm}$ ). Pôvodnú polohu fragmentarizovanej lebky nemožno určit, horné a dolné končatiny v osi skeletu. Lavé predkolenie sčasti prekryté tenkou vrstvou uhlíkov v tmavo sfarbenej zemine obdĺžnikovitého tvaru $(27 \times 7 \mathrm{~cm})$. Medzi hornými častami stehenných kostí nôž (1), pri kostiach predkolenia a konča pravého chodidla rozptýlené zlomky nádoby (2).

Opis nálezov

1. Železný nôž s rovným chrbtom, čepelou zaoblenou k hrotu zo spodnej strany, obojstranne zúženým pásikovým tŕňom; dí. 140 mm, š. čepele 17 mm (tab. XIX: 44: 1).

2. Hrncovitá keramická nádoba misovitého tvaru, ústie so zvislo zrezaným okrajom, horná tretina tela dodatočne obtočená. Na vydutine osem horizontálnych línií vyhotovených jednohrotým rydlom. Na vyklenutom dne v obvodovom prstenci nezretelné odtlačky drevenej podložky. V keramickej hmote zvýšený podiel hrubého piesku. Kvalitný výpal, farba hnedá s ružovým odtieňom; pr. ústia $185 \mathrm{~mm}$, pr. vydutiny $183 \mathrm{~mm}$, pr. dna 95 mm, v. 155 mm (tab. XIX: 44: 2).

Hrob 45 (B/2; tab. XVII)

Obdížnikovitý obrys hrobovej jamy (223 x 75-90-70 cm) s vyklenutou hornou koncovou i lavou pozdížnou stranou a zaoblenými rohmi. Kostra dospelého muža (M, ad. II), orientovaná v línii 256, leží na chrbte (hí. $120 \mathrm{~cm}$ ). Lebka vyvrátená záhlavím nahor, horné a dolné končatiny $\mathrm{v}$ osi skeletu.

Bez nálezov.

Hrob 46 (C/2; tab. XIX)

Obrys hrobovej jamy nebol zdokumentovaný. Kostra detského jedinca (inf. III), orientovaná v línii 243, leží na chrbte (hí. $100 \mathrm{~cm}$ ). Lebka spočíva na zátylku, horné a dolné končatiny v osi skeletu. Konča pravého chodidla nádoba (1).

Opis nálezov

1. Hrncovitá keramická nádoba misovitého tvaru, ústie so zaobleným okrajom, horná tretina tela dodatočne obtočená. Na vydutine pät horizontálnych línií vyhotovených jednohrotým rydlom. Na vyklenutom 
dne v obvodovom prstenci odtlačky dvoch koncentrických kruhov. V keramickej hmote hrubý piesok. Kvalitný výpal, farba hnedá; pr. ústia $115 \mathrm{~mm}$, pr. vydutiny $112 \mathrm{~mm}$, pr. dna $60 \mathrm{~mm}$, v. $111 \mathrm{~mm}$ (tab. XIX: 46: 1).

\section{Hrob 47 (C/2; tab. XX)}

Obrys hrobovej jamy nebol zdokumentovaný. Kostra dospelej ženy (F, mat.), orientovaná v línii $243^{\circ}$, leží na chrbte (hí. $110 \mathrm{~cm})$. Lebka spočíva na pravom spánku, horné a dolné končatiny v osi skeletu. $\mathrm{V}$ dolnej časti lavého spánku náušnice (1-3), d’alšia náušnica pod lebkou.

Opis nálezov

1. Náušnica s kuželovým špirálovite zvinutým koncom (pr. 2-4,5 mm, v. $8 \mathrm{~mm}$ ) z bronzu. Oválny oblúk náušnice $\mathrm{z}$ drôtu kruhového prierezu (hr. 0,8 mm); pr. $14 \mathrm{x}$ 9 mm, 23 mm (tab. XX: 47: 1).

2. Náušnica s nezdobeným plechovým bubienkom (pr. $6,5 \mathrm{~mm}$ ) z dvoch pologúl' upevneným pútkom $\mathrm{z}$ bronzu. Oblúk náušnice kruhového prierezu (hr. 1,2 mm) členia dva drôtené uzlíky; pr. 21 x 17 mm, v. 25,5 mm (tab. XX: 47: 2).

3. Náušnica s kuželovým špirálovite zvinutým koncom (pr. 2-4 mm, v. 7,5 mm) z bronzu. Oválny oblúk náušnice $\mathrm{z}$ drôtu kruhového prierezu (hr. $1 \mathrm{~mm}$ ); pr. $12 \mathrm{x}$ $12 \mathrm{~mm}$, v. $20 \mathrm{~mm}$ (tab. XX: 47: 3).

4. Náušnica $s$ nezdobeným plechovým bubienkom (pr. $6,5 \mathrm{~mm}$ ) z dvoch pologúl' upevneným pútkom $\mathrm{z}$ bronzu. Oblúk náušnice kruhového prierezu (hr. 1,2 mm) členia dva drôtené uzlíky; pr. 21 x 20 mm, v. 28 mm (tab. XX: 47: 4).

Hrob 48 (B/2; tab. XX)

Obdížnikovitý obrys hrobovej jamy $(115$ x $47 \mathrm{~cm}) \mathrm{s}$ pravouhlými až zaoblenými rohmi. Kostra detského jedinca (inf. II), orientovaná v línii $258^{\circ}$, ležala pôvodne na chrbte (hí. $125 \mathrm{~cm}$ ). Lebka spočíva na zátylku, zvyšné časti skeletu strávené. Zhruba $10 \mathrm{~cm}$ nad dnom tenká vrstva uhlíkov v tmavo sfarbenej zemine nepravidelného pozdížneho tvaru $(48 \times 4-10 \mathrm{~cm})$. Pri pravej strane hornej čelusti koráliky (1).

Opis nálezov

1. V náhrdelníku možno postrehnút jeden kuželovitý korálik zo žltého skla; pr. 4 mm, dí. 3 mm; jeden valcovitý korálik z tmavomodrého skla; pr. $7 \mathrm{~mm}$, dí. 5,5 mm; (tab. XX: 48: 1).

\section{Hrob 49 (B/2; tab. XX)}

Obdížnikovitý obrys hrobovej jamy $(183$ x $58 \mathrm{~cm})$ s pravouhlými až zaoblenými rohmi. Kostra dospelého muža (M, mat. I), orientovaná v línii $262^{\circ}$, leží na chrbte (hí. 135 cm). Lebka nachýlená na l’avý spánok, horné a dolné končatiny v osi skeletu. $Z$ vnútornej strany pravého kolena zhluk predmetov pozostávajúci z noža (1), ociel'ky (2), úštepu (3), sekerovitej hrivny (4).

1. Železný nôž s rovným chrbtom, s čepelou zaoblenou k hrotu zo spodnej strany, obojstranne odsadeným hrotitým tŕňom; dí. 105 mm, š. čepele 16 mm (tab. XX: 49: 1).

2. Železná ociel'ka oválneho tvaru; dí. $84 \mathrm{~mm}$, š. $40 \mathrm{~mm}$ (tab. XX: 49: 2).

3. Úštep trojuholníkovitého tvaru zo silicitu; dí. $11 \mathrm{~mm}$, š. 12 mm (tab. XX: 49: 3).
4. Zlomok z koncovej časti železnej sekerovitej hrivny s prerazeným otvorom; dí. $63 \mathrm{~mm}$, š. 5-8 mm (tab. XX: 49: 4).

Hrob 50 (B/2; tab. XXI)

Obdížnikovitý obrys hrobovej jamy (192 x 54 cm) so zaoblenými rohmi. Kostra dospelého muža (M, sen.), orientovaná v línii $258^{\circ}$, leží na chrbte (hí. $130 \mathrm{~cm}$ ). Lebka na l’avom spánku, lavé a pravé predlaktie smeruje do panvy, dolné končatiny v osi skeletu. Cez l’avé predkolenie preložený nôž (1), vedla pravého chodidla ihelník s ihlou (2) a šidlo (3).

Opis nálezov

1. Železný nôž s rovným chrbtom, s čepel'ou zaoblenou k hrotu zo spodnej strany, zhora odsadeným pásikovým tŕňom; dí. 90 mm, š. čepele 16 mm (tab. XXI: 50: 1).

2/1.Ihelník z dutej kosti husi (Anser anser dom.) oválneho prierezu, dí. $90 \mathrm{~mm}$, pr. 9 x 13 mm (tab. XXI: 50: 2/1).

2/2.Ihla zo železnej tyčinky štvorhranného prierezu (pr. $3 \times 2 \mathrm{~mm}$ ) s otvorom upravenej do zahrotenej časti s kruhovitým prierezom; dí. 56 mm (tab. XXI: 50: 2/2).

3. Šidlo zo železnej tyčinky štvorhranného prierezu (hr. $3 \times 3 \mathrm{~mm}$ ) upravenej do pracovnej časti s kruhovitým prierezom (pr. $2 \mathrm{~mm}$ ); dí. $91 \mathrm{~mm}$ (tab. XXI: 50: 3).

Hrob 51 (B/2; tab. XXI)

Obdížnikovitý obrys hrobovej jamy (188 x 64 cm) s vyklenutými koncovými stranami. Kostra dospelej ženy (F, mat. I), orientovaná v línii $258^{\circ}$, leží na chrbte (hí. $140 \mathrm{~cm}$ ). Lebka spočíva na zátylku, horné a dolné končatiny v osi skeletu. Popri pravej stene hrobu pozdížny pás uhlíkov v tmavo sfarbenej zemine $(155 \times 3-4 \mathrm{~cm})$. Bez nálezov.

\section{Hrob 52 (B/2; tab. XXI)}

Obrys hrobovej jamy nebol zdokumentovaný. Kostra detského jedinca (inf. II), orientovaná v línii $256^{\circ}$, ležala na chrbte (hí. $90 \mathrm{~cm}$ ). Lebka spočíva na zátylku, horné a dolné končatiny $\mathrm{v}$ osi skeletu. V l'avej dolnej časti hrudníka nôž (1).

Opis nálezov

1. Železný nôž s rovným chrbtom, s čepelou zaoblenou k hrotu zo spodnej strany, zhora odsadeným tŕňom; dí. 95 mm, š. čepele 10 mm (tab. XXI: 52: 1).

Hrob 53 (C/2; tab. XXI)

Obdížnikovitý obrys hrobovej jamy $(197 \times 72 \mathrm{~cm})$ so zaoblenými rohmi. Kostra dospelej ženy? (F? sen.), orientovaná v línii $245^{\circ}$, leží na chrbte (hí. $90 \mathrm{~cm}$ ). Lebka spočíva na pravom spánku, horné a dolné končatiny v osi skeletu. Z vnútornej strany pravého predlaktia nôž (1).

Opis nálezov

1. Železný nôž s rovným chrbtom, s čepelou v náznakoch zaoblenou k hrotu zo spodnej strany, obojstranne odsadeným tŕňom. Na lavej strane čepele krvný žliabok (dí. 63 mm, š. 4,5 mm); dí. 98 mm, š. čepele 21 mm (tab. XXI: 53: 1).

Hrob 54 (C/2; tab. XXI)

Obrys hrobovej jamy nebol zdokumentovaný. Kostra dospelého muža? (M, mat. II), orientovaná v línii 253', leží na chrbte (hí. $120 \mathrm{~cm}$ ). Lebka nachýlená na pravý spánok, horné a dolné končatiny v osi skeletu.

Bez nálezov. 


\section{POHREBISKO}

Miestam spätým s posledným odpočinkom zosnulých bola od počiatkov ludskej civilizácie venovaná osobitá pozornost'. Z odborného hladiska k nim patria najmä pohrebiskové lokality s postrehnutelnými prejavmi rôzneho typu a kvality. Podla príslušných kritérií $\mathrm{k}$ nim patria osamotené hroby, hroby vyhĺbené v sídliskových areáloch, jedinci deponovaní v sídliskových objektoch, kostolné cintoríny a pohrebiská. Zástupcovia poslednej kategórie poskytujú najväčšie množstvo kvalitných informácií o pozemskom živote i záhrobnom prostredí pochovaných. Ich akceptáciu zvyšuje takisto nadmerná početnost' pohrebísk poskytujúcich najvyšší počet registrovaných hrobov (Hanuliak 2002, 83-87).

\section{Poloha}

Spracúvanú nekropolu tvorí 54 hrobov vyhíbených na ploche obdĺžnikovitého tvaru s rozmermi $49,5 \times 40 \mathrm{~m}$ a plochou $1980 \mathrm{~m}^{2}$. K jej umiestneniu bol zvolený takmer rovinatý úsek sformovaný prírodnými činitel'mi na východných svahoch pahorkatiny, klesajúcich pozvolne do inundačného prostredia. Túto plochu zo západnej strany oblúkovito vymedzuje vrstevnica s niveletou $139 \mathrm{~m}$. Poloha náleziska je súčasne $400 \mathrm{~m}$ vzdialená od niekdajšieho riečneho koryta s prilahlým inundačným terénom v nadmorskej výške 134 m (obr. 2).

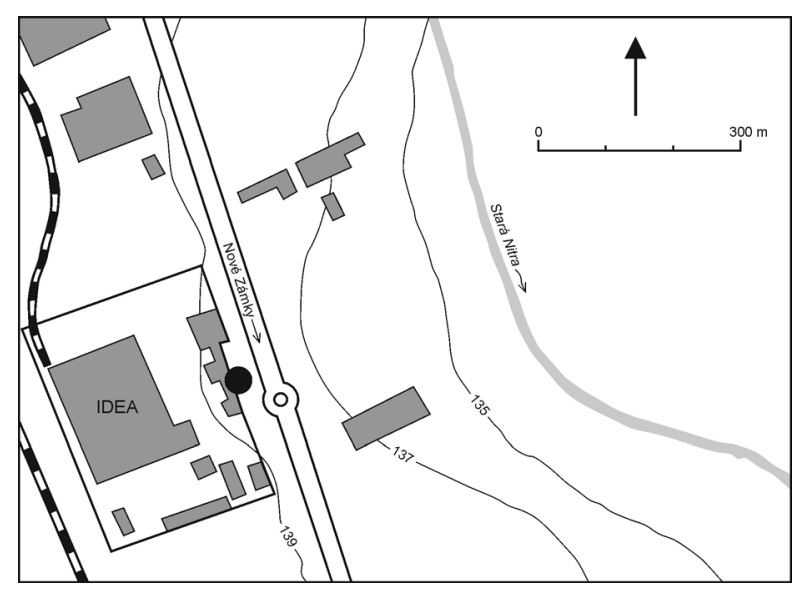

Obr. 2. Južný úsek katastra Dolných Krškán s vyznačenou polohou pohrebiska.

Podla toho je pohrebiskový areál vyvýšený o 4-5 m nad najnižšou úrovňou inundácie. Aj preto prekvapí skladba hlín v pedologickom profile lokality. Neočakávaný je najmä 50-60cm mocný sloj nadmerne kompaktnej povodňovej hliny spočívajúci pod $30 \mathrm{~cm}$ hrubou vrstvou ornice. V naplavenej vrstve sa, žial', nedali sledovat' obrysy hrobových jám s tmavšie sfarbenou zásypovou výplňou. Takáto možnost’ sa vyskytla až v rámci svetložltej podložnej úrovne zastúpenej sprašovou hlinou s premenlivým obsahom piesku.

Bez adekvátnych výsledkov prírodných vied sa nedá priblížit obdobie vzniku naplavenej vrstvy. Dostupná literatúra spája úsek vytvorenia najspodnejších úsekov tamojšieho terénu s mladotretohornými usadeninami prevrstvenými sprašou, nivnými pôdami a černozemou (Vlastivedný slovník 1977, 336).

Umiestnenie pohrebiska do opísaného prírodného prostredia nebolo akiste náhodné. Rozhodujúcu úlohu zohralo koryto rieky Nitry využívanej včasnostredovekými obyvatelmi ako zdroj vody, súčasne aj ako magický prostriedok s očistnou schopnostou využitelný voči jedincom pochovaným na pohrebisku. Poloha nekropoly v teréne zasa umožňovala vystavenie tohto prostredia celodenným účinkom slnka považovaným za d’alší magický prostriedok s ochrannou pôsobnostou (Jágerová 2001, 25; Sýkorová 1991, 170; Turčan 1993, 56).

Poloha sídliska miestnej komunity nie je známa. So značnou pravdepodobnostou bolo jej miesto vzdialené vyše 300 m od nekropoly a ležalo na okraji terasy vyvýšenej nad príležitostne zaplavovanou častou pravobrežnej inundácie.

\section{Vel'kost'}

Podl’a množstva hrobov nepatrí dolnokrškanská nekropola jednoznačne $\mathrm{k}$ vel'kým pohrebiskám. Pre reprezentantov tejto kategórie býva typické kontinuálne pochovávanie viacerých rodinných zväzkov v priebehu troch generačných cyklov. Počas nich sa mohlo na lokalite vyhíbit viac ako 60 hrobov (Hanuliak 2004a, 42). Spracúvanej lokalite chýba do tejto kvóty šest’ hrobov. Avšak tie s vel'kou pravdepodobnostou figurujú medzi 26 predpokladanými hrobmi prekrytými depóniou vykopanej zeminy. Jej nemalý objem sa navŕšil do haldy s nepravidelným pôdorysom a oddelil hroby zo západnej a východnej časti (obr. 3). Plocha skládky v rozsahu $700 \mathrm{~m}^{2}$ zaberá $35,3 \%$ z prebádaného areálu. Označená halda nebola odstránená do konca archeologického výskumu. Nachádzala sa v rámci oploteného staveniska, kde pod dohladom dozorcov pracovali väzni.

Predstavu o kompletnejšom preskúmaní celého areálu by s potrebnou presvedčivostou naplnili jeho hranice výraznejšie vzdialené od okrajových hro- 


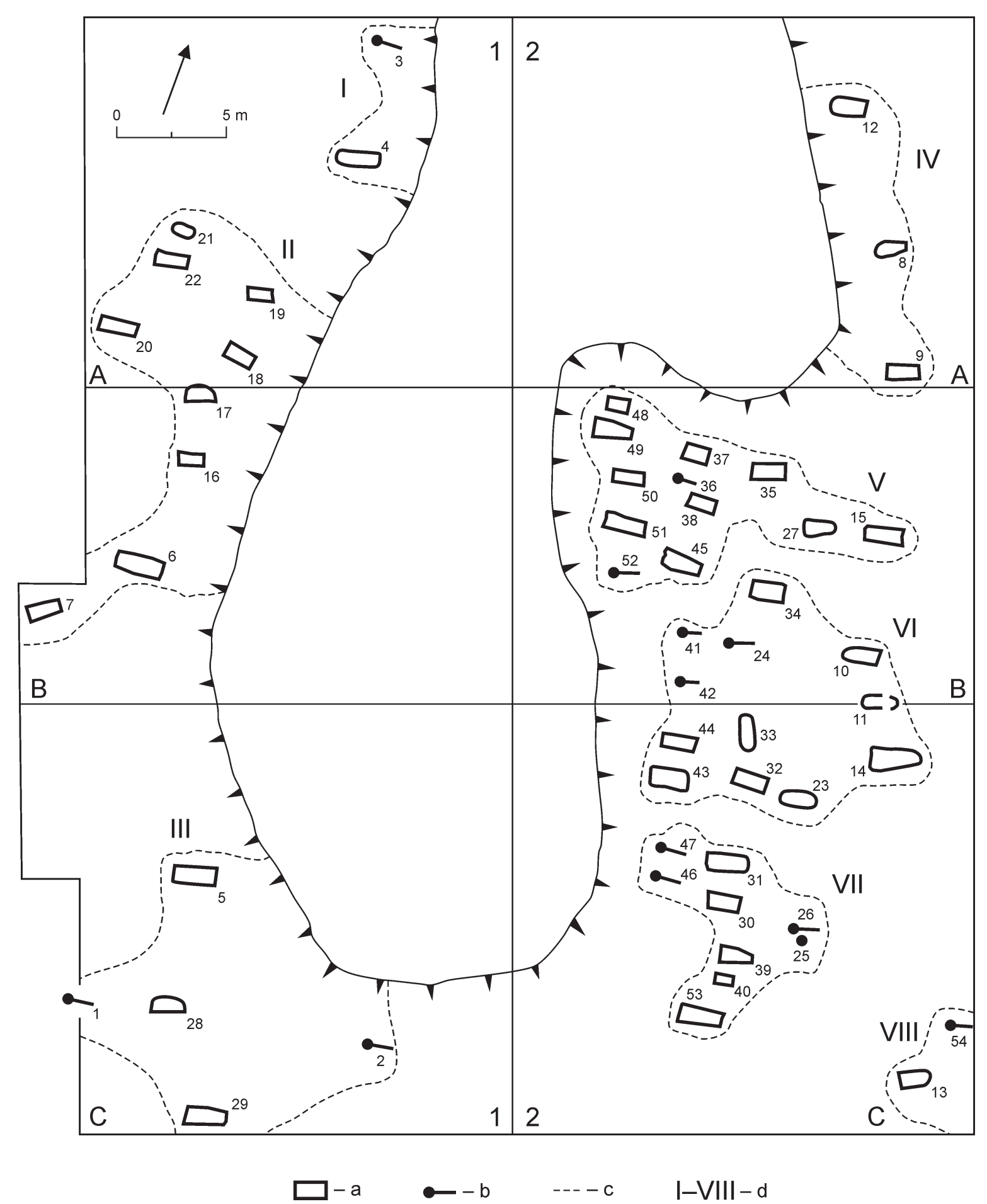

Obr. 3. Nitra-Dolné Krškany. Plán pohrebiska. Legenda: a - hrob s obrysmi hrobovej jamy; b - skelet jedinca bez obrysov hrobovej jamy; c- obvodové línie skupín hrobov; d- I-VIII - označenie skupín hrobov.

bov. Zich polohy sa dá vyčítat', že sa archeologickým výskumom zachytila tažisková čast̉ pohrebiska. Jeho skutočný rozsah v nespresnitelnom rozsahu presahoval okrajové línie pohrebiskovej plochy. Podla reálneho odhadu mohlo byt na lokalite počas 9. stor. vyhĺbených viac ako 80 hrobov.
Túto hypoteticky navýšenú hodnotu akiste zásadným spôsobom neovplyvnil aplikovaný systém odkryvu. Jeho podstata spočívala v súbežných sondách širokých 2-2,5 m oddelených blokmi intaktnej zeminy širokými $1 \mathrm{~m}$. Zdalo by sa, že pod nimi mohli zostat’ neprebádané kratšie 
hrobové jamy. Pri zvažovaní takejto možnosti sa napriek tomu ukázalo, že väčšina zástupcov tejto kategórie z najbližšieho okolia dížkou presahuje $120 \mathrm{~cm}$, pričom spriemerovaná hodnota nadobúda limit $137 \mathrm{~cm}$.

Tmavo sfarbená výplň niektorej z koncových častí hrobových jám by tak sotva zostala nepostrehnutá v žltom podložnom teréne v niektorej zo susediacich sond.

\section{Štruktúra}

K načrtnutiu vnútorného členenia spracúvaného pohrebiska bolo potrebné vykonat' dva kroky. $\mathrm{V}$ rámci prvého sa zmapovali priestorové vztahy hrobov podla vzájomnej vzdialenosti, orientácie pozdĺžnych osí hrobov a líniového priebehu koncových strán. Z týchto údajov sa vyčítala zomknutost' hrobov $\mathrm{v}$ rámci celkov s vymedzitelným obvodom. Nepravidelný tvar vyčlenených zoskupení mohla ovplyvnit najmä rôzna úroveň príbuzenských vztahov pochovaných. Užšie sociálne väzby sa v zretelnejšej podobe premietli do radového systému umiestňovania hrobových jám zloženého z troch až piatich hrobov. Na ilustráciu možno uviest' hroby 48-52, 36-38, 45 z V. pohrebiskovej skupiny, hroby 41-44 zo VI. skupiny (obr. 3). Zaznamenaný prejav sa však vyskytol aj v d’alších zhlukoch s výnimkou I. skupiny. Vol'nejšie vztahy medzi pochovanými môžu zasa súvisiet s jedincami uloženými v dvojiciach, hoci aj tie mohli neskôr prerást do viac či menej pravidelných radov. K takýmto zástupcom patria hroby 3 a 4 z I. skupiny a hroby 8,9 a 12 zo IV. skupiny. Osamotená pozícia hrobu 7 z II. skupiny, hrobu 2 z III. skupiny a hrobu 15 z V. skupiny môže signalizovat istú výnimočnost jedincov, no jej podstata sa nedá priblížit.

Podla zväčšenej vzdialenosti medzi hrobmi, nesúrodej orientácie a porušenej integrity radového usporiadania sa dali počas následného kroku odčlenit hroby patriace do inej skupiny. Tento efekt zvýraznili rôzne široké pásy s nepravidelnými líniami, $\mathrm{v}$ rámci ktorých neboli zahlbované hrobové jamy. Tieto úseky mali za úlohu oddelit’ sformované skupiny hrobov, zdôraznit porušenú integritu medzi nimi. Aj preto sa dá na nich očakávał' nekultivovaný vegetačný porast (Hanuliak 2004a, 42, 43; 2005, obr. 6-8).

Z nálezovej situácie zachytenej na celkovom pláne možno vyčítat’ typické prejavy difúzneho systému umiestňovania hrobov. Jeho aplikáciou sa zdanlivo nesúrodá pozícia hrobov zmenila na osem účelovo zomknutých zoskupení (obr. 3;
Hanuliak 2004b, 56, 57). Z výsledkov predbežných analýz vyplynie náznak vývojovej postupnosti pochovávania smerujúcej východným smerom z vyššie situovaného úseku do nižšieho s intenzívnejšie zahusteným priestorom.

Rozdiely v postrehnutej intenzite pochovávania demonštruje spriemerovaná plocha pripadajúca na jeden hrob. Tento údaj nie je dostatočne výstižný, pretože vo vel'komoravskom období známe hodnoty najčastejšie oscilujú v rozmedzí 6-10 $\mathrm{m}^{2}(\mathrm{Ma}$ rešová 1983, 5; Měřínský 1985, 9; Rejholcová 1995a, 7; Vendtová 1969, 208). Na ned’alekom pohrebisku z 10.-11. stor. v Nitre-Horných Krškanoch to bolo napríklad $8 \mathrm{~m}^{2}$ (Hanuliak/Chropovský 2019). Aj preto hodnota $24 \mathrm{~m}^{2}$ vyčíslená na celej prebádanej ploche nekropoly patrí k neobvyklým prípadom.

Už pri zbežnom pohlade pôsobí vyčíslený údaj ako nadsadený. Zdôvodnenie skutkového stavu možno $\mathrm{v}$ prvom rade získat zo sledovania hustoty hrobov vyhĺbených $\mathrm{v}$ rámci vymedzených pohrebiskových skupín. Z nich iba v V. a VII. pohrebiskovej skupine pripadne na jeden hrob $5 \mathrm{~m}^{2}$. V VI. skupine je to $8 \mathrm{~m}^{2}$, v I.-III. a VIII. skupine ide o $10-12 \mathrm{~m}^{2}$. Sledovaná hodnota eskalovala na $15 \mathrm{~m}^{2}$ a $23 \mathrm{~m}^{2}$ v III. a IV. skupine.

Opakovane zaznamenávané rozdiely v híbkach a objemoch hrobových jám, sprevádzané rozdielnou skladbou i hodnotou pohrebného inventára, odrážajú okrem sociálneho aspektu aj chronologický posun v datovaní. Podla toho sa v priestorovo vymedzených skupinách pochovávalo minimálne počas dvoch generačných cyklov.

K poddimenzovanému zahusteniu pohrebiskového areálu prispieva väčším dielom hrobmi nezaplnený priestor. Z jeho rozlohy $1280 \mathrm{~m}^{2}$, stanovenej po odrátaní segmentu $700 \mathrm{~m}^{2}$ ležiaceho pod skládkou zeminy, zaberá plocha pokrytá zoskupeniami hrobov iba 487,6 m² (38,1 \%). Znamená to, že prieluky medzi mikroareálmi majú v prevahe väčší rozsah ako bežné úzke separačné pásy na iných súvekých nekropolách. Výnimkou je V.-VII. skupina hrobov reprezentujúcich jadro nekropoly. Mikroareály sformované po jej obvode nie sú zomknuté s rovnakou intenzitou, ale iba volne rozptýlené v pohrebiskovom priestore. Výsledný obraz tak v mnohom pripomína situáciu zdokladovanú na pohrebisku z 9. stor. vo Vel'kom Grobe. Tu sa v rámci rovinatej časti terasy sformovali v staršom vel'komoravskom horizonte minimálne štyri zoskupenia hrobov rozložené $\mathrm{v}$ značných vzdialenostiach od seba. Na rozdiel od nich v svahovitom teréne zo severovýchodného úseku preskúmanej plochy nadobudlo prevahu kumulované pochovávanie späté s mladším vel'komoravským horizontom (Chropovský 1957, 190, 191). 


\section{POHREBNÝ RÍTUS}

Avizovaná schopnost̉ včasnostredovekého pohrebiskového materiálu poskytovat informácie o pozemskom živote pochovaných pôsobí zdanlivo paradoxne. Materiál zo sídliskového prostredia spätý s reálnym pozemským svetom, nedisponuje v mnohých prípadoch takýmito schopnostami pre chýbajúce aktivity premietnuté do materiálne podchytených pohrebných zvykov z predkrestanského obdobia. V pohrebiskovom fonde figurujú z nich čiastkové informácie o vztahu pozostalých k zomrelému, o postavení jedinca v rodinnom zväzku i v miestnej komunite, náboženských praktikách zameraných na ulahčenie prechodu zomrelého do záhrobia, právnom vedomí spätom s aplikáciou mechanizmov zabezpečujúcich ochranu životných istôt pozostalých (Hanuliak 2011, 136, 137).

Východiskový segment z tejto kolekcie reprezentujú zložky pohrebného rítu zlučitelné s hrobovou jamou a polohou pochovaného jedinca. Informatívnu úroveň primárnych zdrojov rozširujú poznatky o skladbe pohrebného inventára, pozícii hrobovej jamy na pohrebisku, o pohlaví i veku a zdravotnej kondícii príslušného jedinca získané analýzou skeletového materiálu.

\section{Hrobová jama}

V odbornej literatúre býva vo výraznej prevahe tvar hrobových jám zaznamenávaný v zjednodušenej podobe. Prevažuje totiž ich unifikovaná forma zastúpená nanajvýš dvomi obmenami základného pôdorysného typu, doplneného o sformované nárožia, línie stien a dna. Podla toho mali príslušníci miestnej komunity pomerne jednotnú predstavu o podobe miesta posledného odpočinku zomrelého, o jeho posmrtnom príbytku a príslušnom povrchovom označení (Kurasiński 2002, 199).

Dolnokrškanské pohrebisko k takýmto lokalitám nepatrí. Na troch zdokumentovaných pôdorysných typoch sa vyskytlo viacero odlišne stvárnených prvkov. Tie sa s rozdielnou frekvenciou zdokladovali v 41 hroboch (75,9\%) s identifikovanými obrysmi hrobových jám. Ich tvar sa, naopak, nepodarilo zaznamenat' v 13 prípadoch $(24,1 \%)$. V nich bola hrobová jama zahlbená iba v rámci tmavo sfarbeného sloja povodňovej hliny stažujúcej odlíšenie hrobového zásypu.

\section{Povrchové označenie}

Na nekropolách z 9.-10. stor. zo Slovenska chýbajú doklady po trvácnejšom označovaní hrobov. Výnimku predstavuje hrob 174/85 z kostolného cintorína $\mathrm{v}$ areáli devínskeho hradu s kolovou jamou po zvislom stĺpe umiestnenom konča chodidiel (Plachá/Hlavicová/Keller 1990, 106). Ďalšie príklady ponúka šest' hrobov preskúmaných $\mathrm{v}$ dvoch polohách z Mužle-Čenkova, kde sa stípový náhrobník vyskytol pozdíž horného či dolného obvodu hrobovej jamy (Hanuliak 2014, 686; Hanuliak/Kuzma 2015, 108, 119, tab. LXI; LXVI; LXVII; LXIX; CXII).

Ako zvyšné hroby z týchto nekropol, tak aj zo všetkých ostatných $z$ vidieckeho prostredia, boli na úrovni terénu označované iba prostým rovom navršovaným z hliny skyprenej kopaním. Pri takomto pominutelnom, ale i lahko obnovitelnom označení boli telesné zvyšky dostatočne chránené pred ich porušením počas híbenia novej hrobovej jamy. Okrem toho sa zjednodušilo dodržiavanie radového umiestňovania hrobov, ulahčilo sa nielen uloženie d’alšieho jedinca do hornej časti identickej hrobovej jamy, ale aj prípadné porušenie telesných zvyškov jedinca s pripisovanými negatívnymi schopnostami.

Hrob 25 z dolnokrškanského pohrebiska nepatrí k identickým prípadom. Rekonštrukcia nálezovej situácie naznačuje, že obrysy pôvodnej jamy zrejme neboli na bližšie nespresnenom mieste zretelne označené, kedž̌e došlo k značnému porušeniu telesných zvyškov. Kosti z nich boli druhotne zakopané do náhradnej jamy s obmedzenou plochou odkrytej počas archeologického výskumu (tab. XII: 25).

\section{Tvar}

Medzi 41 zdokumentovanými hrobovými jamami výrazne dominuje obdížnikovitý tvar (82,9 \%). Zástupcovia s lichobežníkovitým (12,2 \%) a oválnym pôdorysom (4,9\%) sú v menšine. Frekvenciu obdížnikovitého pôdorysu akiste ovplyvnila univerzálnost tvaru blízka ležiacim telám i sčasti zahíbenému kvadratickému pôdorysu obydlí stotožnitelného s podobou príbytku zomrelého (Pollex 2000, 406).

Pri vol'be lichobežníkovitého pôdorysu pragmatické aspekty unikajú ak v prípade jamy typu Lich_1 nepripustíme náznakovú blízkost so siluetou ludskej postavy premietnutou do pozdížnych strán zbiehajúcich sa od hlavy k chodidlám. Takáto možnost̉ sa, naopak, vytratí ak sa pri type Lich_2 pozdížne strany zbiehajú k hlave.

Odhalovanie príčin kopania lichobežníkovitých pôdorysov nebolo dosial' úspešné. Situáciu nezjednodušilo ani zvýšenie limitnej hranice rozdielov v šírke koncových strán viac ako $20 \mathrm{~cm}$ u dospelých a vyše $15 \mathrm{~cm}$ u detí. Vykonaním tohto kroku sa mali od seba oddelit prípady ovplyvnené náhodnými okolnostami od zvyšných so zámerne vykonanou činnostou. 
Uplatnením tohto prístupu sa na súvekých lokalitách výskyt lichobežníkovitých jám bud' nezaznamenal, vyskytol sa v hojnejšom počte (Bučany, Čakajovce) alebo v sporadickejšom zastúpení (Cífer-Pác, Trnovec nad Váhom-Horný Jatov). Medzi pochovanými prevažovali dospelí muži nad ženami (Hanuliak 2001; 2004b, 69, 70).

Dolnokrškanské pohrebisko sa od týchto údajov odlišuje. Pohrebný inventár z piatich hrobov (hroby 11, 14, 23, 37 a 38; tab. VI; VIII; XII; XVI; XVII) vykazuje rôzne hodnoty alebo chýba. Traja detskí jedinci sú častejší ako nedospelý jedinec a dospelá žena. Identické prejavy sa zaznamenali aj medzi hrobmi z poslednej štvrtiny 9. stor. odkrytými v polohe Vilmakert v Mužle-Čenkove (Hanuliak/ Kuzma 2015, 119).

Po sumarizácii všetkých podkladov dôjde k spochybneniu účasti náhodných okolností pri vzniku oboch lichobežníkovitých pôdorysných typov. Zdá sa preto, že symetrický priebeh zbiehajúcich sa pozdlžnych strán môže súvisiet’ s odlišnou výkopovou technikou pozostalých $\mathrm{v}$ rámci precízne vytýčeného obrysu budúceho hrobu. V takýchto prípadoch sa navonok prejavuje vyššia úroveň pietnej úcty pozostalých ku konkrétnym zomrelým ovplyvnená emotívnou rovinou. Akiste aj preto nemohla byt jej podstata výstižnejšie premietnutá do materiálnych zložiek pohrebných prejavov. Predmetnú interpretáciu v náznakoch podporuje umiestnenie dvoch dvojíc hrobov s lichobežníkovitým pôdorysom $\mathrm{v}$ rámci $\mathrm{V}$. pohrebiskovej skupiny (hroby 37 a 38; tab. XVI; XVII) i VI. skupiny (hroby 11 a 14; tab. VI; VIII).

Oválny pôdorys sa zaznamenal iba v hroboch 4 a 21 (tab. II; XII). Pochovaného dospelého muža a dieta navonok nič nespája. Značne odlišné sú aj ostatné sprievodné parametre bez akýchkolvek príbuzných zložiek, ktoré mohli takýto tvar ovplyvnit. Na vel'komoravských pohrebiskách zo Slovenska sú podobné prípady takisto nadmerne sporadické (Hanuliak 2004b, 69, obr. 49). Nedá sa vylúčit, že sledovaná podoba vznikla až druhotne. Môže súvisiet so snahou o úpravu náhodne vzniknutého nepravidelného pôdorysu do pravidelnej formy. Z tohto pohl'adu je zaujímavé, že sa oválny pôdorys zaznamenal aj v hrobe 21 (tab. XI). Na jeho dno bolo uložené diet’a so zámerne pokrčenými dolnými končatinami. Ich vystretá poloha nebola možná pre nedostatočne vyhĺbenú dížku hrobovej jamy.

$S$ nepresvedčivým výsledkom zasa skončilo hladanie dôvodov, ktoré sa pričinili o vyklenutie iba hornej (hroby 6, 10, 12, 15, 17 a 45) alebo dolnej koncovej strany (hroby 4, 7, 8, 21 a 51), resp. súčasne oboch strán (hroby 22, 27 a 32). Zdokumentované parametre sú natol'ko odlišné, že vylučujú jednoznačnejšiu väzbu sledovaného prvku s pohrebnými zvykmi, pohlavím a vekom zomrelých, skladbou pohrebného inventára. Zvýšenú prítomnost' takýchto prípadov v V. pohrebiskovej skupine potvrdzujú hroby 15, 27, 45 a 51 s podielom $33,3 \%$. V II. skupine sa identicky sformované typy zaznamenali v hroboch $6,17,21$ a 22 , pričom ich podiel $\mathrm{v}$ tomto mikropriestore narástol na 55, $5 \%$.

Na rozdiel od predchádzajúcej formy hrobovej jamy zastúpenej v 35,9\%, sú na pohrebisku častejšie prípady so zaoblenými nárožiami (46, 2 \%), zriedkavejšie sú, naopak, pôdorysy so zaoblenými a pravouhlými rohmi zaznamenanými na jedinom zástupcovi (17,9\%). Híbková analýza evidovaných prípadov vedie $\mathrm{k}$ presvedčeniu, že predmetné zložky môžu súvisiet’ s miestnou pedologickou skladbou, sčasti aj rozdielnou dôslednostou výkopovej činnosti vykonávanou pozostalými. Na severovýchodnom predhradí z Břeclavi-Pohanska sa v podobných prípadoch preukázal vyšší podiel piesku v podložnom teréne (Macháček a i. 2016, 28).

V nálezovej správe uvádzaný zvislý sklon stien hrobových jám sa nedá spochybnit', aj ked' sa tieto línie nesledovali $\mathrm{v}$ rámci dlhších priečnych rezov, ale iba plošne od úrovne podložného horizontu. Aj preto treba za ojedinelý prejav označit mierne zošikmenie kratších koncových strán postrehnuté nad dnom hrobu 16 (tab. VIII). Naopak, bez výhrad treba prijat informácie o rovnom dne hrobových jám bez iných postrehnutých výnimiek.

\section{Rozmery}

Ucelenú podobu hrobových jám nemožno vytvorit bez účasti zdokumentovaných dížkových, šírkových a híbkových údajov skombinovaných do plošných a objemových rozmerov. Výsledky spomenutých zástupcov poskytli čiastkové informácie k vystihnutiu ich väzby s telesnou dispozíciou zomrelých, ich sociálnym statusom.

Význam plošných údajov hrobových jám primárne priblížia dve okrajové kategórie. Do prvej patrí osem hrobov s kulminujúcimi hodnotami v rozsahu $1,6-2,7 \mathrm{~m}^{2}$. V porovnaní so šiestimi jedincami mužského a ženského pohlavia sa $\mathrm{v}$ tejto kolekcii prekvapivo vyskytli takisto dve deti. Zatial' čo sa v hrobe 17 našiel iba sklený gombík (tab. X: 17: 1) z hrobu 13 pochádza pozlátený gombík z bronzového plechu v sprievode noža, keramickej nádoby, vedra a prílohy mäsitej potravy (tab. VI: 13: 1; VII: 13: 2-4). Posledné dva typy príloh boli uložené aj do dvoch hrobov dospelých mužov a jednej ženy. V ostatných prípadoch ide o inventár s priemernými hodnotami alebo nálezy chýbajú.

$\mathrm{K}$ dvom predchádzajúcim prípadom s naznačeným precíznejším postavením jedincov sa nepripája hrob $4 \mathrm{~s}$ dospelým mužom a dietatom uloženým v hrobe 8 . K nim priložená kopija (tab. II: 4: 1) a se- 
kera (tab. IV: 8: 1) patria k najcennejším prílohám vo vtedajšom hodnotovom systéme spätým s kultom vojenskej sily (Ruttkay, A. 2002, 107, 117). Napriek tomu nadobudla plošná výmera týchto jám iba priemerné hodnoty.

Jedinci s podpriemerným statusom sa kumulujú $\mathrm{v}$ jamách s plošným rozsahom $0,5-1,1 \mathrm{~m}^{2}$. Neprekvapí preto, že polovicu zo 16 pochovaných tvorili deti, v piatich hroboch dospelých má inventár nízke hodnoty, $\mathrm{v}$ troch prípadoch zasa úplne chýba. V ostatných hroboch s priemernými hodnotami výmery sa zaznamenala rôznorodá i nadmerne nesúrodá úroveň sledovaných vztahov.

Jednoznačnejšie vyznieva v náznakoch doložená zásada, podla ktorej boli detským jedincom najmenšieho vzrastu kopané priestrannejšie jamy. Tento jav nesúvisí so sociálnou sférou, ale s praktickými okolnostami. Pri takomto riešení sa totiž pracovný priestor s podpriemernou plochou zväčšil do takej miery, ktorá ulahčila intenzívnejšie zahlbovanie hrobov do terénu (Hanuliak 2004b, 75; 2006, 267). Naopak, bez prijatelného výsledku skončilo hladanie príčin ukladania dospelých s porovnatelnými hodnotami pohrebného inventára nielen do priestranných jám (napr. hroby 14, 27, 30 a 35; tab. VIII; XIII; XIV; XVI), ale aj do nadmerne úzkych hrobov (napr. hroby 4-7, 9, 49 a 50; tab. I-V; XX; XXI). Sírka označených hrobových jám je minimálne o trojnásobok úspornejšia ako ich dížka. Tento nepomer vyvoláva otázky o prípustných možnostiach i aplikovanej technike hĺbenia jám širokých približne $50 \mathrm{~cm}$ do spriemerovanej hlibky $207 \mathrm{~cm}$.

Híbkové údaje patria $\mathrm{k}$ najčastejšie evidovaným zložkám pohrebného rítu. Spriemerovaný údaj zdokumentovaných prípadov nadobudol hodnotu $124 \mathrm{~cm}$. Jej prispením sa od seba odčlenila skupina 26 hrobov s podpriemernými, 17 hrobov s priemernými a d’alšia skupina s nadpriemernými parametrami.

Do poslednej kategórie patrí jedenást hrobov. Voči skupine s nadpriemernými plošnými rozmermi hrobových jám ubudli $\mathrm{z}$ analyzovaného súboru hroby 29, 43 a $45 \mathrm{~s}$ vedrami, náušnicou s trubičkovým záveskom. Pribudli, naopak, hroby 5, 8, 18-20 s britvou, sekerou a náušnicami s hrozienkovým záveskom. V zásade sa tak nezmenilo prepojenie híbkových údajov so všeobecne vnímaným sociálnym statusom pochovaných. K prekvapivým zjavom patrí prítomnost' až piatich detských jedincov. Voči nim tvoria dospelí oboch pohlaví menšinový diel.

Hroby z tejto kategórie chýbajú v VI. a VII. skupine. V III., V. a VII. mikropriestore bol vyhíbený vždy iba jediný zástupca. V II. skupine ich počet nezvyčajne narástol až na šest' reprezentantov. Jama dospelého muža z hrobu 6 a dospelej ženy z hrobu
20 bola pritom vyhĺbená v okrajovom úseku zoskupenia. Hroby troch detských jedincov ležali vedla seba $v$ takmer pravidelnej línii.

Počet hrobov s vyčíslenou kubatúrou sa obmedzil na 38 prípadov s hodnotami oscilujúcimi od 0,6 do $5,4 \mathrm{~m}^{3}$. Priemerný údaj s hodnotou $1,9 \mathrm{~m}^{3}$ oddeluje od seba 14 hrobov s podpriemerným, 13 hrobov s priemerným a 11 hrobov s nadpriemerným objemom. Medzi nimi je proporcionalita jedincov príslušného pohlavia a veku nepatrne pozmenená voči hĺbkovým údajom. Ubudli iba hroby 8 a 19, pribudli, naopak, hroby 43 a 45 vyskytujúce sa pôvodne $\mathrm{v}$ zostave hrobov s priemernou plošnou výmerou.

Aj pre tieto ukazovatele sa takmer nezmenil vztah objemových hodnôt $\mathrm{k}$ pochovaným jedincom a skladbe pohrebného inventára. Pri mapovaní umiestnenia takýchto zástupcov sa zistilo, že z II. a VII. skupiny nepoznáme ani jediný prípad, v I., III. a VIII. skupine ide o jediného zástupcu, v V. a VI. o dvoch, no v II. skupine boli vyhíbené štyri hroby (obr. 4: a; 13: a). V kategórii s podpriemernými a priemernými objemovými hodnotami hrobových jám nedošlo takmer k žiadnym zmenám. V prvej z nich výraznejšie dominujú detskí jedinci na úkor ženských, prevyšujúcich počtom dospelých mužov. V druhej skupine je pomer troch kategórií pochovaných vcelku vyrovnaný, aj ked' podiel mužov o málo prevyšuje dospelé ženy.

Informácie tohto druhu sú z celkového pohladu akceptovatelné. Ich prínos sa vytratí pri posudzovaní miery vypovedacích schopností odvodených zo vztahu objemových hodnôt hrobových jám k hypoteticky rekonštruovanej sociálnej pozícii konkrétnych zomrelých. V tomto prípade, podobne ako pri híbkových údajoch, nie je dostatočne ustálený priamy vztah medzi biologicko-fyzickou podstatou jedinca a hodnotovými ukazovatelmi pohrebného inventára.

\section{Vnútorná úprava}

Doklady interiérovej úpravy sa zachovali v podobe tenkej vrstvy tmavo sfarbenej zeminy s mikročasticami rozptýlených uhlíkov zaznamenaných v hroboch 4, 44, 48 a 51 (obr. 4: e). Na plánoch bol zakreslený ich plošný rozsah. Ďalšie detaily nie sú známe, pretože sa tangované miesta nesledovali $\mathrm{v}$ priečnych rezoch dôležitých $\mathrm{k}$ priblíženiu aplikovaných konštrukčných prvkov a účelovosti ich zhotovovania. Identické zvyšky patria k jednej z foriem, $\mathrm{v}$ ktorej sa zachovali doklady drevnej hmoty používanej pri interiérovej úprave hrobových jám (Frolík 2013, 97; Frolíková-Kaliszová 2014, 323).

$\mathrm{V}$ hrobe 4 išlo zrejme o doskovú podložku so zachovanými rozmermi 172 x 12-27 cm doloženú $\mathrm{v}$ prevahe pod pravou častou dospelého muža 


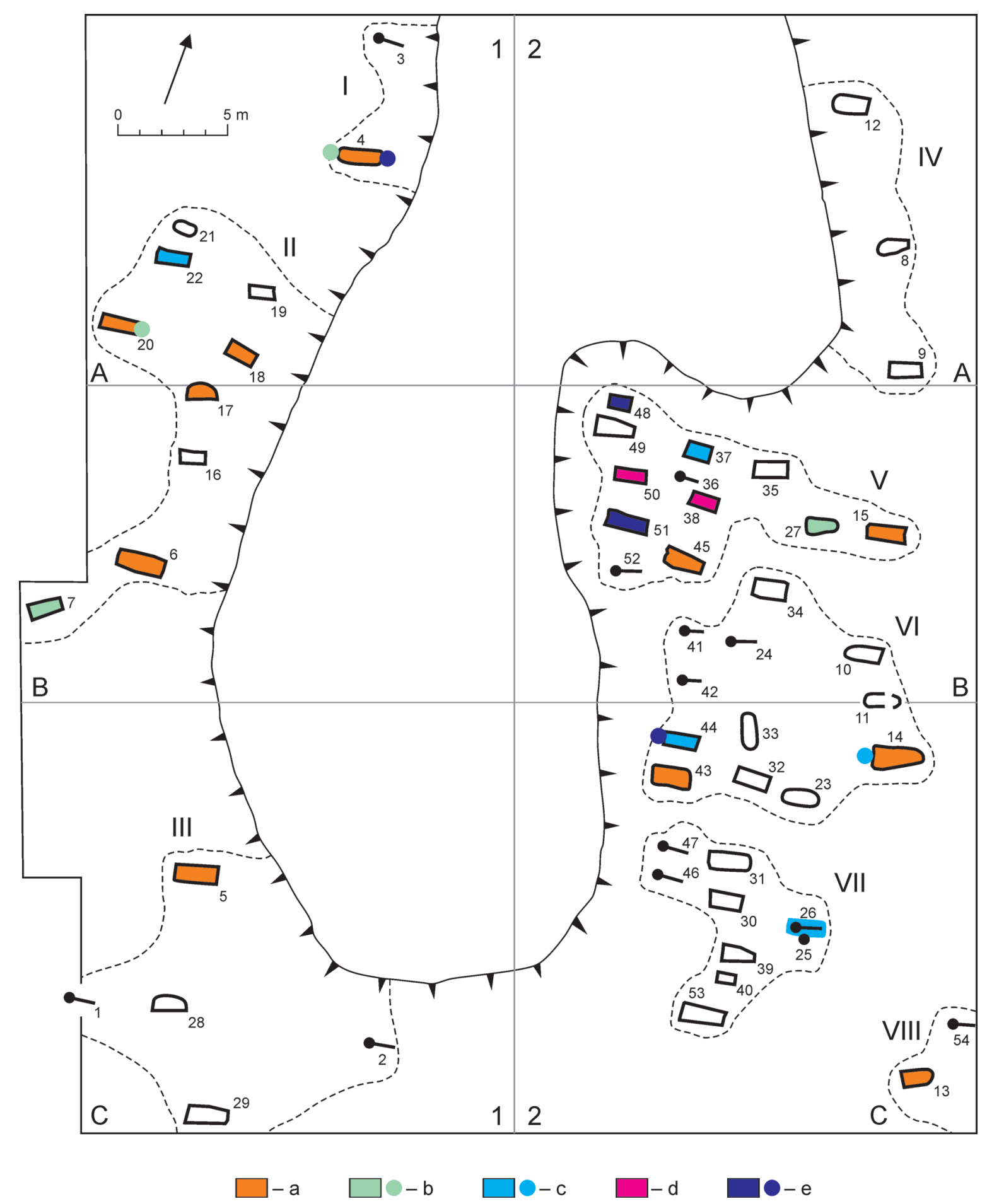

Obr. 4. Nitra-Dolné Krškany. Rozmiestnenie hrobov so sledovanými prvkami. Legenda: a - nadpriemerný objem hrobovej jamy; $\mathrm{b}$ - pravé predlaktie v panve; $\mathrm{c}$ - l’avé predlaktie v panve; $\mathrm{d}$ - obe predlaktia v panve; e - zvyšky dreva $\mathrm{z}$ úpravy hrobovej jamy.

(tab. I). Priehlbne po priečnych hranoloch, umožňujúce prepojenie viacerých dosiek do kompaktnej zostavy, sa na dne hrobu nenašli. Podla týchto informácií ide o jednoduchý typ podložky slúžiacej na prenesenie jedinca na pohrebisko a následné uloženie tela do hrobu. Nedá sa vylúčit, že tento podkladový segment mal iba izolovat pochovaného od hlineného dna hrobu a chránit pozostalých pred opakovanými dotykmi s jeho telom (Frolík 2014, 28; Macháček a i. 2016, 38; Tomková 2005, 162; porovnaj: Mazuch/Hladík/Skopal 2017, 69, 75, 290). Na súvekých nekropolách nie je tento typ úpravy sporadický. $\mathrm{Na}$ 
Slovensku ho evidujeme na 13 pohrebiskách v rámci 25 hrobov s častejšie pochovanými dospelými ženami (Hanuliak 2001).

Hrob 4 zo spracúvaného pohrebiska sa pripája k nepočetným zástupcom spätým s dospelými mužmi a hodnotnejším pohrebným inventárom. K nemu s určitostou patrí kopija, britva s d'alšími predmetmi dennej potreby. Z chronologického hladiska môže byt๋ významná mierna prevaha hrobov s doskovou podložkou v priebehu staršieho vel'komoravského horizontu (Hanuliak 2004b, 84, obr. 70-73). Zrejme aj preto bola hrobová jama vyhíbená v I. pohrebiskovej skupine zo západnej časti pohrebiska.

Na dne hrobu 51 sa pozdlž pravej strany zachoval $155 \mathrm{~cm}$ dlhý, 3-4 cm široký pás tmavo sfarbenej zeminy s mikročasticami rozptýlených uhlíkov (tab. XXI). Jeho vzhlad pripomína čast' jednoduchšieho typu postranných obkladov zomrelých známych z 38 hrobov na 13 nekropolách s kumulovaným výskytom vo Vel'kom Grobe (Chropovský 1957, 175-180, 182, 184, 188). Ked’že priečne koncové strany schránky chýbajú museli byt zvislé dosky stabilizované pomocnými konštrukčnými prvkami, ktoré sa však nezachovali. Medzi jedincami opät dominovali dospelé ženy. Detskí a nedospelí jedinci i dospelí muži tvorili v súbore menšinový diel.

Aj hrob 51 patrí dospelej žene. Pripája sa k iným reprezentantom s chýbajúcim inventárom, nanajvýš s prílohami priemernej hodnoty. Konštrukcie tohto typu sa zhotovovali počas staršieho i mladšieho vel'komoravského horizontu. Takého okolnosti mohli ovplyvnit umiestnenie pertraktovaného hrobu do V. skupiny z východnej časti nekropoly (Hanuliak 2004b, 86, 88, obr. 70, 71, 80, 81).

Z hrobu 44 zasa pochádza krátky úsek zeminy signifikantnej skladby pozdížneho tvaru s rozmermi $27 \times 7 \mathrm{~cm}$ (tab. XIX). Podla tvaru i polohy zvyškov nemožno s potrebnou istotou zrekonštruovat’ pôvodný tvar. S prípustnou dávkou tolerancie môže íst' o zvyšok dosky zachovaný z prekryvu osadeného nad pochovaným jedincom. Na problematickú existenciu takejto úpravy poukazujú chýbajúce konštrukčné prvky, ktoré by prekryv horizontálne stabilizovali nad pochovaným (Hanuliak 2004b, 84, 85; Mazuch/Hladík/Skopal 2017, 71). Identická úprava $\mathrm{s}$ väčšou plochou mohla v hrobe 48 prekrývat aj telo detského jedinca (tab. XX). Jej zvyšky o rozmeroch $48 \times 4-10 \mathrm{~cm}$ sa zdokumentovali pozdĺž pravej strany hrobovej jamy zhruba $10 \mathrm{~cm}$ nad dnom (Hanuliak 2004b, 84, 85, obr. 74: 1, 2; 75; 76).

\section{Uloženie zomrelých}

Z54 hrobov chýbajú kresbové plány iba v prvých troch prípadoch. Skeletový materiál dospelých je- dincov z nich bol značne poškodený zemnými prácami a následne odstránený z výkopu. Z informácií stavebných robotníkov sa dalo vyčítat iba približné uloženie jedincov, ktoré nevybočovalo $\mathrm{z}$ bežného rámca. Väčší problém spôsobujú detskí jedinci zo siedmich hrobov, ktorých skeletový materiál bol následkom nedostatočnej osifikácie s rozdielnou intenzitou strávený.

Spomenuté výnimky neovplyvnili naše predstavy o vtedajších zásadách uplatňovaných pri ukladaní zomrelých do hrobu. Vystretá poloha dominuje, ramená horných končatín a dolné končatiny bývajú súbežné s osou skeletu. Zvýšená frekvencia tejto polohy na pohrebisku, i v rámci d’alších súvekých nekropol, ju dovoluje označit za základnú, súčasne aj ideálnu k prechodu zomrelého do záhrobného prostredia (Hanuliak 2008a, 29, 30). Konkrétnejšie informácie o faktoroch ovplyvňujúcich polohu hlavných častí pochovaných sa dajú vyčítat z umiestnenia hláv, horných a dolných končatín i celého tela, doplneného informáciami o druhotných presunoch skeletových zvyškov.

\section{Poloha hlavy}

Zretelnejší prehl'ad o ich uložení sa získa po odčlenení desiatich prípadov s chýbajúcimi, ako aj $\mathrm{v}$ rôznom rozsahu fragmentarizovanými lebkami. $\mathrm{V}$ takto upravenej kolekcii nadobudla značnú prevahu poloha na zátylku (38,6\%). Zhruba o polovicu boli zriedkavejšie prípady hláv nachýlených na lavý alebo pravý spánok (15,9 \% a 18,2 \%). Početnost' lebiek spočívajúcich priamo na lavom či pravom spánku nie je takisto výraznejšie rozdielna (11, 4 \% a $9,1 \%)$.

Zámernú činnost vykonávanú v záujme dosiahnutia štyroch spomenutých odchýlok spochybňuje ich nepreukázatelný vzt̉ah s biologicko-fyzickými danostami jedinca, s jeho sociálnym statusom i relevantným umiestnením hrobu v rámci pohrebiskového areálu. Vo všeobecnosti sa preto pripúšta názor, že prejavy tohto druhu sú prirodzené, pretože súvisia s procesom zasypávania hrobovej jamy vykopanou zeminou (Kouřil/Tymonová 2013, 119).

Odlišná poloha sánky voči lebke presviedča, že v hroboch 10, 30 a 47 došlo $\mathrm{k}$ dislokácii hlavy $\mathrm{s}$ istým časovým odstupom po strávení svalovej hmoty (tab. V; XIV; XX). K tomu bol takisto nevyhnutný dutý priestor zachovaný $\mathrm{v}$ primárnej podobe alebo vytvorený $\mathrm{v}$ zhutnenom zásype po strávení podložky hlavy z organického materiálu. O takejto možnosti by sa dalo $s$ väčšou istotou uvažovat' v prípade nedospelej ženy a dospelého muža z hrobov 34 a 45 (tab. XVI; XVII). Ich lebky ležia vo vyvrátenej pozícii a spočívajú na temenných kostiach. Existencia oboch prípadov však nemusí byt’ 
náhodná, ak sa zohl’adní ich vzájomná vzdialenost’ obmedzená iba na $2,5 \mathrm{~m}$. K potvrdeniu opodstatnenia tohto postrehu prispieva hrob 33 vzdialený od predchádzajúcich $6 \mathrm{~m}$ (tab. XV). Lebka patriaca dospelej žene nie je síce vyvrátená temenom nahor, ale zjavne druhotne odsunutá od krčnej chrbtice tak, že sa ocitá v priečnej pozícii voči pozdížnej osi skeletu.

\section{Poloha horných končatín}

Počas vyhodnocovania polôh horných končatín nadobudla patričný význam zredukovaná šírka ich typologickej škály. Po odčlenení pochovaných s chýbajúcimi kostami predlaktí i celých horných končatín získa $\mathrm{v}$ pracovnom súbore zretelnú prevahu základná poloha $(72,5 \%) \mathrm{s}$ končatinami vystretými, prípadne v laktoch mierne ohnutými, avšak súbežnými s osou skeletu.

Tradičným doplnkom základnej polohy bývajú mierne formy odchýlok. Predlaktia pritom smerujú do pravej časti panvy (10\%; hroby 4, 7, 20 a 27; obr. 4: b; tab. I; IV; XI; XIII), lavej časti panvy $(12,5 \%$; hroby 14, 22, 26, 37 a 44; obr. 4: c; tab. VIII; XI; XII; XIV; XIX) alebo do panvy smerujú predlaktia oboch končatín (5\%; hroby 38 a 50; obr. 4: d; tab. XVII; XXI). Ako na spracúvanej nekropole, tak aj na iných súvekých pohrebiskách zo Slovenska, sa dá zdokladovat’ takmer identická skladba reprezentantov doložená s nevel'kými percentuálnymi rozdielmi.

Prítomnost' všetkých štyroch reprezentantov sa s takmer identickým percentuálnym podielom zaznamenala v rámci vel'komoravskej etapy pochovávania na čakajovskom pohrebisku (Hanuliak/ Rejholcová 1999, obr. 16). Mierne častejšiu prevahu lavého predlaktia vystriedalo v Bučanoch pravé (Hanuliak 1993, obr. 4). Zaujímavejšie vyznieva častejší výskyt miernych foriem odchýlok predlaktí u dospelých žien (Hanuliak 2004b, 103; Hanuliak/ Rejholcová 1999, obr. 19), rovnako tak aj takmer neobmedzená prevaha horných končatín súbežných s osou skeletu u detí. Neplatí to však pri každom pohrebisku. Vo Svätom Petre (Béreš 1995) je pomer oboch variantov vyrovnaný. V Nitre-Lupke (Chropovský 1962) a Kopčanoch-Hrúdoch I (Kraskovská 1965) odchýlky v uložení horných končatín výrazne dominujú u dospelých mužov. Na druhej z menovaných lokalít je taktiež početnejší variant s obomi predlaktiami v panve, hoci na väčšine pohrebísk sa zaznamenáva jeho zriedkavejší výskyt.

Zatial' čo pri základnej polohe možno jej nadmerné zastúpenie pripísat na margo optimálnej miery magického účinku v rituálnej zložke pohrebných zvykov, pri miernych odchýlkach nie je účel známy. Biologicko-fyzické danosti jedincov nie sú natol'ko vyhranené, aby sa v nich ukrýval niektorý z dôleži- tých momentov. Na dolnokrškanskom pohrebisku sa napríklad vyskytli štyria dospelí muži, pät žien a dve deti. Metrické údaje hrobových jám i skladba pohrebného inventára majú premenlivé hodnoty.

Pri hladaní príčin sa zdá byṫ signifikantnejšia poloha príslušných hrobov. V I. a II. pohrebiskovej skupine zo západnej časti pohrebiska napríklad dominovali tri hroby s pravým predlaktím voči jedinému prípadu $\mathrm{s}$ lavým predlaktím $\mathrm{v}$ panve (obr. 4: b, c). Vo východnej V., VI. a VII. skupine je to naopak. Jediný prípad pravého predlaktia stojí voči štyrom hrobom s lavým predlaktím $\mathrm{v}$ panve a d’alším dvom hrobom (38 a 50) s obomi predlaktiami v panve (obr. $4: \mathrm{b}-\mathrm{d})$. Obe tieto jamy sú vzdialené od seba iba $2,5 \mathrm{~m}$.

Zaznamenané okolnosti výskytu príslušných hrobov na pohrebisku v II., V. a VI. skupine možno vnímat’ ako indíciu spájajúcu prejavy miernych foriem odchýlok horných končatín v podobe gesta či symbolu vyjadreného pozostalými (Le Goff/Schmitt 1999, 785-787; Schmitt 2004, 88-90, 157-168). Jeho skutočný zmysel však zostáva pre nás neznámy. $\mathrm{V}$ čitatel'nej podobe sa nemusel zachovat', ak bol prepojený s princípmi predkrestanského myslenia.

Priestorová situácia zo spracúvaného pohrebiska vykazuje narastajúci posun v oblube sledovaných typov odchýlok v priebehu 9. stor. v podobnom duchu, ako to už bolo v minulosti naznačené (Hanuliak 2004b, obr. 108). Absencia niektorého zástupcu s výraznými až extrémnymi formami uloženia, reprezentovanými polohami predlaktí priečne cez brušnú dutinu či šikmo nahor cez hrudník pripúšta, že pochovávanie na lokalite nepokračuje do druhej štvrtiny 10. stor. (Hanuliak 2004b, 101-103).

\section{Poloha dolných končatín}

Uloženie dolných končatín sa nedalo stanovit u 11 detských jedincov. Ich kosti boli v úplnosti alebo čiastočne strávené. Ak k nim pripojíme sklad kostí dospelého muža označeného ako hrob 25, stúpne množstvo takýchto prípadov na 22,1 \%.

Dôležitejšie je, že v pracovnom súbore dominujú vystreté končatiny súbežné s osou skeletu zistené v 37 hroboch. Ich kolekcia nadobudne výslednú hodnotu 75,9 \% ak k nej pripojíme hrob 12 (tab. VI) $\mathrm{s}$ druhotne posunutými kostami lavej končatiny spolu s mierne odklonenou osou dolnej polovice tela z hrobov 14, 33 a 51 (tab. VIII; XV; XXI).

Zvyšnú, rozsahom takmer zanedbatelnú hodnotu, reprezentuje hrob 21. Na jeho dne sú dolné končatiny detského jedinca $\mathrm{v}$ kolenách výrazne pokrčené a preklopené do pravej strany. Kosti z predkolenia pritom ležia pod stehennými. Takáto anomália patrí k sprievodným prejavom uloženia zomrelého do výnimočnej polohy. Okrem tohto 
prípadu sa nezistili daalšie hroby, $\mathrm{v}$ ktorých by boli dolné končatiny zámerne odklonené od štandardnej pozície súbežnej s osou skeletu.

\section{Orientácia}

Opakovane overované smerovanie pozdížnych osí presviedča o značnej homogenite hodnôt zachytávajúcich orientáciu pochovaných. Najpočetnejšiu skupinu reprezentujú zástupcovia s rozmedzím $242^{\circ}-258^{\circ}(76 \%$ prípadov $)$ zlučitelným $s$ azimutom ZJZ - VSV. Až 15 spomedzi nich vykazuje hodnotu $253^{\circ}$ a $254^{\circ}$. Zistená frekvencia podporuje názor označujúci tento smer za ústrednú pohrebiskovú líniu. Udržatel’nost tohto názoru podporuje narastanie jej frekvencie z pôvodných 18,6 \% v západnej časti na 31,8 \% vo východnej časti pohrebiska.

K predchádzajúcemu azimutu sa pripájajú sporadickejší zástupcovia odklonení severným smerom ( $29,3 \%$ prípadov). Ich hodnoty oscilujúce od $259^{\circ}$ do $281^{\circ}$ patria $\mathrm{k}$ azimutu $\mathrm{Z}-\mathrm{V}$.

Zdanlivo rozšírená škála údajov s orientáciou pochovaných nenarúša avizovanú homogenitu nevyhnutnú $\mathrm{k}$ napíňaniu jej hlavného poslania. V únosnej miere zostáva zachovaný princíp skrytý v utilitárnej nevyhnutnosti nasmerovania pochovaných jedincov západným smerom do predkrestanského záhrobného prostredia umiestňovaného do miest zapadajúceho slnka (Bylina 1995, 14; Wozny 2002, 48). Vzhl’adom na kontinuálne zmeny pozície tohto astrálneho telesa na horizonte nenadobudla prvoradý význam konkrétna línia vnímaná s astronomickou presnostou. Prípustná bola širšia škála hodnôt korešpondujúcich s hlavnou pohrebiskovou osou.

$\mathrm{V}$ rámci tohto modelu našlo takisto uplatnenie citlivejšie vnímanie sklonu terénneho prostredia. Platí to najmä pre vidiecke nekropoly umiestňované prednostne $\mathrm{v}$ svahovitom teréne. Inak to nebolo ani na dolnokrškanskej nekropole s hrobmi zahlbovanými súbežne so spádnicou i napriek tomu, že povrchová úroveň nemala výraznejší sklon.

Zistené okolnosti nie je vhodné posudzovat' izolovane bez d’alších dvoch ochranných faktorov zohladňovaných $\mathrm{v}$ predkrestanskom období. Okrem vodného zdroja z blízkej rieky zohralo úlohu aj vystavenie pohrebiska celodennej pôsobnosti slnečných lúčov. Ich vzájomnými účinkami sa vytvoril potrebný mechanizmus nevyhnutný k úspešnému prechodu zomrelého z pozemského sveta do záhrobného prostredia (Hanuliak 2007, 91).

Opačné poslanie demonštrujú hroby s výrazne odklonenou orientáciou. Zo spracúvaného pohrebiska k nim patrí detský jedinec z hrobu 13 vyhĺbený v VIII. skupine (tab. VI). Jeho skelet nachádzame v línii $67^{\circ}$, ktorá je opačná voči hlavnej pohrebisko- vej línii. Zo skladby pohrebného inventára vyplývajúci vyšší sociálny status nebol zohladňovaný pri ukladaní tela do výnimočne orientovanej pozície ani pri jeho neskoršom zámernom rozrušení.

Dospelá žena z hrobu 33, zo VI. skupiny hrobov (tab. XV), bola zasa orientovaná v smere $333^{\circ}$, ktorý je nastavený priečne voči ústrednej pohrebiskovej osi. Uprednostnenie takejto možnosti môže byt výraznejšie späté s bližšie nešpecifikovanými anomáliami na skeletovom, materiáli ako s hodnotovou stránkou pohrebného inventára.

Z celkového pohladu sú azimuty orientácie na pohrebisku natol'ko jednotné, že nepripúštajú možnost' ich väzby so sezónnym pochovávaním zomrelých. Podla toho sa ich hodnoty nestotožňujú s konkrétnym jedincom, ale skupinovo s celou komunitou. Jej príslušníci si pomocou smerovania slnečnej dráhy a terénneho sklonu vytýčili optimálnu ústrednú os nekropoly. Napriek týmto okolnostiam viacerí bádatelia nad’alej hladajú nové interpretačné možnosti vytyčovania orientácie pochovaných, ktoré podla nich priliehavejšie vystihujú pomery na spracúvaných lokalitách (Frolík 2014, 111, 112; Verešč́́ková 2014, 114-121).

\section{Výnimočná poloha tela}

Vyhodnocovanie kresbových plánov preukázalo nadmerne vysoký podiel jedincov uložených v základnej pozícii na chrbte s končatinami súbežnými s osou skeletu. Odchýlky od tohto pravidla majú nielen nízku intenzitu, ale aj obmedzenú početnost'.

K najmarkantnejším prejavom odchýlok patrí detský jedinec z hrobu 21 (tab. XI). Horná čast trupu po panvovú oblast', s mierne ohnutými hornými končatinami, spočiva na chrbte. Nezvyčajná je iba poloha dolných končatín. Tie sú v kolenách výrazne pokrčené a súbežne preklopené do pravej strany. Okrem predmetov pohrebného inventára chýbajú $\mathrm{v}$ hrobe iné markantnejšie prejavy, ktoré by tohto jedinca pričlenili k rizikovým členom miestnej komunity. Neobvyklým zostáva nakoniec iba oválny pôdorys hrobovej jamy s podpriemernou dížkou.

Opísané anomálie tohto typu patria k osvedčeným praktikám aplikovaných s cielom skomplikovat zomrelým ich posmrtnú cestu do záhrobného prostredia. Nemožno prehliadnut', hoci nie objasnit', prečo frekvencia podobných prípadov kulminuje $\mathrm{u}$ detských jedincov práve $\mathrm{v}$ rámci ich strednej vekovej kategórie (Hanuliak 2006, 268).

Podla predpokladu sa na tom môže podielat’ úmrtnost detí práve z tejto skupiny dosahujúca úroveň $52 \%$. Jej príčiny korešpondujú s nevhodnou či nedostatkovou stravou, neúspešným prekonávaním príčin chorobnosti, a preto u členov komunity vyvolávali podozrenia spájané s nečistou smrtou. Okrem 
nedostatočného dohl'adu matiek pri ich opatere sa k nim neraz pridružil náhly a neočakávaný skon vyvolaný následkami skrytých úrazov alebo utopením (v. Dülmen 1999, 83-103; Gladykowska-Rzeczycka 2004, 62; Kozlowski 2004; Wozny 2002, 169).

Výrazne nižšia intenzita odlišného uloženia sa vyskytla u dospelej ženy z hrobu 20 (tab. XI). Pozdížna os skeletu je však iba mierne ohnutá, horná čast’ trupu zasa sčasti nachýlená dol’ava. Príbuzné prejavy sa postrehli aj u dospelých žien z hrobov 32 a 33 (tab. XV). Anomálie označenej intenzity nesúvisia s obrannými praktikami. Väčší podiel by sa mal pripísat patologickým, produktívno-degeneratívnym, chorobným zmenám i poraneniam, previazaným so spôsobom života, pracovnými aktivitami a fyzickou zátažou (Horáčková/Strouhal/Vargová 2004, 37-170; Sláma 1990, 126; Vondráková a i. 2011, 32-34).

\section{Porušené telo}

V poslednom decéniu nadobúdajú prevahu názory znižujúce podiel aktívnej účasti pozostalých pri porušovaní telesných zvyškov zomrelých, pri presunoch niektorých kostí. K názorovej zmene prispel rastúci záujem o túto tematickú oblast̉ doplńaný precíznejším dokumentovaním nálezových situácií i prepracovanejšou metodikou ich interpretácie. Aj vd’aka tomu sa mohli isté anomálie zlúčit s niektorými variantmi náhodných aktivít.

K nim patria účinky dekompozície vytvárajúcej po strávení svalovej hmoty, šliach a kĺbového väziva volný priestor s obmedzeným rozsahom. Ten poskytoval príležitost' k nevel'kým posunom kostí (Černý 1995, 310, 311; Dočkalová 2004, 215; Frolíková-Kaliszová 2000, 216; Prokeš 2007, 18, 19). K výraznejším zmenám malo dochádzat' $\mathrm{v}$ dutom priestore drevených konštrukcií (Dočkalová 2005, 331, 332; Frolíková-Kaliszová 2000, 216). Menší podiel prejavov sa pripisuje pôsobnosti koreňových systémov vegetačných porastov, hlodavcom i divým zvieratám (Fusek 2011, 121, 122; Hanuliak 2008b, 144) a pochovávaniu d’alších jedincov na pôvodné hrobové miesto.

Z nekropoly v Dolných Krškanoch by mohol do tejto skupiny patrit hrob 25 (tab. XII), ktorý zrejme nebol na pôvodnom, bližšie nespresnenom mieste, zretel’ne označený. Po značnom porušení telesných zvyškov dospelého muža kopaním hlbšieho hrobu boli najdôležitejšie kosti premiestnené do novej jamy vyhĺbenej na inom mieste. Jej obdížnikovitá dispozícia má plochu účelovo zmenšenú na rozmer $53 \times 33 \mathrm{~cm}$. Prejav pietnej úcty sa dá vyčítat' z uloženia dolnej čeluste prekrytej dlhými kostami z končatín, z pripojenej fragmentarizovanej lebky a hrudnej kosti. Nová pozícia tohto zhluku nebola takisto náležite označená, pretože sa $\mathrm{v}$ jeho tesnej blízkosti vyhíbil hrob $26 \mathrm{~s}$ dospelou ženou. Oba skelety bez príbuzenskej väzby sú od seba vzdialené iba $20 \mathrm{~cm}$.

Podobné prípady patria na dedinských pohrebiskách k výnimočným zjavom (Daňová/Ruttkay, M. 2011, 164), pretože narastajúca koncentrácia hrobov nepresahovala únosnú mieru. Postupným zahustovaním mikropriestorov počas dvoch až troch generačných cyklov nedochádzalo k takému prehusteniu hrobových jám, ktoré by vyústilo do ich vzájomného porušovania. Kritická situácia tohto druhu sa riešila presunom pochovávania z pôvodného mikroareálu do nového priestoru pripojeného k okraju nekropoly (Hanuliak/Rejholcová 1999, 15-17). Z čakajovského pohrebiska sú známe iba dva prípady, v ktorých bol starší hrob zničený mladším tak, ako v hrobe 25 zo spracúvanej nekropoly (Rejholcová 1995a, 10, 11).

Na iných lokalitách z vidieckeho prostredia ich prítomnost' chýba. V tomto prostredí sú, naopak, častejšie zastúpené prejavy spájané so zámernými aktivitami pozostalých (Hanuliak 2011, 137, 139; Jágerová 2001, 13-15; Pawlik 2002, 29-31; Wawrzeniuk 2002, 75-78).

Z dolnokrškanskej nekropoly patrí do tejto skupiny hrob 5 (tab. II). Vzhladom na jeho zahĺbenie do úrovne $170 \mathrm{~cm}$ dochádza $\mathrm{k}$ eliminácii úvah o možnom súvise anomálií s koreňmi vegetácie, činnostou hlodavcov alebo divých zvierat. S druhotným zásahom treba rátał najmä na základe premiestnených kostí z hrudníka a predlaktí. Ich zhluková podoba sa nedá zlúčit iba s presunmi zásypovej zeminy uvol'nenými po strávení doskového prekryvu. O jeho prítomnosti, doloženom v náznakoch aj v hrobe 12, výraznejšie v hrobe 13 (tab. VI), možno teoreticky uvažovat podla polohy keramickej nádoby a vedierka. Na druhej strane sa o takýto výsledok mohli pričinit takisto druhotné aktivity pozostalých. Spomenuté nádoby s d’alšími predmetmi súčasne oslabujú spojenie druhotného zásahu do hrobovej jamy s úmyslom jej vykradnutia (Hanuliak 2011, 134).

Opodstatnenosṫ zistených prejavov s druhotným zásahom do analyzovaného hrobu 13 sa dá takisto vyčítat z preventívne vytýčenej orientácie, nasmerovanej opačne voči ostatným reprezentantom. Jej prispením súčasne rastie presvedčenie o bližšie nešpecifikovaných skutočnostiach takej intenzity, ktorých škodlivost' nezmiernil ani v predstihu aplikovaný obranný prostriedok (Wrzesziński 2000, 179, 190, 191). Ked’že ide zhruba o 3-5-mesačné dieta, sotva možno k negatívnym danostiam pripojit’ zdedené vlohy, $\mathrm{v}$ živote nadobudnuté skúsenosti a postihy. Prijatelnejšie sú alternatívne vnímané okolnosti tzv. „nečistej smrti“. K jej prejavom patrí náhle či dlhotrvajúce bolestné skonávanie, neprirodzené a inak podozrivé úmrtie (Ariés 2000, 19; 
Jágerová 2001, 14; Wozny 2002, 169). V hrobe 13 tak nešlo o „protivampiricky“ zameranú činnost', ale o dve formy obranných zákrokov zameraných na elimináciu škodlivých schopností niektorých jedincov (Hanuliak 2011, 136-139).

\section{POHREBNÝ INVENTÁR}

Na pohrebisku v Dolných Krškanoch sa pohrebný inventár zaznamenal v 38 hroboch $(70,3 \%$ prípadov). Od tejto hodnoty možno odvodit predpoklad, že do hrobov bola priebežne ukladaná pestrejšia a početnejšia škála predmetov. Vágnost’ tejto predstavy vynikne počas komplexnej analýzy príslušných zástupcov začlenených do piatich materiálových skupín. Ich skladba bola stanovená podla spôsobu ich používania alebo nosenia $\mathrm{v}$ reálnych podmienkach pozemského sveta, sčasti pozmeneného súvekými pohrebnými zvykmi.

Výstižnejšia špecifikácia týchto momentov sa nezaobišla bez typologickej analýzy predmetov, priblíženia ich ekonomickej hodnoty, spresnenia vztahu k pochovanému i k pozostalým na základe umiestnenia $\mathrm{v}$ hrobe, posúdenia pozície hrobu $\mathrm{v}$ pohrebiskovom areáli i $\mathrm{v}$ rámci jeho mikropriestorov.

Poznatky získané konfrontáciou reálnych skutočností s vtedajšími praktikami pohrebných zvykov sa zrejme pričinili o rozdielnu frekvenciu výskytu predmetov $\mathrm{v}$ rámci tradičných materiálových skupín. Po prihliadnutí k ich podielu v skupine reprezentantov s pohrebným inventárom sú na pohrebisku najpočetnejší zástupcovia predmetov dennej potreby (21 hrobov - 35,1\%) a kultového charakteru (20 hrobov - 33,3\%), šperky sú zhruba o tretinu zriedkavejšie (13 hrobov - 21,6\%). Súčasti odevu (4 hroby $-6,6 \%$ ) a zbrane ( 2 hroby $-3,3 \%)$ korešpondujú s vtedajším vývojovým trendom, a preto sú zriedkavé až výnimočné.

\section{Šperky}

S24 exemplármi tejto kategórie, zloženej z 11 hlavných typov a ich variantov, sa stretávame v 13 hroboch. Podla toho by táto skupina tvorila medzi hrobmi s pohrebným inventárom (34,2 \%). Táto hodnota klesne na $24 \%$, ak sa do úvahy vezme podiel šperkov medzi všetkými predmetmi materiálnej kultúry (obr. 5).

Uvedená hodnota vcelku zodpovedá škále zredukovanej na šperky zdobiace hlavu - náušnice a šperky zdobiace hrdlo - náhrdelníky zložené z korálikov. Chýbajú, naopak, v danom období sporadickejšie nosené prstene alebo závesky spes-

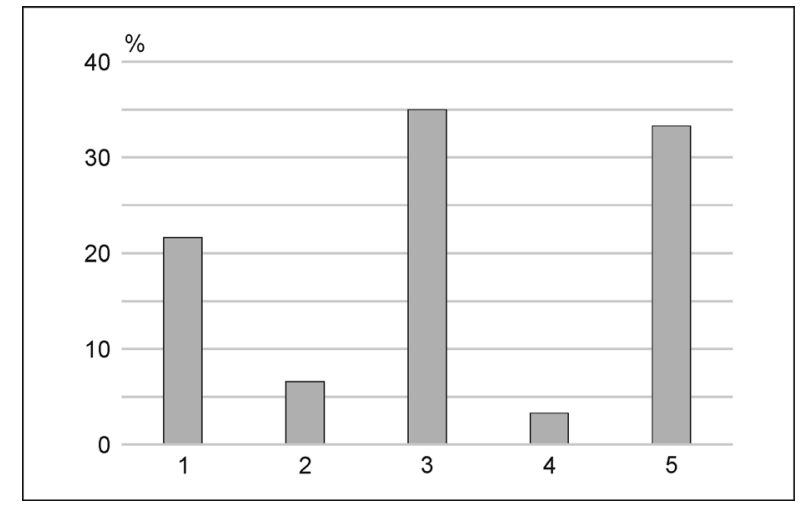

Obr. 5. Nitra-Dolné Krškany. Výskyt hlavných typov predmetov a ich variantov v materiálových skupinách. 1 -šperky; 2 - súčasti odevu; 3 - predmety dennej potreby; 4 - zbrane; 5 - predmety kultového charakteru.

trujúce náhrdelníky. Kolekcia náušníc sa dá z hl’adiska základného triedenia rozdelit na exempláre podunajského a veligradského typu doplnené zástupcami špecifického typu.

\section{Náušnice podunajského typu}

Základnú škálu zástupcov predmetnej skupiny primárne špecifikoval B. Dostál (1966, 30-33, obr. 7). V Dolných Krškanoch sa spomedzi nich objavilo pät typov (7-1, 7-3, 7-11, 7-19, 7-21) s 12 kusmi nájdenými v hroboch 23, 27, 29, 33, 34, 35 a 47 (obr. 7: $a-g)$.

\section{Typ 1 - Jednoduché krúžkové náušnice}

(obr. 6: 1)

Náušnice sa našli v hroboch 27, 33 a 34 (tab. XIII: 27: 1; XV: 33: 1, 2; XVI: 34: 1), pričom $\mathrm{v}$ hrobe 33 sa vyskytli v dvoch exemplároch. Jeden $\mathrm{z}$ nich s priemerom $21 \times 20 \mathrm{~mm}$ je výnimočne zhotovený zo železného drôtu s hrúbkou 2 mm (tab. XV: 33: 2). Našiel sa na pravej strane temena dospelej ženy stredného veku, zatial' čo sa druhá krúžková náušnica z bronzu našla pri pravom spánku.

Exempláre zo železného drôtu predstavujú na Slovensku výnimočný prvok, pretože druhý známy exemplár s priemerom $21 \mathrm{~mm}$ pochádza z hrobu 50 vyhĺbeného na pohrebisku v Nitre-pod Zoborom-Lahôdkárni. Náušnica ležala pod lebkou dospelej ženy stredného veku pochovanej v pokrčenej polohe na pravom boku (Chropovský 1978, 106, tab. X: 6). Vzhl'adom na túto skutočnost' nepôsobí náušnica zo železného drôtu natol'ko výnimočne. Aj s dospelou ženou z dolnokrškanského hrobu 33 sa mohli spájat' bližšie nespresnitelné anomálie, ktoré sa neprejavili v skladbe pohrebného inventára, ale v nepravidelnom pôdorysnom tvare hrobovej jamy 
a v odklonenej pozdĺžnej osi do kolmého smeru voči základnej pohrebiskovej línii.

Zvyšné tri exempláre patria k najčastejšie noseným náušniciam s nespojenými alebo spojenými koncami z bronzového drôtu. Ich oválny, v rôznej miere deformovaný oblúk má priemer 14,4-18 x 10,5-16 mm. Z množstva známych zástupcov možno na ilustráciu uviest’ náušnicu z hrobu 10 v Galante, z hrobov 21 a 29 v Hurbanove, hrobu $20 \mathrm{v}$ Lipovej-Ondrochove, hrobu $35 \mathrm{v}$ Michale nad Žitavou, hrobu 2/49 v Stupave-Máste, hrobu $32 \mathrm{v}$ Trnovci nad Váhom-Hornom Jatove (Hanuliak 2004b, tab. XXXV: 9-11; XXXIX: 4, 5, 17, 18; L: 2, 3; LIII: 21, 22; LXXIX: 3, 4; LXXXVIII: 8). V Dolných Krškanoch pochádzajú analyzované náušnice z hrobov dospelých žien a jedného dietata staršieho veku. Podla toho rozširujú dosial' známu škálu prípadov spájaných vo výraznej prevahe s jedincami spomenutej kategórie (Hanuliak 2004b, 154, obr. 172).

Náušnica z hrobu 34 (tab. XVI: 34: 1) je zaujímavá tým, že bola do nej v podobe závesku navlečená náušnica špecifického typu zachovaná $\mathrm{v}$ nekompletnom stave (tab. XVI: 34: 2). Analogické prípady bývajú nadmerne sporadické. K známym prípadom patria dva exempláre z hrobu 6 v Bíni-Hospodárskom dvore fary, v ktorých bol do krúžkovej náušnice navlečený d’alší jednoduchý krúžok (Holčík 1991, 90, 91, tab. 5: 6 HD).

\section{Typ 2 - Krúžkové náušnice s uzlíkmi}

(obr. 6: 2)

Náušnice pochádzajú z hrobov 23 a 27 (tab. XII: 23: 1; XIII: 27: 2). V prvom $z$ nich chýba istota o správnosti zaradenia. Náušnica je zhotovená z bronzového drôtu hrubého 1,2 mm. Jej oblúk pravidelného oválneho tvaru so zväčšeným priemerom na 20 x 15 mm sa zvyčajne vyskytuje na náušniciach podunajského typu s pripojeným záveskom. Je však možné, že pôvodne zhotovený tvar so záveskom mohol byt po jeho odpadnutí nad’alej nosený aj napriek menej nápaditej forme. Takúto možnost̉ potvrdzuje jej poloha pri lavom spánku dospelej ženy stredného veku.

V identickej polohe sa pri dospelej žene našiel aj druhý exemplár z hrobu 27 (tab. XIII: 27: 2). Ten má už pre daný typ šperkov obvyklý, mierne deformovaný oválny oblúk s priemerom 14,5 x $13 \mathrm{~mm}$. Z drôtených uzlíkov sa zachoval iba jeden. Takto zachovaný variant nebýva zriedkavý. Na ilustráciu možno uviest' hrob 19 z Bešeňova, hroby 50 a 92 z Bratislavy-Devína-Za kostolom, hrob 8 z Bratislavy-Karlovej Vsi, hrob 3 z Cífera-Pácu-Dráh, hrob 104 z Pobedima-Na laze, hrob 4 z Úlan nad Žitavou (Hanuliak 2004b, tab. II: 28; XIII: 3, 13; XV: 6; XVII: 21; LXXV: 11; LXXXV: 9; XCVII: 3).
Typ 3 - Krúžkové náušnice so zvinutým koncom (obr. 6: 3)

Dvaja zástupcovia tohto typu sa vyskytli iba v hrobe 47 (tab. XX: 47: 1, 3). Oba ležali pri dolnej časti lavého spánku dospelej ženy stredného veku. Pre exempláre je typický koniec špirálovite zvinutý do kužela. Dolnokrškanskí zástupcovia patria podla deviatich závitov $\mathrm{k}$ reprezentantom s užším a dlhším kónusom, do ktorého mohli byt zvinuté vd’aka tenšiemu bronzovému drôtu. $Z$ analogických prípadov možno pripojit nález z hrobu $1 / 84$ v Nitre-Chrenovej-Športovom areáli, z hrobu 1/91 v Kazemate JV bastiónu Nitrianskeho hradu, z hrobu 75 v Nitre-Lupke, hrobu 115 v Pobedime-Na laze, hrobu 19 v Tvrdošovciach-Halomi dombe (Hanuliak 2004b, LXI: 19; LXIII: 5, 6; LXX: 12; LXXV: 17, 18; XCIV: 2).

Zástupcov tohto typu poznáme z 23 hrobov vyhíbených na 18 lokalitách (Hanuliak 2001). Podla toho boli na území Slovenska sporadickejšie nosené detskými, nedospelými jedincami a dospelými ženami. Ich prítomnost na jednotlivých pohrebiskách býva obmedzená. Aj preto sa dá za istú výnimku označit nekropola z Čakajoviec s výskytom takýchto náušníc $\mathrm{v}$ troch hroboch. K nej treba pripojił aj Kazematu JV bastiónu Nitrianskeho hradu s dvomi exemplármi v jednom hrobe. Za zmienku stojí, že sa pertraktovaný typ šperku vyskytol v dvoch hroboch aj v Nitre pod Zoborom-Lahôdkárni, v Pobedime-Hradištiach, taktiež aj Pobedime-Na laze. S výnimkou nálezov z Nitrianskeho hradu môže zistená viac početnost' súvisiet’ s vyšším množstvom hrobov preskúmaných na týchto lokalitách (Hanuliak 2004b, 160).

\section{Typ 4 - Náušnica s trubičkovým záveskom}

(obr. 6: 4)

Jediný exemplár tohto typu pochádza z hrobu 29 (tab. XIV: 29: 1). Náušnica ležala pri lavom spánku nedospelého jedinca akiste ženského pohlavia. Spôsobom a intenzitou profilovaného bronzového plechu zvinutého do trubičky, jedným zachovaným uzlíkom z pôvodných dvoch i celkovými rozmermi sa predmetný exemplár takmer stotožňuje s najčastejšie zastúpenými variantmi umiestnenými v 26 hroboch na 21 pohrebiskách (Hanuliak 2001). Spomedzi nich možno ako príklad uviest' hrob 3 z Dolných Otrokoviec, hrob 44 z Mužle-Čenkova-Vilmakertu, hrob 1/91 z Kazematy JV bastiónu Nitrianskeho hradu s výnimočným výskytom troch exemplárov, hrob 1 z Nitrianskej Stredy, hroby 9/61 a 52 z Pobedima-Na laze, hrob 17 zo Svätého Petra (Hanuliak 2004b, tab. XXXIII: 6; LVIII: 5; LXIII: 7-9; LXXIII: 7; LXXIII: 15; LXXIV: 22; LXXX: 3).

Variantné obmeny sa iba minimálne odlišujú. K príznačným znakom patriaca granulka uzatvá- 


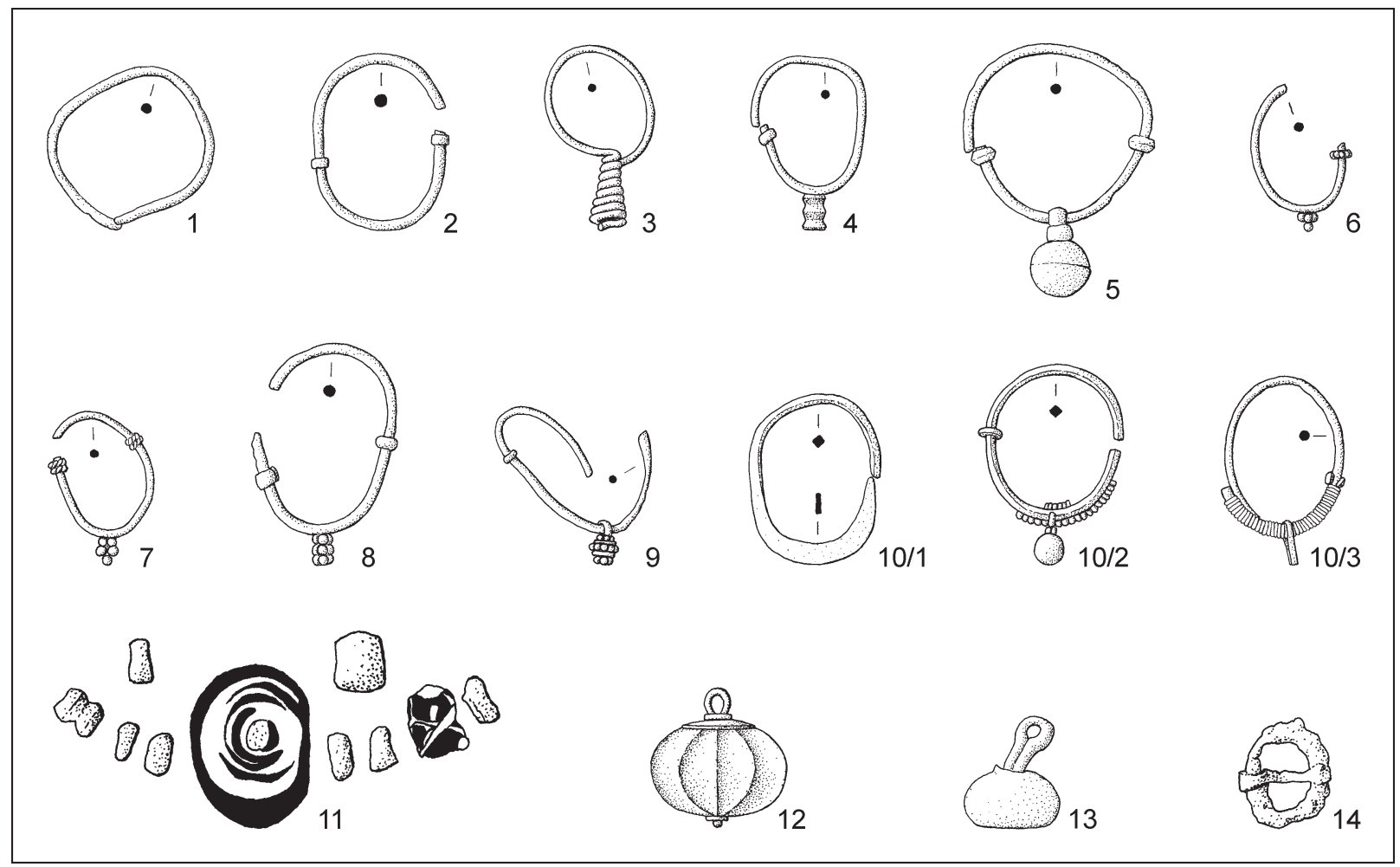

Obr. 6. Nitra-Dolné Krškany. Typologická skladba šperkov a súčastí odevu. 1-10 - predmety zdobiace hlavu; 11 - predmety zdobiace hrdlo; 12-14 - súčasti odevu.

rajúca trubičku takmer nebýva známa, pretože zvyčajne odpadla pri nosení šperku (Profantová 2015, 89).

\section{Typ 5 - Náušnice s nezdobeným bubienkom (obr. 6: 5)}

Tri exempláre predmetného typu sa získali z hrobov 35 a 47 (tab. XVI: 35: 1; XXI: 47: 2, 4). V prvom $\mathrm{z}$ nich sa náušnica našla pri lavom spánku dospelej ženy mladšieho veku. V druhom hrobe išlo takisto o oblast' lavého spánku a priestor pod lebkou ženy stredného veku.

Z 9 hrobov z iných ôsmich lokalít (Hanuliak 2001) sú známe variantné obmeny náušníc líšiacich sa v spôsobe upevnenia bubienka k oblúku, jeho členenia uzlíkmi a úpravou ukončenia. Reprezentanti z Dolných Krškán sú napohlad jednotní. Budia dojem, že ide o výrobky konkrétneho šperkárskeho majstra. Blízke až identické exempláre sa našli v 10 hroboch z ôsmich lokalít. Ich nezdobený bubienok z dvoch pologúl' je upevnený $k$ dolnému oblúku pútkom ovinutým plochým drôtikom. Oblúk člení dvojica drôtených uzlíkov. Z obmedzenej kolekcie známych prípadov bol ilustračne podchytený iba exemplár z hrobu 3 v Čataji-Nad korytom, z hrobu 3/99 v Nitre-Chrenovej-Baumax/Shell (Hanuliak 2004b, tab. XXXII: 5; LXII: 6).
Z dosial zhodnocovaných zástupcov piatich typov náušníc podunajského typu je na Slovensku vo všeobecnosti najčastejší variant jednoduchej krúžkovej náušnice (162 hrobov zo 48 lokalít) a krúžkovej náušnice $\mathrm{s}$ uzlíkmi $\mathrm{s}$ tretinovým podielom voči predchádzajúcemu. Zvyšným typom patria nanajvýš šestinové podiely. Na pohrebisku v Dolných Krškanoch nie je táto proporcionalita dodržaná. Prevaha jednoduchých krúžkových náušníc a zástupcov s nezdobeným bubienkom nad ostatnými typmi je zanedbatel'ná a sotva zdôvodnitel'ná.

Presvedčivejšie vyznieva zistenie, podla ktorého spracúvaní zástupcovia nie sú chronologicky citliví. Prvotný výskyt starších predlôh, známy už v období avarského kaganátu, býva s premenlivou frekvenciou doložený v staršom i mladšom vel'komoravskom horizonte (Čilinská 1975, 64, 76, 77, obr. 1, 12; Štefanovičová 1995, 30; Ungerman 2007, 73-87; Zábojník 2009, 56, 60, 61). Podla toho si autochtónni obyvatelia oblúbili niektoré typy náušníc zhotovovaných šperkárskymi majstrami, ktorí sa po rozpade avarského kaganátu presunuli do vel'komoravského prostredia (Štefanovičová 1995, 94).

Z porovnávaných metrických údajov hrobových jám, chýbajúcej vnútornej úpravy drevom, absentujúceho pohrebného inventára, resp. s nanajvýs sporadickým podielom jeho zložiek nízkej ekonomickej hodnoty sa dá vyčítat', že sa šperky spájajú 


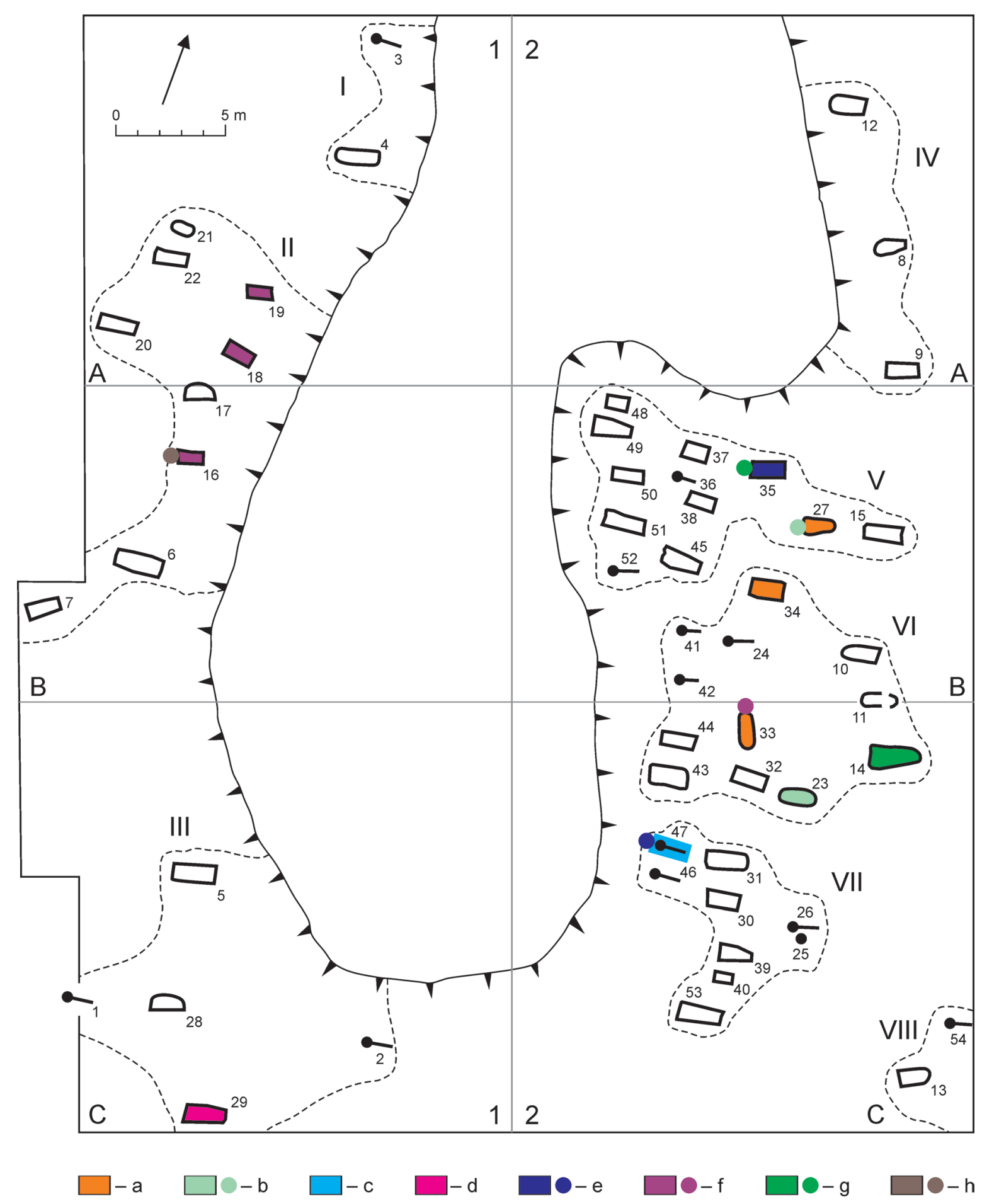

Obr. 7. Nitra-Dolné Krškany. Rozmiestnenie hrobov so šperkami. Legenda: a - náušnica (typ 1); b - náušnica (typ 2); c náušnica (typ 3); d - náušnica (typ 4 ); e - náušnica (typ 5); f - náušnice (typ 6-9); g - náušnice (typ 10); h - koráliky (typ 11).

s príslušníkmi z nižšej vrstvy vel'komoravskej society. U reprezentantov z Dolných Krškán chýbal napríklad iný sprievodný inventár v hroboch 29, 34, 35 a 47. Keramická nádoba bola uložená do hrobov 23 a 27 (tab. XII: 23: 2; XIII: 27: 5). Jej prítomnost' v hrobe 27 doplnili náušnice, nôž a praslen (tab.
XIII: 27: 1-4), uložené takisto do hrobu 33 s nádobou (tab. XV: 1-5). V tomto prípade sa nízka hodnota príloh nezvýšila ani napriek tomu, že sa v hrobe okrem dvoch krúžkových náušníc našla aj bronzová náušnica s dvojkónickým hrozienkovým záveskom (tab. XV: 3). 
Dosial' uvádzané skutočnosti nepripúštajú možnost' označit za lepšie situovaných príslušníkov nízkej vrstvy miestnej komunity ani pochovaných s náušnicou s trubičkovým záveskom alebo s nezdobeným bubienkom. Sociálnu zomknutost' nositelov náušníc podunajského pôvodu demonštruje pozícia príslušných hrobov obmedzená na východnú čast’ nekropoly s dominantným zastúpením v VI. pohrebiskovej skupine. Prítomnost' hrobov v susediacej V. a VII. skupine je nižšia (obr. 7: a-e).

Menej čitatel'né výzdobné prvky zastierajú okolnosti vzniku náušníc s trubičkovým záveskom, ktoré sa v dôležitých detailoch nestotožňujú s pôvodnými predlohami z neskoroavarského prostredia (Čilinská 1975, 72-74, obr. 1, 12; Zábojník 2009, 59). Napriek tomu sa pripúšta ich výraznejšie zastúpenie už v staršom vel'komoravskom horizonte (Hrubý 1955, 227, 228; Klanica 1985, 530; Měřínský 1985, 95). Zúzemia historickej Nitry patria k starším zástupcom tri exempláre z hrobu 1/91 z Kazematy JV bastiónu Nitrianskeho hradu. Tvoria súčast' významnej kolekcie doplnenej dvomi náušnicami s valcovitým filigránovým príveskom a dvomi náušnicami so zvinutým koncom (Bednár 1998, obr. 6: 2, 3, 5-9), čím sa potvrdzuje súvekost’ všetkých troch typov. Pretrvávanie používania náušníc s trubičkovým záveskom minimálne do prvej štvrtiny 10. stor. preukazuje exemplár z hrobu $16 \mathrm{z}$ nitrianskej mestskej tržnice a z hrobu 21 v Nitre-Horných Krškanoch (Bednár/Fottová 2003, 306, obr. 5; Hanuliak/ Chropovský 2019, 117, tab. IV: 21: 1).

\section{Náušnice veligradského typu}

Základnú škálu predmetnej skupiny primárne špecifikoval B. Dostál (1966, 35-44, obr. 8-10). Štyri typy náušníc tejto kolekcie (typ 8-2, 8-3, 8-4, 8-6) sa získali z dolnokrškanských hrobov 16, 18, 19 a 33 (obr. 7: f).

Typ 6 - Náušnica s trojbokým záveskom zloženým z jedného venca granúl

(obr. 6: 6)

Exemplár pochádza iba z hrobu 19 (tab. XI: 19: 1). Vyhotovený je zo striebra. Z pôvodných dvoch uzlíkov zo šikmo presekávaného drôtika sa zachoval iba jeden. Závesok pozostáva $\mathrm{z}$ troch horizontálne spojených granúl ukončených spodnou granulkou.

Typ 7 - Náušnice s dvojbokým záveskom zloženým $z$ dvoch vencov granúl

(obr. 6: 7)

Zástupcovia uvedenej formy pochádzajú z hrobu 18 (tab. X: 18: 1, 2). Ide o dva kusy zhotovené zo striebra. Ich oválny oblúk členia dve dvojice uzlíkov zo šikmo presekávaného drôtika. Závesok pozostáva z dvoch vertikálne napojených dvojíc granúl ukončených spodnou granulkou.

Typ 8 - Náušnice trojbokým záveskom zloženým $z$ troch vencov granúl

(obr. 6: 8)

Exempláre z hrobu 16 sú v oboch prípadoch vyhotovené z pozláteného medeného materiálu. Na zachovanej náušnici členia oválny oblúk prosté drôtené uzlíky (tab. VIII: 16: 2). Závesok pozostáva $z$ troch vertikálne napojených trojíc granúl. Z druhého exemplára akiste identického typu sa zachovala iba čast’ oblúka s jedným uzlíkom (tab. VIII: 16: 3).

U náušníc byzantského typu troch rozdielnych foriem sa vyskytlo niekol'ko blízkych i v rôznej miere odlišných prvkov. $Z$ nich možno uviest' oválny oblúk členený prostými drôtenými uzlíkmi, jedným až dvomi uzlíkmi zo šikmo presekávaného drôtu. Tri náušnice sú zhotovené zo striebra, d’alšie dve z pozlátenej medi. Tieto šperky zdobiace hlavu pochádzajú výlučne z hrobov detských jedincov stredného, resp. staršieho veku. Podla umiestnenia po oboch stranách čela ležali náušnice $\mathrm{v}$ hroboch 18 a 19 v primárnej pozícii. V hrobe 16 ide naproti tomu o druhotnú polohu, ked’že sa celý i poškodením neúplný zástupca našiel v mieste, kde pôvodne spočivali predkolenia zomrelého.

O vyššej pozícii pochovaných v miestnej komunite informujú nadpriemerné híbkové a objemové údaje hrobových jám. V podobnom rozsahu presvedčivá schopnoste indikácie zjavne chýba sprievodných nálezom. Vyššiu ekonomickú hodnotu možno pripísat iba vedru umiestnenému v hrobe 18 (tab. X: 18: 4). Pri mapovaní príbuzenských väzieb nadobúda dôležitost' líniové zoradenie všetkých troch hrobov a ich umiestnenie obmedzené iba na II. skupinu zo západnej časti nekropoly (obr. 7: f).

Očakávania precíznejších datovacích schopností vyhranených typov náušníc sa nenaplnili. Sprievodnému inventáru totiž chýba potrebná kvalita. V hrobe 19 nálezy absentujú, z hrobu 16 pochádza náhrdelník, v hrobe 18 sa našiel nôž a vedro. Konkrétnejšie informácie poskytujú azda iba najčastejšie nachádzané náušnice s drôtenými uzlíkmi a záveskom z jediného venca granúl nájdené na Slovensku v 11 hroboch na 10 lokalitách (Hanuliak 2001). V súlade so sprievodnými okolnostami bol spomedzi nich do staršieho vel'komoravského horizontu zaradený hrob 5 z Ipel'ského Sokolca, hrob 100 z Vel'kého Grobu (Hanuliak 2004b, tab. XLI: 6; CII: 5, 6). Dôležitý je takisto hrob 4 z Bratislavy-Devína-Za kostolom, pretože sa $\mathrm{v}$ ňom súčasne vyskytla 
náušnica s príveskom zloženým $\mathrm{z}$ dvoch vencov granúl (Hanuliak 2004b, tab. XII: 1, 2).

Do mladšieho horizontu bol zaradený hrob 19 z Bešeňova-Sírvölgy, hrob 166/85 z Bratislavy-Devína-Za kostolom, hrob 360 z Trnovca nad Váhom-Horného Jatova a hrob 1 zo Želiezoviec (Hanuliak 2004b, tab. II: 21; VII: 13; XC: 23; CIX: 2). Pre lokalitu z Dolných Krškán má význam hrob 292 z Čakajoviec a hrob 1/61 z Nitry-Zobora-Dražovská cesta (Hanuliak 2004b, tab. XXI: 14, 17; LXIV: 5), pretože patria takisto do mladšieho horizontu. Podla týchto zistení nemusí byt ani archaicky pôsobiaci jednoduchý tvar náušníc jednoznačne považovaný za šperk používaný prednostne $\mathrm{v}$ staršom časovom úseku.

S výskytom náušníc s príveskom $\mathrm{z}$ dvoch až troch vencov granúl sa na Slovensku takisto stretávame $\mathrm{v}$ staršom i mladšom horizonte. Na mohylovom pohrebisku v Skalici sa náušnice daného typu s rovnako šikmo presekávanými drôtenými uzlíkmi našli v hrobe $2 \mathrm{z}$ mohyly $10, \mathrm{v}$ hrobe $1 \mathrm{z}$ mohyly 3 . V. Budinský-Krička (1959, 148, obr. 28: 2, 3) ich spája s mladším vel'komoravským horizontom.

Typ 9-Náušnica s dvojkónickým záveskom zloženým $z$ troch vencov granúl

(obr. 6: 9)

Náušnica sa našla v hrobe 33 (tab. XV: 33: 3). Vyhotovená je z bronzu. Jej deformovaný oblúk člení jediný drôtený uzlík. O dvojkónický tvar závesku sa pričinil širší stredný veniec zložený z piatich granúl, zatial čo horný a dolný tvorí trojica granúl.

Takáto náušnica sa našla pod lebkou dospelejženy stredného veku. Napriek nespornej väzbe pertraktovanej náušnice s predchádzajúcimi exemplármi veligradského typu vykazuje exemplár užšiu väzbu $\mathrm{k}$ nálezom podunajskej proveniencie. Naznačuje to aj k výrobe použitý bronz, spoločný výskyt náušnice s dvomi jednoduchými krúžkovými náušnicami $\mathrm{z}$ bronzu a železa, väzba $\mathrm{k}$ dospelej žene stredného veku -niek detskému jedincovi a umiestnenie hrobu 33 vo východnej - nie v západnej časti nekropoly.

\section{Typ 10/1-10/3 - Náušnice špecifického typu}

(obr. 6: 10/1-10/3)

K dosial zhodnocovaným náušniciam z dvoch skupín neboli z viacerých príčin pripojené tri exempláre z hrobu 14 a 34 (obr. 7: g). V druhom z nich ide o bronzovú náušnicu, ktorej oblúk je súvisle ovinutý tenkým drôtikom (typ 10/3; tab. XVI: 34: 2). $\mathrm{V}$ jeho strede sa zachovalo pútko $\mathrm{z}$ odpadnutého závesku. Z opisu vyplynulo, že sa tento exemplár nezachoval $\mathrm{v}$ pôvodnom tvare. $\mathrm{S}$ patričnou dávkou rezervy možno nájdenému torzu pripojit dve náušnice z hrobu 1 v Tvrdošovciach-Kökép. Obe sa našli po stranách lebky dospelej ženy uloženej do lichobežníkovitej hrobovej jamy. Spodný oblúk náušníc oddelený drôtenými uzlíkmi bol ovinutý tenkým drôtom. Súdkovitý závesok zo skla, zovretý tenkými krúžkami, bol upevnený drôteným pútkom (Točík 1992, 133, 134, obr. 81: 2, 3).

Výskyt náušníc predmetnej formy je typický pre úsek neskorého stupňa avarského kaganátu (Čilinská 1975, 78, 79, obr. 1; 12; Zábojník 2009, 60, obr. 25). Ovinutie spodného oblúka tenkým drôtom však chýba. Náušnice z Dolných Krškán a Tvrdošoviec tak poskytujú svedectvo o možnom sporadickom pretrvávaní staršieho typu náušníc $\mathrm{v}$ modifikovanej podobe aj vo vel'komoravskom nálezovom prostredí. Dolnokrškanský zástupca nebol ani po poškodení vyradený z obehu, a zachované torzo sa druhotne využilo v podobe závesku jednoduchej krúžkovej náušnice zdobiacej lavú stranu hlavy dietata staršieho veku.

Problematickejší výsledok poskytuje snaha o rekonštrukciu pôvodného vzhladu druhej náušnice z hrobu 14 (typ 10/2; tab. VII: 14: 2). Jej kruhovitý oblúk zo štvorhranného strieborného drôtu bol predelený jednoduchým drôteným uzlíkom. K jeho spodnej časti pokrytej zvyškami granulácie bol pútkom pripojený liaty bubienok $\mathrm{s}$ priemerom $3 \mathrm{~mm}$. Z typologickej zostavy zverejnenej B. Dostálom (1966, obr. 7; 8) sa s nájdeným zástupcom nestotožňuje ani jeden. Iba s nadmernou dávkou predstavivosti môže mat' $k$ náušnici blízko exemplár nájdený v hrobe 1 z mohyly 8 skalického mohylníka, aj ked’ jeho spodný oblúk nepokrýva granulácia, ale filigán (Budinský-Krička 1959, 135, obr. 28: 7).

Oválny oblúk prvej náušnice z hrobu 14 (typ 10/1; tab. VII: 14: 1) je takisto vyhotovený zo štvorhranného strieborného drôtu, ktorý bol v spodnej časti mierne roztepaný do šírky $2,5 \mathrm{~mm}$. Ani k tejto náušnici nie sú zo Slovenska známe bližšie analógie. Nie je preto isté či ide o nedokončený, alebo hotový produkt výnimočného tvaru s odpadnutými identifikačnými znakmi. Spodný oblúk nie je totiž upravený do takej šírky, pre ktorú by sa mohol považovat’ za lunicu zaznamenanú na zvláštnych typoch náušníc zo Želoviec (Čilinská 1975, obr. 11: 7, 9).

Obe náušnice špecifického tvaru sa v hrobe 14 našli v strede čela a na lavom temene. Podla toho boli akiste nosené ako plnohodnotný šperk aj napriek možnému nekompletne zachovanému stavu. Ich vyššia ekonomická hodnota vyjadrená použitým striebrom korešponduje s nadpriemernou pozíciou dospelej ženy v miestnej komunite. Jej úroveň sa dá takisto odvodit z hrobovej jamy s najväčšími plošnými, híbkovými a objemovými hodnotami, ktorej pôdorys bol zámerne upravený do lichobežníkovitej podoby.

Ukázalo sa tak, že reálnu hodnotu oboch náušníc neznižuje ich možný nekompletný stav. Rovnako sa 
dá vnímat aj druhotne využitý poškodený exemplár z hrobu 34. V komunitách s celkove nízkym spoločenským postavením $\mathrm{z}$ vidieckeho prostredia nejde o zriedkavé prípady. Tamojší obyvatelia bez priameho vztahu s výrobcami šperkov dlhodobejšie využívali aj poškodené kusy (Galuška 1996, 99), čím sa enormne predlžuje časová etapa plynúca od ich zhotovenia po uloženie do hrobu. Na tento moment v latentnej podobe poukazujú polohy tangovaných hrobov 14 a 34 (obr. 7: g). Inak by neboli bezdôvodne vyhíbené v VI. skupine vo východnom úseku nekropoly, v ktorom sa častejšie objavujú prejavy z mladšieho vel'komoravského horizontu.

\section{Typ 11 - Koráliky}

(obr. 6: 11)

Ďalším zástupcom z nadmerne obmedzenej škály šperkov sú koráliky pochádzajúce z hrobu 16 a 48 (obr. 7: h). Ich typová škála je napriek tomu širšia, pretože ide o náhrdelníky zložené z viacerých typov korálikov.

Z tohto pohladu je významnejšia kolekcia z hrobu 16 (tab. VIII: 16: 1), pretože pozostáva z 29 korálikov rôzneho tvaru a sklenej hmoty rozdielnej farebnosti. Najvýznamnejší je spomedzi nich sploštený gul'ovitý korálik kobaltovomodrej farby. Jeho povrch zdobia tri plastické očká kuželovitého tvaru ukončené žltou bodkou, dotvorené postupným natavovaním vrstiev z tmavomodrého a bieleho skla. Opísaný exemplár výnimočného vzhl’adu sa takisto našiel v hrobe 106/AZ zo Starého Města-Na valách (Hrubý 1955, 379, tab. 37: 11). Bližšie analógie k obom korálikom nenachádzame vo včasnostredovekom prostredí, ale u korálikov s rôznofarebnými očkami rozšírenými v staršej a mladšej dobe železnej. Takúto možnost' naznačil už $V$. Hrubý $(1955,254)$. Podla $N$. Venclovej $(2005,36)$ patrí tento typ s analogicky zvrstvenými očkami na včasnohistorickom európskom území k početnejšie zastúpeným korálikom. Ich chronológii, magickému významu s ochrannými účinkami pre jedincov ženského pohlavia rôzneho veku a ich hodnotovej stránke sa venoval M. Horňák (2006, 37-41). Súčasne treba priznat', že koráliky s kuželovito zvrstvenými očkami nie sú na včasnohistorickom Slovensku časté.

Popri dominujúcich sploštených gulovitých a prstencových exemplároch s hladkými farebnými očkami z horizontu HD-LA sa opisovaná súčast’ plastického dekóru objavila prednostne na cievkovitých, resp. maskovitých korálikoch získaných napríklad z Liptovskej Mary a Mane (Březinová 2018, 23, tab. III: 8; XLIII: 2, 3). Pochované dieta z dolnokrškanského hrobu 16 patrí navyše k lepšie situovaným členom miestnej komunity. Prezrádza to aj náušnica s trojbokým granulovaným záveskom vyhotove- ná z pozláteného bronzu. Na veci nič nemení ak v celosti zachovaný kus i jeho fragment neležali v okolí hlavy ako regulárne nosené náušnice, ale boli priložené do druhotnej polohy.

Vzhladom na včasnohistorickú provenienciu nie je vhodné uvažovat’ o chronologickej citlivosti tangovaného korálika v 9. stor. Tento zástupca bol získaný zberom a pre esteticky pôsobivý vzhlad a výnimočnost' tvaru sa stal amuletom s rôznymi ochrannými schopnost̉ami. Presvedčenie o zníženej datovacej schopnosti celého náhrdelníka vyplynie z pestrej skladby korálikov piatich typov $\mathrm{v}$ siedmich farebných obmenách. Podla nich bol náhrdelník skladaný $\mathrm{v}$ miestnych pomeroch $\mathrm{z}$ dostupných exemplárov vyrobených $\mathrm{v}$ širšom časovom rozmedzí.

Zvyšné koráliky z analyzovaného náhrdelníka patria k zástupcom tradičných tvarov, štruktúry a farebnosti sklenej hmoty používaných počas celého vel'komoravského obdobia. Spomedzi nich je nápaditý sploštený gul'ovitý korálik z čierneho skla zdobený dvomi natavenými nitami lemujúcimi bodky zo žltého skla. Menšie súdkovité koráliky z priehladného skla sa vyskytli v dvoch kusoch, rovnako tak viacnásobne členené koráliky z modrého a žltého skla zložené $z$ dvoch segmentov. Náhrdelník doplńa sedem drobných kotúčových korálikov z tmavomodrého skla a 16 krúžkových korálikov zo zeleného a žltého skla.

Nesúrodá skladba korálikov je známa aj z hrobu 48 (tab. XX: 48: 1). Okrem kuželovitého korálika zo žltého skla sa v ňom našiel aj valcovitý korálik z tmavomodrého skla. Oba exempláre neležali v oblasti krčných stavcov, ale pri pravej strane hornej čeluste. Do tohto miesta sa mohol náhrdelník presunút počas dekompozície telesných zvyškov detského jedinca stredného veku. Iné predmety pohrebného inventára chýbajú. Vyšší sociálny status pochovaného by mohla $\mathrm{v}$ náznakoch pripomínat úzka pozdížna vrstva tmavosfarbenej zeminy s mikročasticami uhlíkov. Jej poloha vyvýšená nad dnom hrobu o $10 \mathrm{~cm}$ naznačuje, že môže íst’ o zvyšky doskového prekryvu.

Umiestnenie hrobu v okrajovej časti V. pohrebiskovej skupiny z východnej časti nekropoly mnoho neprezradí. Informatívnejšia je poloha hrobu 16 dopĺnajúceho líniovú zostavu hrobov 18 a 19 s hodnotnými striebornými a pozlátenými náušnicami veligradského typu.

\section{Súčasti odevu}

Štyri exempláre tejto kategórie pochádzajú zo štyroch hrobov (13, 17, 26 a 37; obr. 13: f). Podla toho táto kolekcia tvorí medzi hrobmi s pohrebným 
inventárom diel s hodnotou 10,5 \%. Medzi všetkými predmetmi materiálnej kultúry je podiel súčastí odevov $4 \%$ (obr. 5).

Do zúženej typologickej škály patrí kovový a sklený gombík s dvomi železnými prackami. Tie patria $\mathrm{k}$ súčastiam odevu slúžiacim ako jeho spínadlá. Ich nízka frekvencia vytvára rámcovú predstavu o jednoduchosti odevov nosených obyvatelmi vidieckeho prostredia.

\section{Typ 12 - Gombík so zvislo rebrovaným povrchom}

(obr. 6: 12)

Prvým špecifickým prvkom gombíka z hrobu 13 je mierne sploštený gulovitý tvar s priemerom $16 \mathrm{x}$ 12 mm (tab. VI: 13: 1), ktorý členia zvislé rebrá do ôsmich polí. Podla vrchlíka z hladkého plechu so závesným uškom pripojeného $\mathrm{k}$ hornému obvodu pláša bol gombík vytepaný z jedného kusa bronzového plechu. Jeho pozlátený plasticky členený povrch dotvára pôsobivý estetický dojem.

Počas druhotného porušenia hrobového interiéru bola zrejme pozmenená aj pôvodná poloha gombíka, ktorý sa tak ocitol napravo od predpokladanej lebky. Nedá sa preto stanovit', či gombík tvoril súčast’ odevu alebo bol iba priložený $\mathrm{k}$ pochovanému dietaatu podobne ako nôž špeciálneho využitia, keramická nádoba, vedro a príloha mäsitej potravy. Z ich skladby, doplnenej o nadpriemerné údaje hrobovej jamy sa dá odvodit’ vyššia pozícia tohto detského jedinca najmladšieho veku v miestnej komunite.

Ďalším špecifickým znakom analyzovaného predmetu je jeho výskyt na vidieckom pohrebisku, pretože ostatní zástupcovia predmetného typu sa prednostne sústred’ujú na lokalitách centrálneho významu a spájajú sa s jedincami s vyššou pozíciou vo vel'komoravskej societe. Zo Slovenska k nim patrí areál Devínskeho hradu s hrobom 191/86 s detským jedincom vyhíbeným na cintoríne $14 \mathrm{~m}$ južne od súvekej sakrálnej stavby (Plachá/Hlavicová/Keller 1990, 109, 110, tab. 37). Z územia Moravy sa k známej kolekcii pripájajú hroby 29, 69 a 274 z cintorína od 1. kostola v Břeclavi-Pohansku, v mikulčickej aglomerácii sa hroby zistili pri 2. a 6. kostole (Poulík 1957, 371; Profantová 2003, obr. 43: 76: 1, 2). K najvýznamnejším zástupcom patria hroby 50/50 a 51/50 zo Starého Města-Na valách (Hrubý 1955, 473, tab. 73: 22) a hroby 19/59, 173/59 a 209/59 z Uherského Hradišta-Sadov (Galuška 1996, 63, 100, obr. 60: 2-4). Dolné Věstonice a Nechvalín patria k pohrebiskám používaných mimo centier (Klanica 2006a, 78, 79).

Chronologická pozícia gombíkov so zvislo rebrovaným povrchom nie je opät chronologicky obmedzená iba na jeden kratší úsek. K najstarším exemplárom zo zlatého plechu vyskytujúcich sa už v staršom vel'komoravskom horizonte sa pripájajú neskoršie deriváty z bronzového plechu. Tie sa mohli používat' aj počas mladšieho horizontu (Galuška 1996, 100, 108; Pavlovičová 1996, 108). K nim patrí aj hrob 191/86, vyhíbený v areáli Devínskeho hradu (Samuel/Pomfyová 2015, 99). Podl’a kombinácie sprievodných nálezov mohol byt hrob 13 v Dolných Krškanoch vyhíbený už počas staršieho horizontu. Vzhl'adom na umiestnenie vo východnej časti nekropoly však reálnejšie vyznieva mladšia fáza pochovávania.

\section{Typ 13 - Sklený gombík}

(obr. 6: 13)

Nad pravým plecom detského jedinca stredného veku z hrobu 17 (tab. X: 17: 1) ležal gombík z bledozeleného skla so závesným uškom $z$ bronzového drôtu. Podla toho sa pripája $\mathrm{k}$ väčšine známych exemplárov s gulovitým i mierne splošteným tvarom s priemerom 11-13 mm. Dolnokrškanský exemplár sa od nich odlišuje nadmerne splošteným telom. Okrem vizuálneho vnemu to vystihujú aj rozmery $11 \times 7 \mathrm{~mm}$. Zmienená neobvyklost' musela vzniknút už pri výrobe chybnou manipuláciou, ked' sklená hmota v potrebnom rozsahu neobalila závesné uško, a tak sa jeho dížka voči $2-3 \mathrm{~mm}$ predížila na $6 \mathrm{~mm}$. Príbuznú podobu nadobudol aj gombík z ojedinelých hrobov na lokalite Nitra-Zobor-Šidloka-Vinohrady (Hanuliak 2001; 2004b, tab: LXXII: 4).

Zaznamenaná odlišnost' zrejme nemala vplyv na využitie gombíkov. Exemplár z ojedinelého hrobu sa našiel v lavej časti hrudníka, v analyzovanom hrobe zasa nad pravým plecom. Ak nebol gombík navlečený na nit prípadného náhrdelníka (porovnaj: Kraskovská 1965, 44; Marešová 1983, 41; Vendtová/Rejholec 1963, 243), mohol sa počas dekompozície pochovaného presunút $\mathrm{z}$ odevu do zaznamenanej druhotnej pozície. Oba prípady s detskými jedincami rozširujú množstvo zástupcov z danej skupiny na 56,5 \%. Zriedkavejšia je ich prítomnost' u nedospelých (21,7\%). Prekvapivo identická hodnota $(21,7 \%)$ sa vyskytla aj u dospelých. Pričom v hrobe 34 z Nitry-Lupky bol pochovaný dospelý muž stredného veku (Chropovský 1962, 186, tab. XI: 15).

Z kulminujúcej početnosti sklených gombíkov $\mathrm{v}$ detských hroboch a nedospelých možno vyčítat, že ich exempláre z 21 hrobov vyhĺbených na 17 nekropolách zo Slovenska naplńali svoje poslanie prednostne u príslušníkov z tejto skupiny. Bez ohladu na to, či išlo iba o funkčné spínadlá odevu, u ktorých mohla byt๋ v rôznom rozsahu rozšírená schopnost sociálnej indikácie prelínajúcej sa s napíňaním magickej ochrany dotyčného majitela (Galuška 2013, 182; Chorvátová 2009, 15; Klanica 1970, 421). Bez ohladu na väzbu takýchto predmetov $\mathrm{k}$ jedincom prevažujúceho veku zostáva stále nejasný ich pôvodný význam, ktorý sa pri štandardnej vel'kosti 
strácal na jednoduchom a farebne nenápadnom odeve obyvatelov dedinských sídlisk.

Sprievodné nálezové okolnosti poskytujú možnost' zaradit do staršieho vel'komoravského horizontu gombík predmetného typu nájdený v hrobe 10 z Bajča-Sociálneho domu, hrobe 20 z Michala nad Žitavou a hrobe 77 z Vel'kého Grobu (Hanuliak 2004b, tab. II: 7; LIII: 6; C: 6). Do povel'komoravského obdobia patrí hrob 123 z Čakajoviec, hrob 8 z Nitry-Horných Krškán (Hanuliak 2004b, tab. XIX: 4; LX: 8). Zvyšné hroby sú späté s mladším horizontom. K nim patrí aj hrob 11 z Bratislavy-Devína-Za kostolom, hrob 15 z Nitry-Lupky, hrob 1 z Nitry-Zobora-Šindolky-Vinohradov, hrob 75 z Pobedima-Na laze, hrob 2/49 zo Stupavy-Mástu, hrob 193 z Trnovca nad Váhom-Horného Jatova, hrob 6 z Tvrdošoviec-Kerektó (Hanuliak 2004b, tab. XIV: 4; LXIV: 19; LXX: 4; LXXII: 4; LXXV 3, 4; LXXIX: 5; LXXXIX: 20; XCIV: 22).

$\mathrm{Z}$ nedostatku sprievodných nálezov zostáva chronologické zaradenie pochovaného $\mathrm{z}$ dolnokrškanského hrobu 17 otvorené. Jedinú nepriamu indíciu poskytuje umiestnenie hrobu do vyššie spomenutej líniovej zostavy hrobov 16, 18 a 19 vyhíbených v II. pohrebiskovej skupine zo západnej časti nekropoly. V nich nájdené náušnice veligradského typu pripúštajú možnost' k zaradeniu pochovaných detských jedincov $\mathrm{k}$ lepšie situovaným príslušníkom miestnej komunity. Z nedostatku opôr je nelahké stanovit' $\mathrm{v}$ akom odstupe sa voči nim ocitol jedinec pochovaný iba so skleným gombíkom. Po zohl'adnení nadpriemerných rozmerov hrobovej jamy nepatril do skupiny s podpriemerným či priemerným postavením. Aj význam samotného gombíka ho s určitostou oddelí od zomrelých z plytkých hrobov bez pohrebného inventára.

\section{Typ 14 - Pracky}

(obr. 6: 14)

K spínadlám odevu z driekovej časti patriace pracky sa našli v hroboch 26 a 37. Z typologického hladiska má prvý koróziou poškodený reprezentant zriedkavejšie zastúpený polkruhový tvar zachovaný v zlomkoch. Cez jeho vnútorný úsek sa dal prevliect' kožený či textilný opasok široký $15 \mathrm{~mm}$.

Z druhého hrobu zasa pochádza pracka oválneho tvaru so zachovaným jazýčkom (tab. XVI: 37: 1). Cez jej vnútorný úsek sa mohol prevliekat’ opasok široký nanajvýš $11 \mathrm{~mm}$. Tento rozmer vcelku zodpovedá potrebám vlastníka pracky zastúpeného 6-7-ročným diet’atom. Poloha pracky v strede pása nevyvoláva pochybnosti o jej niekdajšom využití. V porovnaní s tým polkruhová pracka (tab. XII: 26: 1) z hrobu 26 zrejme skĺzla k l’avému kíbu stehennej kosti. Avšak takto naznačenú prítomnost’ závesného vrecka upevneného na predmetnom mieste nepotvrdili relevantné nálezy. Ak bola v hrobe skutočne pochovaná dospelá žena stredného veku, patrí k iným trom zriedkavým prípadom spájajúcim na Slovensku jedincov tohto pohlavia so železnými prackami.

Podla chýbajúcich príloh v hrobe 26 , keramickej nádoby priloženej do hrobu 37 (tab. XVI: 37: 2) a nízkych hodnôt metrických údajov nepatrili títo zomrelí k významnejším členom komunity. Tieto danosti rešpektuje odsunutie hrobov do okrajovej zóny V. a VII. pohrebiskovej skupiny z východnej časti nekropoly. Ich datovanie sa nedá spresnit', ked’že železné pracky nepatria sami o sebe k chronologicky citlivým predmetom.

\section{Predmety dennej potreby}

Zástupcovia tejto kategórie $\mathrm{v}$ počte $40 \mathrm{kusov}$ pochádzajú z 21 hrobov (obr. 9: a-f). Podla toho tvorí táto skupina medzi hrobmi s pohrebným inventárom diel s hodnotou 55,2 \%. Táto hodnota klesá na $40 \%$ medzi všetkými predmetmi materiálnej kultúry (obr. 5).

$\mathrm{V}$ rámci predmetnej kolekcie figurujú celé kusy a ich zlomky patriace k nožom, britvám, ociel'kam, úštepom, šidlám, praslenom, ktoré dopíňa ihelník s ihlou. Z predmetnej skladby vyplynie, že ide iba o osem tradičných zástupcov dennej potreby doplnených britvou patriacou k toaletným predmetom. Z neznámych príčin chýbajú kamenné brúsy, zástupcovia remeselníckych a polnohospodárskych nástrojov.

\section{Typ 15 - Nože}

(obr. 8: 15)

S celými exemplármi nožov a ich fragmentmi sa stretávame v 19 hroboch $(2,4,6-8,10,13-15,18$, 20, 27, 28, 43, 44, 49, 50, 52 a 53; obr. 9: a; tab. I: 2: 1; II: 4: 2; III: 6: 1; IV: 7: 3; 8: 3; VII: 13: 2; 14: 1, 2; IX: 15: 1; X: 18: 3; XI: 20:1; XIII: 27: 3; 28: 1; XVIII: 43: 1; XIX: 44: 1; XX: 49: 1; XXI: 50: 1; 52: 1). Podla toho reprezentujú tieto predmety $\mathrm{v}$ zostave pohrebného inventára najpočetnejšiu kolekciu nálezov s vyčísleným podielom $45,9 \%$. Skutočný počet celých zástupcov zvyšujú tri hroby so zlomkami nožov a hrob 14 (VII: 14: 1, 2), z ktorého pochádzajú dva celé exempláre z identickej vel'kostnej kategórie.

Prvotné členenie nožov podla tradične zohladňovaných údajov celkovej dížky iba potvrdilo dominantný výskyt zástupcov strednej vel'kostnej kategórie. K nej patria predmety s dížkou 103 mm až $140 \mathrm{~mm}$ doložené na pohrebisku v 70,7 \% prípadov. Skupinu krátkych nožov nedosahujúcich dĺžku $90 \mathrm{~mm}$ evidujeme v 17, $6 \%$ prípadov (tab. IV: 8: 3; XIII: 27: 3; XXI: 50: 1). K skupine dlhých nožov 


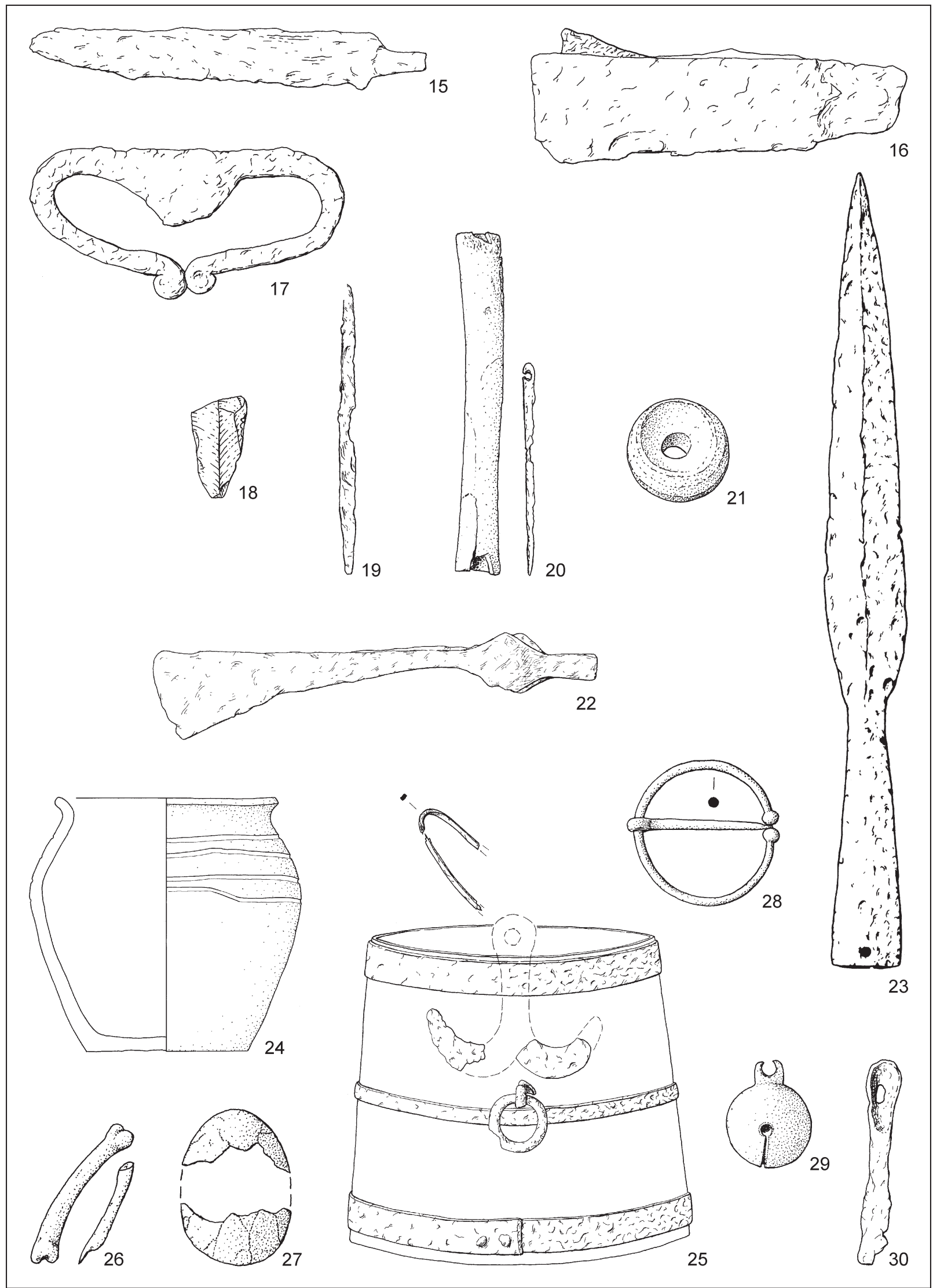

Obr. 8. Nitra-Dolné Krškany. Typologická skladba predmetov. 15-21 - predmety dennej potreby; 22, 23-zbrane; 24-30 predmety kultového charakteru. 
s podielom $11,7 \%$ a rozmermi nad $150 \mathrm{~mm}$ patria iba dva exempláre z hrobov 4 a 6 (tab. II: 4: 2; III: 6: 1). Druhý z nich sa do tejto kolekcie nezaradil na základe zväčšenej čepele, ale nadmerne predíženého tríňa.

Súčastou pracovného súboru s podielom $3,6 \%$ sú aj tri exempláre uložené do hrobov 4,10 a 53 (tab. I: 4: 3; V: 10: 1; XXI: 53:1) vo forme zlomkov čepelí. Ich obmedzené vypovedacie schopnosti rozširuje zástupca z hrobu 53. Tento zlomok pochádza z noža, ktorého čepel' ako jediná dosahuje šírku $20 \mathrm{~mm}$. Na lavej strane sa navyše nachádza $62 \mathrm{~mm}$ dlhý žliabok. Tento menej obvyklý prvok mal zvyšovat pružnost', súčasne i pevnost čepelí. Aj preto ho vo všeobecnosti nachádzame na dlhších nožoch so širšou čepelou zhotovovaných $\mathrm{k}$ náročnejšiemu využitiu ako výrazná väčšina nožov každodennej potreby (Čech/Kř́žek 1999, 134). Zmieňovaný zástupca patrí $\mathrm{k}$ takmer 80 \% iných prípadov, na ktorých bol žliabok umiestnený na lavej strane čepele (napr. Hanuliak 2004b, tab. XVII: 2; XXXV: 2; LIII: 5; LXXVIII: 4; LXXXV: 3; XCIV: 19; XCV: 2). Doklady o žliabku na pravej strane čepele sú napodiv zriedkavé (napr. Hanuliak 2004b, tab. V: 7; XLI: 1, 12).

K najčastejšie vyhodnocovaným zložkám nožov patrí takisto tvar nevyhnutný $\mathrm{k}$ ich typologickej klasifikácii. Vo vypracovanom prehlade sa vyníma obmedzená variačná škála, ktorú zásadným spôsobom ovplyvnila účelovosț využitia nožov. V prípade čepelí sa odlišnosti obmedzujú iba na líniu chrbta a koncovú čast’ s hrotom.

Z detailnejšieho rozboru vyplynula zvýšená prevaha nožov ( $52,6 \%$ prípadov) s rovným chrbtom a relatívne širšou čepelou zaoblenou $\mathrm{k}$ hrotu zo spodnej strany zhruba v rámci poslednej pätiny celkovej dížky (napr. hroby 4, 8, 14 a 20; tab. II: 4: 2; IV: 8: 3; VII: 14: 4; XI: 20: 1). V 31,6 \% prípadov majú zástupcovia zasa čepele so zmenšenou šírkou. Ostrie sa pritom dvíha k hrotu pozvolnejšie v rámci dlhšieho úseku (napr. hroby 2, 14, 27 a 28; tab. I: 2: 1; VII: 14: 5; XIII: 27: 3; 28: 1). Rozdielnost' oboch typov nie je v skutočnosti natolkko zásadná. Jej význam znižuje chýbajúce previazanie s pohlavím a vekom jedincov, s hodnotami pohrebného inventára. Zdá sa preto, že sledovaný prvok môže súvisiet’ s nevel'mi rozdielnou škálou výrobkov zhotovovaných rôznymi kováčmi.

Nože z poslednej skupiny sú zastúpené v 15,8 \% prípadov. V ich zostave figurujú exempláre so šikmo skosenou a prežliabnutou koncovou líniou chrbta napojenou na nižšie umiestnený hrot (hroby 6, 13 a 28; tab. III: 6: 1; VII: 13: 3; XI: 28: 1). Takýto prvok sa počas 9.-10. stor. objavuje na stredne dlhých a dlhých nožoch s kulminujúcim výskytom pri hodnote $10,8 \%$ a $19,5 \%$. To poukazuje na štandardnost' ich vyhotovovania ovplyvnenú konkrétnejšou formou využitia (Hanuliak 2004b, 124). V archeologických prameňoch však chýba zložka, ktorá by túto okolnost priblížila.

Na rozdiel od čepelí sú tŕne variabilnejšie sformované. Okrem rozdielnej dížky a šírky majú tieto časti hrotitý alebo pásikový tvar doplnený obojstranným zúžením i rozdielne odsadenými líniami. Z tvarovej rôznorodosti sprevádzanej odlišným napojením tŕňov na čepele plynie názor o zníženom význame týchto častí. Stabilita čepelí potrebná k zabezpečeniu stálej polohy reznej hrany sa musela docielit pomocou vsadenia koncovej časti čepele, nie iba hrotu, do rukoväte $\mathrm{z}$ organického materiálu.

$\mathrm{Z}$ nadmerne homogénnej skladby dolnokrškanských nožov sa odčleňujú iba dva exempláre. V prvom prípade je to nôž z hrobu 13 (tab. VII: 13: 2). Okrem preliačenej línie chrbta pri hrote púta pozornost nadmerne predĺžený hrotitý tŕñ. Identická podoba noža nájdeného $\mathrm{v}$ jednom hrobe z čakajovského pohrebiska a v Úlanoch nad Žitavou vylučuje, že by išlo o náhodný výtvor miestneho kováča. Reálnejšia je verzia o účelovo dotvorenej forme predurčenej k špecializovanej činnosti. $Z$ dnešného pohladu prichádza do úvahy i funkcia skalpela slúžiaceho na vytvorenie kratšej, no precízne umiestnenej reznej línie.

Nôž opísaného typu bol do hrobu 13 zo spracúvanej nekropoly uložený k nanajvýš 3-5-mesačnému dietatu, ktoré ho sotva využívalo na uvedený účel. Pravdepodobnejšie vyznieva alternatíva, podla ktorej mohol byt’ nôž využitý k liečitel'skému účelu. Po neúspešnom zákroku musel byṫ, podla zásad kontaktnej mágie, ponechaný $\mathrm{v}$ hrobe pretože prišiel do styku s nečistým jedincom (Bednárik 1939, 61; Jágerová 2001, 16; Krumphanzlová 1972, 200). Sociálny status tohto dietata najmladšieho veku výrazne navyšuje gombík so zvislo rebrovaným povrchom z pozláteného bronzového plechu doplnený prílohou mäsitej potravy a d’alšími potravinovými článkami uloženými v keramickej nádobe i vo vedre.

Identický typ noža pochádza takisto z čakajovského hrobu 230 (Rejholcová 1995b, 26; tab. XLI: 4-10). Inventár zložený z krúžkových náušníc, korálikov, praslenu a brúsu má síce nižšiu hodnotu. Napriek tomu reálnejšie vyznieva možnost' využitia predmetného noža k zamýšlanej činnosti, kedže bola $\mathrm{v}$ tomto hrobe pochovaná dospelá žena. V hrobe 3 z Úlan nad Žitavou bola takisto pochovaná dospelá žena s krúžkovými náušnicami, korálikmi, no potravinové články sa obmedzili iba na mäsitú prílohu (Liptáková 1963, 224, obr. 3: 8-11). Tak v čakajovskom prípade, ako aj v tomto hrobe dosahujú zložky pohrebného rítu nadpriemerné parametre.

Druhý neobvyklý variant noža z dolnokrškanskej kolekcie pochádza z hrobu 6 (tab. III: 6: 1). Pozornost’ nevzbudzuje čepel' s mierne prežliabnutým koncovým úsekom chrbta. Podla rozmerov patrí 


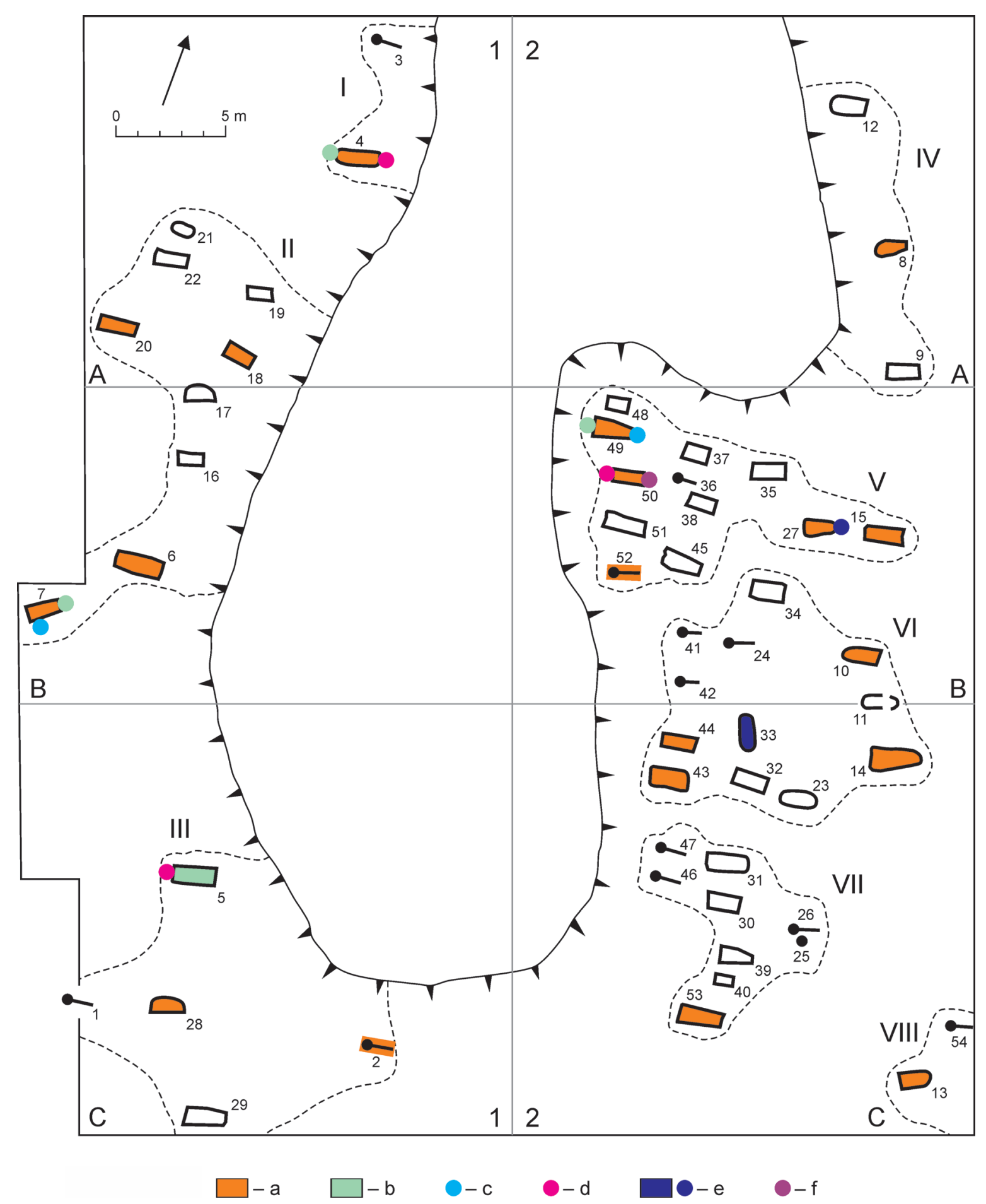

Obr. 9. Nitra-Dolné Krškany. Rozmiestnenie hrobov s predmetmi dennej potreby. Legenda: a - nôž (typ 15); b - úštep (typ 18); c - ociel'ka (typ 17); d - šidlo (typ 19); e - praslen (typ 21); f - ihelník, ihla.

táto čast' k nožom zo strednej vel'kostnej kategórie. Výnimočný je svojimi rozmermi pásikový tŕn široký $13 \mathrm{~mm}$ a dlhý $117 \mathrm{~mm}$. Jeho obe strany pokrývajú platničky vyrobené z parohoviny. Ich oblúkovito vyklenutý dôkladne vyhladený povrch zdobí šest' dvojíc sústredných kružníc.
Podl'a predíženej rukoväte mohol byt’ opísaný nôž vhodný aj na bojové účely. Vyššia estetická hodnota zdobenej rukoväte zhotovená náročnejšími remeselnými postupmi poskytuje príležitost’ k označeniu noža za atribút vyššieho sociálneho statusu tohto muža. S takýmto poslaním môže súvi- 
siet’ umiestnenie noža do neprehliadnutelnej pozície zo strednej časti hrudníka, mimo obvyklých polôh každodenne využívaných nožov. Okrem vedra presviedčajú o vyššom sociálnom statuse jedinca takisto nadpriemerné metrické údaje hrobovej jamy (híbka $200 \mathrm{~cm}$, objem 3,5 m³).

Vzhlad drevených rukovätí nožov nepoznáme. Aj preto si našu pozornost' zasluhujú reprezentanti vyhotovení zo zvieracích kostí a parohoviny. K sporadickým prípadom tejto kategórie, so signalizovanými prejavmi prestížnejšieho postavenia jedincov v komunite, patrí nôž z hrobu 4/65 z Tvrdošoviec-Kökép, z hrobu 36 z Úlan nad Žitavou a z hrobu 78 z Vel'kého Grobu (Hanuliak 2004b, tab. XCVI: 10; XCVIII: 3; C: 10). Obloženie rukoväte noža z Michala nad Žitavou výnimočne nahradil ihelník zdobený rytým dekórom vysústružený z parohoviny (Hanuliak 2004b, tab. LII: 1).

$\mathrm{Z}$ analýzy príslušných zložiek pohrebného rítu vyplynie popri inom i priama väzba nožov $\mathrm{k}$ dospelým mužom kulminujúca pri hodnote $47,4 \%$. Napohlad znížený kontakt dospelých žien s každodenne využívanými nožmi by mala demonštrovat hodnota $26,3 \%$. Tento údaj nie je akiste rovnako reálny ako identická frekvencia zaznamenaná $\mathrm{v}$ detských hroboch. Najmä u jedincov z najmladšej a strednej vekovej skupiny sa vynárajú pochybnosti o obvyklom využívaní nožov.

U dospelých žien sa pochybnosti tohto druhu vytrácajú aj preto, lebo sa známi zástupcovia nachádzali v tradičných miestach. K nim patrí lavá, výnimočne aj pravá čast’ panvy, vnútorná strana lavého lakta a predlaktia. U dospelých mužov nie je núdza aj o menej obvyklé miesta vrátane priečnej polohy cez lavé predkolenie a stred hrudníka.

$\mathrm{K}$ dodatočne priloženým patria takisto nože nájdené s inými predmetmi dennej potreby $\mathrm{v}$ rámci zhluku pri lavom alebo pravom kolene dospelých mužov. V takýchto prípadoch sa pripúšta existencia závesných vreciek. Ani uvedený moment však nepribližuje dôvod, pre ktorý vrecká neležali v širšom okolí panvy a stehenných kostí. Zohladňovanie polôh nadobúda dôležitost' $\mathrm{v}$ prípade čepelí uložených do hrobov v podobe zlomkov. A to najmä preto, že ide o miesta signifikantné pre celé nože. Podl'a tohto mohli byt' fragmenty kladené do hrobu preto, aby nahrádzali rovnocenné kusy celých a reálne využitel'ných predmetov.

Spracúvané predmety nie sú vo všeobecnosti vhodné $\mathrm{k}$ špecifikácii postavenia jedincov $\mathrm{v}$ danej komunite. V príslušných hroboch vystupujú ako osamotené exempláre alebo sprievodné doplnky iných príloh rozdielnej hodnoty. Z rovnakých príčin, ako aj pre ustálený tvar, nie sú sami o sebe vhodné $\mathrm{k}$ chronologickej špecifikácii príslušných hrobov. Zaujímavý poznatok vyplynul z priestoro- vej pozície hrobov s nožmi v pohrebiskovom areáli (obr. 9: a). Po zohladnení celkového počtu hrobov možno v náznakoch postrehnút pokles ukladania nožov do hrobov počas vývojovej línie pochovávania. Zatial' čo v západnej časti predstavuje ich podiel $43,8 \%$, vo východnej už iba $31,5 \%$.

V skupine hrobov s nožmi patrí zvýšená pozornost’ dvojici nožov nájdených $\mathrm{v}$ l’avej časti panvy dospelej ženy stredného veku z hrobu 14 . Vdaka nim sa indikatívne dopĺñajú známe nálezové okolnosti zložené zo strieborných náušníc špecifického typu, vedra, mäsitej prílohy a $\mathrm{z}$ hrobovej jamy s najväčšími metrickými údajmi na pohrebisku. Ich kombinácia je postačujúca k preukázaniu úrovne sociálnej pozície pochovanej. Na Slovensku sa identické prípady zaznamenali $\mathrm{v}$ deviatich hroboch. Na ilustráciu možno uviest’ hrob 14 z Bíne-Hospodárskeho dvora fary (Holčík 1991, 97, obr. 6), hroby 163 a 226 z Čakajoviec (Rejholcová 1995b, 18, 25, tab. XXXIII: 8, 9; XLII: 5, 6), hrob 20 z Michala nad Žitavou (Točík 1971, 195, tab. LIII: 1, 32), hroby 2, 7, 22, 27, 46 a 77 z Nitry-Lupky (Chropovský 1962, 202, 203). K reprezentantom z územia Moravy (napr. Hochmanová-Vávrová 1962, 233; Marešová 1983, 81) sa dajú pripojił štyri hroby z Lumbeho zahrady Pražského hradu (Frolík 2014, 65). V pertraktovaných prípadoch boli nože zasunuté pôvodne $\mathrm{v}$ drevených pošvách. Nachádzali sa $\mathrm{v}$ panve a $\mathrm{v}$ jej najbližšom okolí, medzi pochovanými sú v prevahe zastúpené dospelé ženy s bohatým pohrebným inventárom. V Nitre-Lupke ide, naopak, o dospelých mužov.

\section{Typ 16 - Britoy}

(obr. 8: 16)

Toaletné predmety sú na nekropole zredukované na britvy uložené do dvoch hrobov (4 a 5; obr. 13: d; tab. II: 4: 5; 5: 4) umiestnených v II. a III. pohrebiskovej skupine. Údaj s hodnotou 3,7 \% nevystihuje ich skutočný výskyt, pretože pochádzajú iba z hrobov dospelých mužov. Jedinci z tejto kategórie netvoria medzi pochovanými ani tretinový diel.

Základné časti železných britiev, zložených z noža a ochranného puzdra, lemujú subtílne línie. Väčšinu z nich, vrátane otočného čapu a ostria, znehodnotili účinky korózie. Na nájdených exemplároch sa zachovala jeho zhrubnutá línia smerujúca $\mathrm{k}$ hrotu zo spodnej strany. Na britve z hrobu 4 (tab II: 4: 5) vysúvanie noža z puzdra ulahčovala trojuholníkovito rozšírená línia chrbta. U zástupcu z hrobu 5 (tab. II: 5: 4) túto úlohu prevzal hrotitý výčnelok z koncovej strany noža.

Pri hodnotení týchto toaletných predmetov sa pozornost' zvyčajne venuje kvalitnejšie zachovaným puzdrám zhotoveným $\mathrm{z}$ prehnutého železného plechu. Podla nich patria nálezy z Dolných Krškán 
k najčastejším zástupcom s lichobežníkovitým tvarom postranníc strednej vel'kostnej kategórie dlhých $92 \mathrm{~mm}$ a $94 \mathrm{~mm}$. Šírkové parametre zachytáva rozmedzie 15-18 x 22-25 mm (Dostál 1966, 87; Měřínský 1985, 48; Szőke 1992, 106).

$\mathrm{V}$ súlade $\mathrm{s}$ väčšinovým štandardom sa britvy vyskytli pri dospelých mužoch strednej vekovej kategórie (Hanuliak 2004b, 134, obr. 145). Na rozdiel od nožov vystihuje primerane nadsadenú hodnotu britiev takisto ich trvalejšie nosenie $\mathrm{v}$ závesných vreckách z organických materiálov. Tie boli na lokalite s d’alšími drobnými predmetmi umiestnené k l’avému kolenu alebo konča chodidiel. Tieto miesta patria k spodným úsekom dolných končatín, v ktorých prenosné mobiliáre nemohli byt๋ trvalejšie nosené.

Okrem nadpriemerných híbkových a objemových mier preukazuje vyšší sociálny status pochovaného z hrobu 4 aj kopija s doskovou podložkou umiestnenou pod telom. Podla nich sa tento zomrelý pripája k najvýznamnejším príslušníkom miestnej komunity. Súčasne sa tým podporuje starší názor o úzkom prepojení popredných členov vel'komoravskej society s upraveným zovňajškom a oholenou tvárou (Kouřil 2014, 70; Marešová 1983, 82; Szőke 1992, 108). Do tejto skupiny patril podla identických sprievodných zložiek napríklad aj jedinec z hrobu 36a/89 v Mužle-Čenkove-Orechovom sade, hrobu 587 z Čakajoviec, hrobu 2/60 z Ladíc (Hanuliak/Kuzma 2015, 277, 278, tab. XC; XCI; Rejholcová 1995b, 64, 65, tab. XCVI; Vendtová 1962, 398, obr. 138: 5-15).

Pre chýbajúcu zbraň a úpravu hrobovej jamy drevom nie je pozícia dospelého muža z hrobu 5 v Nitre-Dolných Krškanoch v sledovanom vztahu natol'ko presvedčivá. Metrické údaje hrobovej jamy si napriek tomu udržali nadpriemerné parametre. Kombinácia nálezov i ostatných sprievodných ukazovatelov spájajú hrob 4 so starším horizontom. Takáto špecifikácia nie je natol'ko presvedčivá pri hrobe 5, čo však nevylučuje identické chronologické zaradenie.

\section{Typ 17 - Ociel'ky}

(obr. 8: 17)

Železné predmety slúžiace na zakladanie ohňa pochádzajú z dvoch hrobov (7 a 49; obr. 9: c; tab. IV: 7: 1/1, 1/2; XIX: 49: 2) vyhíbených v II. a V. pohrebiskovej skupine. Patria k najčastejšie zhotovovaným oválnym formám s trojuholníkovitým lalokom na vnútornom obvode a koncami zvinutými do očiek. Ich dížky neprevyšujú $85 \mathrm{~mm}$. Platí to nielen pre exemplár z hrobu 49 zachovaný v celosti, ale aj pre dvoch zlomkovitých zástupcov rôznej vel'kosti z hrobu 7 .

Koróziou poškodené exempláre bývajú v hroboch pomerne časté. Za nezvyčajné však treba označit uloženie dvoch znefunkčnených častí do jediného hrobu. Podnet stojaci za výsledným aktom zostáva neznámy. S vel'kou pravdepodobnostou sa $\mathrm{v}$ danom prípade pozostalí rozhodli plnohodnotnú, v pozemskom svete využitel'nú ociel'ku, nahradit dvomi vyradenými zlomkami. Plnohodnotné poslanie ocielok z evidovaných hrobov napohlad zreálňujú priložené úštepy. Tieto kamienky boli uložené do lavej časti hrudníka a k vnútornej strane pravého kolena dospelých mužov stredného veku.

Typ 18 - Úštepy

(obr. 8: 18)

Nálezy tejto kategórie, predurčené na vykresávanie iskier, sa našli v štyroch hroboch $(4,5,7$ a 49; obr. 9: b; tab. II: 6/1, 6/2; 5: 3/1, 3/2; IV: 7: 2; XX: 49: 3) z I.-III. a V. skupiny. Iba v hrobe 7 a 49 ich sprevádzali ociel'ky. V hroboch 4 a 5 sa úštepy vyskytli, no ociel'ky chýbajú. Podla V. Budinského-Kričku (1959, 25), V. Hrubého $(1955,117)$ a B. M. Szókeho $(1992 b$, 104) mohli ociel'ky rovnako úspešne nahrádzat' iné železné predmety zastúpené napríklad zlomkom noža, britvou alebo šidlom. Takáto možnost’ však musela byt๋ zreálnená zvýšeným obsah uhlíka v exponovaných častiach predmetov, aby sa zabezpečila dostatočne zvýšená energia vykresaných iskier (Pleiner 1962, 163).

Odborné analýzy M. Chebena z Archeologického ústavu $\mathrm{SAV}$, zamerané na sledovanie pracovných stôp, nepotvrdili očakávané využitie predmetných úštepov. Podla nich nájdené exempláre pozdížneho i trojuholníkovitého tvaru z rádiolaritu, limnokvarcitu a silicitu s obmedzenými rozmermi na 11-30 x 10-15 mm predstavovali symbolickú náhradu skutočných kresacích kamienkov uložených na nekropole $\mathrm{k}$ dospelým mužom strednej vekovej skupiny. Okrem zomrelého z hrobu 45, azda z hrobu 5, s významnejším postavením v komunite, sa jedincom z hrobov 7 a 49 dá pripísat nanajvýš priemerná spoločenská pozícia.

Niekdajšie praktické využitie artefaktov zjavne spochybňuje ich obmedzená vel'kost'. Reálnejšie preto vyznieva ich spojenie s pravekými lokalitami, z ktorých boli takého exempláre zámerne získavané, pretože im mohli byṫ pripisované magické schopnosti s ochrannými účinkami (Přichystalová 2014, 251).

\section{Typ 19 - Šidlá}

(obr. 8: 19)

K dvom predchádzajúcim typom drobných predmetov každodenného využitia treba pripojit šidlá s dížkou 55-91 mm. Vyhotovené sú zo železnej tyčinky štvorhranného prierezu s priemerom $2,5-3 \times 2,5-3 \mathrm{~mm}$. Táto čast’ bola vsadená do dre- 
venej rukoväte. Zahrotená pracovná čast’ má zasa kruhový prierez s priemerom $2-5 \mathrm{~mm}$.

Opísané nástroje pochádzajú z troch hrobov $(4,5$ a 50; obr. 9: d; tab. I: 4: 4; II: 5: 2; XXI: 50: 3) vyhĺbených v I., III. a V. pohrebiskovej skupine. V týchto prípadoch sprevádzajú predmetné šidlá úštepy, nože a britvy, výnimočne aj ihla s ihelníkom a kruhová spona. V iných zostavách sa $\mathrm{k}$ nim pripájajú ociel'ky. Zhluková poloha prezrádza, že kolekcie tohto zloženia mohli byt trvalejšie nosené $\mathrm{v}$ závesných vreckách z textilných materiálov alebo kože. Ide $\mathrm{v}$ podstate o mobilnú zostavu dôležitých všestranne využitelných predmetov dennej potreby, rôznych cenností a amuletov príznačnú vo vel'komoravskom období pre dospelých mužov s vyššou spoločenskou pozíciou (Kraskovská/Paulík 1978, 109; Hochmanová-Vávrová 1962, 234; Profantová 2015, 76). V súlade $\mathrm{s}$ vtedajšími zásadami boli pertraktované vrecká so šidlami priložené pozostalými členmi rodinného zväzku $\mathrm{k}$ lavému kolenu, $\mathrm{k}$ pravému chodidlu, alebo konča chodidiel. V hrobe 7 a 49 túto škálu dopíňa poloha zo strednej časti hrudníka a vnútornej strany pravého kolena. V sumáre ide o miesta, $\mathrm{v}$ ktorých sa predmetné mobiliáre nemohli v každodennom živote trvalejšie nosit'.

V prípade hrobov 4 a 5 zostáva nad’alej v platnosti vyššie preukázaná väzba drobných predmetov so spoločenskou pozíciou dospelých mužov. Sprievodným ukazovatelom z hrobu 50 chýba patričná presvedčivost'.

Typ 20 - Ihla a ihelník

(obr. 8: 20/1, 20/2)

V nasledujúcej časti zhodnocované dva napohlad rozdielne typy predmetov spája nielen ich ojedinelý výskyt na nekropole, ale aj bezprostredná funkčná väzba. Ihelník zhotovený z dutej kosti chránil pred stratou a poškodením vzácnu ihlu, ktorá bola v takomto prenosnom puzdre uschovaná a pri pohrebe uložená do hrobu 50 (obr. 9: f; tab. XXI: 50: 2/1, 2/2) umiestneného v V. pohrebiskovej skupine.

Podla posudku C. Ambrosa z Archeologického ústavu SAV zhotovili ihelník z kosti husi domácej (Anser anser dom.). Ako väčšina známych výrobkov danej proveniencie má aj tento predmet nezdobený povrch. Oválny prierez s priemerom $12 \times 8 \mathrm{~mm}$ dopíňa dížka $87 \mathrm{~mm}$. Ihla je zasa zhotovená zo železnej tyčinky s kruhovým prierezom. Jej $55 \mathrm{~mm}$ dlhé telo sa od zhrubnutej časti s prerazeným otvorom postupne zužuje.

Menej obvyklý je, naopak, výskyt ihly, slúžiacej na zošívanie textilných materiálov, $\mathrm{v}$ hrobe dospelého muža stareckého veku. Takmer absolútna prevaha ihiel z územia Slovenska sa totiž spája s hrobmi dospelých žien (Hanuliak 2004b, 132). K výnimočným prípadom uloženej ihly alebo ihelníka k dospelému mužovi patrí hrob 52 z Pobedima-Na laze (Vendtová 1969, 185), hrob 7 z Bajča-Medzi kanálmi (Ruttkay, M. 2002, 291, obr. 42; 43: 19) a hrob 573 z Čakajoviec (Rejholcová 1995b, 62, tab. LXXXIX: 14). K. Marešová $(1983,86)$ uvádza tri podobné prípady dospelých mužov z Uherského Hradišta-Horných Kotvic pochovaných s ihlami v ihelníkoch i samostatnými ihlami.

Pochybnosti o plnohodnotnom využívaní ihly mužským jedincom $\mathrm{z}$ dolnokrškanského hrobu sčasti oslabuje jej spoločný výskyt s dalšími predmetmi dennej potreby uloženými pri pravom chodidle pochovaného. V hroboch dospelých žien tejto komunity sa zhluková pozícia predmetov z tejto skupiny nevyskytla. K spresneniu spoločenskej pozície dotyčného muža chýbajú adekvátne opory.

\section{Typ 21 - Prasleny}

(obr. 8: 21)

Medzi predmetmi dennej potreby predstavujú keramické prasleny jediných zástupcov doložených výlučne $\mathrm{v}$ hroboch dospelých žien. V sumáre ide o dva hroby (27 a 33; obr. 9: e; tab. XIII: 27: 4; XV: 33: 4) vyhíbené v V. a VI. pohrebiskovej skupine.

Získané exempláre sú zhotovené z jemnej hliny, s povrchom vypáleným do svetlohnedej a hnedej farby. Prvý z nich má asymetrický dvojkónický tvar s preliačenou hornou plochou, druhý má pravidelnú dvojkónickú formu. Podla priemeru 20-24 mm a výšky $21 \mathrm{~mm}$, resp. priemeru 25-34 mm a výšky $16 \mathrm{~mm}$ patria títo zástupcovia $\mathrm{k}$ najčastejšie nachádzaným reprezentantom strednej kategórie (Hanuliak 2004b, 136; Marek/Kostelníková 1998, 194, 195, obr. 10; 11).

Počas zvažovania okolností ich umiestňovania do hrobov sa sporné momenty nevyskytli, hoci nejde o solitérne kusy, ale o zotrvačníkové časti vretien slúžiacich k navíjaniu súkaných nití (Vignatiová 1992, 57). Podla tohto prasleny súvisia so sezónne vykonávanými aktivitami, nie s každodennými podomáckymi prácami. Akiste aj preto sa s nimi nestretávame na každom pohrebisku. Aj počet evidovaných hrobov s takouto prílohou nebýva vysoký. Ani ich poloha v hrobovej jame nie je ustálená pre mnohorakosṫ známych variantov. Potvrdzujú to aj dva prípady z dolnokrškanských hrobov zastúpené polohou pri pravom kolene a v pravej časti panvy.

Podla predchádzajúcich okolností sa nepripúšta trvalejšie nosenie vretien s praslenmi počas iných každodenných aktivít. Preukazovanie ich vztahu k zomrelým zostalo v kompetencii pozostalých, ktorí sa riadili bližšie neznámymi okolnostami. Zrejme aj preto takéto predmety nachádzame pri zomrelých s rozdielnym sociálnym statusom bez náznakovej väzby k istému chronologickému obdobiu. 


\section{Zbrane}

Dvaja zástupcovia tejto kategórie pochádzajú $z$ dvoch hrobov (4, 8; obr. 13: e). Podla toho tvorí táto skupina medzi hrobmi s pohrebným inventárom diel s hodnotou $5,3 \%$. Zbrane tvoria $2 \%$ nálezov z pohrebiska (obr. 5). Z evidovanej skladby vyplynie, že ide o dvoch tradičných zástupcov zbraní. Z neznámych príčin chýba v zostave pestrejšia skladba príslušných druhov z oboch kategórií. Okrem sečných zbraní zjavne absentujú hroty šípov a súčasti bojovníckeho výstroja zastúpeného vo zvýšenej miere ostrohami.

\section{Typ 22 - Kopija}

(obr. 8: 22)

Jediný exemplár patriaci k žrdovo-bodným zbraniam sa spája s dospelým mužom z hrobu 4 (tab. II: 4: 1) vyhíbenom v I. pohrebiskovej skupine.

Hrot s celkovou dížkou $347 \mathrm{~mm}$ pozostáva z pravidelne vyklenutého listu (dí. 233, š. $35 \mathrm{~mm}$ ) napojeného na stredne dlhú kuželovitú tulajku (dí. $114 \mathrm{~mm}$, pr. $16-30 \mathrm{~mm}$ ) s dierkou pre upevňovací klinec drevenej násady. Uvedené znaky sa stotožňujú s parametrami, ktoré A. Ruttkay $(1976,300)$ označil za určujúce pre reprezentantov druhého variantu II. skupiny kopijí (Ruttkay, A. 2002, obr. 4). Frekvencia výskytu danej formy v pracovnom súbore prevyšuje početnost prvého variantu so širším listom o $22 \%$.

Kosoštvorcový prierez listu s mierne zvýrazneným stredovým rebrom patrí k menej obvyklým detailom. Z analýzy 11 hrotov kopijí z 10 lokalít vyplynula okrem iného i rozdielnost' $\mathrm{v}$ dížkach listov voči tulajkám. Príkladom je list $\mathrm{z}$ hrobu 6 v Lužiankach (Rajnič 1941) a z hrobu 58/61 v Kopčanoch-Hrúdoch I (Kraskovská 1965, 33, obr. 12: 7), ktoré zaberajú z celkovej dížky hrotu zhruba $64 \%$. V prípade zberového nálezu z Bojničiek (Bialeková 1993, 241, obr. 14) ide o $71 \%$.

Exemplár z Dolných Krškán sa hodnotou 66 \% iba nevelmi líši od údajov vyčíslených u zástupcu z hrobu 1/49 zo Stupavy-Mástu (Kraskovská 1954, 146, 147, tab. II: 5), hrobu 587 z Čakajoviec (Rejholcová 1995b, 64, tab. XCIV: 2), exemplára z hrobu 43 zo Svätého Petra (Béreš 1995, 119, obr. 23: 9) a hrobov 37 a 86 z Vel'kého Grobu (Chropovský 1957, 178, 183, tab. VI: 18; XI: 1).

Naopak, z kolekcie sa vymyká hrot kopije z hrobu 39 z Michala nad Žitavou (Točík 1971, 197, 198, tab. LIV: 11). Jeho list zaberá z celkovej dížky iba $51 \%$ i preto pri zbežnom pohlade dominuje u kopije predĺžená tulajka so zväčšeným priemerom. Takýto tvar býva hojnejší na pohrebiskách z avarského kaganátu, ku ktorým patria takisto Košice-Šebastovce (Budinský-Krička/Točík 1991, tab. VI: 67: 21; XI: 86: 48; XVIII: 131: 28).
K precíznejšiemu typologického triedeniu pertraktovanej kolekcie hrotov sa dopracoval M. Husár. Podla jeho kritérií patria evidovaní zástupcovia $\mathrm{k}$ variantu $\mathrm{BCa}$ i $\mathrm{BDa}$. $\mathrm{V}$ prvom prípade je tangovaný tvar bližší $\mathrm{k}$ vŕbovému, $\mathrm{v}$ druhom prípade $\mathrm{k}$ topolovému listu (Husár 2014, 40, 52, 53).

K významnejším poznatkom patrí preukázanie výskytu analyzovaného typu kopijí v európskom prostredí už pred vznikom avarského kaganátu, postupného úbytku predmetných zástupcov počas 7.-8. stor., vrcholiaceho na prelome 8. a 9. stor. Z nášho pohl'adu je významnejšie kontinuálne prepojenie výskytu s následnou etapou od 9. stor., počas ktorej dochádza k narastaniu ich obluby (Husár 2014, 45, 90; Kovács 1982, 255, Ruttkay, A. 1976, 300). Aj vd’aka tomu sa potvrdzuje predpoklad o dlhodobom autochtónnom vývoji danej formy (Tomka 2000, 194-196).

Menej čitatel'né výsledky poskytuje zhodnocovanie východiskových zložiek využívaných tradične k špecifikácii sociálnej pozície pochovaných (Kouřil 2005a, 86-90). Ich úzky vzt’ah ku kopijám je zrejmý, kedže sa hroty ocitajú vo výraznej prevahe na pravej strane od pravého pleca po hlavu. Nesporný je takisto reálny i symbolizujúci význam kopijí v hroboch, ktoré po dvojostrých mečoch predstavujú druhú najúčinnejšiu zbraň (Měřínský 1985, 63).

Napriek tomu s výnimkou hrobu 85 z Cífera-Pácu (Fusek 2006, 32, obr. 8, tab. III) a hrobu 587 z Čakajoviec (Rejholcová 1995b, 64) nenapíňajú ostatné predmety pohrebného inventára očakávanú nadpriemernost' pripisovanú peším bojovníkom (Csiky 2011-2012, 91).

Táto skutočnosṫ sa prejavuje $\mathrm{v}$ absencii iných druhov militárií. Britvy a vedierka sú doložené iba $\mathrm{v}$ dvoch hroboch, prílohy mäsitej potravy v iných dvoch hroboch. Naproti tomu keramické nádoby a nože poznáme zo šiestich hrobov. K takejto skupine sa pripája aj hrob 4 z Dolných Krškán s priloženým celým nožom a iným zlomkom, šidlom a britvou. Chýbajúci nadpriemerný objem hrobovej jamy symbolicky zrejme nahrádza dosková podložka, na ktorú bol jedinec uložený. Úpravy hrobovej jamy drevenou konštrukciou rôzneho typu sa zistili ešte v hrobe 39 z Michala nad Žitavou, v hroboch 37 a 86 z Vel'kého Grobu, ktorých jamy nadobudli nadpriemerný objem $\mathrm{v}$ rozsahu od $3,6 \mathrm{~m}^{3}$ po $10 \mathrm{~m}^{3}$. $\mathrm{Na}$ základe zistených skutočností patria tieto hroby, ako aj dolnokrškanský hrob 4 a azda aj hrob 58/61 z Kopčian-Hrúdov I, hrob 39 z Michala nad Žitavou so spomenutými reprezentantmi z Cífera-Pácu a Čakajoviec, do staršieho vel'komoravského horizontu. S mladším horizontom sa zrejme spája hrob 6 z Lužianok a hrob 1/49 zo Stupavy-Mástu. $\mathrm{Z}$ nedostatku potrebných opôr sa zvyšné prípady, vrátane hrobu 43 zo Svätého Petra nedajú výstižnejšie chronologicky špecifikovat'. 
Typ 23 - Sekera

(obr. 8: 23)

Odlišným typom zbrane je sekera v hrobe 8 (tab. IV: 8: 1) vyhíbenom v IV. pohrebiskovej skupine. Tento zástupca úderových militárií ležal na mieste, ktoré pôvodne priliehalo $\mathrm{k}$ pravému chodidlu detského jedinca stredného veku.

Z typologického hladiska sa exemplár svojimi znakmi blíži k parametrom vyčlenených $A$. Ruttkayom $(1976,306)$ pre tzv. úzke sekery typu II Aa. $Z$ nich treba uviest' mierne vejárovite rozšírené telo, sčasti nadol vzad sklonené ostrie, zvislo nasadený otvor pre porisko s nízkymi postrannými lalokmi a krátkym tylom kvadratického prierezu. Z rozmerov možno zasa vybrat' celkovú dížku 138 mm, ktorá sa ideálne začleňuje medzi dva okrajové údaje s hodnotou $117 \mathrm{~mm}$ a $186 \mathrm{~mm}$.

Z porovnávania d’alších údajov sekery so štandardnými charakteristikami sa postupne dotvorí presvedčenie o subtílnosti predmetnej formy. Pod uvádzaným limitom sa napríklad ocitá dĺžka ostria (30 mm), obojstranná výška trojuholníkovitých lalokov $(20 \mathrm{~mm})$, kvadratický prierez obucha $(8 \times 9 \mathrm{~mm})$ i priemer oválneho poriskového otvoru $(19 \times 16 \mathrm{~mm})$.

Podla A. Bartoškovej (1986, 79, 80, 111), odvolávajúcej sa na $M$. Ch. Aleškovského (1960, 71-75) sa naposledy uvedenou hodnotou skôr spochybňuje zhotovenie sekery na pracovné účely. Zvyšujú sa, naopak, dôvody $\mathrm{k}$ jej zaradeniu medzi úderové zbrane. Využitie sekery v reálnom boji napriek tomu oslabuje údaj s vel'kostou poriskového otvoru, so zmenšenou hrúbkou exponovanej časti tela i s celkovou hmotnostou obmedzenou na 198 gramov.

K reálnejšiemu vystihnutiu predmetných parametrov možno pre porovnanie uviest' ilustračné príklady sekier identického typu z hrobu $103 \mathrm{~A}$ v Bratislave-Devíne-Za kostolom, hrobu 151 v Čakajovciach, hrobu 12 v Kopčanoch-Hrúdoch I, hrobu 1/46 v Leviciach, hrobov 4 a 11 v Trenčíne-Biskupiciach a hrobu $9 \mathrm{v}$ Žabokrekoch (Hanuliak 2004b, tab. XIV: 1; XIX: 13; XLVIII: 7; LXXXVI: 10, 11; CVIII: 10). Zo sekier tohto typu získaných v Uherskom Hradišti-Horných Kotviciach je dolnokrškanskej sekere najviac blízky exemplár z hrobu 73 s nadpriemerným objemom priložený k "chlapcovi“ (Marešová 1983, 35, tab. 13: 1).

Je vcelku pravdepodobné, že zhodnocovaná sekera nebola zhotovená $\mathrm{k}$ bojovému účelu, ale k symbolickej demonštrácii mocenského aspektu premietnutom do popredného postavenia jedinca, resp. jeho rodinného zväzku v danej komunite. Isté je, že vzhl’adom na vek dieta, určený na 3-4 roky, bola sekera k nemu iba dodatočne priložená. Tento moment sa dá vyčítat aj z polohy nezachovanej, no hypoteticky predpokladanej násady. Z umiestnenia sekery totiž vyplynulo, že drevené porisko smero- valo ku krátkej koncovej stene hrobovej jamy, nie $\mathrm{k}$ pravej dlani pochovaného. A navyše, vzhl'adom na vek nemohlo diet’a sekeru plnohodnotnejšie využívat akýmkolvek prípustným spôsobom.

K chronologickej špecifikácii hrobu 8 je smerodajný genetický vztah úzkych sekier typu II Aa k obdobiu avarského kaganátu potvrdený v štúdii F. Szücsiho (2013, 121-123). Nemenej dôležitý je takisto ich výskyt od prelomu 8. a 9. stor. v depotoch, v sídliskovom a pohrebiskovom prostredí (Bartošková 1986, 98-100; Ruttkay, A. 1976, 308). S výnimkou sekery z hrobu 58 v Trnovci nad Váhom-Hornom Jatove (Točík 1971, 142, tab. XXIII: 2) sa zvyšné hrobové nálezy spájajú so starším vel'komoravským horizontom (Hanuliak 2004b, 147). Do tohto časového rámca zrejme patrí aj hrob 8 z Nitry-Dolných Krškán. Hojnejšie ukladanie úzkych sekier do hrobov v mladšom období je menej pravdepodobné (porovnaj Ruttkay, A. 2002, obr. 4) aj pre ukončenie ich výroby a nastúpené zmeny vo vystrojovaní hrobov (Bartošková 1986, 76; Galuška 2006, 26).

\section{Predmety kultového charakteru}

Zástupcovia tejto kategórie $\mathrm{v}$ počte $30 \mathrm{kusov}$ pochádzajú z 20 hrobov (obr. 12: a-g). Podl'a toho tvorí táto skupina medzi hrobmi s pohrebným inventárom diel s hodnotou 52,6\%. Predmety kultového charakteru predstavujú 33,3 \% nálezov z pohrebiska (obr. 5).

V rámci danej kolekcie figurujú celé kusy a ich zlomky s rôznorodým vztahom k posmrtnej potrave a nápojom (keramická nádoba, vedro, mäsitá príloha, vajce) a k amuletom (spona, hrkálka, sekerovitá hrivna). Z predmetnej skladby vyplynie, že ide iba o sedem najčastejšie nachádzaných reprezentantov, zastúpených v obmedzenom počte, pričom začlenenie do príslušných kategórií nie je bezproblémové.

\section{Typ 24 - Keramické nádoby}

(obr. 8: 24)

Vo fragmentoch i v celosti zachované nádoby boli pôvodne uložené v 15 hroboch $(1,3,8,10,11,13,23$, 27, 30, 32, 33, 37, 43, 44 a 46; obr. 12:a-c; tab. I: 1: 1; 3: 1; V: 8: 4; 10: 2; VI: 11: 2; VII: 13: 3; IX: 15: 1; X: 18: 4; XII: 23: 2; XIII: 27: 5; XIV: 30: 1; XV: 32: 1; 33: 5; XVI: 37: 2; XVIII: 43: 2, 3; XIX: 44: 2; 46: 1). Znamená to, že ich zástupcom patrí v danej materiálovej skupine diel s hodnotou $75 \%$. Z hrobu 43 pochádzajú výnimočne dva exempláre, z ostatných jediný kus.

Z d’alšieho hodnotenia vyplynie nerovnomerný výskyt hrobov s označenou prílohou v pohrebiskovom areáli. Ich zástupcovia sa totiž v maximálnej miere zhlukujú v VI. pohrebiskovej skupine, v ktorej nadobudol ich výskyt podiel $58,3 \%$. Z tohto mikro- 

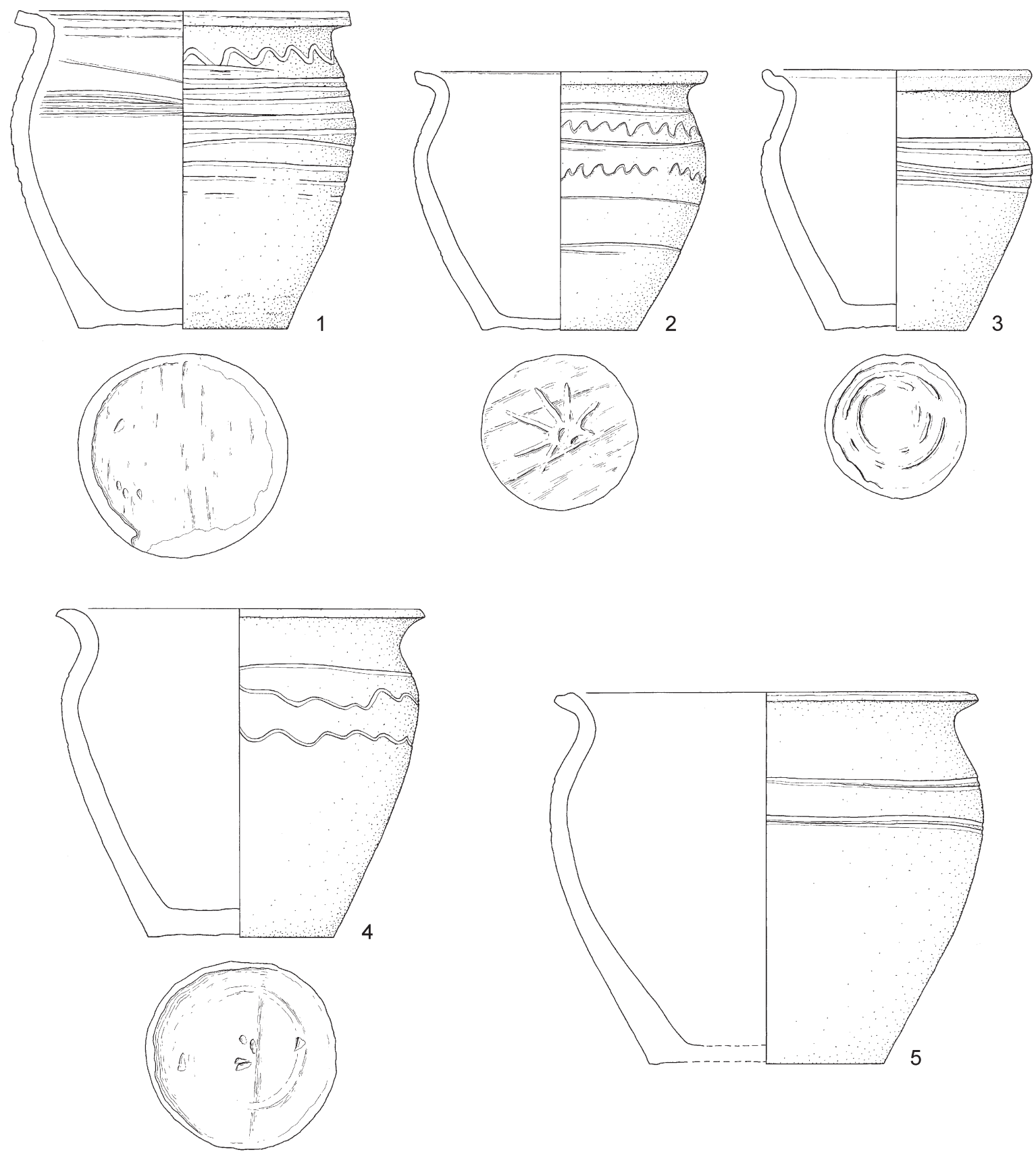

Obr. 10. Nitra-Dolné Krškany. Zástupcovia keramických nádob zo skupiny C.

priestoru s výmerou $89 \mathrm{~m}^{2}$ pochádzajú nádoby zo siedmich z celkove 12 vyhlbených hrobov. V susediacej V. a VII. skupine už išlo iba o dva hroby s podielovou účastou $16,6 \%$ a $22,2 \%$. Po jednom hrobe evidujeme ešte v I., III., IV. a VIII. pohrebiskovej skupine. Avšak z II. skupiny nie je známy ani jediný zástupca (obr. 12: a-c).

Medzi nádobami figurujú iba hrncovité tvary zastúpené $\mathrm{v}$ troch najčastejších formách. Vajcovité varianty s vydutinou v hornej tretine výšky sú v ko- lekcii netradične zriedkavé (hroby 3, 13 a 27; 18,7 \% prípadov). Dominujú, naopak, misovité formy, u ktorých priemer ústia prevyšuje ich výšku (hroby $1,10,11,30,32,37,43,44$ a 46; 56,3 \% prípadov). Zvyšok patrí súdkovitým variantom s vydutinou posunutou do stredného úseku nádob (hroby 23, 33 a $43 ; 25 \%$ prípadov).

Vyhodnocované exempláre sú vymodelované $\mathrm{v}$ ruke z plavenej hliny obohatenej rozdielnym podielom prísad. Na kruhu bývajú dodatočne 
obtočené rôzne vel'ké úseky z horných častí tiel. Na takto upravených plochách býva najčastejšie nanesená rytá výzdoba zložená z pásov vyhotovených hrebeňom s rôznym počtom zubov (37,5\% prípadov) alebo jednoduchých línií vytvorených jednohrotým rydlom.

Prvotnú predstavu o pohrebných zvykoch približuje vztah keramických nádob k zomrelým rôzneho pohlavia a veku. $Z$ analýz plynúca vyššia početnost' detských jedincov s priloženou nádobou $(46,6 \%$ prípadov) voči dospelým mužom ( $20 \%$ prípadov) a ženám (33,3\% prípadov) nevybočuje zo známeho štandardu (Hanuliak/Rejholcová 1999, 82). Akceptovatel'ný je takisto rozhodujúci podiel najvšestrannejšie využitelných nízkych nádob dominujúcich nad obmedzeným počtom stredne vysokých zástupcov prevyšujúcich $151 \mathrm{~mm}$. Výsledky d’alších analýz napriek tomu ukázali, že u detských jedincov nadobudli spriemerované miery hodnotu $126 \mathrm{~mm}$, u dospelých žien $138 \mathrm{~mm}$, u mužov $143 \mathrm{~mm}$. K nim patria takisto nádoby z hrobov 8,43 a 44 vysoké 155-165 cm (tab. XVIII: 43: 3; XIX: 44: 2).

Podla týchto hodnôt sa medzi nádobami z rovnakej vel'kostnej skupiny vyskytovali väčšie i menšie tvary. Ich objem sa mal podla teoretického odhadu blížit k množstvu jednorazovej dávky potravy konzumovanej príslušnými jedincami. Aj z tohto dôvodu sa nepreukázal v globále zaznamenávaný prejav častejšieho prikladania vyšších nádob s väčším objemom do hrobov dospelých žien. Tie zvyčajne patrili k precíznejšie vyrobeným exemplárom kuchynskej keramiky využívaným k príprave varených jedál pre príslušníkov rodinného zväzku (Hrubý 1965, 265; Pavlů 1971, 85). Na dolnokrškanskom pohrebisku sa tri najvyššie nádoby ocitli pri dvoch dospelých mužoch a detskom jedincovi staršieho veku mužského pohlavia.

Väčšiu mieru pragmatického prístupu v uplatňovaných výberových kritériách možno potvrdit v prípade už opísaných variantov hrncovitých tvarov. Aj preto je vcelku pochopitelný výrazný podiel nižších misovitých nádob (83,3\% prípadov), vhodnejších na konzumáciu kašovitých jedál, doložený v hroboch detí. U dospelých mužov a žien sú zasa vo vyrovnanom pomere zastúpené hrncovité nádoby vajcovitej, súdkovitej i misovitej formy. Môže to byt' aj preto, lebo skladba tvarov poskytovala možnost’ priložit k zomrelým širšiu škálu jedál (Budinský-Krička 1959, 19; Frolíková-Kaliszová 2009, 95, 97; Justová 1990, 63; Marešová 1983, 43, 44; Profantová 2015, 27).

K ozrejmeniu predpokladaného významu môže prispiet’ objem nádob spresnený pomocou piesku plneného po líniu s maximálne zúženým hrdlom. Vyčíslené údaje s prekvapivo obmedzeným rozptylom členia nádoby do troch skupín. Najpočetnejší sú reprezentanti s nízkym objemom
(0,4-0,52 1) pochádzajúci z hrobov 3, 10, 11 13, 30, 33, 43 a 46 so štyrmi detmi a dvomi dospelými mužmi i ženami.

Do zriedkavejšie zastúpenej druhej skupiny patria nádoby s priemerným objemom $(0,9-1,06 \mathrm{l})$ uložené v hroboch $1,8,23,27,30$ a 37 k dvom detom a trom dospelým ženám. Nádoby s najväčším objemom (1,82-1,85 1) sa vyskytli iba u dospelých mužov z hrobu 43 a 44 vyhĺbených $\mathrm{v}$ tesnom susedstve $\mathrm{v}$ okrajovej časti VI. pohrebiskovej skupiny. K objasneniu tohto zistenia je potrebné uviesț, že tieto nádoby zrejme neboli využité ako pevný obal pre posmrtnú potravu. Poslúžili pri obradnom umývaní pochovaných, a preto museli byt’ zámerne rozbité (Bednárik 1939, 61; Jágerová 2001, 16; Krumphanzlová 1972, 200). V hrobe 43 bola na posmrtnú prílohu predurčená súdkovitá nádoba s objemom 0,44 1 .

Z predchádzajúcich poznatkov vyplynuli pochybnosti o tom, že by sa vel'kost' keramických nádob dôslednejšie prelínala s pohlavím a vekom zomrelých. Pozoruhodnejší je štandardizovaný objem dosiahnutý aj na nádobách s rozdielnymi výškovými parametrami. Znamená to, že zhotovitelia nádob mali dostatočné skúsenosti, aby vedeli vyrobit exempláre s požadovaným objemom, hoci sa porovnávaní reprezentanti líšia od seba vo viacerých zložkách.

Podla d’alšieho zistenia neboli keramické nádoby nachádzané $\mathrm{v}$ jednotnej polohe pri pochovanom, ale $\mathrm{v}$ takmer vyrovnanom pomere $\mathrm{v}$ troch tradičných sektoroch. K nim patrí širšia oblast' pravého (tab. XIII: 27; XIV: 30; XVIII: 43) či lavého chodidla (tab. V: 10; VI: 11; XV: 35; XVI: 37) a pozícia konča nich (hrob 1, 3). Žiadna z nich nebola uprednostnená $\mathrm{v}$ prípade istého pohlavia a vekovej skupiny, ani pri umiestňovaní rozdielnych keramických tvarov odlišnej vel'kosti. K predchádzajúcim prípadom nebola pripojená nádoba stojaca výnimočne pri pleci dospelej ženy v hrobe 23, ani v hrobe 13 druhotne presunutý exemplár pri telesných zvyškoch detského jedinca.

Vo väčšinových prípadoch ide o tri štandardné sektory, ktoré sa vylučujú s priestormi s najčastejším umiestňovaním predmetov dennej potreby a nástrojov. Aj kvôli tejto okolnosti neboli každodenne využívané keramické nádoby začlenené do označenej skupiny. Navyše, ich prednostné využitie $\mathrm{v}$ podobe trvácnych obalov posmrtnej potravy a nápojov zaraduje exempláre tejto kategórie medzi predmety kultového charakteru. Do rovnakých miest prikladali pozostalí takisto aj iné potravinové články v podobe mäsitej prílohy, vajec a nápojov plnených do drevených vedier.

Odlišné poslanie napíňali tri nádoby zachované vo fragmentoch. $Z$ ich umiestnenia sa dá vyčítat', že k rozbitiu nádob nedošlo náhodne, ale 


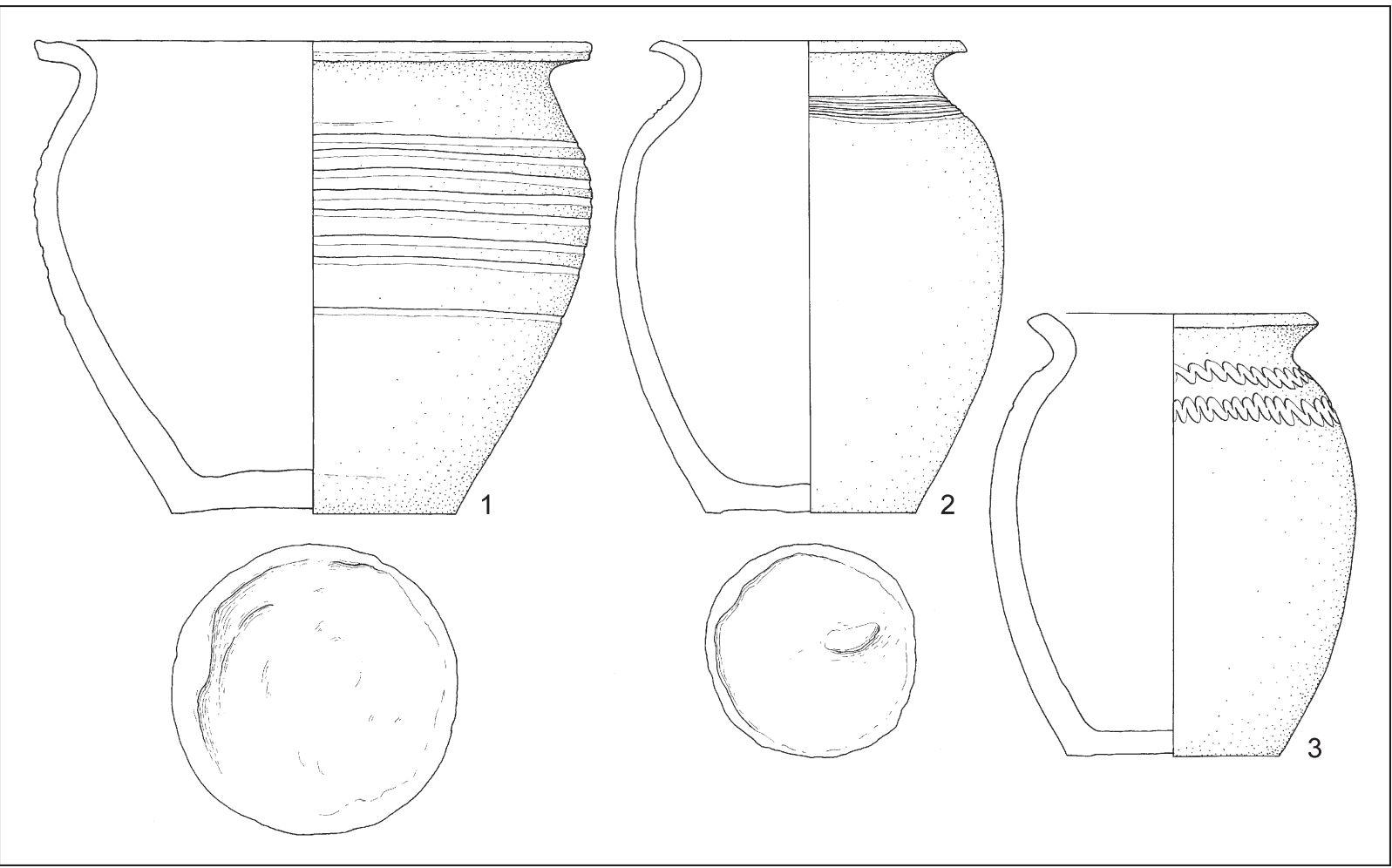

Obr. 11. Nitra-Dolné Krškany. Zástupcovia keramických nádob. 1 - nádoba zo skupiny C; 2, 3 - nádoby zo skupiny B.

z konkrétnych príčin. Zatial' čo sa v hroboch 43 a 46 (tab. XVIII: 43; XIX: 44) s dospelými mužmi keramické tvary rozbili po ich vhodení na dno hrobu, nádobu z hrobu 32 (tab. XV: 32) s dospelou ženou rozbili pozostalí mimo tento priestor. Získané črepy sa do zásypovej výplne hrobovej jamy vhadzovali postupne. $Z$ nich iba jediný sa ocitol pri pochovanej. Ostatné časti z vyšších úrovní zásypu sa z neho nekontrolovane odstránili počas archeologického výskumu. Rozmery tohto fragmentu boli napriek tomu dostačujúce, aby sa pôvodný tvar nádoby mohol plnohodnotne kresbovo zrekonštruovat'.

Chýbajúce uhlíky a zvyšky popola nachádzané na pohrebisku vo Vel'kom Grobe a Nitre-Lupke (Chropovský 1957, 220; 1962, 203) nepripúštajú využitie spracúvaných nádob pri profylaktickom vydymovaní hrobových jám. $S$ väčšou istotou sa dá uvažovat’ o ich spojení s iným prejavom očistného aktu spočívajúceho v obradnom umývaní tela zomrelého. K tomuto účelu využité nádoby museli byt po akte zámerne zničené, pretože prišli do styku s nečistým zomrelým. Potvrdením opodstatnenosti vykonávania tohto zvyku iba $\mathrm{v}$ istom rodinnom zväzku je poloha všetkých troch hrobov umiestnených v tesnom susedstve na okraji VI. pohrebiskovej skupiny (obr. 12).

Detailnejšie informácie o nádobách možno získat z porovnávania vizuálne zaznamenávaných zložiek v ich vzhlade, skladbe keramickej hmoty a výrobných postupoch. Podla nich sa dajú spracúvané exempláre začlenit do troch skupín. V prvej z nich, označenej ako skupina $A$, figurujú zástupcovia s prejavmi nižšej kvality získané z hrobov 3, 10, 23 a 33 (obr. 12: a; tab. I: 3: 1; V: 10: 2; XII: 23: 2; XV: 33: 5). Túto okolnost' zaznamenáva index spriemerovanej masívnosti stien kulminujúci pri hodnote 5,1. Tento údaj vyrátaný z podielu výšky a váhy je na lokalite najvyšší.

K signifikantným prejavom patrí mierna prevaha nižších súdkovitých foriem so zaobleným okrajom, s obtočeným krátkym úsekom hrdla, ktoré sa dajú polahky zhotovit pri ručnom modelovaní. V keramickej hmote sa vyskytuje vyšší podiel hrubého piesku so stredne vel'kými až vel'kými kamienkami. Po výpale nižšej kvality nadobudli steny čiernohnedé sfarbenie s drsnou štruktúrou povrchu. Výzdoba tradičnými motívmi bola nanesená jednoduchým rydlom i hrebeňom s tromi alebo piatimi zubmi. Výnimočným variantom sú dva pásy nepravidelných vlnoviek zostavené z husto zoradených hrebeňových vpichov zaznamenaných na nádobe $\mathrm{z}$ hrobu 33 (tab. XV: 33: 5). Nezvyčajné je takisto nadmerne zhrubnuté dno nádoby misovitej formy $\mathrm{z}$ hrobu 10, na ktorom bol z hrnčiarskej podložky odtlačený plastický kruh s priemerom $20 \mathrm{~mm}$. V tomto hrobe pochovali detského jedinca stredného veku, vo zvyšných dvoch dospelých mužov a ženy. 
Zástupcovia zo skupiny B boli uložení v hroboch 8, 13, 27, 32 a 43 (obr. 12: b; tab. V: 8: 4; VII: 13: 3; XIII: 27: 5; XV: 32: 1; XVIII: 43: 2). Ich charakteristiky vystihuje priemerne zvládnutá výrobná kvalita s pestrejšou skladbou určujúcich znakov. K príznačným prejavom patrí znížená hrúbka stien, premietnutá do nižšieho indexu masívnosti s hodnotou 4,45, častejší výskyt kuželovito zrezaného okraja i dodatočné obtočenie hornej štvrtiny až tretiny nádoby. Výzdobné motívy nanášané hrebeňom $\mathrm{s}$ tromi až štyrmi zubmi sú o málo častejšie ako línie vyhotovené jednohrotým rydlom. K výnimočnostiam patria pásy zostavené z krátkych šikmých a vodorovných vrypov pokrývajúce väčšiu čast tela nádoby z hrobu 13 (tab. VII: 13: 3). V keramickej hmote figuruje priemerné množstvo hrubého i jemného piesku. Povrch stien nadobudol po kvalitnom výpale tmavohnedú farbu. Na minimálne vyklenutom dne nádob z hrobov 8, 13 a 27 (tab. V: 8: 4; VII: 13: 3; XIII: 27: 5) možno nájsț iba obvodový prstenec odtlačený z podložky hrnčiarskeho kruhu vyplnený s málo zretel’nými odtlačkami drevenej štruktúry podložky pracovnej dosky (Fusek 2009, 99, 102).

Súčastou tejto skupiny sú vyššie spomenuté nádoby $\mathrm{z}$ hrobov 8 a 43 (obr. 11: 2, 3; tab. V: 8: 4; XVIII: 43: 2) s viacerými príbuznými prvkami v skladbe keramickej hmoty, výpale, farebnosti povrchu a v hrnčiarskom rukopise doplnené identickou váhou. Rozdiel sa zaznamenal v aplikovanom výzdobnom motíve vyhotovenom jednohrotým rydlom. Úzkohrdlé nádoby tohto typu, označené E. Fottovou $(2019,165,166)$ ako typ H21 sa rozpoznali v menšinovom zastúpení na nitrianskych lokalitách Pod Zoborom, Lupka a Tržnica.

Do skupiny $\mathrm{C}$ bol zaradený najvyšší počet exemplárov uložených do hrobov 1, 30, 37 43, 44 a 46 (obr. 12: c; tab. I: 1: 1; XIV: 30: 1; XVI: 37: 2; XVIII: 43: 3; XIX: 44: 2; 46: 1). Ich reprezentanti sa vyznačujú vyššou kvalitou i niektorými progresívnymi prvkami (obr. 10: 1-5; 11: 1). Okrem dôkladne preplavenej keramickej hmoty s nízkym podielom jemného či hrubého piesku k nim patria zahladené stopy po nálepovej technike $\mathrm{s}$ dodatočne obtočenou hornou tretinou až polovicou tvaru. Horná strana ústia zo štyroch nádob je prežliabnutá, v okrajovej profilácii prevláda kuželovité, výnimočne i zvislé a lievikovité zrezanie. Vo výzdobe vyhotovenej jednohrotým rydlom prevládajú priame línie nad ich kombináciou s vlnovkami.

Povrch misovitých tvarov nadobudol po kvalitnom výpale hnedé sfarbenie s občasným ružovým nádychom. Na vyklenutých dnách figurujú odtlačky štruktúry drevenej podložky hrnčiarskeho kruhu s obvodovým prstencom a občasnou piesčitou podsýpkou s obilnými zrnkami (tab. I: 1: 1; XVI: 37: 2; XIX: 44: 2). Na dne z hrobu 30 vystupuje regu- lárna plastická značka slnečného motívu s ôsmimi lúčmi (tab. XIV: 30: 1). V hrobe 46 ide zasa o dva sústredné kruhy v obvodovom prstenci, v hrobe 37 je zobrazený iba jeden kruh (tab. XVI: 37: 1).

Analýza sledovaných prvkov príbuznej kvality poskytla indície $\mathrm{k}$ rámcovému datovaniu keramických nádob. Exempláre zo skupiny $\mathrm{C}$ by podla prežliabnutej hornej strany ústia, zaznamenanej u nádob z hrobov 30, 43, 44 a 46 mali patrit do mladšieho vel'komoravského horizontu (Dostál 1975, 163, 164; Klanica 1970, 104; Macháček 2001, 138, 142; Mazuch 2013, 57, 58). Takúto možnost' pripúšta koncentrácia hrobov s ich výskytom v V., VI. a VII. skupine z východnej časti pohrebiska. Hrob 1 je výnimočne odsunutý do III. skupiny (obr. 12: a). Pohrebný inventár potrebnú oporu $\mathrm{k}$ datovaniu poskytnút nemôže, pretože jeho zložky v hrobe 30 a 46 zjavne absentujú, do hrobov 43 a 44 boli priložené nože a vajce.

V hroboch s nádobami zo skupiny B sú prílohy početnejšie. Dôležitá je najmä sekera, gombík so zvislo rebrovaným povrchom z pozláteného bronzového plechu, vedro a príloha mäsitej potravy z hrobov 8 a 13. Podla ich kombinácie mohli byt hroby vyhíbené azda už $\mathrm{v}$ staršom horizonte. $\mathrm{V}$ rámci neho sa totiž vyšší sociálny status zomrelých prezentoval identickým spôsobom. Jednoduchú krúžkovú náušnicu a krúžkovú náušnicu s uzlíkom dopĺňa v hrobe 27 iba praslen. Tieto predmety majú zanedbatel'nú datovaciu schopnost'.

Z polohy týchto hrobov v V.-VII. skupine však nemožno vylúčit ani mladšie datovanie. Uvedená eventualita je aktuálna $\mathrm{v}$ prípade súdkovitých nádob so zúženým hrdlom z hrobov 8 a 43, ktoré okrem miestnej výroby spája E. Fottová (2019, 161, 164), s mladším vel'komoravským horizontom. Do záverečnej etapy ich vývojovej línie patria aj nádoby z hrobov 16 a 24 pohrebiska v Nitre-Horných Krškanoch zaradené do začiatku 10. stor. (Hanuliak/ Chropovský 2019, tab. III: 16: 4; V: 24: 2).

Nádoby zo skupiny A, priložené k jedincom s nanajvýš priemerným sociálnym statusom, sa vyznačujú prvkami nižšej kvality. To však neznamená, že uvádzané indikátory radia príslušné hroby na lokalite jednoznačne do staršieho úseku pochovávania. Uvedenú možnost' nenapíňajú ani dve krúžkové náušnice s náušnicou s dvojkónickým granulovaným záveskom, zlomok noža a praslen. Nízka úroveň rozpoznaných prvkov nastoluje otázku, či nemôže ísț o exempláre účelovo zhotovené $\mathrm{k}$ uloženiu do hrobov. Pri riešení chronologickej špecifikácie keramických nádob zo všetkých troch skupín by sa nemal prehliadnut koncentrovaný výskyt zástupcov z kategórie A v VI. pohrebiskovej skupine, kde vystupujú spolu s dvomi nádobami zo skupiny $\mathrm{B}$ a inými dvomi exemplármi zo skupiny C (obr. 12). 


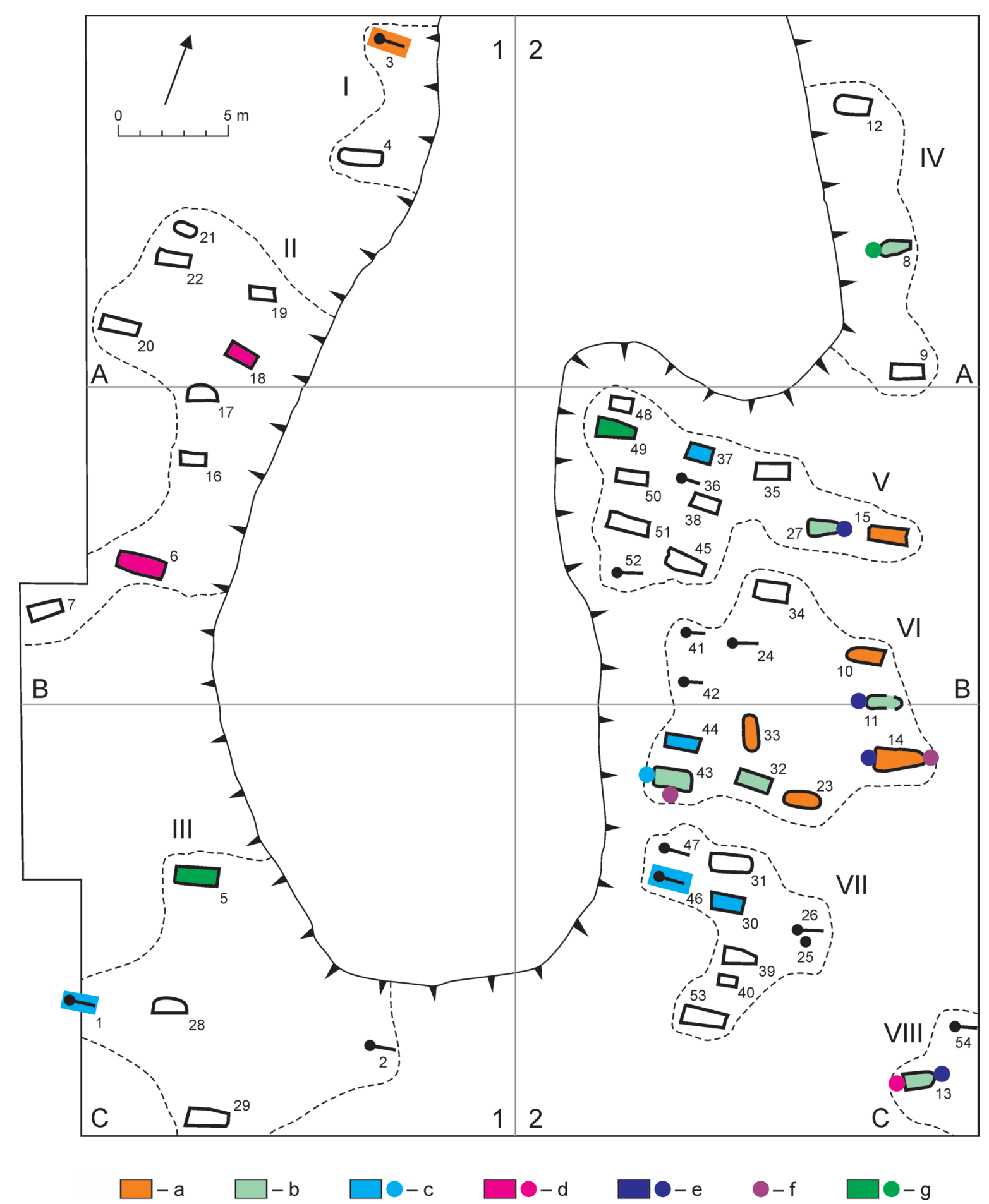

Obr. 12 Nitra-Dolné Krškany. Rozmiestnenie hrobov s predmetmi kultového charakteru. Legenda: a - keramická nádoba zo skupiny A (typ 24); b - keramická nádoba zo skupiny B; c - keramická nádoba zo skupiny C; d - vedro (typ 25); e - mäsitá príloha (typ 26); f - vajce (typ 27); g - amulet (typ 28-30).

Ani do jednej z troch sformovaných skupín sa pre niektoré špecifické prejavy nedala $\mathrm{v}$ počiatočnej fáze analýz začlenit nádoba z hrobu 11 (tab. VI: 11: 2). Rozhodujúci je z nich tvar pozostávajúci z krátkeho ústia napojeného na zalomené hrdlo pod uhlom, ktorý je o $10-11^{\circ}$ vyšší ako u ostatných zástupcov. Neobvyklá je takisto ostro zalomená línia maximálnej vydutiny. Ďalším špecifickým znakom je iba rukou docielené dôkladné zahladenie povrchu, dodatočné obtočenie na rotujúcej podložke chýba. Aj preto prekvapí pre hrnčiarsky kruh typická regulárna značka stvárnená v po- 


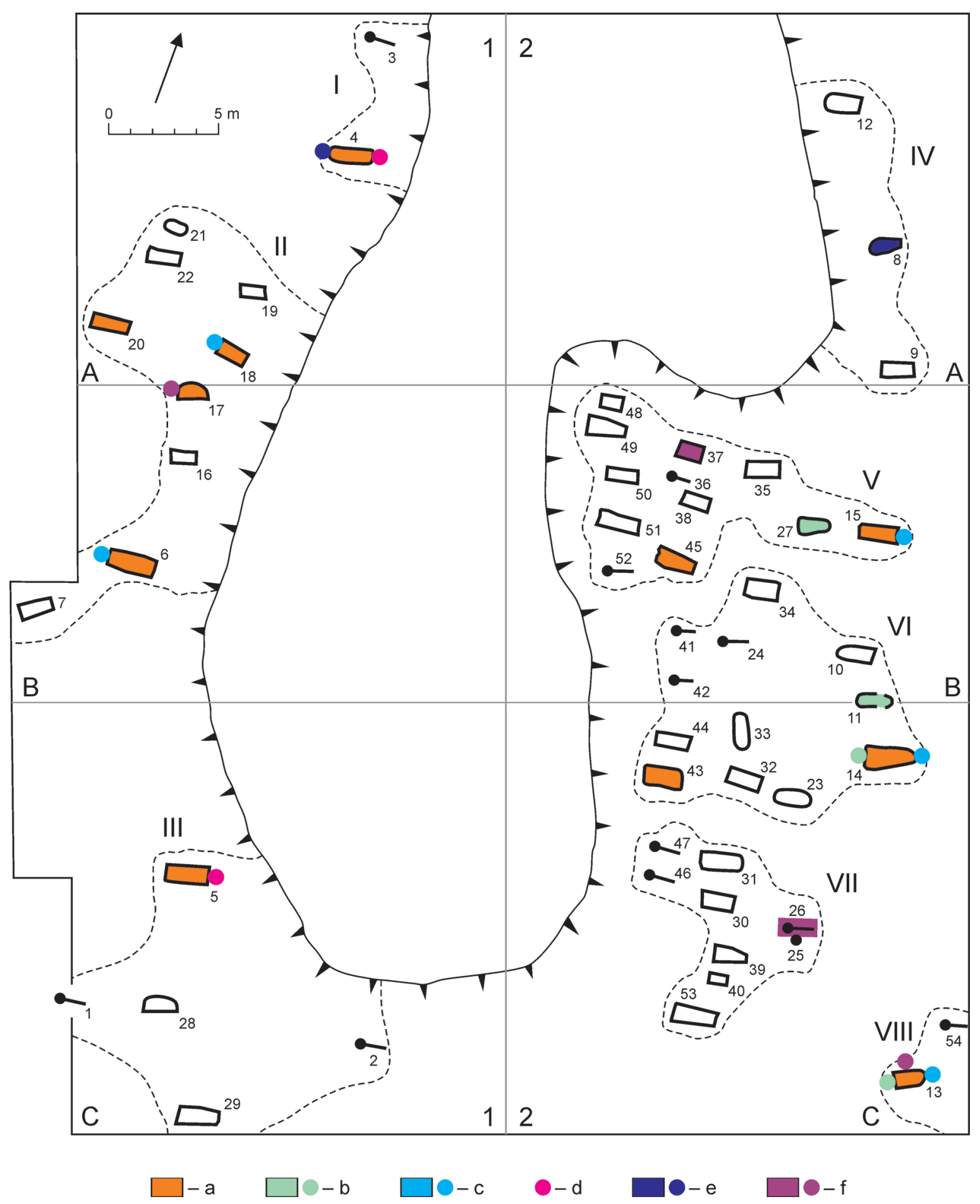

Obr. 13. Nitra-Dolné Krškany. Rozmiestnenie hrobov so sledovanými prvkami. Legenda: a - nadpriemerný objem hrobovej jamy; b - mäsitá príloha (typ 26); c - vedro (typ 25); d - britva (typ - 16); e - zbraň (typ 22, 23); f - súčasti odevu (typ 12-14).

dobe svastiky na vyklenutom dne (tab. VI: 11: 2). Okrem hrobu 19 z Nitry-Lupky (Chropovský 1962, tab. 22: 5), ju zaznamenávame aj na nádobe $\mathrm{z}$ hrobu 10 v Ipel'skom Sokolci (Vendtová/Rejholec 1963, 63, obr. 4: 4), hrobu 43 zo Svätého Petra (Béreš 1995, 119, obr. 23: 12) a z hrobu 493 v Trnovci nad Váhom-
-Hornom Jatove (Točík 1971, 177, tab. XLIII: 16). Na dolnokrškanskej nádobe sa takisto zaznamenalo neobvyklé okrovožlté sfarbenie povrchu. Podla výsledného indexu masívnosti stien s hodnotou 4,18 by sa tento exemplár po patričnom zvážení mohol nakoniec pripojit k zástupcom zo skupiny B. 
V tejto kolekcii sa totiž takisto vyskytla misovitá forma, rovnako tak aj výzdobný dekór nanášaný viaczubým hrebeňom.

\section{Typ 25 - Vedrá}

(obr. 8: 25)

Medzi včasnostredovekými drevenými nádobami sú v nadmernom počte zastúpené vedrá odlišsitelné od ostatných typickými zložkami. Patria k nim železné držadlá so závesnými kovaniami a obručami zvierajúcimi drevené dyhy s rovným dnom. Ich zástupcovia pochádzajú z piatich hrobov $(6,13$, 14, 15 a 18; tab. III: 6: 2; VII: 13: 4; XIII: 14: 7; IX: 15: 2; X: 18: 4) umiestnených v II., V., VI. a VIII. pohrebiskovej skupine (obr. 12: d; 13: c).

V kolekcii nádob z Dolných Krškán patrí uvedeným zástupcom diel s hodnotu 23,8 \%, zvyšok doplnajú keramické tvary. Okrem špecializovaných výrobných postupov mohol získaný nepomer ovplyvnit zúžený rozsah ich využívania zredukovaný na manipuláciu s nápojmi a inými tekutinami.

Doplnenie d’alších funkčných eventualít $\mathrm{v}$ pozemskom svete, priblíženie výberových kritérií uplatňovaných pri ich umiestňovaní do hrobov st’ažuje dekompozícia drevených a zlomkovitý stav železných dielcov. Kompletnejšie zachované vedrá sú zriedkavé. O to cennejšie sú prípady, vd’aka ktorým môžu byt tieto exempláre po precíznom zdokumentovaní nájdených zlomkov následne zrekonštruované do predpokladaného vzhl'adu i rozmerov. Na základe vykonanej kresbovej rekonštrukcie mali všetky zhodnocované vedrá kruhovú dispozíciu s kuželovitou formou korpusu doplnenú trojicou obručí a príslušnými závesnými súčastami. Doklady o pokrytí povrchu železným plechom chýbajú.

Po odrátaní hrúbky dýh z vonkajšieho priemeru a zrekonštruovaní vnútornej výšky sa na podklade skompletizovaných metrických údajov vyčíslil objem príslušných nádob. Podla neho sa ich zástupcovia stotožňujú s keramickými nádobami nízkych tvarov. K nim patria exempláre z hrobu 13 a 18 s objemom 1,95 1 a 1,46 l. Najmenší objem 0,73 1 malo vedro z hrobu 14 . Naproti tomu v hroboch 6 a 15 objem vedier vystúpil na 2,2 1 a 2,5 1. Uvedenú kubatúru spätú už s vysokými keramickými nádobami nemal ani jediný exemplár z dolnokrškanského keramického súboru.

Ako v prípade keramických nádob, tak aj u vedier sa analýzami nepotvrdil priamy vztah medzi ich objemovými hodnotami a pohlavím i vekom pochovaných. Exemplár s najnižším objemom priložili pozostalí do hrobu $14 \mathrm{~s}$ dospelou ženou. $V$ hroboch 13 a 18 boli pochované dve deti. Iba vedrá s najvyš- ším objemom ležali v hroboch 6 a 15 pri dospelom mužovi a žene.

Z typologického hladiska sa u zhodnocovaných nádob vyskytuje niekol'ko príbuzných, odlišných i špecifických prvkov. Do prvej skupiny patria držadlá zo železnej tyčinky štvorhranného, výnimočne aj kruhového prierezu s priemerom $2,2-7 \times 2,5-6 \mathrm{~mm}$. Ich vonkajší priemer v rozsahu 120-165 mm býva prispôsobený vel'kosti hornej obruče. Jej vyklenutie osciluje od $62 \mathrm{~mm}$ do $85 \mathrm{~mm}$. Oblúkovito prehnuté koncové úseky držadiel z hrobov 14, 15 a 18 sú iba mierne zhrubnuté. Gombíkovito rozkuté konce poznáme z hrobov 6 a 13 .

Odlišné prvky sú tradične zaznamenávané u závesných kovaní. V častejšie uprednostňovanej doštičkovitej verzii sa vyskytuje lichobežníkovitý (tab. VII: 13: 4) a pásikový typ (tab. VIII: 14: 7; IX: 15: 2). V jedinom exemplári je doložený motív obráteného písmena T (tab. III: 6: 2) a kotvovito rozoklaná forma (tab. X: 18: 4).

Viac kombinácií evidujeme v prípade opakovaného výskytu troch obručí spájaných jedným až dvomi nitmi. Medzi zaznamenanými možnostami figuruje šírka pásikov pozvolne narastajúca od ústia $\mathrm{k}$ dnu. Na dvoch nádobách je menej exponovaná stredná obruč užšia. Popri úzkych obručiach so šírkou 6-8 mm sú známe aj stredne široké s rozmedzím 9-19 mm. Naproti tomu sú obruče na vedre z hrobu 13 široké $17 \mathrm{~mm}, 45 \mathrm{~mm}$ a $47 \mathrm{~mm}$. Ich odolnost' voči silovému pnutiu zvyšujú na strednej a dolnej obruči falcovito ukončené okraje. Na viacerých úsekoch z ich povrchu sa zachovali koróziou petrifikované odtlačky textilného zábalu.

K špecifickým prvkom nesporne patria štyri krížové kovania pripevnené $\mathrm{k}$ drevenému korpusu štvoricou nitov. $Z$ ich polohy sa nedá vyčítat pôvodné poslanie. Prijatelnejšia je kombinácia snahy o skvalitnenie upevnenia hornej obruče, súčasne i zvýšenie estetického dojmu z tohto vedra (Hrubý 1955, 157). S istotou sa nedá zamietnut ani prípadný náboženský kontext objavujúci sa v latentnej podobe aj na iných reprezentantoch materiálnej kultúry (Hanuliak/Pieta 2014, 143-148). Opísané riešenie nie je natol'ko výnimočné, aby sa nedalo aplikovat’ aj na iných výrobkoch tohto typu. V skutočnosti identické prípady nie sú známe. $\mathrm{K}$ takýmto prípadom nepatria vedrá z Mikulčíc a Starého Města-Na Valách, u ktorých príbuzný krížový motív ukončoval závesné kovania (Bartošková 1986, obr. 17: A: 3; Galuška 2017, 39, 191). Iný špecifický prvok predstavuje krúžok s priemerom $25 \mathrm{~mm}$ pripevnený nitom nad strednou obručou. Podla polohy mohol tento krúžok zabezpečit lepšiu stabilitu vedra počas jeho prenosu či prevozu (Hrubý 1955, 158, tab. 51: 3).

Analýza postrehnutelných zložiek z piatich vedier zo spracúvanej nekropoly nebola samoú- 
čelná. Jej výsledky poskytli viacero informácií. Zvýšená pozornost’ spomedzi nich patrí nadmernej rôznorodosti spochybňujúcej zhotovovanie vedier jediným výrobcom. Ak, pravda, nie je metodicky nesprávne hladanie jednotnejšieho rukopisu istého remeselníka s častejšie opakovanými príbuznými až identickými prejavmi, ako to býva pri keramických nádobách.

Na základe akceptovatelných datovacích schopností určujúcich prvkov, vybraných z množstva protichodných názorov, možno s prípustnou dávkou tolerancie posunút do staršieho vel'komoravského horizontu vedro z hrobu $6 \mathrm{~s}$ kotvovito rozoklaným závesným kovaním. $\mathrm{K}$ nemu sa dá pripojit vedro z hrobu $18 \mathrm{~s}$ kovaním v tvare obráteného písmena T. Pásikové kovania s prerazeným otvorom sú už zrejme späté s mladším horizontom (Bartošková 1986, 94; Galuška 1996, 107; Klanica 2006a, 72, 73; Kouřill Tymonová 2013, 127). V prípade prvých dvoch hrobov môže chronologické zaradenie podporit aj ich umiestnenie $\mathrm{v}$ západnej časti nekropoly.

Drevené vedrá so železnými súčastami sa vo všeobecnosti považujú za jeden $\mathrm{z}$ indikátorov prestížnej pozície príslušných jedincov v miestnej komunite. Zvyčajne sa pritom zohladňuje ich náročnejšia remeselná výroba, očakávaná predurčenost’ takýchto nádob $\mathrm{k}$ uskladňovaniu nielen vody ale aj hodnotnejších nápojov, ako aj v globále potvrdený výskyt $\mathrm{v}$ hroboch dospelých mužov s militáriami, nadpriemernými rozmermi hrobových jám a ich úpravami drevom (Hanuliak 2004b, 191, 192; Poláček/ Marek/Skopal 2000, 185; Profantová 2015, 51, 69).

Na spracúvanej nekropole nie sú však určujúce ukazovatele reprezentatívne zastúpené. Medzi jedincami figurujú dve dospelé ženy, dvaja detskí jedinci, no iba jediný dospelý muž. Objem vedier nekorešponduje s ich vekom, čo oslabuje priamejší vztah nádob k pochovaným. Pri dospelých ženách stredného veku sa našla nádoba s najmenším i najväčším objemom $(0,731$ a 2,51). Dieta s najnižším vekom malo $\mathrm{v}$ hrobe napriek tomu vedro s objemom 2 litre. To je iba o málo menej ako u dospelého muža. Aj väčšinovo zaznamenané polohy z okolia dolných úsekov hrobových jám podporujú názor o prikladaní takýchto exemplárov k už ležiacim telám pozostalými príslušníkmi rodinných zväzkov.

Pozitívne svedectvo k demonštrácii vyššej spoločenskej úrovne poskytujú híbky kulminujúce pri hodnote $200-210 \mathrm{~cm}$ a objemové parametre od $3 \mathrm{~m}^{3}$ po $5,4 \mathrm{~m}^{3}$. Menej adresné sú občasné prílohy mäsitej potravy, dve strieborné náušnice $\mathrm{s}$ jednostranným granulovaným záveskom a gombík so zvislo rebrovaným povrchom $\mathrm{z}$ pozláteného bronzového plechu. Osamotenému nožu chýbajú výstižnejšie hodnotové prvky. V prípade dalšieho exemplára s parohovinovou rukovätou je naznačená súvislost’ dostatočne informatívna. Po zohladnení uvedených prejavov nemožno dreveným vedrám upriet schopnost' náznakovej indikácie sledovaného vztahu, aj ked' k jej potvrdeniu chýbajú ustálené a pohrebnými zvykmi neskreslené indikátory.

\section{Typ 26 - Mäsitá príloha}

(obr. 8: 26)

Zvieracie kosti sa našli $\mathrm{v}$ štyroch hroboch (11, 13, 14 a 27; tab. III: 6; VI: 13; VIII: 14; X: 18; XIII: 27) patriacich do V., VI. a VIII. pohrebiskovej skupiny, pričom hroby 11 a 14 boli vyhíbené v VI. skupine (obr. 12: e). Prekvapujúco pôsobí pozícia všetkých štyroch hrobov umiestnených do líniovej zostavy vo východnom úseku pohrebiska. Predmetné hroby dotvárajú v súbore diel 7,4\%. Podla toho sa lokalita pripája k pohrebisku z Čakajoviec (Rejholcová 1995a) a Vel'kého Grobu (Chropovský 1957) s ovela vyšším počtom preskúmaných hrobov.

Zaujímavé sú takisto poznatky, ktoré vo svojom posudku uviedol C. Ambros z Archeologického ústavu SAV. Podla neho všetky nájdené kosti pochádzajú z kury domácej (Gallus gallus dom.) - sliepky. $\mathrm{Z}$ ich skladby možno usúdit, že tieto exempláre museli byt do hrobov umiestňované s mäsitými častami. I preto je vhodnejšie označovat ich za prílohy mäsitej potravy doplńajúce tradičné potravinové prílohy a nápoje umiestňované $\mathrm{v}$ keramických nádobách a vedrách.

Ďalšie zaujímavé skutočnosti vzídu z posudzovania vztahu predmetných kostí $\mathrm{k}$ jedincom rozdielneho pohlavia a veku. Okrem dvoch dospelých žien stredného veku dopĺñajú kolekciu aj dve deti, dospelý muž chýba. A to aj napriek tomu, že sa títo jedinci vyskytujú na každej nekropole z územia Slovenska. V globálnych hodnotách (Hanuliak 2004b, 193) dokonca s podielom $46,9 \%$ dominujú nad ženami $(27,8 \%)$ a detmi $(25,3 \%)$. Príkladom je čakajovské pohrebisko s podielom príloh u mužov a žien v pomere $77,8 \%$ voči $22,2 \%$. Inak je to vo Vel'kom Grobe, na ktorom detskí jedinci $(44,5 \%)$ počtom prevyšujú dospelé ženy (33,3 \%) a mužov (22,3\%).

Opodstatnenost' stotožňovania kostí so zvyškami mäsitej potravy vyplýva na spracúvanej lokalite $z$ vel'kosti dielov uložených $k$ jedincom rozdielneho veku. Príkladom sú tri kosti z končatiny nájdené pri dietati najmladšieho veku $\mathrm{z}$ hrobu 13. Pri dietati stredného veku z hrobu 11 sa ku končatine pripájala prsná časṫ. Z hrobov 14 a 27 dospelých žien pochádzajú podla ôsmich kostí kompletnejšie mäsité diely sliepok.

Podla toho pristupovali pozostalí k výberu mäsitých pokrmov s logicky usmernenými zásadami. Menej preukazné je $\mathrm{v}$ tomto smere umiestnenie kostí. S najobvyklejšie doloženým priestorom 
uskladňovania potravinových príloh a nápojov v okolí chodidiel (36,6 \%) sa stotožňuje iba situácia z hrobu 27. V hroboch 11, 13 a 14 sa s pozoruhodným stereotypom opakuje pozícia stredného úseku lavej steny hrobovej jamy. Napriek tomu, že vo všeobecnosti býva táto poloha zastúpená v 22, $5 \%$ prípadov, nepoznáme dôvody jej uprednostňovania spomedzi iných 32 miest z priestoru hrobovej jamy (Hanuliak 2004b, 194).

$\mathrm{Z}$ dostupného pramenného fondu sa nedajú vyčítat doklady, pre ktoré bola príloha mäsitej potravy umiestnená iba k týmto a nie k iným jedincom. $\mathrm{K}$ nim by mal podla sprievodných prejavov patrit dospelý muž z hrobu $5 \mathrm{~s}$ britvou, jedinec z hrobu 4 uložený na doskovej podložke s britvou a kopijou a diet’a stredného veku $\mathrm{z}$ hrobu 8 so sekerou. Súčasne treba uznat, že sa podla rozmerov hrobových jám a pohrebného inventára hrob 14 dospelej ženy a hrob 13 dietata najmladšieho veku oprávnene ocitajú na najvyššom mieste vo svojej kategórii. Okrem strieborných náušníc má určujúci význam gombík so zvislo rebrovaným povrchom a príloha vedra. Naopak, $\mathrm{k}$ diet’atu stredného veku z hrobu 11 a dospelej žene z hrobu 27 boli priložené keramické nádoby, resp. náušnice podunajského typu.

$\mathrm{Z}$ tohto pohladu príloha mäsitej potravy nie je sama o sebe ukazovatel'om vyššieho spoločenského postavenia. Súvisí s pohrebným zvykom aplikovaným pozostalými niektorých rodinných zväzkov v obmedzenom chronologickom rámci, nie kontinuálne počas používania nekropoly.

Typ 27 - Vajcia

(obr. 8: 27)

V dvoch hroboch (14 a 43; tab. VIII: 14; XVII: 43) zo VI. pohrebiskovej skupiny sa zaznamenal výskyt vaječných škrupín (obr. 12: f). Pohrebisko sa tak pripojilo $\mathrm{k} 12$ iným nekropolám, na ktorých sa vajcia z hydiny našli v 22 hroboch (Hanuliak 2004b, 194, 195). Podla toho ukladanie vajec súvisí so sporadicky aplikovaným pohrebným zvykom. Jeho podstata uniká, kedže sa dosial' nepodarilo spresnit význam vajec pre pochovaných.

Zo známych prameňov možno vyčítat' viacero informácií, ktorým chýba logická previazanost’ signalizujúca jednotnejšiu významovú podstatu. Názorovú platformu, stotožňujúcu vajcia so symbolom znovuzrodenia života, s túžbou po regenerácii životných síl (Dostál 1982, 184; Petényi 1994, 76; Smetánka 2014, 117-120) dotvára ich prevyšujúca prítomnost’ v hroboch detí $(44,7 \%$ prípadov). Nezanedbatelný podiel vajec $\mathrm{v}$ hroboch dospelých mužov (33,3\%) a žien (22 \%), doplnený ich občasnou viacpočetnostou $\mathrm{v}$ hrobe, môže byt' zasa považovaný za doklad o sezónne obmedzenom druhu posmrtného jedla (Geisler 1984, 494; Hoch-
manová-Vávrová 1962, 232; Justová 1990, 62, 166). Vo zvýšenej miere to platí pre miesta $\mathrm{v}$ okolí chodidiel a hlavy, do ktorých boli ukladané takisto keramické a drevené nádoby.

Spomenuté okolnosti sa stotožňujú s nálezovou situáciou doloženou aj v dvoch hroboch zo zhodnocovanej lokality. V hrobe $14 \mathrm{~s}$ dospelou ženou stredného veku bolo vajce uložené napravo od hlavy a dopíňalo prílohu mäsitej potravy a nápojovú látku z vedra. Dospelému mužovi stredného veku z hrobu 43 vajce uložili ku koncovej stene hrobovej jamy z blízkosti zámerne rozbitej a d’alšej celej keramickej nádoby. Sprievodné nálezové okolnosti majú nanajvýš priemerné hodnoty $\mathrm{v}$ porovnaní s nadpriemernými parametrami z hrobu 14.

Zhodnocovaným vajciam možno podla toho s väčšou istotou pričlenit význam potravinovej prílohy, bez ohl'adu k rozsahu magického poslania pripisovaného pozostalými. Prítomnost’ oboch hrobov v VI. skupine spája umiestňovanie vajec do hrobov s pohrebným zvykom aplikovaným jediným rodinným zväzkom miestnej komunity. V označenom mikropriestore sa takisto koncentruje výskyt keramických nádob (7 prípadov), mäsitej prílohy (2 prípady) doplnený jedným vedrom. Väčšina z hrobov patrí do mladšieho vel'komoravského horizontu.

Typ 28 - Spona

(obr. 8: 28)

Z hrobu 5 umiestneného v III. skupine pochádza predmet označený B. Chropouským $(1977,135)$ ako pracka (obr. 12: g; tab. II: 5: 1). Toto funkčné využitie mohol ovplyvnit pohyblivý jazýček pripevnený ku kruhovému telu s hrúbkou 2,5 mm a celkovým priemerom $38 \mathrm{~mm}$. Opísaný tvar s gulovito zhrubnutými koncami ramien, zhotovený technikou liatia z bronzu, nie je na území včasnostredovekého Slovenska dosial' známy.

Reprezentanti príbuznej formy, pochádzajúci z hrobov avarského kaganátu, bývajú označovaní ako kruhové spony. Ich výskyt sa koncentruje v zadunajskej časti Karpatskej kotliny. Zo Slovenska k nim patrí exemplár nájdený v hrobe 74 zlučitelný so záverečnou fázou pochovávania na pohrebisku v Čataji (Hanuliak/Zábojník 1982, 501, tab. I: 17).

Predmetná súčast̉ odevu patrí k najčastejšie doloženým reprezentantom podkovovitých spôn so štvorhranným, resp. kosoštvorcovým prierezom, roztepanými a následne zvinutými koncami. Koróziou napadnutý železný jazýček sa obvykle nezachoval. V primárnej polohe sa spony nachádzali na hrudi alebo v panve dospelých jedincov oboch pohlaví i detí. Podla toho by sa dalo azda pripustit’ pretrvávanie antických tradícií v odievaní, ked’že ide o predmety z doby rímskej, ktoré sa počas 
včasnostredovekého obdobia na sledovanom území nevyrábali (Tobias 2007, 333-335).

Zaujímavý moment vnáša do tejto problematiky podkovovitá spona nájdená v hrobe 48 na pohrebisku v Prušánkach. Jej oblúk s priemerom $53 \mathrm{~mm}$ je však vyhotovený zo železa. Spomenutý detail spolu s umiestnením predmetu v lavej časti panvy naznačuje, že táto masívnejšia spona mohla tvorit’ súčast' opaska noseného dospelým mužom stredného veku (Klanica 2006a, 76; tab. 28: 5; 2006b, 75). Identické použitie môžu naznačovat’ aj zástupcovia tohto druhu nájdení v sídliskových kontextoch mikulčického hradiska (Klanica 1986, 119, 120).

Odlišný funkčný kontext sa zaznamenal v hromadnom depote železných predmetov pripísanom putujúcemu kováčovi. Táto zaujímavá kolekcia nálezov bola v 6. stor. počas kritického momentu zakopaná do zeme v katastri dnešnej dolnorakúskej obce Wegscheid am Kamp. Súčastou depotu je okrem mince rímskeho cisára Galeria Maximiana z roku 311 aj podkovovitá spona. Podobné exempláre boli v Germánii i na iných územiach rímskych provincií hojne nosené v 2.-4. stor. n. 1. Z rozboru nálezov vyplynulo, že minca i bronzová spona reprezentujú v objavenom depote antikvárne kusy (Lauermann/ Scheinblechner 2017, 88-93), ktorým ich vlastník akiste pripisoval magické schopnosti s možným ochranným účinkom (Hanuliak 2004c, 31, 32).

Identický význam mohla mat' aj spona z dolnokrškanského hrobu 5. O takejto možnosti presviedča jej poloha v blízkosti zhlukovej pozície britvy, šidla a dvoch úštepov. Jej poloha konča chodidiel pochovaného navyše dokazuje, že nemohla slúžit’ ako súčast’ odevu. S väčšou pravdepodobnost'ou išlo a jednu z podôb antikvárneho amuletu. Vylúčit však nemožno ani využitie exemplára na zopnutie vrecka s drobnými predmetmi. To však neobjasňuje dôvod, pre ktorý predpokladané závesné vrecko z organického materiálu neležalo v oblasti panvy pochovaného, ale v druhotnej pozícii, kam ho priložili pozostalí.

Zo zretel’a nemožno vypustit', že sa analyzovaná spona svojim tvarom nestotožňuje s dosial' pertraktovaným podkovovitým variantom kruhových spôn. Ide o hybridný typ blízky omegovitým sponám (Tobias 2007, obr. 4: 8), ktorého oblúk nie je na koncoch ohnutý do spätných slučiek, ale zhrubnuté konce $\mathrm{k}$ sebe priliehajú. Z pohl'adu mapovania pôvodu oboch variantov kruhových spôn je podstatné, že ide o súčasti odevu nosené tradičným spôsobom v autochtónnom prostredí počas doby rímskej, ktoré boli následne využívané aj odlišným spôsobom. Ich výskyt doložený na území pruských kmeňov, vo vikingskom prostredí, takisto na území dnešného Pol'ska v 10.-15. stor. nemá s analyzovanými exemplármi genetický či kultúrny kontext (Jończyk
2013, 45-51; Mugurévičs 1977, 37, 84; Oxenstierna $1966,217,218)$.

\section{Typ 29 - Hrkálka}

(obr. 8: 29)

Jediný zástupca „samozvučných hudobných nástrojov“" pochádza z hrobu 8 (tab. IV: 8: 2) vyhĺbeného v IV. pohrebiskovej skupine (obr. 12: g). Ide o hrkálku, ktorá ležala pôvodne pri pravom predkolení detského jedinca stredného veku. Predmet je odliaty z bronzu. Spodná čast’ nezdobeného gul'ovitého tela je rozdelená dvomi priečnymi štrbinovými otvormi.

Estetickejšie pôsobí hrkálka nájdená $\mathrm{v}$ panve detského jedinca pochovaného v hrobe 84 z Pobedima-Na laze. Zhotovili ju takisto technikou liatia z bronzu. Povrch zdobia vodorovné sústredné ryhy nahradené v dolnej časti trojuholníkovitými kompozíciami (Vendtová 1969, 187, obr. 57: 8). Ak sa k takýmto prípadom na ilustráciu pripojí aj hrkálka z hrobu 718 v Čakajovciach (Rejholcová 1995b, 79, tab. CXII: 13), z hrobu 113 kostolného cintorína (Kalousek 1971, 79), z hrobu 124 na južnom predhradí Břeclavi-Pohanska (Přichystalová 2007, 177, obr. 6) a z hrobu 117 z Uherského Hradištła-Horných Kotvic (Marešová 1983, 50, tab. 12: 12) zviditel’ní sa prepojenie takýchto predmetov s detskými jedincami. Ich dlhodobo opotrebovávaný povrch s neraz poškodeným závesným uškom zasa poukazuje na ich zhotovovanie v období avarského kaganátu. $\mathrm{V}$ tomto prostredí sa sformovalo aj ich účelové využitie pri zdobení konských postrojov doplnené o ochrannú schopnost' voči všeobecne vnímaným škodlivým silám (Dostál 1966, 59; Zábojník 2009, 56). Rozhodujúcu úlohu pritom zohrával zvuk vznikajúci pri samovolnom pohybe, ktorý pri akomkolvek zafarbení eliminoval negatívne sily sídliace v tichej neistote (Frolíková-Kaliszová 2000, 245; Galuška 1996, 56; Hanuliak 1994, 47).

Pertraktovaná apotropajná účinnost' sa preniesla aj do vel'komoravského obdobia a markantnejšie prejavila u jedincov z najzranitel'nejšej skupiny vtedajšej society (Hochmanová-Vávrová 1962, 235; Smetánka 2003, 14). V rovnakom duchu vnímaný inštrument $\mathrm{z}$ dolnokrškanského hrobu 8 nie je, vzhl'adom na spomenuté okolnosti, sám o sebe chronologicky citlivý. Jeho spoločný výskyt s úzkou sekerou pripúšta posunutie pochovanie zomrelého, s vyšším spoločenským postavením, do staršieho vel'komoravského horizontu.

\section{Typ 30 - Sekerovitá hriona}

(obr. 8: 30)

Z hrobu 49 (tab. XX: 49: 4), vyhíbeného v V. pohrebiskovej skupine (obr. 12: g), pochádza zlomok sekerovitej hrivny dlhý $63 \mathrm{~mm}$. Tento artefakt s tromi inými predmetmi ležal na vnútornej strane pravého 
kolena dospelého muža stredného veku. K nálezom patriaci nôž, ociel'ka a úštep mohli v súlade so zhlukovou polohou tvorit obsah závesného vrecka. Podla toho nemohla byt' ani sekerovitá hrivna pre tohto jedinca bezcenná. Jej skutočný význam sotva dnes objasníme. Zlomkovitostou limitované praktické využitie mohli pozitívne rozšírit magické schopnosti úspešné proti obávaným nečistým silám, ktoré sa v minulosti pripisovali železným predmetom (Eisner 1966, 434, 435; Horváthová 1995, 21).

Naznačený problematický moment nepomáhajú doriešit d’alšie podobné prípady z obmedzeného počtu iných pohrebiskových lokalít, ktorými sa skôr rozširujú interpretačné možnosti. Na ilustráciu sa dajú uviest' dva hroby z cintorína pri 6. mikulčickom kostole. V hrobe 1477 s dospelou ženou uloženou v pokrčenej polohe na pravom boku ležal vyhodnocovaný artefakt za hlavou. U dospelého muža z hrobu 1495 sa neúplná hrivna našla spolu s ociel'kou v lavej časti panvy (Profantová 2003, 74, 86, tab. 74: 1; 76: 1). Podobné nálezové okolnosti sa zrejme zdokumentovali aj v hrobe $73 \mathrm{v}$ Uherskom Hradišti-Horných Kotviciach (Marešová 1983, 125).

Avšak v hrobe 199/AZ a 330/AZ zo Starého Města-Na valách pochádzajú tangovaní zástupcovia zo zásypu hrobovej jamy (Hrubý 1955, 387, 400, tab. 77: 10, 11). Analogickým prípadom sú dve hrivny pochádzajúce zo zásypu hrobu 5 v Kopčanoch-Hrúdoch I (Kraskovská 1969, 65, obr. 9: 10, 11). Identické prípady sa vyskytujú na lokalitách s hrobmi zahlbovanými do starších sídliskových kontextov. Je isté, že sa v uvedených prípadoch vytráca užší vztah hrivien $\mathrm{k}$ pochovaným. Súčasne s tým neprichádza do úvahy akýkolvek spôsob ich praktického využívania vrátane ich magického poslania.

Ešte menej pravdepodobné sa ukazuje vyzdvihovanie ekonomickej hodnoty predmetných hrivien a ich spájanie s predmincovnými platidlami (porovnaj: Pošváŕ 1963, 10). Výnimkou môže byt’ azda hrob 1/47 zo Žlkoviec s tromi zachovanými hrivnami umiestnenými konča chodidiel pochovaného (Budinský-Krička 1947, 35-38).

Zlomok sekerovitej hrivny z dolnokrškanského hrobu 49 patrí z primárneho pohladu k l’ahším variantom malých exemplárov II. typu s korýtkovito rozkutým ukončením a závesným otvorom prerazeným priebojníkom (Pleiner 1961, 426). Vzhl'adom na všeobecné rozšírenie vo vel'komoravskom období nemôžu byt títo zástupcovia chronologicky citliví. Neistá je takisto schopnost' tohto fragmentu indikovat úroveň postavenia jedinca $\mathrm{v}$ danej komunite. K pozitívnym momentom azda patrí, že sa vd’aka dokumentačným podkladom mohol preukázat’ priamy vztah artefaktu k pochovanému. Nie ako to bolo prezentované v minulosti D. Bialekovou (1990, 106, 111).

\section{INTERPRETÁCIA POZNATKOV}

Úvahy ohladne spracúvania nálezového fondu z pohrebiska v Nitre-Dolných Krškanoch pozitívne ovplyvnila prierezová charakteristika lokality načrtnutá B. Chropovským (1977, 134-136, obr. 58). Vd’aka nej i kresbám účelového výberu nálezov sa mali počiatky pochovávania posunút $\mathrm{k}$ začiatkom 9 . stor. Tento moment predstavuje významný medzník k priblíženiu najstaršej etapy vel'komoravských pohrebísk na území Slovenska. Dôležitú úlohu taktiež zohrala dominantná pozícia náleziska v rámci tamojšej sídelnej enklávy. Jej jadro sa sformovalo na prístupovej trase smerujúcej do historickej Nitravy z južného smeru.

Okrem osamoteného hrobu a dvoch hrobov vyhíbených v sídliskovom areáli (Kuzma 2001, 103, 104; Ruttkay, M. 2004, 153; 2005, 59) figurujú v danom priestore aj dve malé pohrebiská (Hanuliak 1989, 211; Chropovský 1986a; 1986b). V piatich hroboch z polohy Dvor OSP sa našiel brús, nôž, korálik, sekera a ostroha s upínacím remienkom. V polohe Sklady OD Prior sa odkrylo šest' hrobov. Význam náušnice neznámeho typu, spony, nožov a úštepov adekvátne zvyšujú britva, vedro, sekera, hrot kopije a dvojostrý meč (Hanuliak 2004b, tab. LIX: 14; LX: 1, 2, 4, 12). Ak bol v oboch prípadoch pohrebiskový areál kompletne odkrytý, mohli obe nekropoly patrił k nevel'kým sídliskám používaným krátkodobo počas staršieho vel'komoravského horizontu. Ich obyvatelia s vyšším sociálnym statusom patrili akiste $\mathrm{k}$ vojenskej družine sídliacej v zázemí hradského mesta chrániacej súčasne dôležitú prístupovú trasu (Galuška 2017, 167, 179).

Klúčovú úlohu malo $\mathrm{v}$ tomto mikroregióne zohrávat' spracúvané pohrebisko. Presviedča o tom značný počet hrobov s predpokladaným kontinuálnym pochovávaním počas 9. stor. Prvotné očakávania zreálnili výsledky analýz nálezového fondu. V nich sa postupne vyskytli negatívne i špecifické momenty odlišné od tradičných prejavov zaznamenávaných vo vidieckom prostredí. Ich význam napriek tomu nenadobudol taký rozsah, ktorý by skomplikoval vypracovanie rámcovej charakteristiky pohrebiska, načrtnutie predstavy o pochovávajúcej komunite.

\section{Chronologické vzt’ahy}

Pri nekropolách s väčším počtom hrobov nadobúda prvoradý význam vymedzenie časového rámca ich používania doplneného prípadným potvrdením ich kontinuálneho vývoja. Pri zbežnom pohlade poskytuje spracúvané pohrebisko nálezový fond, ktorý by mal prispiet $\mathrm{k}$ naplneniu očakávaných cielov. K východiskovému základu patrí 38 hrobov (73,3 \% prípadov) s rôznymi typmi predmetov. 
Údaj je blízky k hodnote 75 \% vyčíslenej v Nitre-Lupke, 75,4 \% v Čakajovciach, súčasne prevyšuje údaj 53,8 \% z Vel'kého Grobu. Na dolnokrškanskom pohrebisku sa takisto vyskytol vcelku nízky podiel zástupcov $\mathrm{s}$ osamotenými predmetmi $\mathrm{v}$ jednom hrobe (39,4 \% prípadov), zatial čo v Nitre-Lupke nachádzame $42 \%$ takýchto prípadov, vo Svätom Petre 50 \%, vo Vel'kom Grobe ide o 57,9 \%.

Za prvý negatívny moment treba zasa označit vysoký podiel chronologicky málo citlivých a k datovaniu nevhodných predmetov s dominujúcim zastúpením železných nožov zaznamenaných v $50 \%$ prípadov, zatial' čo v Nitre-Lupke ide o $29 \%$, vo Svätom Petre o 37,5 \%. Podla toho železné nože predstavujú napohlad nosnú súčast' pohrebného inventára, ktorou sa znižuje požadovaná kvalita potrebná k chronologickej špecifikácii hrobov. Vzhladom na prepracované datovacie kritériá keramických nádob, spätých $\mathrm{v}$ prevahe s mladším vel'komoravským horizontom, nenadobudol zásadnejší význam ich zvýšený výskyt vyčíslený na 39,4% prípadov.

Chýbajúce opakovane doložené kombinácie náušníc veligradského typu (typ 6-9) možno označit za d’alší negatívny moment. Ich osamotené exempláre z drahých a vzácnych kovov sa v štyroch hroboch vyskytli bez vzájomnej kombinácie. Navyše, náušnica sjedným vencom granúl $v$ závesku sa v hrobe vyskytla bez dalších príloh (tab. XI: 19: 1). Dva exempláre z hrobu $18 \mathrm{~s}$ dvomi vencami granúl v závesku doplña nôž s vedierkom (tab. X: 18: 1-4), ktoré by sa podla tvaru závesných kovaní mohlo zlúčit so starším velkomoravským horizontom. Náušnicu s tromi vencami granúl v závesku, spolu so zlomkom d’alšej, dopíňal v hrobe 16 náhrdelník s málo chronologicky citlivými korálikmi vel'komoravského typu doplnenými splošteným gulovitým reprezentantom včasnohistorickej proveniencie (tab. VIII: 16: 1-3). Podla opísaných nálezových okolností nevytvárajú náušnice $\mathrm{z}$ danej skupiny reprezentatívne kombinácie umožňujúce ich precíznejšiu chronologickú špecifikáciu.

Za doklad o používaní takýchto šperkov zdobiacich hlavu v rovnakom časovom rámci by sa mohol prijat' sústredený výskyt príslušných hrobov v II. pohrebiskovej skupine zo západnej časti pohrebiska (obr. 7). Špecifický moment predstavuje umiestnenie príslušných hrobov v líniovej zostave, ktorú okrem hrobu 17 so skleným gombíkom (tab. X: 17: 1) dopĺña hrob 6. Z jeho výplne pochádza nôž s osobitým významom a vedierkom so starším typom závesných kovaní (tab. III: 6: 1, 2).

Bronzové náušnice podunajského typu (typ 1-5) sa zasa sústredujú v rámci VI., okrajovo aj v susediacej V. a VII. skupine z východnej časti pohrebiska (obr. 7: a-c). Ich spoločný výskyt sa zaznamenal pri type 1 a 2 (hrob 27), pri type 3 a 5 (hrob 47). Z hrobu 33 pochádza ich vzácna kombinácia s bronzovým exemplárom veligradského typu s dvojkónickým záveskom (typ 9; tab. XV: 33: 1-3).

V limitovanom priestore zaznamenanú prítomnost predmetných náušníc možno opät vnímat’ ako svedectvo o ich jednotnom časovom zaradení. K jeho vymedzeniu nie sú vhodné tri hroby bez pohrebného inventára ani d’alší reprezentanti v podobe hlinených praslenov, mäsitej prílohy a keramických nádob zo skupín A a B. Signifikantnejšie sú vyspelé keramické nádoby zo skupiny C uložené takisto v V.-VII. skupine (obr. 12: c), ktoré posúvajú hroby z východnej časti pohrebiska do mladšieho vel'komoravského horizontu. Uvedená chronologická špecifikácia vcelku korešponduje s dlhodobejším používaním šperkov menej nápaditého tvaru počas celého vel’komoravského obdobia vrátane tohto úseku. A navyše, tak ich zástupcovia, ako aj iné typy šperkov, mohli byt๋ uložené do hrobov s istým časovým odstupom od momentu ich zhotovenia. V náznakoch na to poukazujú poškodené exempláre, ktoré sa napriek tomu nad’alej používali (Galuška 1996, 199; 2013, 244, 245; Chorvátová 2007, 84). Dost’ presvedčivo to potvrdzujú náušnice špecifického typu z hrobov 14 a 34 (tab. VII: 14: 1, 2; XIV: 34: 2). $\mathrm{V}$ tomto časovom rámci sa zdá byṫ menej obvyklý gombík so zvislo rebrovaným povrchom z pozláteného bronzového plechu (tab. VI: 13: 1). Pochybnosti pomáha odstránit identický tvar gombíka nájdený na kostolnom cintoríne v areáli Devínskeho hradu, používaný počas mladšieho vel'komoravského horizontu (Plachá/Hlavicová/Keller 1990, 109, 110, tab. 37).

V predchádzajúcej časti boli uvedené základné zložky, ktoré prispeli k vymedzeniu oboch najvýznamnejších skupín hrobov zo západnej a východnej časti pohrebiska spätých so starším i mladším velkomoravským horizontom. Výstižnejšie vymedzenie oboch časových úsekov v rámci 9. stor. nie je možné z nedostatku kvalitných opôr. Existenciu tohto modelu napriek tomu podporujú zmeny v pohrebných zvykoch zmapované po zohladnení rozdielneho počtu hrobov v oboch častiach. V západnej z nich napríklad dominujú hrobové jamy s nadpriemerným objemom, pravé predlaktia horných končatín uložené v panve a priložené britvy i vedrá. Vo východných sektoroch majú zasa prevahu lavé predlaktia i obe predlaktia $\mathrm{v}$ panve, keramické nádoby, mäsité prílohy i vajcia. Vnútorná úprava hrobov sa vyskytuje proporcionálne $\mathrm{v}$ oboch priestoroch. Naproti tomu sa počet hrobov bez pohrebného inventára voči pôvodnej hodnote $12,5 \%$ zvýšil vo východnej časti na $24,3 \%$ prípadov (obr. $4 ; 13$ ).

Zo zástupcov s porovnatelným počtom hrobov a identickou dĺžkou ich používania v 9. stor. je k analyzovanému pohrebisku najviac blízka nekropola zo Svätého Petra (Béreš 1995). Okrem príbuzných kriviek mapujúcich frekvenciu zložiek pohrebného rítu je taktiež vel'mi blízka početnost̉ i skladba 


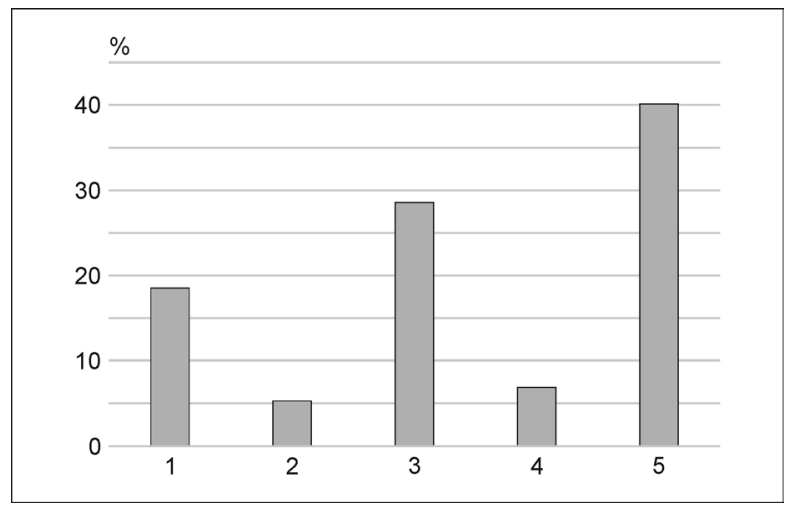

Obr. 14. Svätý Peter. Výskyt hlavných typov predmetov a ich variantov v materiálových skupinách. 1 - šperky; 2 - súčasti odevu; 3 - predmety dennej potreby; 4 -zbrane; 5 - predmety kultového charakteru.

nájdených predmetov. Okrem kopije k nim patria britvy, opaskové pracky, prasleny amulety i gombíky. Hroty šípov, prstene a nákrčník, kamennébrúsy, hroty šípov v Dolných Krškanoch síce chýbajú, avšak náušnice, koráliky, sekery a vedrá sú vo Svätom Petre iba o málo početnejšie. Napriek spomenutým hodnotám je výsledný pomer tradičných materiálových skupín mierne pozmenený voči ich frekvencii na pohrebisku v Dolných Krškanoch. Pričinil sa o to najmä neúmerne vysoký počet keramických nádob. Ich reprezentanti v počte 55 exemplárov boli uložení do 40 hrobov (obr. 14). Ide nesporne o takú hodnotu, ktorá sa nezaznamenala ani na pohrebisku výrobcov keramického riadu z Nitry-Lupky (Chropovský 1962, 202, 203). K porovnaniu vel'mi blízkej skladby nálezového fondu z oboch lokalít treba uviest' $\mathrm{v}$ zásade odlišnú štruktúru materiálových skupín zaznamenanú na pohrebisku z 10.-11. stor. v Nitre-Horných Krškanoch (obr. 15). Jej podoba približuje štruktúru materiálových skupín vyskytujúcich sa na pohrebiskách z povel'komoravského a začiatkov vrcholnostredovekého obdobia.

V Dolných Krškanoch zaznamenaný postup pochovávania napredujúci z vyššie položenej do zníženej časti terénu poznáme aj z pohrebiska v Čakajovciach, Nitry pod Zoborom, Trnovca nad Váhom-Horného Jatova či Vel'kého Grobu. V Dolných Krškanoch môže tento úzus spochybňovat podpriemerné zahustenie hrobov v I.-IV. pohrebiskovej skupine, ktoré býva $\mathrm{v}$ niektorých prípadoch považované za neukončený cyklus pochovávania. Na margo tejto okolnosti treba uviest príbuzný postup inhumácie zrekonštruovaný vo Vel'kom Grobe. Tamojší pohrebiskový areál pozostával z dvoch častí. V jeho vrcholnom úseku sa riedko vyhĺbené hroby zo staršieho vel'komoravského úseku zhlukovali zhruba $\mathrm{v}$ troch až štyroch rozptýlených skupinách. Hroby z mladšieho horizontu s koncentrovaným pochovávaním ležia $\mathrm{v}$ mierne zníženom svahovitom teréne (Chropovský 1957, 191).

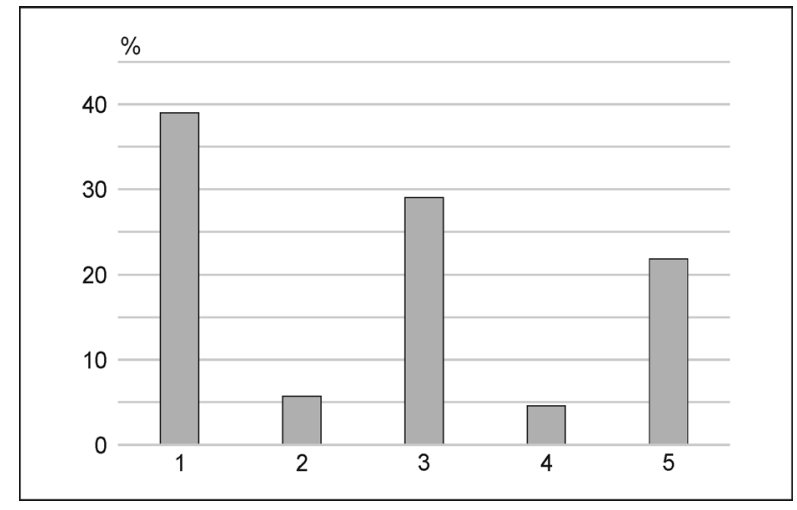

Obr. 15. Nitra-Horné Krškany. Výskyt hlavných typov predmetov a ich variantov v materiálových skupinách. 1 -šperky; 2 - súčasti odevu; 3 - predmety dennej potreby; 4 - zbrane; 5 - predmety kultového charakteru.

Spracúvaná nekropola má sofistikovanejšiu priestorovú štruktúru. Pôvodne pozostávala $\mathrm{z}$ troch líniových pásov zaplnených niekol'kými skupinami hrobov. Do horného pásu zo staršej etapy pochovávania patrí I. a II. skupina. Dolný pás z mladšieho horizontu je zložený z V.-VIII. skupiny. Ťažiskovú čast’ zo stredného úseku, ležiaceho medzi nimi nepoznáme. Okrem III. a IV. skupiny mali do tohto pásma patrit zhruba dalšie dve skupiny hrobov. Chýbajúci bádatel'ský záujem o doskúmanie tangovanej časti po odstránení navŕšenej depónie zeminy vytvoril negatívny precedens. Následkom toho sa nedá s potrebnou presvedčivostou potvrdit’ ani očakávaný kontinuálny priebeh pochovávania, zamedzilo sa získanie dôležitých opôr pre spresnenie datovania, vytvorenie komplexnejšieho obrazu o pochovávajúcej komunite.

Pre obmedzenú datovaciu schopnost' pohrebiskového materiálu a chýbajúce ustálené kombinácie nálezov sa väčšinová čast̉ reprezentantov nedá, žial', chronologicky špecifikovat'. Nálezový fond poskytuje príležitost̉ $\mathrm{k}$ rámcovému začleneniu príslušných pohrebiskových skupín do staršieho a mladšieho vel'komoravského horizontu bez možnosti spresnenia počiatočného a záverečného medzníka. V nálezovom fonde však chýbajú zložky, ktoré by záverečnú etapu pochovávania posunuli do 10. stor. K opatrnému formulovaniu niektorých postrehov nabáda nedostatočný plošný odkryv. Aj preto nepoznáme okrajové línie pohrebiska nevyhnutné k stanoveniu jeho skutočného rozsahu.

\section{Sociálne vzt’ahy}

Z mnohostranného modelu sociálnych vztahov nadobúda prvoradý význam prirodzený biologicko-fyzický základ členiaci jedincov podla pohlavia a veku uložených v prebádaných hroboch. Základ- 
né údaje o nich sa čerpali z výsledkov odborných analýz antropologického materiálu vypracovaných M. Vondrákovou z Katedry antropológie PF UKF.

Pomocou nich sa spresnila štruktúra predpokladaných rodinných zväzkov v oboch oddelených úsekoch nekropoly s rozdielnym počtom hrobov. $\mathrm{Z}$ porovnania údajov, odvodených z proporcionálneho zastúpenia jedincov, nie sú medzi obomi segmentmi výraznejšie rozdiely. Zanedbatelný rozdiel u detských jedincov dokazujú hodnoty 37,2 \% a 39,5\%. Dospelí muži sú voči ženám v západných pohrebiskových skupinách o málo početnejší ako vo východných, kde dospelé ženy prevyšovali mužov (obr. 16). V tomto priestore boli nezvyčajne pochovaní aj dvaja detskí jedinci najmladšieho veku (inf. I), dvaja muži (M, sen.) azda aj žena stareckého veku (F? sen.). Bez výsledkov odborných analýz by nebolo správne vynášat' predčasné úvahy prisudzujúce kvalitnejšie životné pomery príslušníkom z tej-ktorej skupiny miestnych obyvatelov.

K ovel'a náročnejším úlohám patria snahy o zmysluplnejšiu interpretáciu rozdielov zaznamenaných v pohrebiskovom fonde prostredníctvom zhmotnenej podoby citlivejších zložiek pohrebného rítu a skladby pohrebného inventára. Primárnym prameňom z oboch skupín chýba ustálená kvalita, ktorá by potvrdila ich previazanost' $s$ istým hodnotovým systémom. Nemalo by íst' o prekvapivé zistenie, ked’že spracúvaná nekropola patrí k dedinským komunitám. Rodinné zväzky týchto pospolitostí nedisponovali pestrejšie štruktúrovanými vztahmi ani majetkovými pomermi. Napriek tomu pozostalí pristupovali k posmrtnému zaopatrovaniu jedincov diferencovane. Spôsob ich myslenia nepoznáme, a preto sotva priblížime mieru $\mathrm{v}$ akej boli pritom zohladňované vtedajšie zásady predkrestanského pohrebného rítu, ekonomické, príbuzenské väzby či emotívne pohnútky. Opakovaný výskyt niektorých prejavov $\mathrm{v}$ istých pohrebiskových skupinách pripúšta vyššiu mieru individuálneho prístupu. Na ilustráciu možno uviest’ častejší výskyt hrobových jám $\mathrm{s}$ nadpriemerným objemom, uloženie pravých predlaktí v panve, pochovanie detských jedincov s náušnicami veligradského typu a vedier v II. skupine hrobov. V VI. skupine sa zasa kumuluje prítomnost' dvoch typov náušníc podunajského typu, náušníc špecifického typu, mäsitej prílohy a zástupcov keramických nádob všetkých troch typov (obr. $4 ; 12 ; 13$ ).

Odlišnú mieru individuálneho prístupu evidujeme v činnostiach prevyšujúcich mieru štandardných parametrov. Okrem emotívnych pohnútok a citových väzieb sa mohlo na výslednom efekte podielat prihliadanie k významnejšiemu postaveniu jedinca $v$ rodinnom zväzku, $k$ jeho zásluhovosti nadobudnutej aktivitami v pozemskom živote. Ide

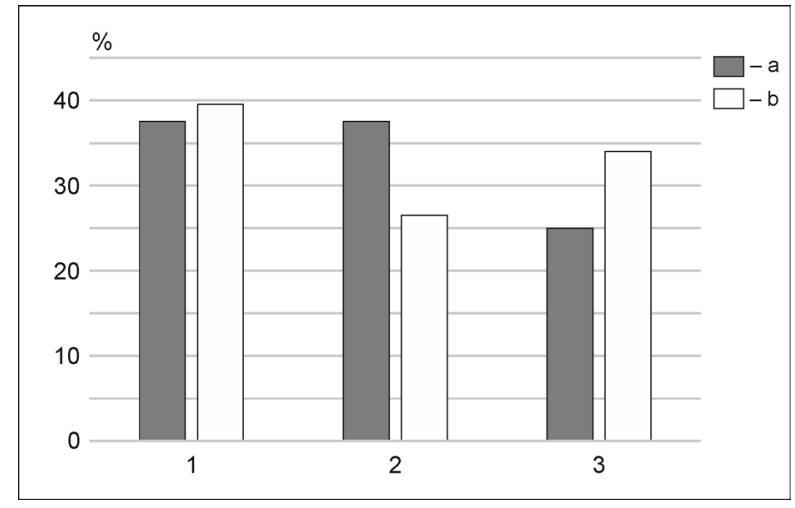

Obr. 16. Nitra-Dolné Krškany. Výskyt jedincov rozdielneho pohlavia a veku v častiach pohrebiska. 1 - detskí jedinci; 2 - dospelí muži; 3 - dospelé ženy; a - západná čast'; b - východná čast'.

o archeologicky nepreukázatelné skutočnosti, bez ktorých však nenájdeme klúč k osvetleniu nadštandardných prejavov zabezpečovaných zvýšenými hodnotami nálezového fondu a pracovného výkonu odvedeného pri úprave hrobovej jamy.

K prijatelnej akceptácii naznačenej možnosti poslúži niekol'ko príkladov. Do sledovanej kategórie s určitostou patrí 3-5-mesačné diet’a z hrobu 13 pochované $\mathrm{v}$ hrobovej jame $\mathrm{s}$ nadštandardnými rozmermi (híbka $170 \mathrm{~cm}$, objem 3,1 m³), s gombíkom so zvislo rebrovaným povrchom z pozláteného bronzového plechu a na lokalite jediným prípadom spoločného výskytu vedra s keramickou nádobou (tab. VI: 13: 1; VII: 13: 3, 4).

S menej presvedčivým svedectvom sa stretávame v hroboch 16, 18 a 19, v ktorých boli v nadrozmerných jamách opät uložení detskí jedinci s náušnicami veligradského typu z drahých a vzácnych kovov doplnených náhrdelníkom a vedrom (tab. VIII: 16: 1-3; X: 18: 1, 2, 4; XI: 19: 1). Prezentovanú skupinu taktiež dopĺńa hrob $8 \mathrm{~s}$ dieţatom, ktorému bola k pravému predkoleniu priložená sekera. Vzhl’adom na vek 3-4 rokov sotva mohol jedinec túto zbraň aktívne používat. Prijatelnejšie vyznieva názor označujúci predmet za symbol mocenskej pozície prenesenej prostredníctvom zdedeného sociálneho statusu z dospelej osoby na potomka.

Významnejší post $\mathrm{v}$ tamojšej komunite zastával dospelý muž stredného veku pochovaný v hrobe 4. Patričnú dôležitost' nadobudne kvalitne zhotovený hrot kopije uloženej medzi pravým plecom a hlavou. K lavému kolenu bolo priložené závesné vrecko s predmetmi osobnej potreby, z ktorých vyniká najmä britva (tab. I: 4: 3, 4; II: 4: 1, 2, 5, 6). Skompletizovaná kolekcia nálezov dovoluje označit pochovaného za pešieho bojovníka a zaradit ho do vyššej vrstvy vel'komoravskej spoločnosti. Správnosṫ zaradenia podporuje nielen nadrozmerná hrobová jama (híbka 
$151 \mathrm{~cm}$, objem $2 \mathrm{~m}^{3}$ ), ale aj z väčšej časti zachovaná drevená podložka nájdená pod telesnými zvyškami.

Podla nadrozmerných parametrov hrobovej jamy (híbka $200 \mathrm{~cm}$, objem 3,5 m³) by sa mohol významnejší post pripísat takisto dospelému mužovi z hrobu 6. Drevená úprava hrobovej jamy síce chýba, dôležitejšia je prítomnost' vedra. Klúčový význam nadobudol nôž umiestnený na neprehliadnutel'nom mieste v strede hrudníka. Jeho tvar je totiž odlišný od nožov bežne používaných vo vel'komoravskom prostredí. O výnimočnost' sa pričinila predížená rukovät pokrytá zdobenými platničkami zhotovenými z parohoviny (tab. III: 6: 1, 2). S prípustnou dávkou tolerancie môže íst' o predmet symbolizujúci navonok významnejšiu pozíciu tohto muža v dolnokrškanskej komunite.

Jediným náprotivkom muža z predchádzajúceho hrobu $\mathrm{v}$ ženskej časti populácie by mohla byt dospelá žena stredného veku z hrobu 14. Názor sa opiera o dve strieborné náušnice špecifického typu, dvojicu nožov, mäsitú prílohu a vedro, ktoré dopíňajú nadpriemerné híbkové parametre s hodnotou $200 \mathrm{~cm}$. Jej objem vyčíslený na $5,4 \mathrm{~m}^{3}$ predstavuje na pohrebisku najvyššiu hodnotu svojho druhu.

Zomrelí z predchádzajúcich siedmich hrobov patria podla objektívne stanovených kritérií $\mathrm{k}$ zástupcom $\mathrm{s}$ vyšším postavením $\mathrm{v}$ rodinných zväzkoch. Vo zvyšných šiestich hroboch s nadpriemernými rozmermi hrobových jám chýbajú hodnotnejšie predmety pohrebného inventára. Nemožno nevidiet,', že sa do tejto skupiny nezaradili hroby 44 , 48 a 51, s uloženým dospelým mužom, ženou a dietatom, v ktorých sa zachovali zvyšky po drevenej úprave hrobovej jamy. K nedoriešeným problémom patrí dôvod, pre ktorý sa v celej kolekcii hrobov s prejavmi vyššieho spoločenského postavenia ocitajú dospelí muži až na poslednom mieste. Táto skutočnost' sa dá vyčítat zo spriemerovaných híbkových a objemových údajov hrobových jám. Zatial čo u detských jedincov ide o hodnoty $155,5 \mathrm{~cm}$ a $3 \mathrm{~m}^{3}$, u dospelých žien $149 \mathrm{~cm}$ a 3,8 $\mathrm{m}^{3}$, relevantné údaje v hroboch dospelých mužov vystúpili iba na $126 \mathrm{~cm}$ a $2,6 \mathrm{~m}^{3}$. Situáciu naprávajú spriemerované hodnoty všetkých preskúmaných hrobov. Až v týchto globálnych hodnotách opät nadobúdajú tradičné prvenstvo dospelí muži, až na d’alších miestach sa ocitajú dospelé ženy a detskí jedinci.

Výsledná štruktúra sociálnych vztahov, vypracovaná na základe zhmotnených prejavov pohrebných zvykov i vystrojovania pochovaných pohrebným inventárom, je typická pre predkrestanský hodnotový systém. $V$ súlade s tým sa uplatňovali vtedajšie zásady pri výbere pohrebiskového areálu i jeho umiestnení v tamojšom prírodnom i pedologickom prostredí. Možné prieniky krestanskej vierouky do myslenia ludí sa v pohrebných zvykoch nezaznamenali.

\section{ZÁVER}

V predchádzajúcich kapitolách sú prezentované poznatky získané z vyhodnotenia 54 hrobov. Tie patria k nálezovému fondu získanému v roku 1976 v tažiskových priestoroch pohrebiska. Jeho stredná čast' s okrajovými úsekmi nebola z objektívnych príčin prebádaná. To sčasti obmedzuje prijatel'nost’ nadobudnutých poznatkov. V platnosti napriek tomu zostáva spôsob umiestňovania hrobov do ôsmich pohrebiskových skupín zaplnených s rôznou hustotou.

V zhmotnených zložkách pohrebného rítu figurujú takmer jednotné prejavy. Odchýlky od štandardného uloženia telesných zvyškov nemajú vyššiu intenzitu, chýba ich častejší výskyt. V plnom rozsahu to platí aj v prípade tvaru a rozmerov hrobových jám. Zvyšky drevených úprav rozdielnych typov sú ešte sporadickejšie. Výnimočné prípady preventívnych a posteriórnych obranných zákrokov na pochovaných sa vykonávali v súlade s vtedajšími predkrestanskými princípmi. Ich vplyv sa prejavil aj pri vytyčovaní orientácie zomrelých, pri umiestňovaní pohrebiska v tamojšom prírodnom prostredí.

Menej potešitelná je skladba pohrebného inventára zredukovaná na 30 hlavných typov a ich variantov. V zostave chýbajú najmä zástupcovia, ktorí bývajú na iných súvekých lokalitách sporadickejšie zastúpení. Prínos poskytnutých informácií znižuje výrazný podiel reprezentantov zo skupiny kultového charakteru a dennej potreby, pretože majú nízku až zanedbatel'nú datovaciu schopnost'. Kvalitnejšie informácie tohto druhu neposkytujú ani náušnice podunajského a veligradského typu. Ich exempláre sa nevyskytujú $\mathrm{v}$ ustálených kombináciách s inými predmetmi. Navyše, pochádzajú z hrobov umiestnených $\mathrm{v}$ dvoch úsekoch nekropoly oddelených nepreskúmanou častou. Pre nedostatočnú kvalitu dostupných údajov sa dá pochovávanie na pohrebisku iba rámcovo zaradit do prvej a druhej polovice 9. stor. Dížka používania pohrebiska sa nedá stanovit', pretože nie je známy jeho počiatočný ani záverečný úsek. S definitívnou platnostou nie je možné potvrdit ani $\mathrm{v}$ náznakoch zaznamenaný kontinuálny postup v pochovávaní smerujúci zo západnej do východnej časti nekropoly. Limitovaná kvalita vstupných údajov napriek tomu umožňuje vyčlenit nepočetnú skupinu jedincov s vyšším, resp. prestížnejším postavením v miestnej komunite.

Z celkového pohladu treba ocenit poskytnutú príležitost' $\mathrm{k}$ vyhodnoteniu dosial' nespracovaného nálezového fondu získaného z lokality patriacej vo vel'komoravskom období na Slovensku k vel'kým pohrebiskám. Aj vd’aka tomu sa podarilo načrtnút význam lokality v dolnokrškanskej sídelnej enkláve umiestnenej na južnom okraji jadra historickej Nitry. 


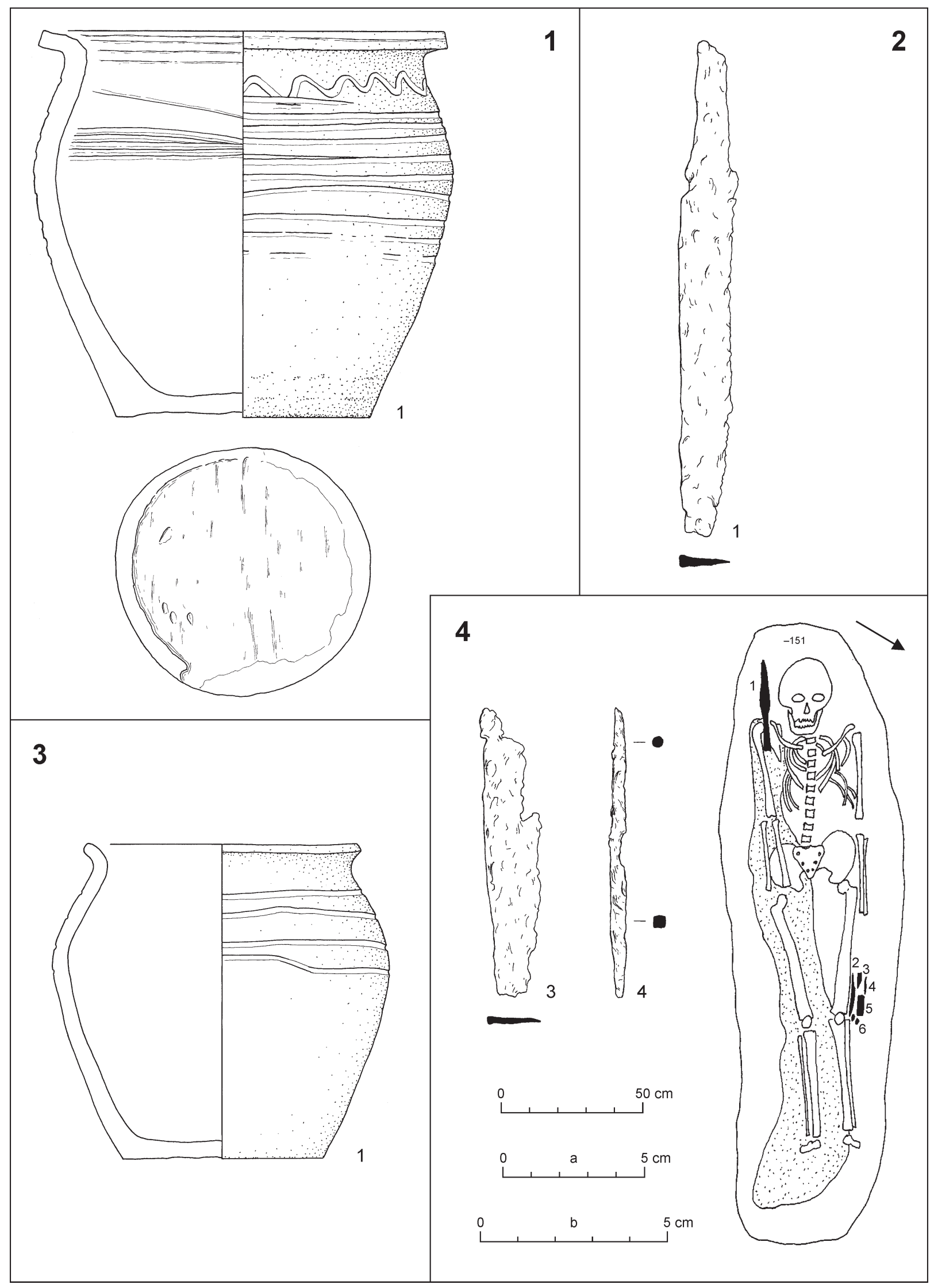

Tab. I. Hroby 1-4, plán a nálezy. Mierka: a - 1: 1, 3: 1; b - 2: 1, 4: 3, 4. 


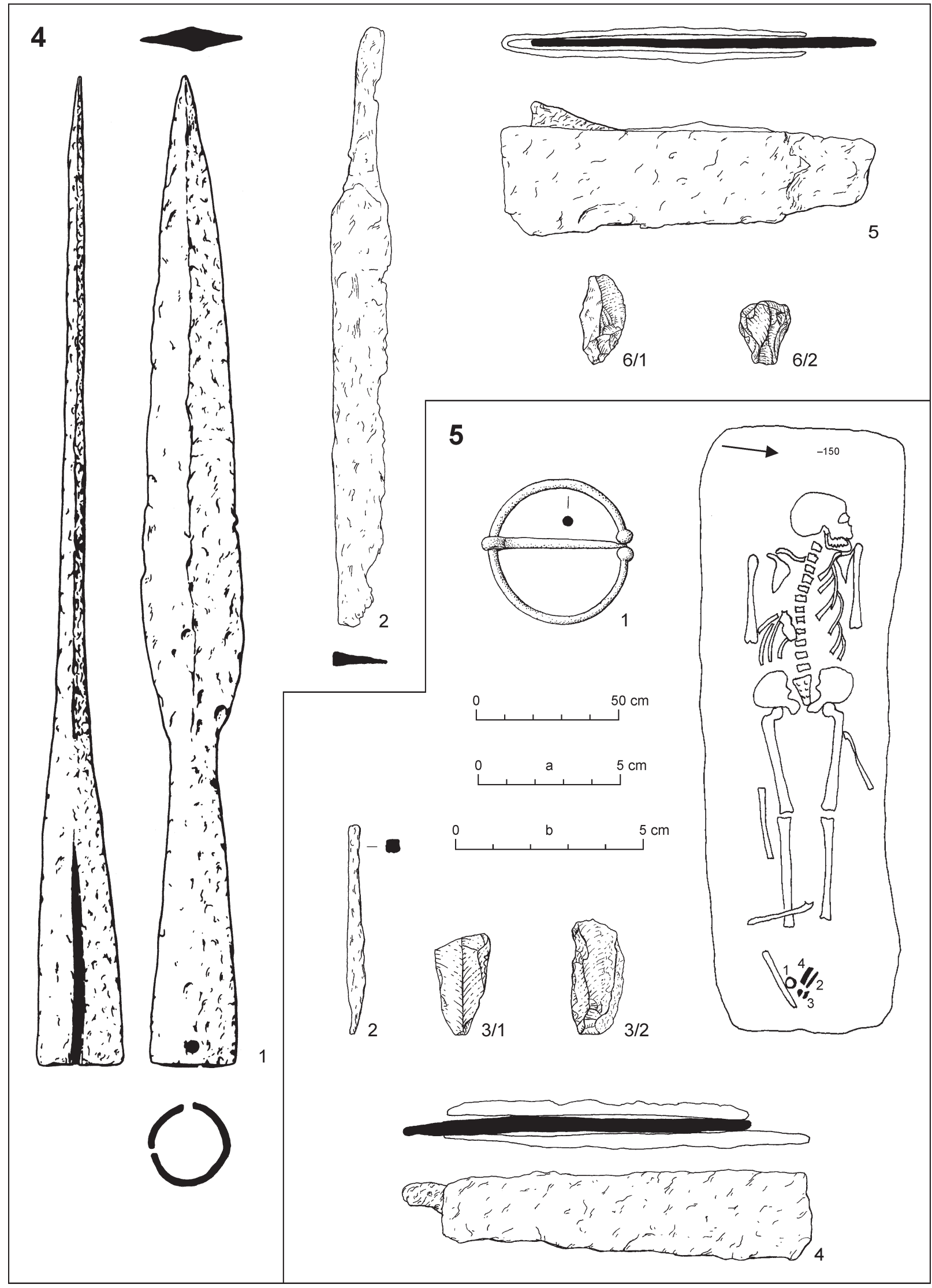

Tab. II. Hroby 4 a 5, plán a nálezy. Mierka: a - 4: 1; b - 4: 2, 5, 6, 5: 1-4. 


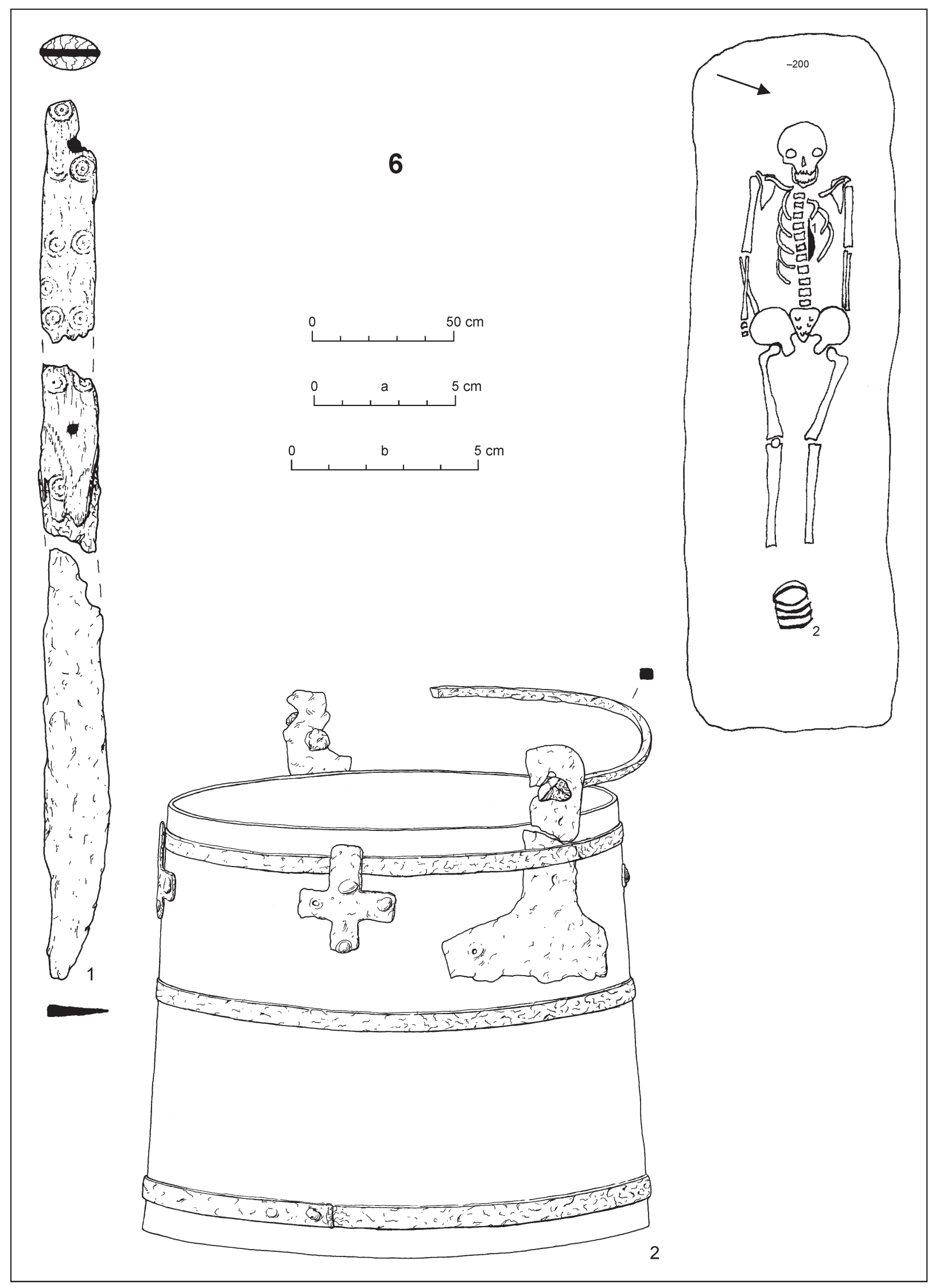

Tab. III. Hrob 6, plán a nálezy. Mierka: a - 6: 2; b - 6: 1 . 


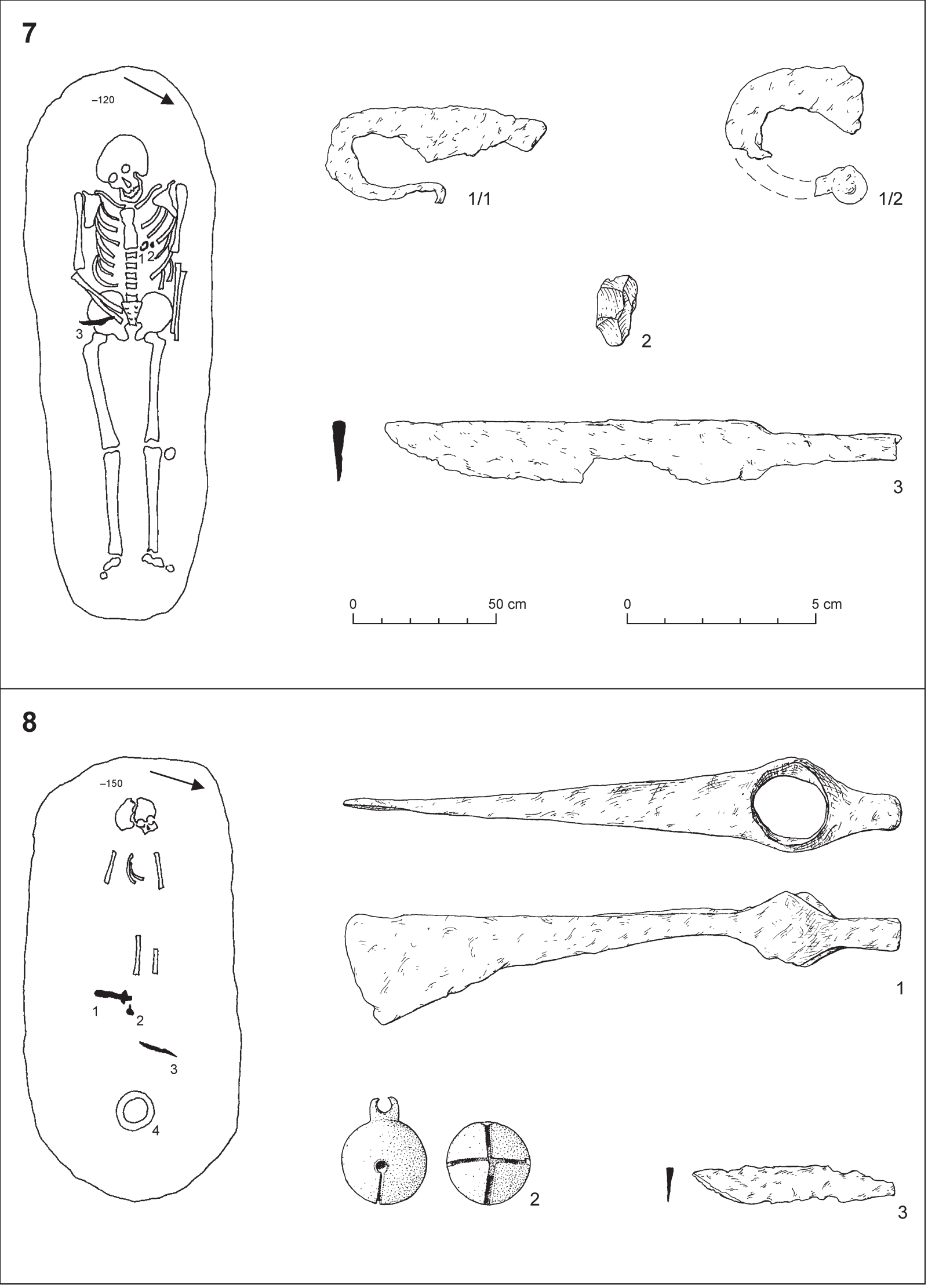

Tab. IV. Hroby 7 a 8, plány a nálezy. 


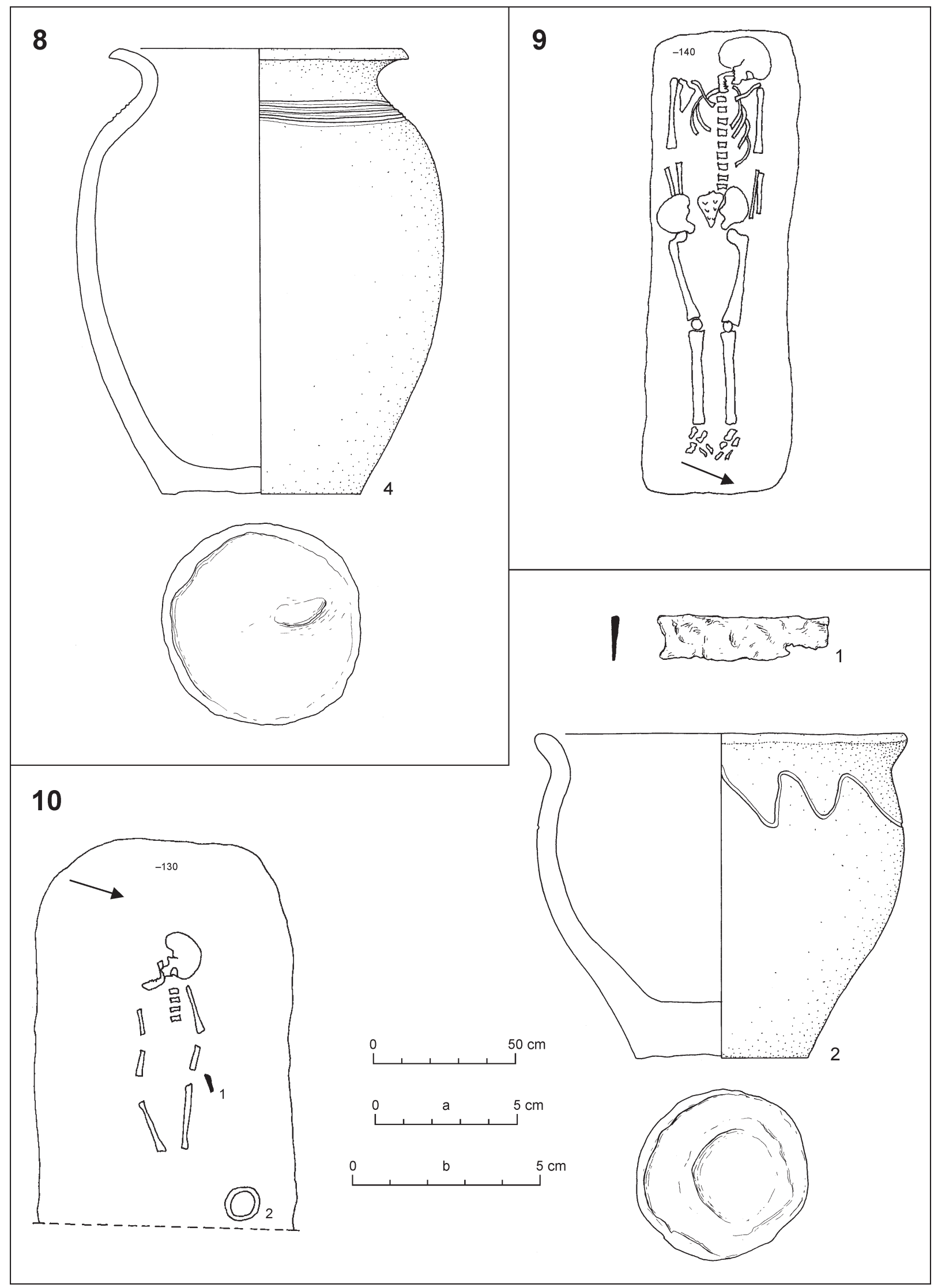

Tab. V. Hroby 8-10, plány a nálezy. Mierka: a - 8: 4, 10: 2; b - 10: 1 . 


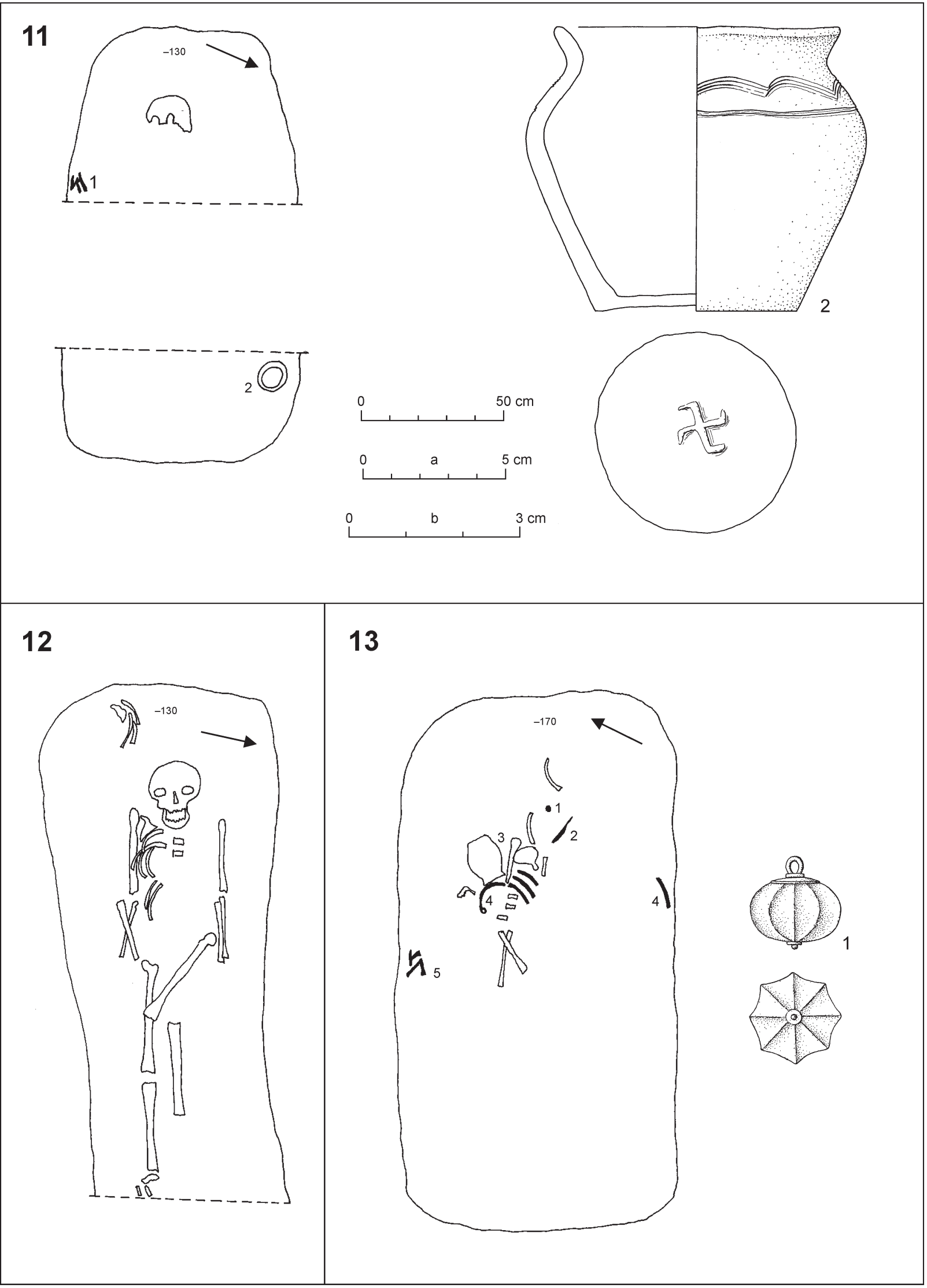

Tab. VI. Hroby 11-13, plány a nálezy. Mierka: a - 11: 2; b - 13: 1 . 


\section{3}
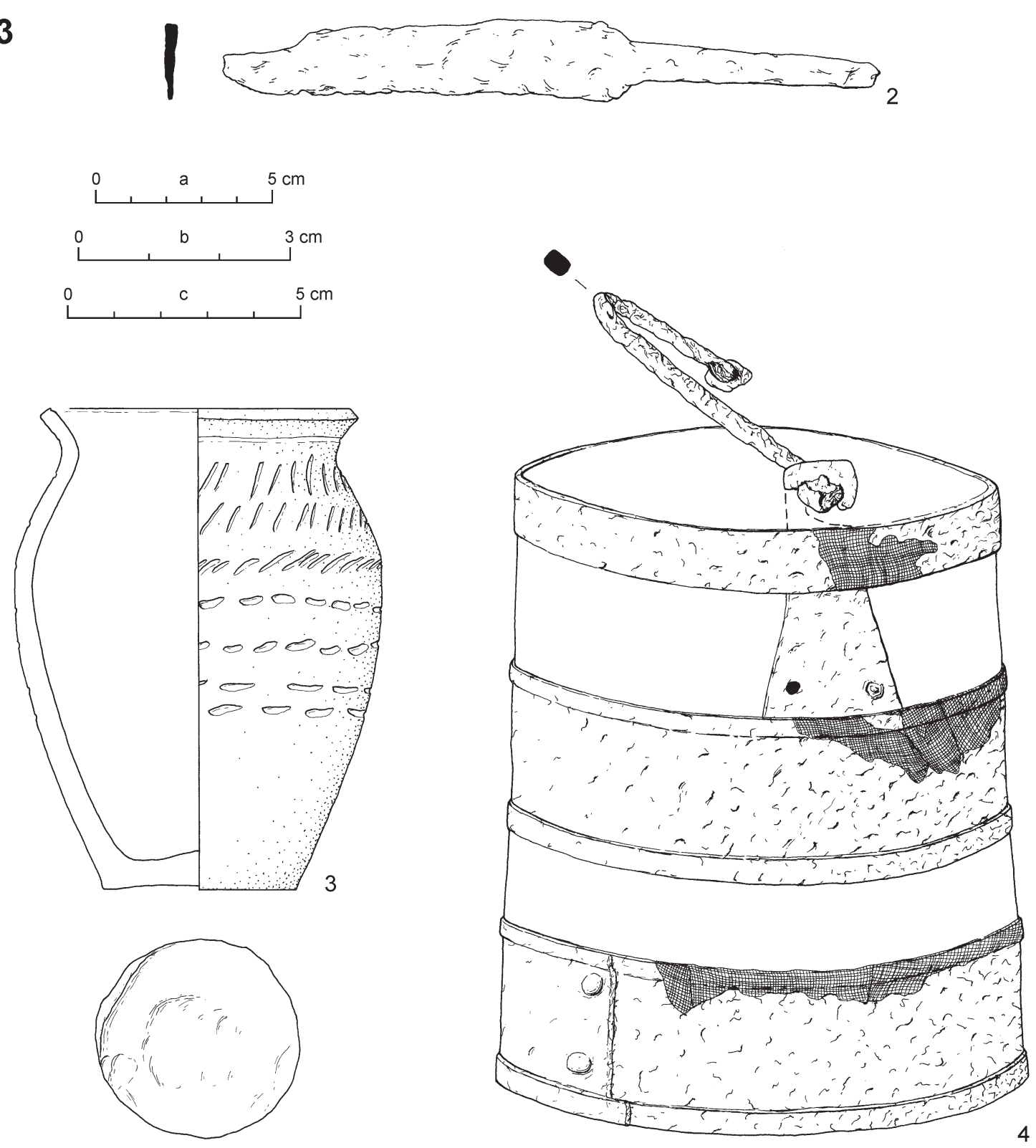

14
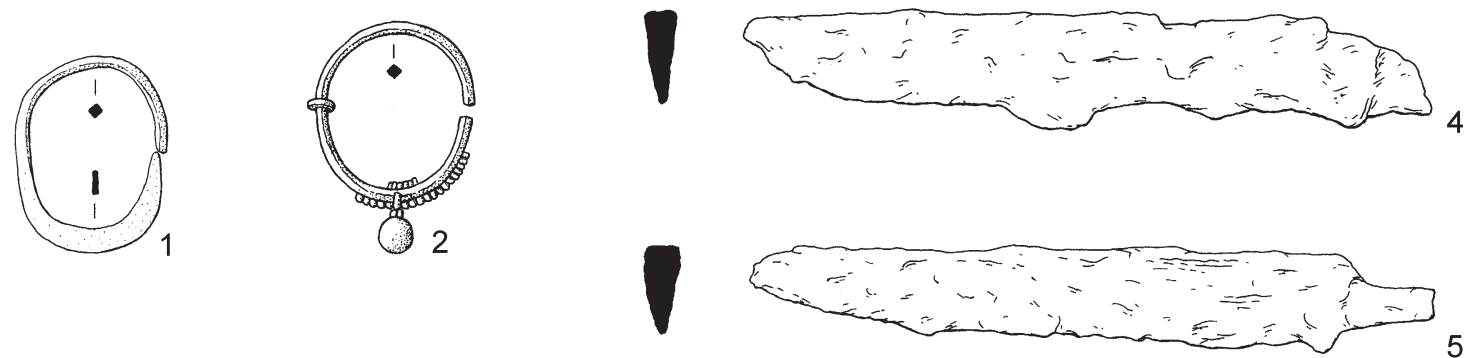

Tab. VII. Hroby 13 a 14, nálezy. Mierka: a - 13: 3, 4, b - 14: 1, 2; c - 13: 2, 14: 4, 5. 


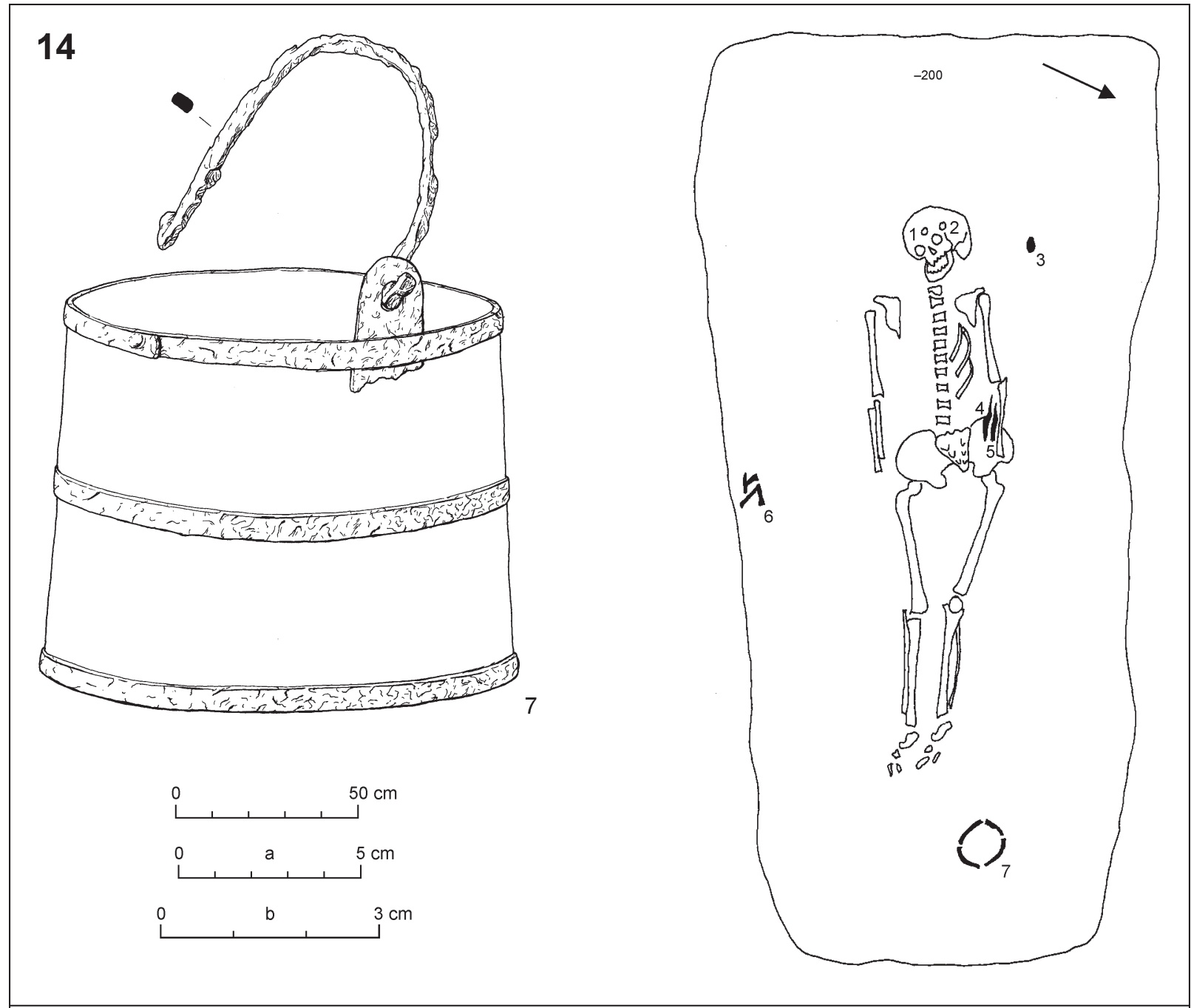

\section{6}
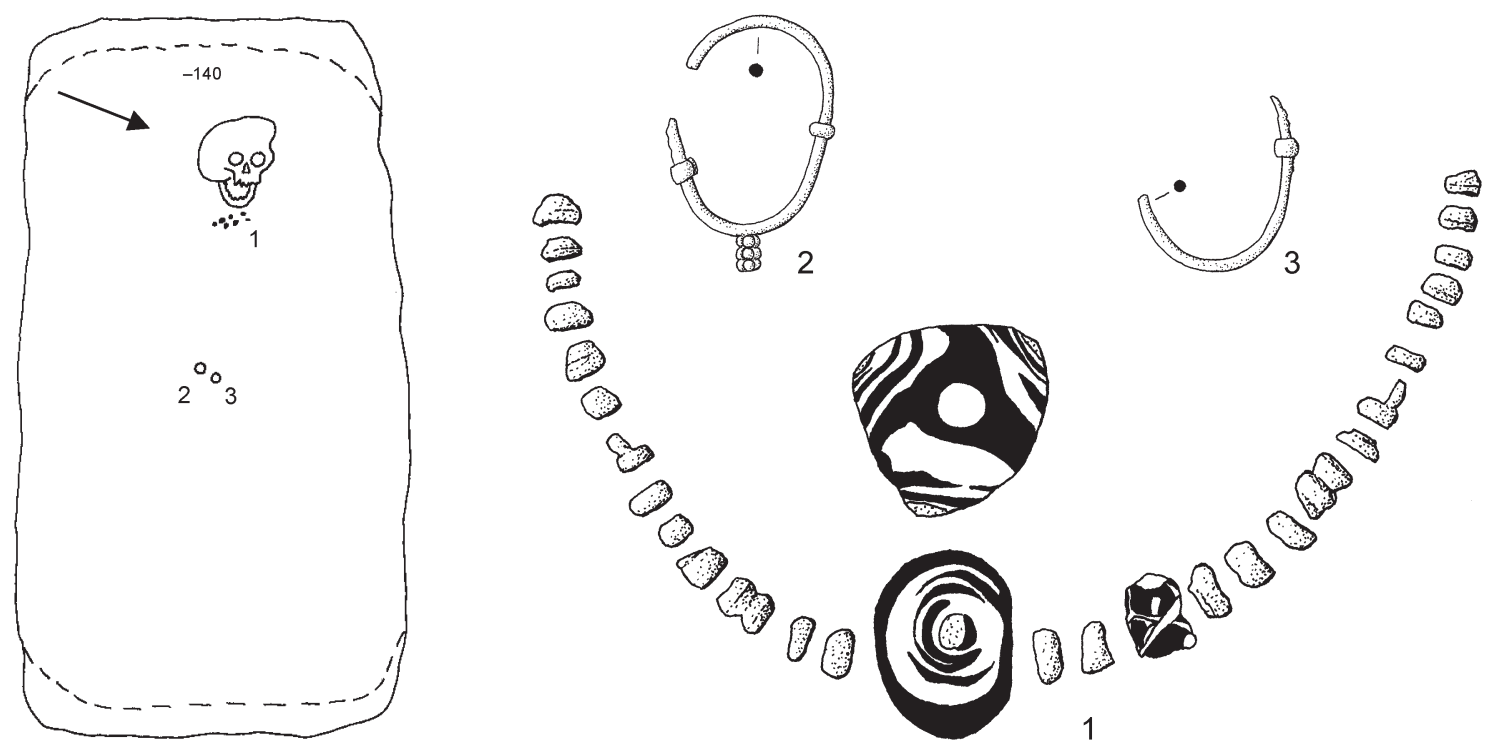

Tab. VIII. Hroby 14 a 16, plány a nálezy. Mierka: a - 14: 7; b - 16: 1-3. 


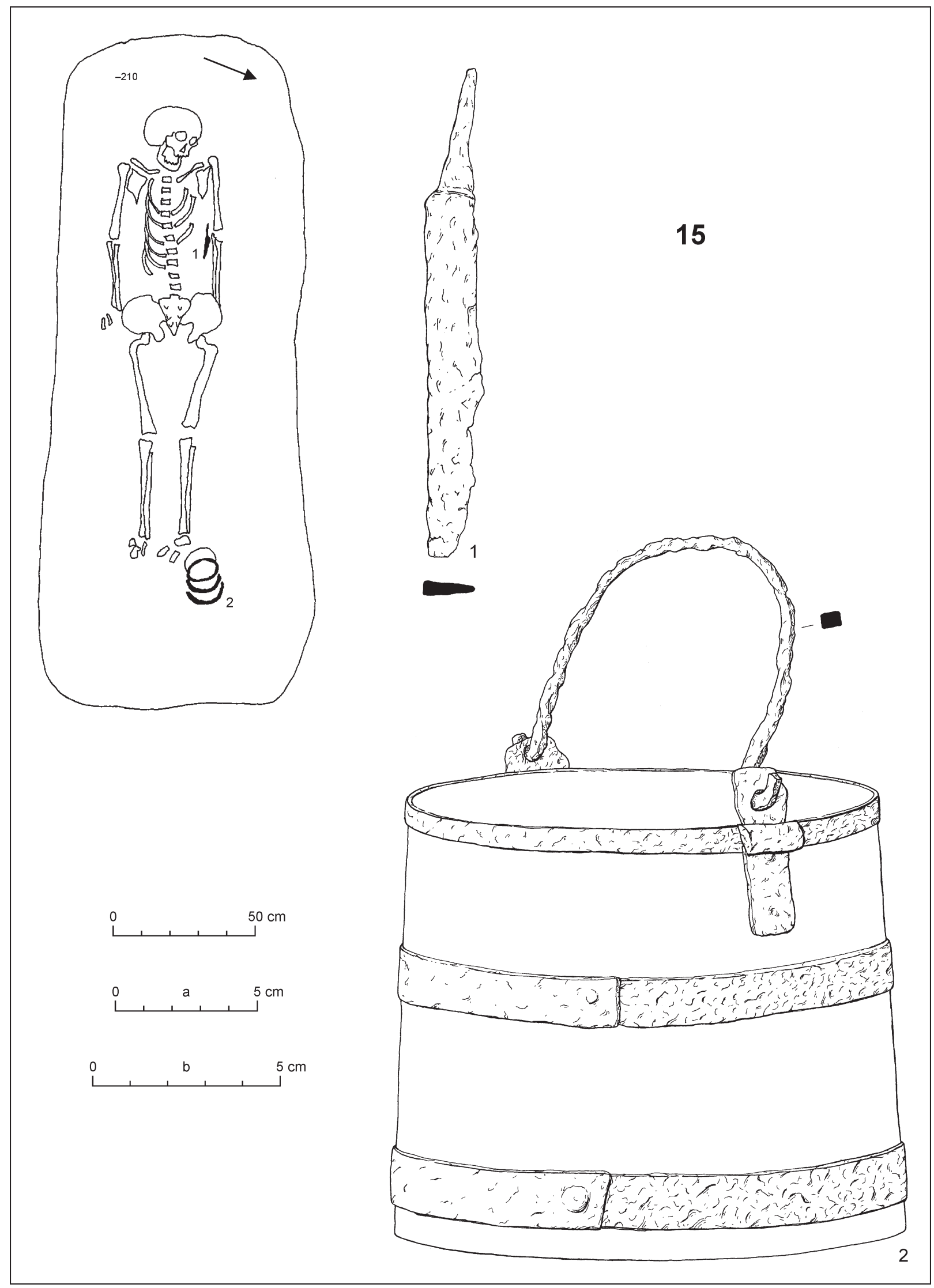

Tab. IX. Hrob 15, plán a nálezy. Mierka: a - 15: 2; b - 15: 1. 


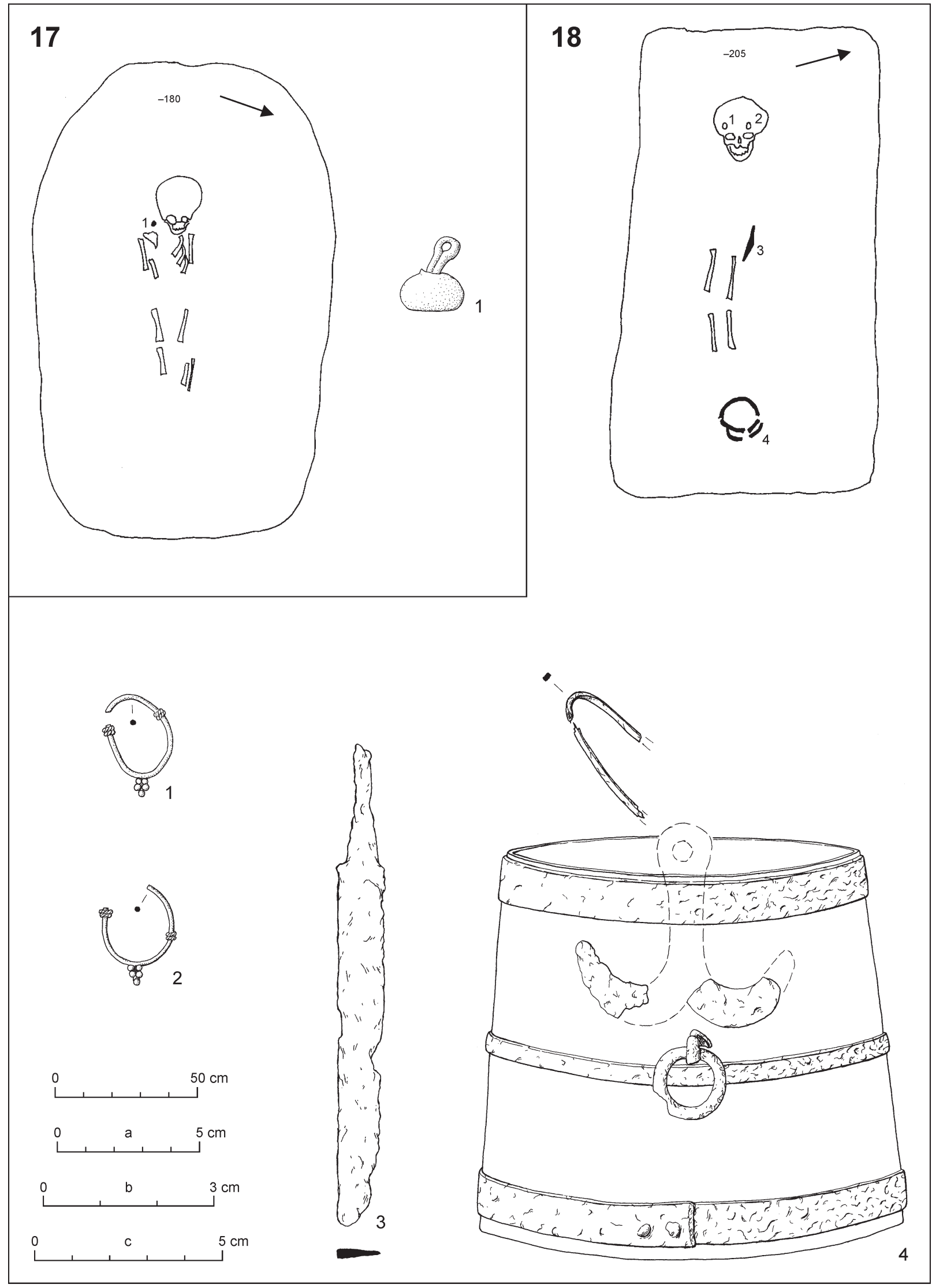

Tab. X. Hroby 17 a 18, plány a nálezy. Mierka: a - 18: 4; b - 17: 1, 18: 1, 2; c - 18: 3. 


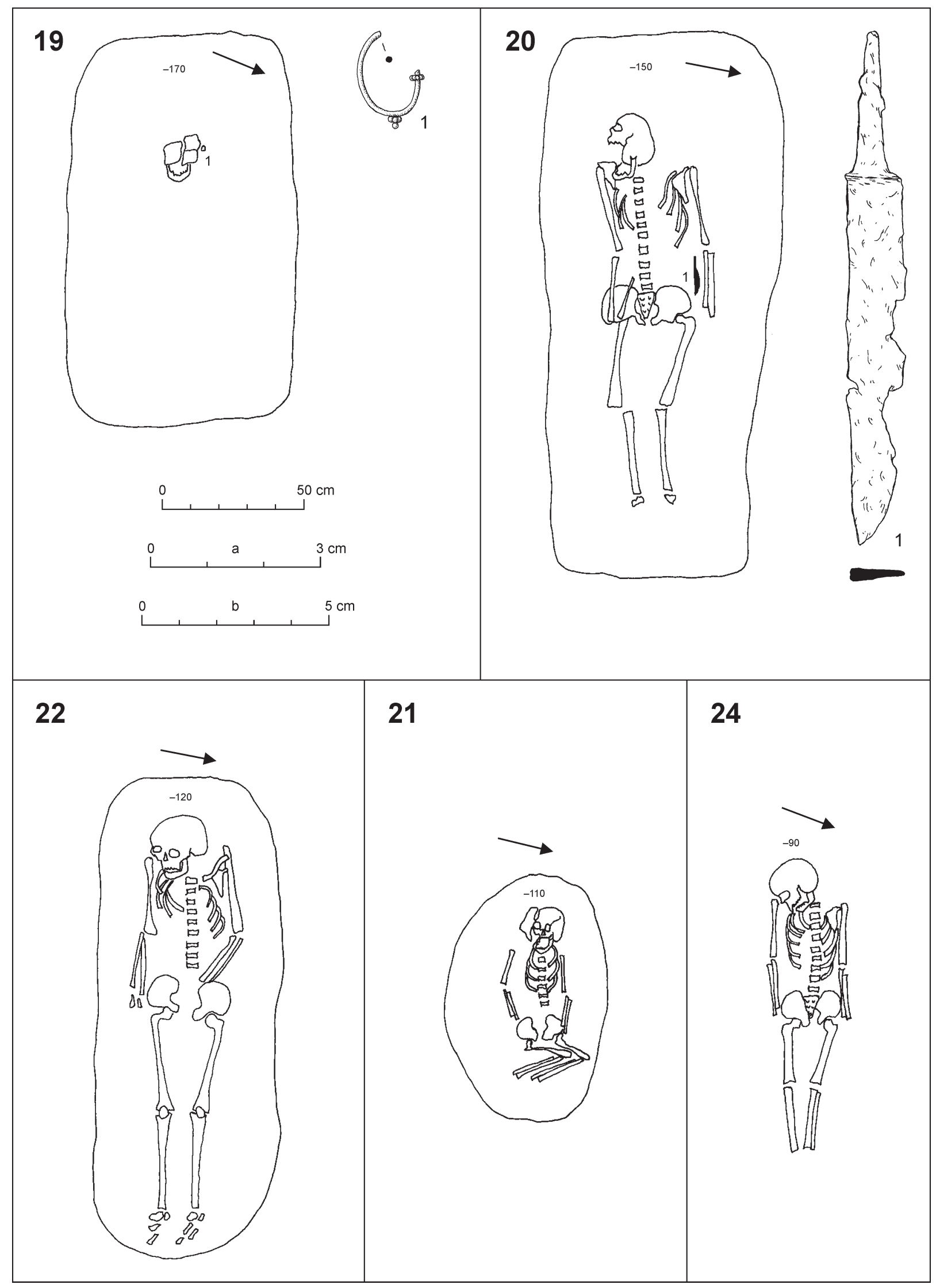

Tab. XI. Hroby 19-22, 24, plány a nálezy. Mierka: a - 19: 1; b - 20: 1. 


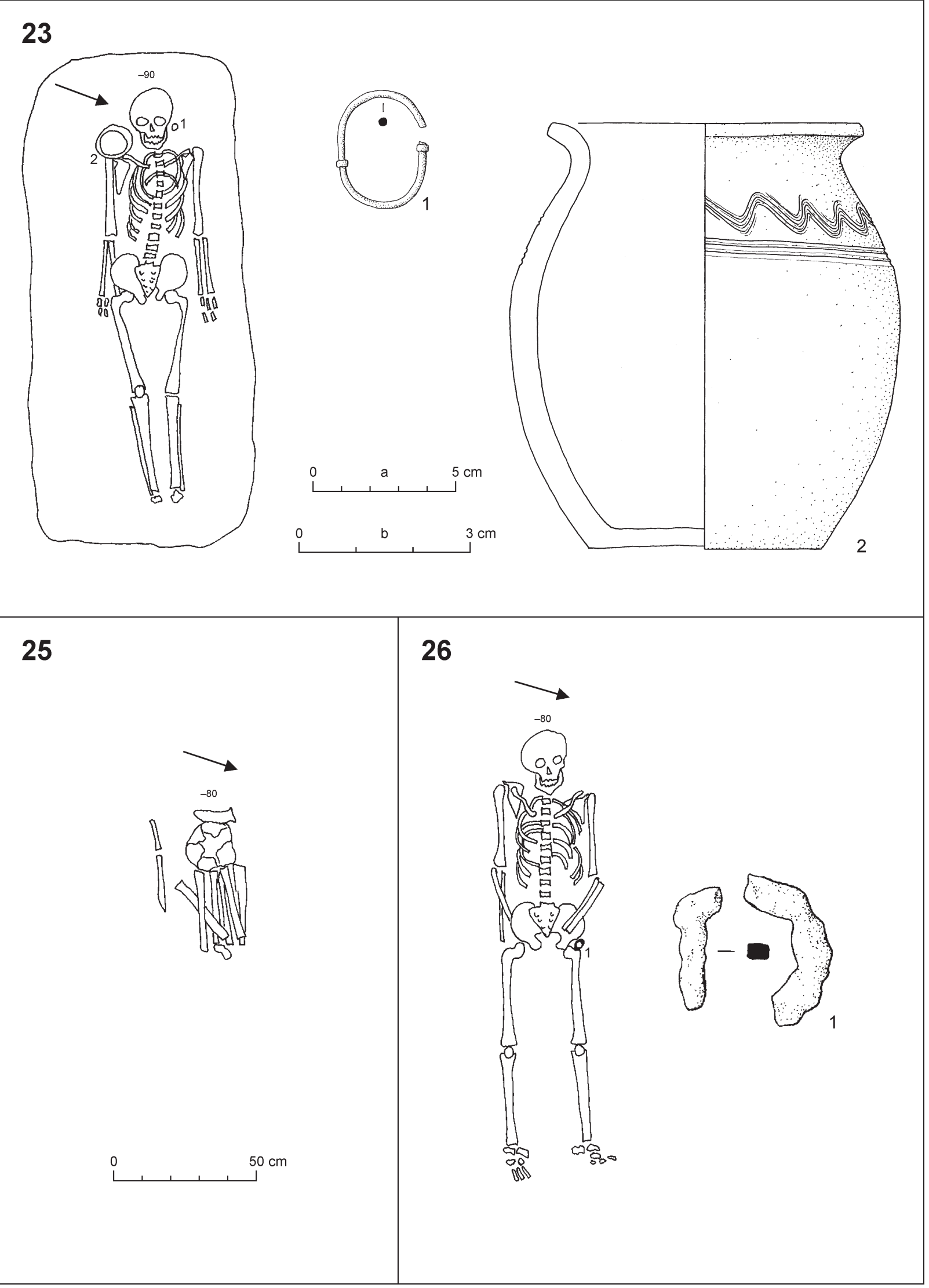

Tab. XII. Hroby 23, 25 a 26, plány a nálezy. Mierka: a - 23: 2; b - 23: 1, $26: 1$. 


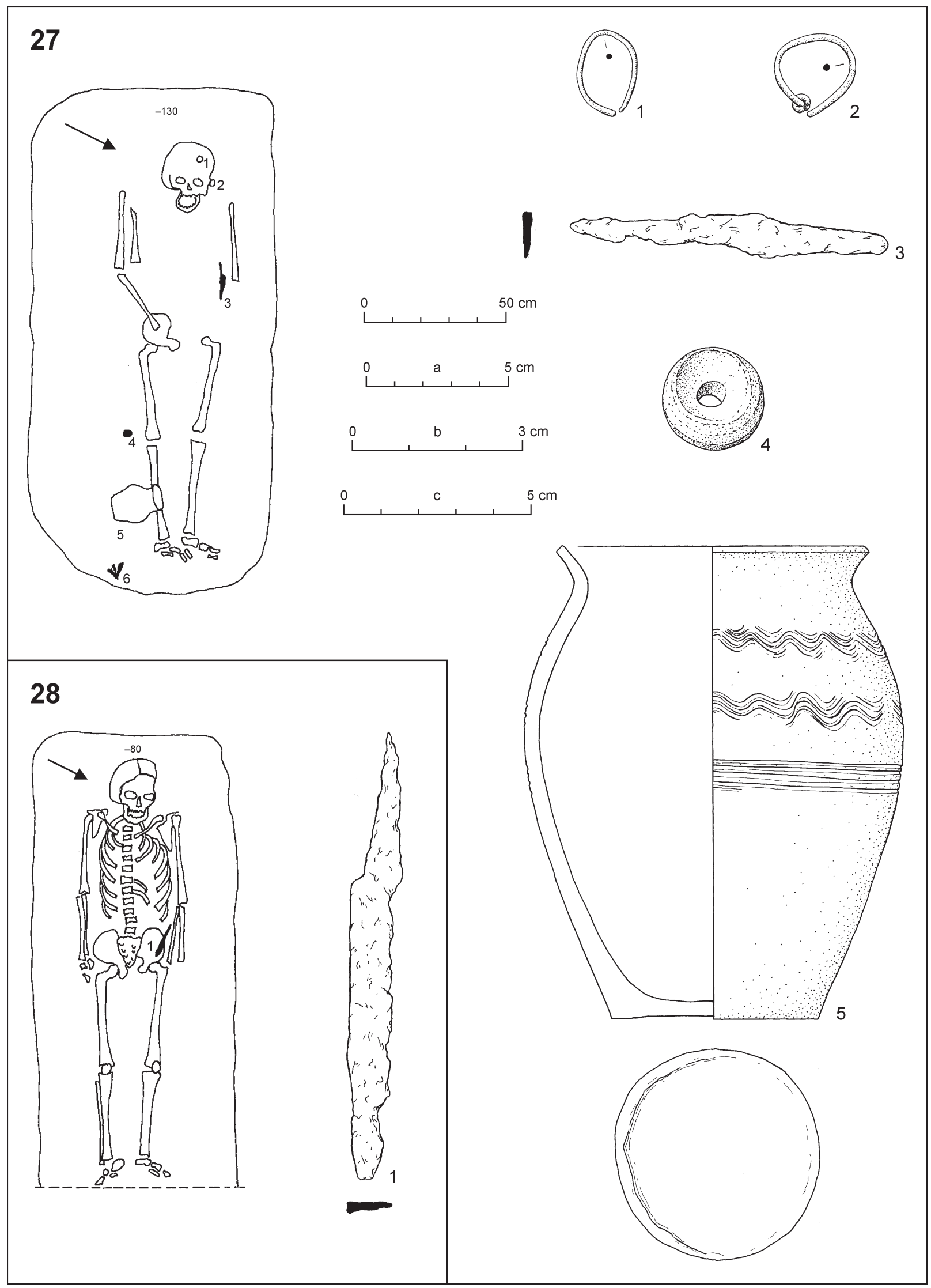

Tab. XIII. Hroby 27 a 28, plány a nálezy. Mierka: a - 27: 5; b - 27: 1, 2; c - 27: 3, 4, $28: 1$. 


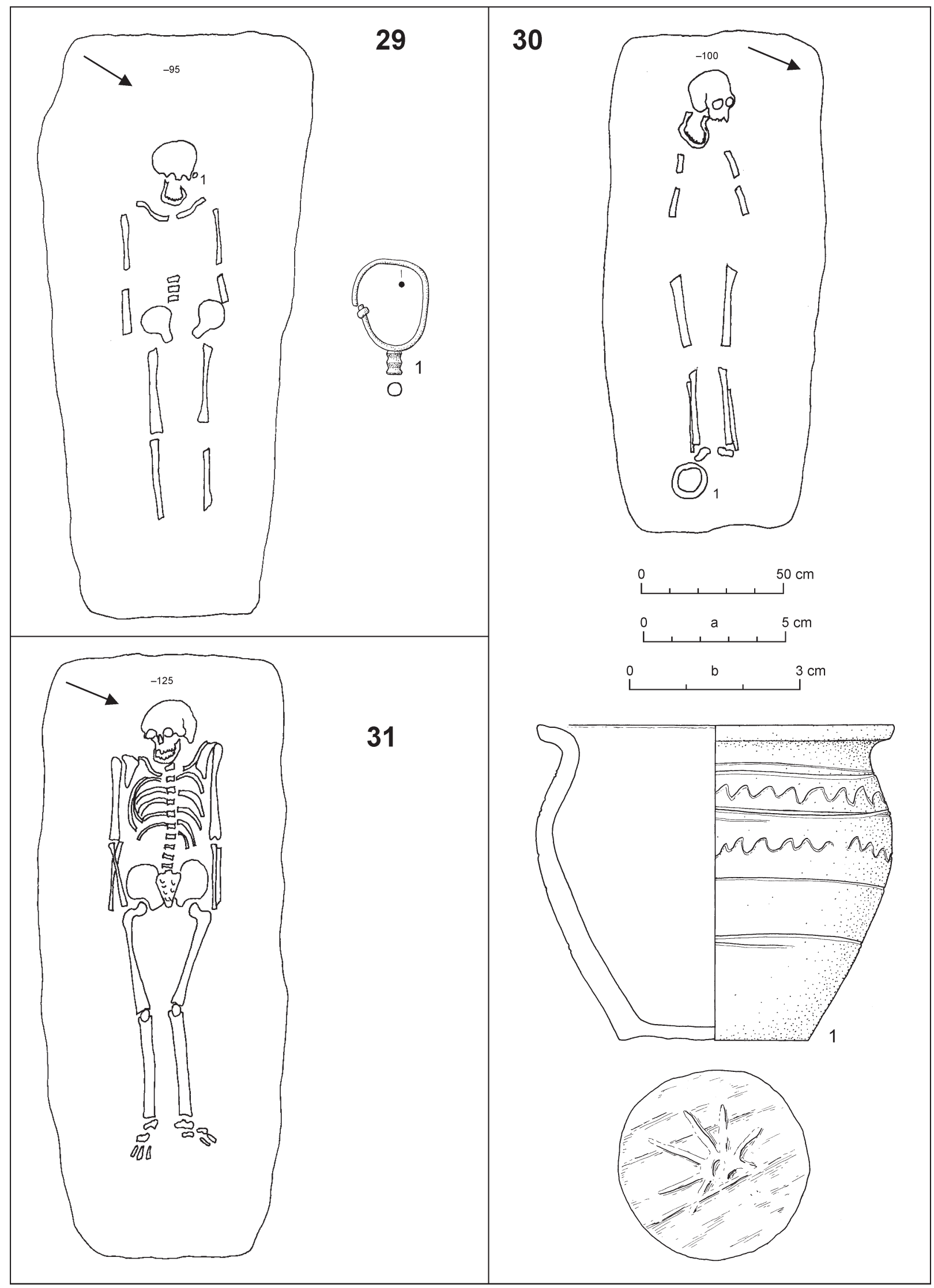

Tab. XIV. Hroby 29-31, plány a nálezy. Mierka: a - 30: 1; b - 29: 1. 


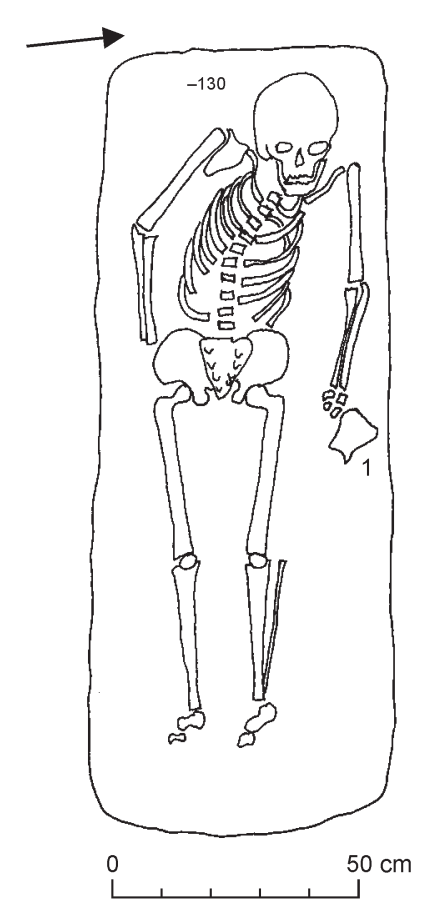

32
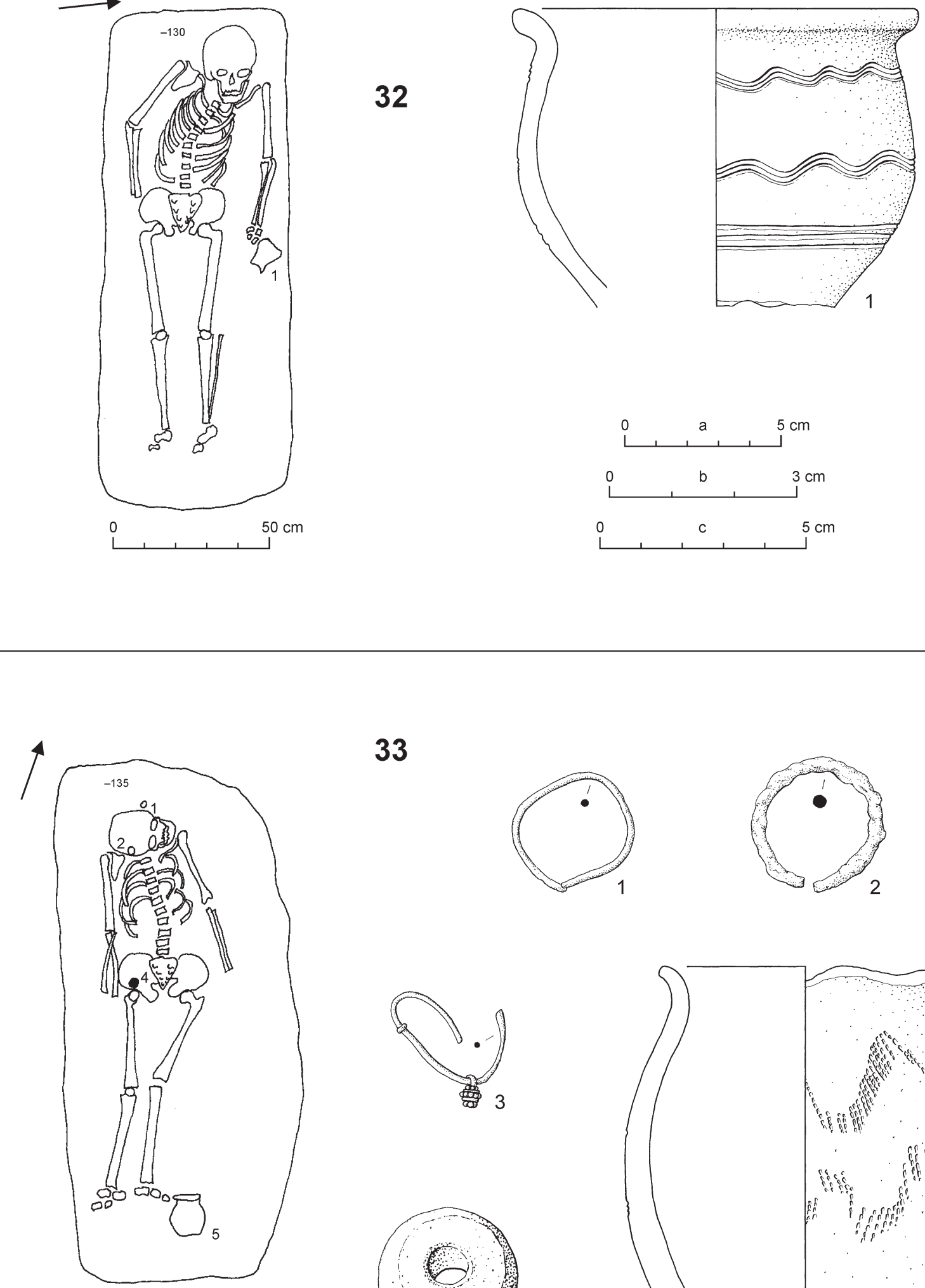

33
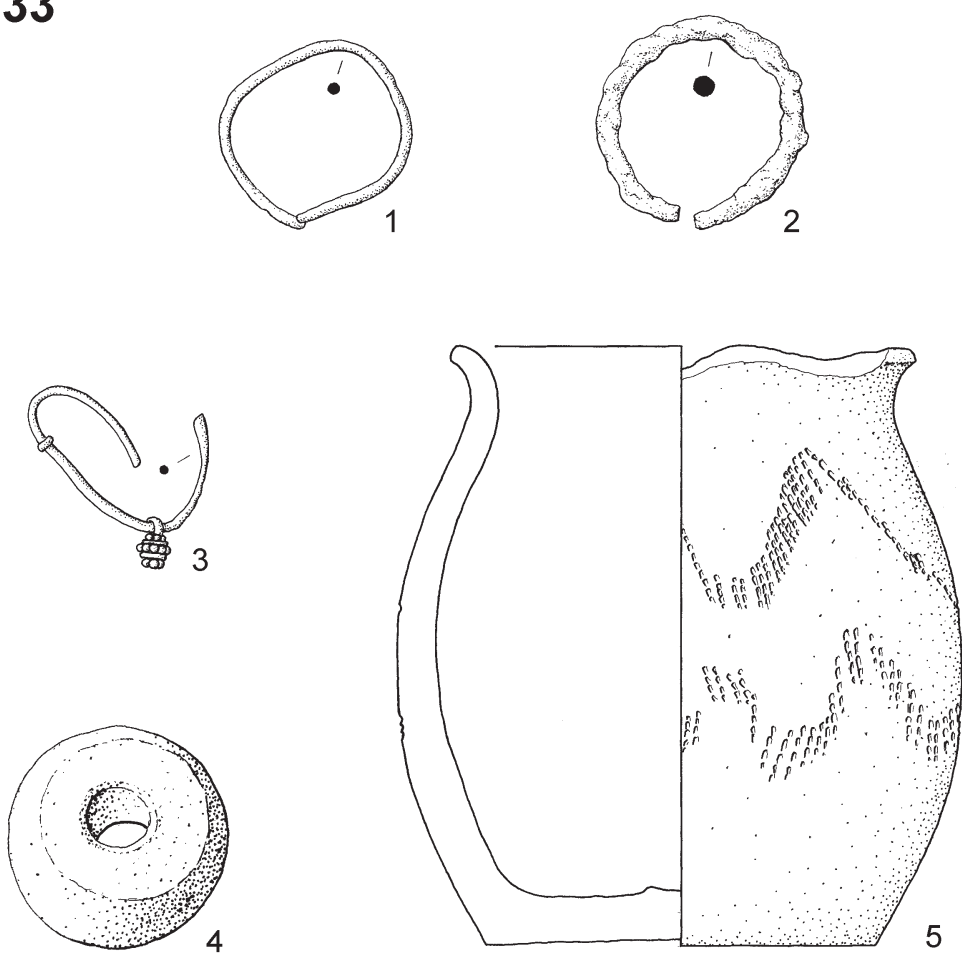

Tab. XV. Hroby 32 a 33, plány a nálezy. Mierka: a - 32: 1, 33: 5; b-33: 1-3; c - 33: 4. 


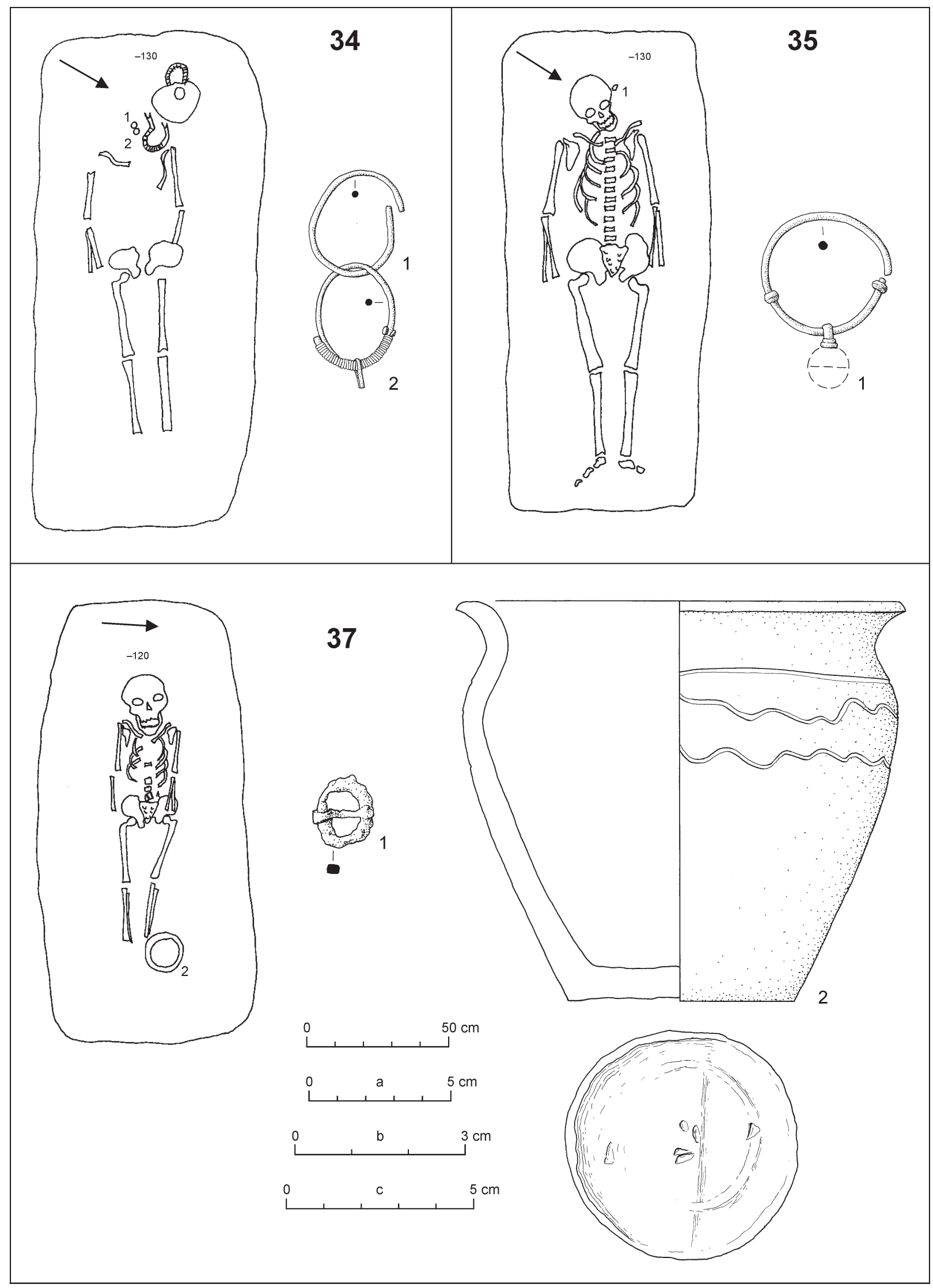

Tab. XVI. Hroby 34, 35 a 37, plány a nálezy. Mierka: a - 37: 2; b - 34: 1, 2, 35: 1; c - 37: 1. 


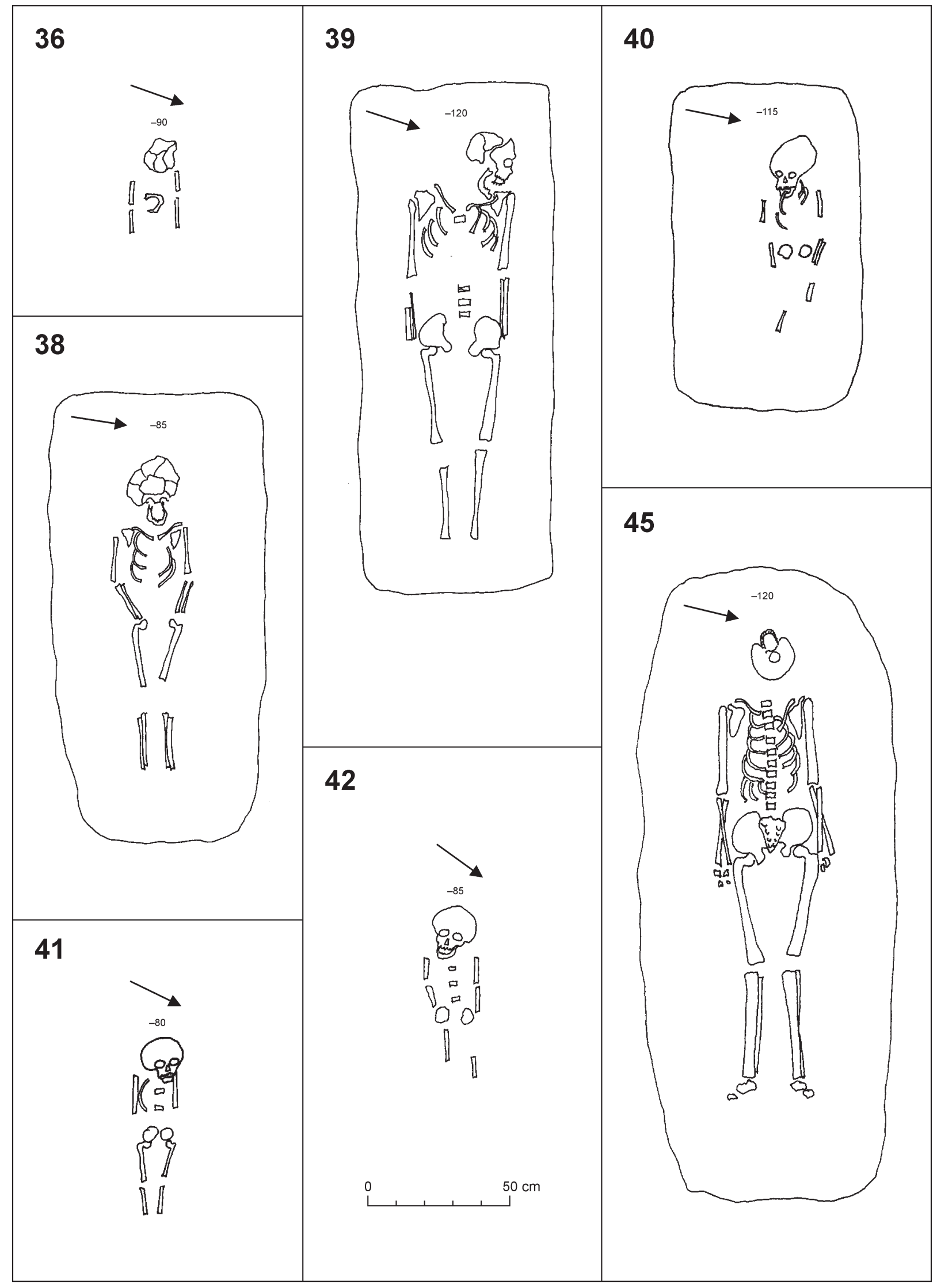

Tab. XVII. Hroby 36, 38-42 a 45, plány. 


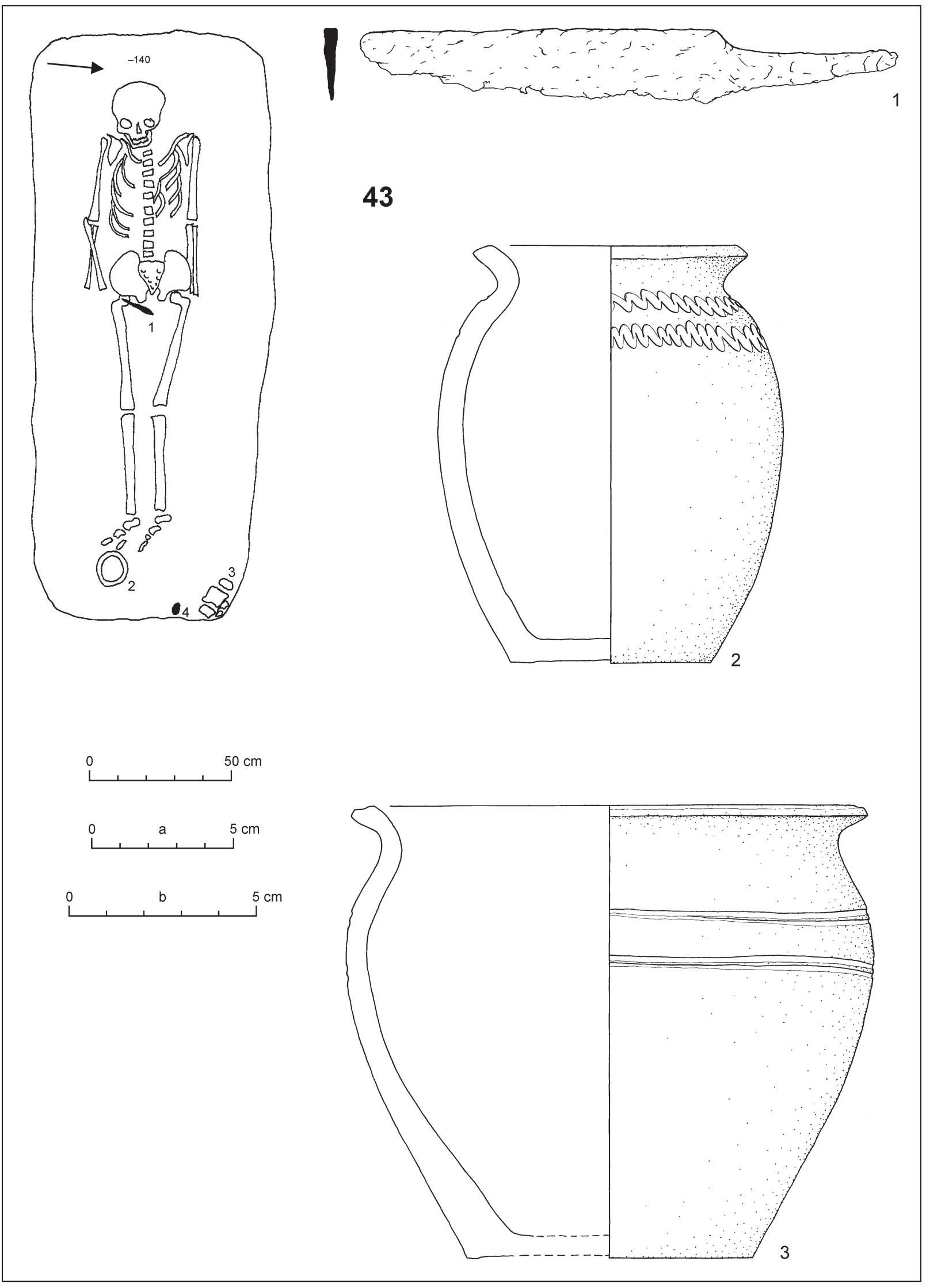

Tab. XVIII. Hrob 43, plán a nálezy. Mierka: a - 43: 2, 3; b - 43: 1. 


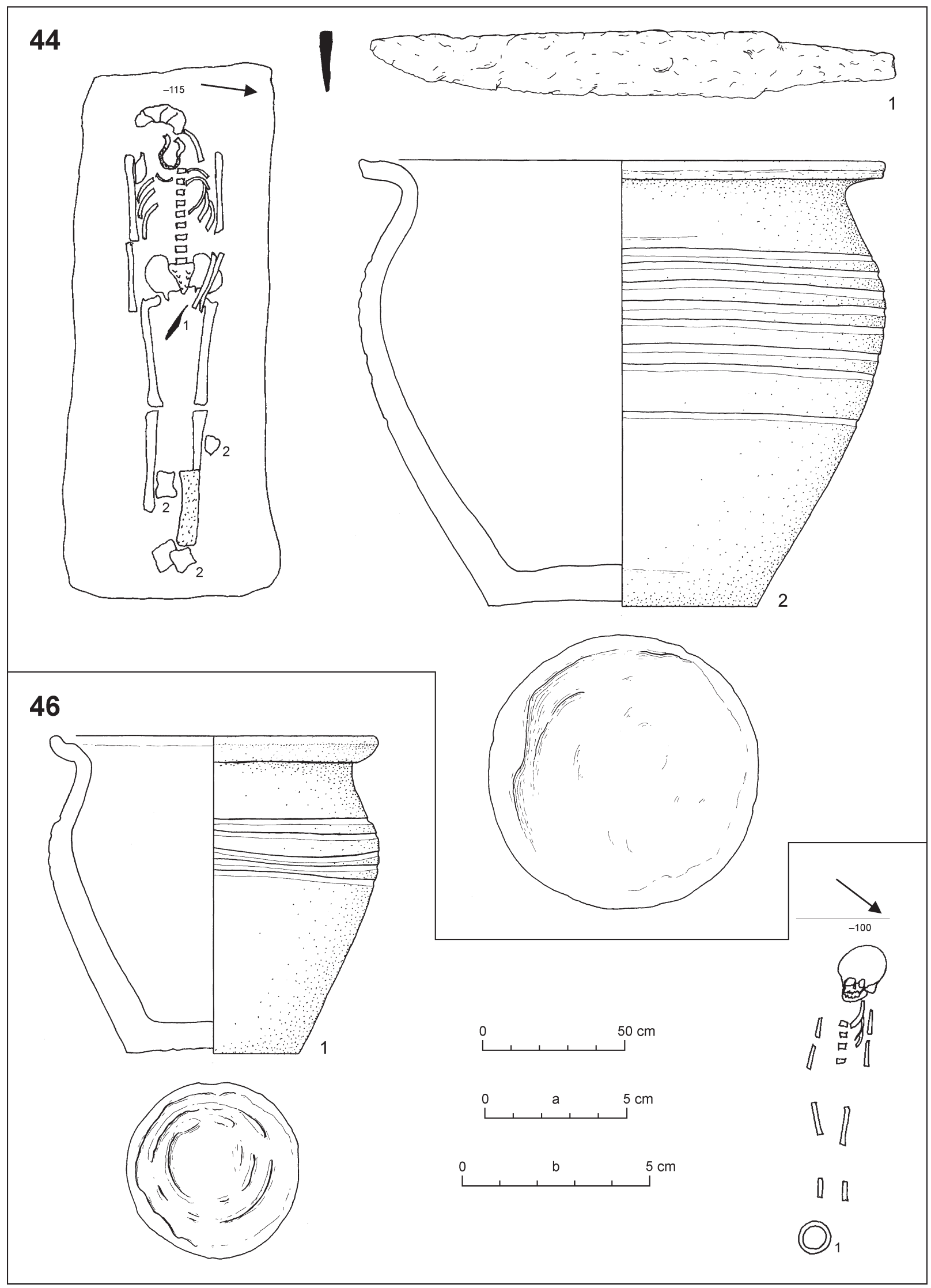

Tab. XIX. Hroby 44 a 46, plány a nálezy. Mierka: a - 44: 2; 46: 1; b - 44: 1 . 


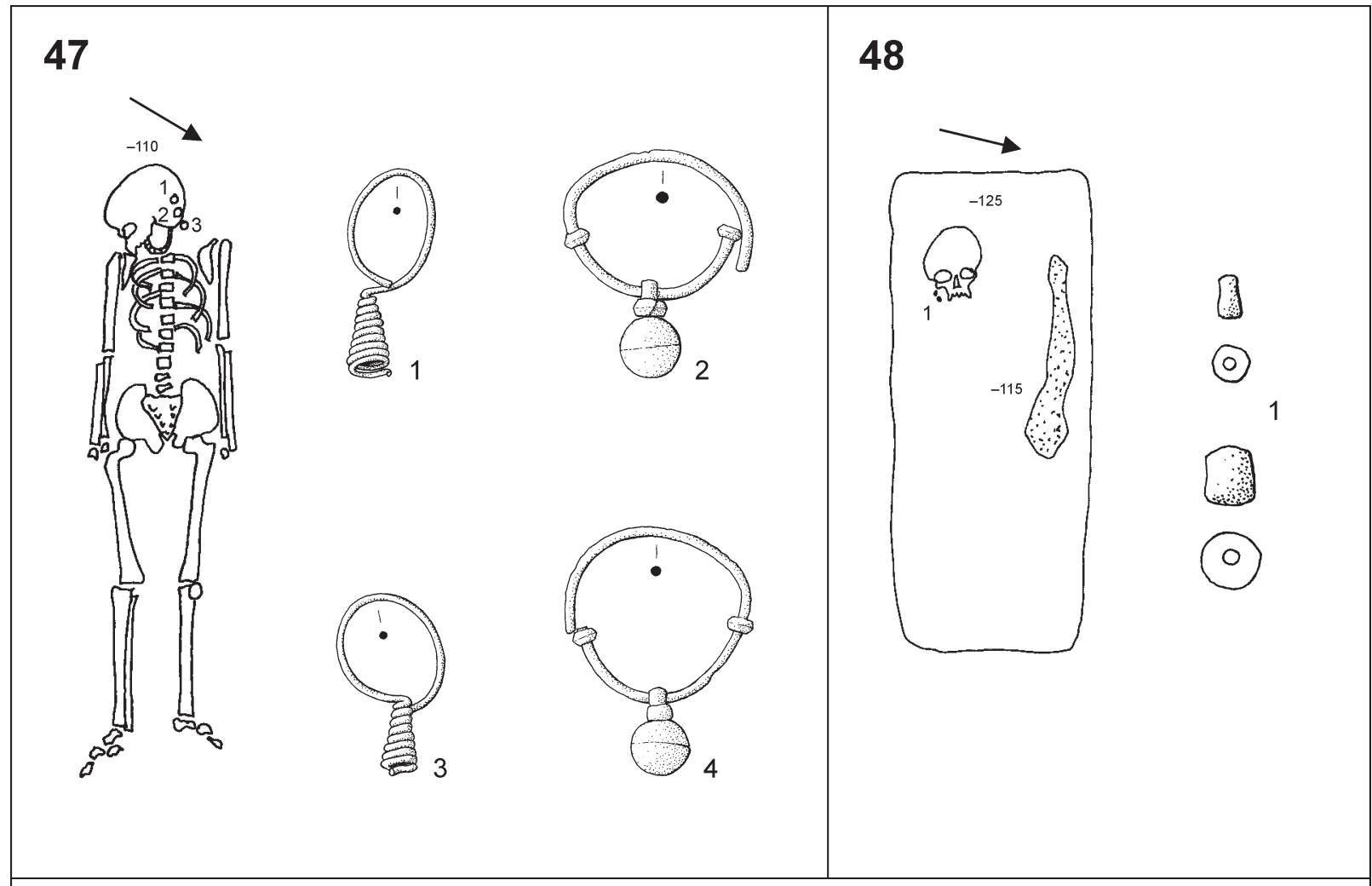

\section{9}
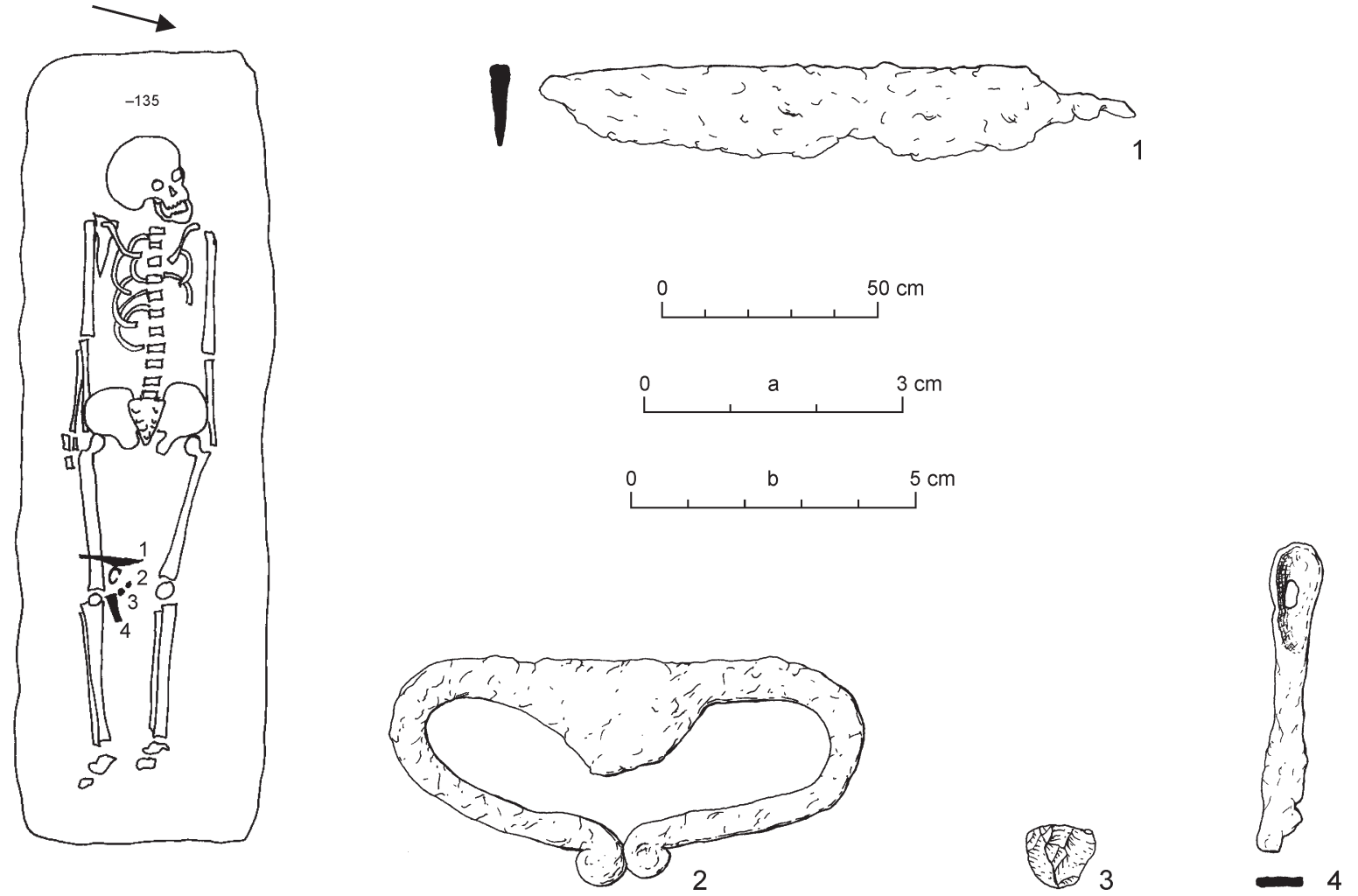

Tab. XX. Hroby 47-49, plány a nálezy. Mierka: a - 47: 1-4, 48: 1; b - 49: 1-4. 


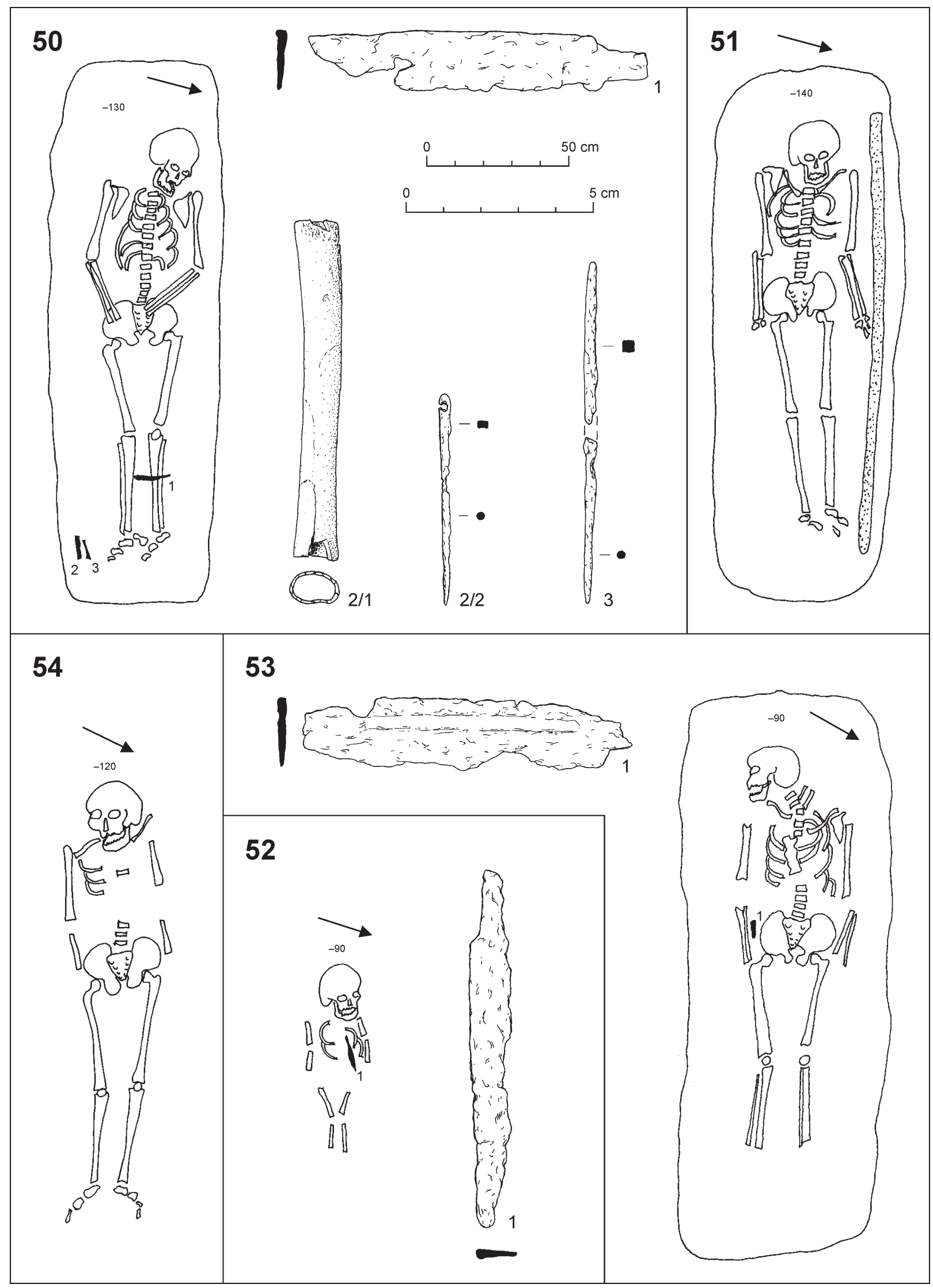

Tab. XXI. Hroby 50-54, plány a nálezy. 


\section{LITERATÚRA}

Aleškovskij 1960 - M. Ch. Aleškovskij: Kurgany russkich družinnikov XI-XII vv. Sovetskaja archeologija 1, 1960, 70-90.

Ariés 2000 - P. Ariés: Dějiny smrti. Praha 2000.

Bartošková 1986 - A. Bartošková: Slovanské depoty železných předmětů v Československu. Praha 1986.

Bednár 1998 - P. Bednár: Die Entwicklung der Befestigung der Nitraer Burg im 9.-12. Jahrhundert. In: J. Henning/A. T. Ruttkay (Hrsg.): Frühmittelalterlicher Burgenbau in Mittel- und Osteuropa. Tagung Nitra vom 7. bis 10. Oktober 1996. Bonn 1998, 371-382.

Bednár/Fottová 2003 - P. Bednár/E. Fottová: Nitra-tržnica príspevok k poznaniu zázemia stredovekého mesta. Archaeologia historica 28, 2003, 303-315.

Bednárik 1939 - R. Bednárik: Príspevok k pohrebným zvykom slovenského l'udu. Národopisný sborník 1, 1939, 54-94.

Béreš 1995 - J. Béreš: Slovanské pohrebisko v Dolnom Petre IV (teraz Svätý Peter). Slovenská archeológia 43, 1995, 111-158.

Bialeková 1990 - D. Bialeková: Sekerovité hrivny a ich väzba na ekonomické a sociálne prostredie Slovanov. In: L. Galuška (zost.): Staroměstská výročí. Brno 1990, 99-119.

Bialeková 1993 - D. Bialeková: Slovanské pohrebisko v Bojničkách. Študijné zvesti AÚ SAV 29, 1993, 223-254.

Březinová 2018 - G. Březinová: Šperk zo skla a sapropelitu u Keltov na Slovensku. Nitra 2018.

Budinský-Krička 1947 - V. Budinský-Krička: Nové nálezy kostrových hrobov z doby hradištnej na juhozápadnom Slovensku. Časopis Muzeálnej slovenskej spoločnosti 37-38, 1947, 33-40.

Budinský-Krička 1959 - V. Budinský-Krička: Slovanské mohyly v Skalici. Bratislava 1959.

Budinský-Krička/Točík 1991 - V. Budinský-Krička/A. Točík: Šebastovce. Gräberfeld aus der Zeit des awarischen Reiches. Katalog. Nitra 1991.

Bylina 1995 - S. Bylina: Problemy slowiańskiego świata zmarlych. Kategorie przestrzeni i czasu. Światowit 40, 1995, 9-25.

Csiky 2011-2012 - G. Csiky: Az Avar közelharci fegyverek története. Funkcionális megközelítes. Dolgozatok az Erdélyi Múzeum Érem-és Régiségtárából. Új sorozat VI-VII. (XVI-XVII.) kötet, 2011-2012, 71-97.

Čech/Kř́žek 1999 -Z. J. K. Čech/L. Křížek: Encyklopedie zbraní a zbroje. Libri 1999.

Černý 1995 - V. Černý: Význam tafonomických procesů při studiu pohřebního ritu. Archeologické rozhledy 47, 1995, 301-313.

Čilinská 1975 - Z. Čilinská: Frauenschmuck aus dem 7.-8. Jahrhundert im Karpatenbecken. Slovenská archeológia 23, 1975, 63-96.

Daňová/Ruttkay, M. 2011 - K. Daňová/M. Ruttkay: Porušovanie hrobov v 11. storočí na pohrebisku v Nitre-Selenci. In: S. Stuchlík (ed.): Materiály o pohřebním ritu. Druhotné zásahy v hrobech. Acta archaeologica Opaviensia 4. Opava 2011, 161-167.

Dočkalová 2004 - M. Dočkalová: Tafonomické aspekty v osteologické archeologii. Ve službách archeologie 5, 2004, 214-222.

Dočkalová 2005 - M. Dočkalová: Antropologická metodika zpracování hromadných hrobů. Ve službách archeologie 6, 2005, 331-344.
Dostál 1966 - B. Dostál: Slovanská pohřebiště ze střední doby hradištní na Moravě. Praha 1966.

Dostál 1975 - B. Dostál: Břeclav-Pohansko IV. Velkomoravský velmožský dvorec. Brno 1975.

Dostál 1982 - B. Dostál: Drobná pohřebiště a rozptýlené hroby z Břeclavi-Pohanska. Sborník Prací Filosofické Fakulty Brněnské University E 27, 1982, 135-201.

v. Dülmen 1999 - R. van Dülmen: Kultura a každodenní život v raném novověku (16.-18. století). Praha 1999.

Eisner 1966-J. Eisner: Rukovět' slovanské archeologie. Praha 1966.

Fottová 2019 - E. Fottová: Typologicko-chronologický vývoj keramiky 8.-12. storočia v oblasti Nitra. Dizertačná práca AÚ SAV. Nitra 2019. Nepublikované.

Frolík 2013 - J. Frolík: Pohřebiště na II. nádvoří Pražského hradu. Archaeologia historica 29/1, 2013, 91-105.

Frolik 2014 - J. Frolík: Pohřebiště v Lumbeho zahradě, analýza, chronologie, význam. In: J. Frolík (ed.): Pohřebiště v Lumbeho zahradě na Pražském hradě II. Castrum Pragense 12. Praha 2014, 5-116.

Frolíková-Kaliszová 2000 - D. Frolíková-Kaliszová: Pokus o analýzu slovanského pohřebiště v Praze-Motole. Památky archeologické 91, 2000, 201-249.

Frolíková-Kaliszová 2009 - D. Frolíková-Kaliszová: Hrnce, hrnky, hrnečky. In: P. Dresler/Z. Měřínský (ed.): Archeologie doby hradištní v České a Slovenské republice. Archaeologia Mediaevalis Moravica et Silesiana. Supplementum 2. Brno 2009, 93-98.

Frolíková-Kaliszová 2014 - D. Frolíková-Kaliszová: Pohřebiště z 10. století v Praze-Střešovicích - Předběžná zpráva. Archaeologia historica 29, 2014, 315-329.

Fusek 2006 - G. Fusek: Výklenkové hroby na včasnostredovekom pohrebisku v Cíferi, čast' Pác. Študijné zvesti AÚ SAV 39, 2006, 27-54.

Fusek 2009 - G. Fusek: Odtlačky na dnách nádob v Nitre-Šindolke. In: P. Dresler/Z. Měřínský (ed.): Archeologie doby hradištnív Českéa Slovenské republice. Archaeologia Mediaevalis Moravica et Silesiana. Supplementum 2. Brno 2009, 99-108.

Fusek 2011 - G. Fusek: Zásahy do hrobov belobrdskej kultúry v Nitre-Šindolke. In: S. Stuchlík (ed.): Materiály o pohřebním ritu. Druhotnézásahy v hrobech. Acta archaeologica Opaviensia 4. Opava 2011, 119-124.

Le Goff/Schmitt 1999 - J. Le Goff/J.-C. Schmitt: Encyklopedie středověku. Praha 1999.

Galuška 1996 - L. Galuška: Uherské Hradiště-Sady. Křestanské centrum řiše velkomoravské. Brno 1996.

Galuška 2006 - L. Galuška: Depot raně středověkých železných předmětů od Býčí skály v Moravském krasu. In: J. Zábojník (red.): Aevum Medium. Zborník na počest' Jozefa Hošša. Bratislava 2006, 23-29.

Galuška 2013 - L. Galuška: Hledání původu. Od avarských bronzů ke zlatu Velké Moravy. Brno 2013.

Galuška 2017 - L. Galuška: Slované - stopy předků. O Moravě v 6.-10. století. Brno 2017.

Geisler 1984 - M. Geisler: Slovanské kostrové hroby z Tvarožné (okr. Brno-venkov). Archeologické rozhledy 36, 1984, 490-497.

Gladykowska-Rzeczycka 2004 - J. J. Gladykowska-Rzeczycka: Los dzieci - zagrozenia, choroby - znany ze zródel pisanych i paleoantropologiznych. In: W. Dzeieduszycki/J. Wrzesziński (red.): Dusza maluczka a strata ogromna. Funeralia Lednickie 6. Poznań 2004, 61-69. 
Hanuliak 1989 - M. Hanuliak: Okres Nitra. In: D. Bialeková (zost.): Pramene k dejinám osídlenia Slovenska z konca 5 až z 13. storočia. I/1. Nitra 1989, 179-236.

Hanuliak 1993 - M. Hanuliak: Pohrebisko slovanskej populácie z 10. storočia v Bučanoch. Slovenská archeológia 41, 1993, 83-112.

Hanuliak 1994 - M. Hanuliak: Malé Kosihy I. Pohrebisko z 10.-11. storočia (Archeologicko-historické vyhodnotenie). Nitra 1994.

Hanuliak 2001 - M. Hanuliak: Vel'komoravské pohrebiská na Slovensku. Databáza prameňov. Nitra 2001. Nepublikovaný rukopis.

Hanuliak 2002 - M. Hanuliak: Pohrebiská a spôsoby pochovávania vo vel'komoravskom období. In: A. Ruttkay/ M. Ruttkay/P. Šalkovský (ed.): Slovensko vo včasnom stredoveku. Nitra 2002, 81-88.

Hanuliak 2004a-M. Hanuliak: Charakter a význam hraníc $\mathrm{v}$ časopriestorovej dimenzii pohrebného rítu z mladšieho úseku včasného stredoveku. Archaeologia historica 29, 2004, 37-50.

Hanuliak 2004b - M. Hanuliak: Vel'komoravské pohrebiská. Pochovávanie v 9.-10. storočí na území Slovenska. Nitra 2004.

Hanuliak 2004c-M. Hanuliak: Predmety pravekej a včasnohistorickej proveniencie na nekropolách z územia Slovenska. Študijné zvesti AÚ SAV 36, 2004, 25-34.

Hanuliak 2005 - M. Hanuliak: Skizze der Struktur der großmährischen Gesellschaft auf Grund des Gräberfeldmaterials auf dem Gebiet der Slowakei. In: Kouřil 2005b, 271-282.

Hanuliak 2006 - M. Hanuliak: Detskí jedinci vo vel'komoravskom prostredí na základe pohrebiskových prameňov z územia Slovenska. Slovenská archeológia 54, 2006, 259-284.

Hanuliak 2007 - M. Hanuliak: Duchovná zložka každodenného života vel'komoravských Slovanov. In: E. Nemcová/J. Píšová (ed.): Cyril a Metod - Slovensko a Európa. Trnava 2007, 80-91.

Hanuliak 2008a - M. Hanuliak: Materiálna podstata v duchovnej kultúre vel'komoravských Slovanov. Konštantínove listy 1, 2008, 26-40.

Hanuliak $2008 b$ - M. Hanuliak: Porušovanie telesných zvyškov zomrelých vo vel'komoravskom prostredí z územia Slovenska. Slovenská archeológia 54, 2008, $143-166$

Hanuliak 2011 - M. Hanuliak: Princípy porušovania zomrelých v 9.-10. storočí na Slovensku. In: S. Stuchlík (ed.): Materiály o pohřebním ritu. Druhotné zásahy $v$ hrobech. Acta archaeologica Opaviensia 4. Opava 2011, 125-139.

Hanuliak 2014 - M. Hanuliak: Sídlisko z poslednej tretiny 10. stor. v Orechovom sade z Mužle-Cenkova. Archaeologia historica 39, 2014, 679-688.

Hanuliak/Chropovský 2019 - M. Hanuliak/B. Chropovský: Pohrebisko z 10.-11. storočia v Nitre-Horných Krškanoch. Slovenská archeológia 66, 2018, 113-193.

Hanuliak/Kuzma 2015 - M. Hanuliak/I. Kuzma: Mužla-Čenkov II. Osídlenie z 9.-13. storočia. Nitra 2015.

Hanuliak/Pieta 2014-M. Hanuliak/K. Pieta: Odraz christianizácie v hnutel'ných prameňoch z 9. stor. vo východných častiach Vel'kej Moravy. In: P. Kouřil a kolektiv: Cyrilometodějská misie a Evropa - 1100 let od př́chodu soluňských bratrů na Velkou Moravu. Brno 2014, 134-147.

Hanuliak/Rejholcová 1999 - M. Hanuliak/M. Rejholcová: Pohrebisko v Čakajovciach (9.-12. storočie). Vyhodnotenie. Bratislava 1999.
Hanuliak/Zábojník 1982 - M. Hanuliak/J. Zábojník: Pohrebisko zo 7.-8. stor. v Čataji, okr. Bratislava-vidiek. Archeologické rozhledy 34, 1982, 492-503.

Hochmanová-Vávrová 1962 - V. Hochmanová-Vávrová: Velkomoravské pohřebiště ve Starém Měste „Na Valách“. Výzkum v letech 1957-1959. Časopis Moravského Zemského Musea v Brně 47, 1962, 201-256.

Holčík 1991 - Š. Holčík: Vel'komoravské pohrebisko v Bíni. Zborník SNM 85. Archeológia 1, 1991, 85-104.

Horňák 2006 - M. Horňák: Príspevok k historickej interpretácii sklených korálikov v severovýchodoalpskej oblasti lužickej kultúry a vo vekerzugskej kultúre. Studia historica Nitriensia 13, 2006, 37-46.

Horáčková/Strouhal/Vargová 2004 - L. Horáčková/E. Strouhal/L. Vargová: Základy paleopatologie. Panoráma biologické a sociokultúrní antropologie 15. Brno 2004.

Horváthová 1995 - E. Horváthová: Apotropajné predmety. In: J. Botík/J. Slavkovský (ed.): Encyklopédia l'udovej kultúry Slovenska 2. Bratislava 1995, 21.

Hrubý 1955 - V. Hrubý: Staré Město. Velkomoravské pohřebiště „Na valách". Praha 1955.

Hrubý 1965 - V. Hrubý: Staré Město. Velkomoravský Velehrad. Praha 1965.

Husár 2014 - M. Husár: Žrd’ovo-bodné zbrane včasného stredoveku v Karpatskej kotline. 1. diel. Typológia a jej vyhodnotenie. Nitra 2014.

Chorvátová 2007 - H. Chorvátová: Horizonty byzantsko-orientálneho šperku na tzv. vel'komoravských pohrebiskách. In: V. Turčan (zost.): Byzantská kultúra a Slovensko. Zborník štúdií. Zborník SNM. Archeolológia. Supplementum 2. Bratislava 2007, 83-110.

Chorvátová 2009 - H. Chorvátová: Kultúrno-historický význam gombíkov. Studia Mediaevalia Bohemica 1, 2009, 7-19.

Chropovský 1957 - B. Chropovský: Slovanské pohrebisko z 9. stor. vo Vel'kom Grobe. Slovenská archeológia 5, 1957, 174-239.

Chropovský 1962 - B. Chropovský: Slovanské pohrebisko v Nitre na Lupke. Slovenská archeológia 10, 1962, 175-240.

Chropovský 1964 - B. Chropovský: Stručné dejiny Nitry. In: J. Lajoš (zost.): Nitra slovom i obrazom. Nitra 1964, 7-17.

Chropovský 1977 - B. Chropovský: Slovanské kostrové pohrebisko v Nitre-Dolných Krškanoch. AVANS 1976, 1977, 136-139.

Chropovský 1978 - B. Chropovský: Pohrebisko z 9.-10. storočia v Nitre pod Zoborom. Slovenská archeológia 26, 1987, 99-122.

Chropovský 1986a - B. Chropovský: Nálezová správa 11 498/86. Archeologický ústav SAV. Nitra 1986.

Chropovský $1986 b$ - B. Chropovský: Nálezová správa 11 705/86. Archeologický ústav SAV. Nitra 1986.

Jágerová 2001 - Slovenský pohreb. In: J. Botík (zost.): Obyčajové tradície pri úmrtí a pochovávaní na Slovensku s osobitým zretelom na etnickú a konfesionálnu mnohotvárnost'. Bratislava 2001, 13-31.

Jończyk 2013 - L. Jończyk: Zapinky podkowiaste w kontexście europejskich analogii. In: J. Kalagi (red.): Gród pogranicza polsko-ruskiego z X-XIII wieku. Warszawa Pekowice 2013, 41-51.

Justová 1990 - J. Justová: Dolnorakouské Podunají v raném středověku. Slovanská archeologie k jeho osídlení v 6.-11. století. Praha 1990.

Kalousek 1971 - F. Kalousek: Břeclav-Pohansko I. Velkomoravské pohřebiště u kostela. Brno 1971. 
Klanica 1970 - Z. Klanica: Pokus o třídění keramiky z Mikulčic. In: B. Klíma (ed.): Sborník Josefu Poulíkovi k šedesátinám. Brno 1970, 103-114.

Klanica 1985 - Z. Klanica: Mikulčice-Klášteřisko. Památky archeologické 76, 1985, 474-539.

Klanica 1986 - Z. Klanica: Počátky slovanského osídlení našich zemí. Praha 1986.

Klanica 2006a-Z. Klanica: Nechvalín, Prušánky. Čtyři slovanská pohřebiště I. Př́spěvek ke chronologii časně středověké hmotné kultury ve střední Evropě. Spisy AÚ AV ČR 28. Brno 2006.

Klanica 2006b-Z. Klanica: Nechvalín, Prušánky. Čtyřri slovanská pohřebiště II. Př́spěvek ke chronologii časně střredověké hmotné kultury ve střední Evropě. Spisy AÚ AV ČR 28. Brno 2006

Kozlowski 2004 - T. Kozlowski: Sczatky dziece w antropologii historycznej. In: W. Dzeieduszycki/J. Wrzesziński (red.): Dusza maluczka a strata ogromna. Funeralia Lednickie 6. Poznań 2004, 79-85.

Kouřil 2005a - P. Kouřil: Frühmittelalterliche Kriegergräber mit Flügellanzen und Sporen des Typs Biskupija-Crkvina auf mährische Nekropolen. In: Kouřil 2005b, 67-97.

Kouřil 2005b - P. Kouřil (Hrsg.): Die frühmittelalterliche Elite bei den Völkern des östlichen Mitteleuropa. Spisy AÚ AV ČR 25. Brno 2005.

Kouřil 2014 - P. Kouřil: Raně středověký bojovnícky hrob z Hradce nad Moravicí. Slovenská archeológia 52, 2014, $55-76$.

Kouřil/Tymonová 2013 - P. Kouřil/M. Tymonová: Slovanský kostrový mohylník v Stěbořicích. Spisy AÚ AV ČR 34. Brno 2013.

Kraskovská 1954 - L'. Kraskovská: Staroslovanské pohrebište v Máste pri Bratislave. Slovenská archeológia 2, 1954, 144-152.

Kraskovská 1965 - L. Kraskovská: Slovanské pohrebisko v Kopčanoch. Zborník SNM 59. História 5, 1965, 19-49.

Kraskovská 1969 - L. Kraskovská: Slovanské pohrebisko v Kopčanoch. Zborník SNM 63. História 9, 1969, 53-74.

Kraskovská/Paulík 1978 - L'. Kraskovská/J. Paulík: Vel'komoravské pohrebisko v Tvrdošovciach. Zborník SNM 72. História 18, 1978, 83-119.

Krumphanzlová 1972 - Z. Krumphanzlová: Die Austattung der Burgwallzeitfriedhöfe in Böhmen und ihre Bedeutung. Vznik a počátky Slovanů 7, 1972, 179-206.

Kuzma 2001 - I. Kuzma: Hrob z Nitry-Dolných Krškán. AVANS 2000, 2001, 103, 104.

Kovács 1982 - L. Kovács: Die Waffen der Landnehmenden Ungarn: Säbel, Kampfäxte, Lanzen. Mitteilungen des Archaeologischen Instituts des Ungarischen Akademie der Wischenschaften 10-11, 1982, 243-255, 433-438.

Kurasiński 2002 - T. Kurasiński: Co otwieral klucz znaleziony w grobie. In: A. Abramowicz/J. Majk (red.): Budownictwo i budowliane v przeszlości. Lódź 2002, 185-208.

Lauermann/Scheinblechner 2017 - E. Lauermann/W. Scheinblechner: Ein frühmittelalterlicher Schmiededepotfund von Wegscheid am Kamp, Niederösterreich. Slovenská archeológia 65, 2017, 81-98.

Liptáková 1963 - Z. Liptáková: Slovanské pohrebisko z X.-XI. storočia v Úlanoch nad Žitavou. Slovenská archeológia 11, 1963, 223-236.

Lukačka 2002 - J. Lukačka: Cestná siet’ v Nitre a v jej najbližšom okolí v 13. a 14. storočí. In: R. Marsina (zost.): Nitra v slovenských dejinách. Martin 2002, 208-211.

Macháček 2001 -J. Macháček: Studie k velkomoravské keramice. Metody, analýzy a syntézy, modely. Brno 2001.
Macháček a i. 2016 - J. Macháček/P. Dresler/R. Přichystalová/V. Sládek: Břeclav-Pohansko VII. Kostelní pohřebiště na Severovýchodním předhradí. Brno 2016.

Marek/Kostelníková 1998 - O. Marek/M. Kostelníková: Die Spinnwirtel aus Mikulčice. In: L. Poláček (Hrsg.): Studien zum Burgwall von Mikulčice III. Brno 1998, 171-325.

Marešová 1983 - K. Marešová: Uherské Hradiště-Sady. Staroslovanské pohřebiště na Horních Kotvicích. Brno 1983.

Marsina 1977 - R. Marsina: Nitra vo včasnom a vrcholnom stredoveku. In: J. Fojtík (zost.): Nitra. Bratislava 1977, $28-41$.

Mazuch 2013 - M. Mazuch: Velkomoravské keramické okruhy a tzv. mladši velkomoravský horizont v Mikulčicích. Spisy AÚ AV ČR 45. Brno 2013.

Mazuch/Hladík/Skopal 2017 - M. Mazuch/M. Hladík/R. Skopal: Úpravy hrobových jam a dřevěné konstrukce v hrobech na pohřebištích velké Moravy (sociální, duchovní a chronologický fenomén). Brno 2017.

Měřínský 1985 - Z. Měřínský: Velkomoravské kostrové pohřebiště ve Velkých Bílovicích. Brno 1985.

Mugurévičs 1977 - É. Mugurévičs: Olinkal aun Lokstenes Pilsnovadli. 3.-15. gs archeologiskie pieminekli. Riga 1970.

Oxenstierna 1966 - E. G. Oxenstierna: Die Wikinger. Stuttgart 1966.

Pavlovičová 1996 - E. Pavlovičová: K vypovedacej schopnosti gombíka u naddunajských Slovanov v 9. storočí. Slovenská archeológia 44, 1996, 95-153.

Pavlů 1971 -I. Pavlů: Pražskákeramika 12. a 13. století. Praha 1971.

Pawlik 2002 - J. J. Pawlik: Sposoby obchodzenia się z ciałem zmarłego z perspektywy antropologii kultury. In: Wrzesziński 2002, 29-40.

Petényi 1994-S. Petényi: Eggs. In: S. Petényi (ed.): Games and Toys in medieval and early modern Hungary. Krems 1994.

Plachá/Hlavicová/Keller 1990 - V. Plachá/J. Hlavicová/I. Keller: Slovanský Devín. Bratislava 1990.

Pleiner 1961 - R. Pleiner: Slovanské sekerovité hrivny. Slovenská archeológia 9, 1961, 405-450.

Pleiner 1962 - R. Pleiner: Staré evropské kovářství. Praha 1962.

Pollex 2000 - A. Pollex: Betrachtungen zu jungslawischen Mehrfachbestattungen. Ethnographisch-Archäologische Zeitschrift 41, 2000, 407-422.

Poláček/Marek/Skopal 2000 - L. Poláček/O. Marek/R. Skopal: Holzfunde aus Mikulčice. In: L. Poláček (Hrsg.): Studien zum Burgwall von Mikulčice IV. Brno 2000, 177-302.

Pošvár̆ 1963 - J. Pošvář: Velkomoravské železné hrivny jako platidlo. Numismatické listy 5, 1963, 1-11.

Poulík 1957 - J. Poulík: Výsledky výzkumu na velkomoravském hradišti „Valy“ u Mikulčic. Památky archeologické 48, 1957, 241-388.

Prokeš 2007 - L. Prokeš: Posmrtné změny a jejich význam při interpretaci pohřebního ritu (ke vztahu mezi archeologií a forenzními vědami). Archaeologica Mediaevalis Moravica et Silesiana. Supplementum 1. Brno 2007.

Přichystalová 2007 - R. Přichystalová: Detské hroby z južného predhradia vel'komoravského hradiska na Pohansku pri Břeclavi. Študijné zvesti Aú SAV 42, 2007, 163-184.

Přichystalová 2014 - R. Přichystalová: Olomouc-Nemilany. Stručná charakteristika reněstředověkého pohřebiště. In: R. Přichystalová/M. Kalábek (ed.): Raněstředověképohřebiště Olomouc-Nemilany. Katalog. Brno 2014, 207-272.

Profantová 2003 - N. Profantová: Mikulčice - pohřebiště u 6. kostela: pokus o chronologické a sociální zhodnocení. In: N. Profantová/B. Kavánová: Mikulčice - pohřebiště u 6. a 12. kostela. Spisy AÚ AV ČR 22. Brno 2003.

Profantová 2015 - N. Profantová: Klecany. Raně středověká pohřebiště. 1. svazek. Praha 2015. 
Rajnič 1941 - A. Rajnič: Nálezová správa 421/41. Archeologický ústav SAV. Nitra 1941.

Rejholcová 1995a - M. Rejholcová: Pohrebisko v Čakajovciach (9.-12. storočie). Analýza. Nitra 1995.

Rejholcová 1995b - M. Rejholcová: Pohrebisko v Čakajovciach (9.-12. storočie). Katalóg. Nitra 1995.

Ruttkay, A. 1976 - A. Ruttkay: Waffen und Reiterausrüstung des 9. bis zur ersten Hälfte des 14. Jahrhunderts in der Slowakei (II). Slovenská archeológia 24, 1976, 245-395.

Ruttkay, A. 2002 - A. Ruttkay: Odraz politicko-spoločenského vývoja vo vel'komoravskom vojenstve a výstroji. In: A. Ruttkay/M. Ruttkay/P. Šalkovský (ed.): Slovensko vo včasnom stredoveku. Nitra 2002, 105-121.

Ruttkay, M. 2002 - M. Ruttkay: Mittelalterliche Siedlung und Gräberfeld in Bajč-Medzi kanálmi (Vorbericht). Slovenská archeológia 50, 2002, 245-322.

Ruttkay, M. 2004-M. Ruttkay: Záchranný výskum v Nitre-Dolných Krškanoch. AVANS 2003, 2004, 153-155.

Ruttkay, M. 2005 - M. Ruttkay: Niektoré nové objavy v Nitre a okolí zo včasného a vrcholného stredoveku. In: M. Ruttkay (ed.): Dávne dejiny Nitry a okolia. Nitra 2005, 55-75.

Samuel/Pomfyová 2015 - M. Samuel/B. Pomfyová: Bratislava, čast' Devín, hrad. Zaniknuté stredoveké stavby. In: B. Pomfyová (zost.): Stredoveký kostol. Historické a funkčné premeny architektúry. 1. zväzok. Bratislava 2015, 97-100.

Sláma 1990 - J. Sláma: Slovanské pohřebiště. In: M. Buchvaldek/J. Zeman (ed.): Lochenice. Z archeologických výzkumi na katastru obce. Praehistorica 16. Praha 1990, 103-133.

Slivka 1998 - M. Slivka: Rekonštrukcia cestnej siete na Slovensku (Súčasný stav bádania a jeho perspektívy). Archaeologia historica 23, 1998, 259-279.

Smetánka 2003 - Z. Smetánka: Archeologické etudy. Osmnáct kapitol o poznávání středověku. Praha 2003.

Smetánka 2014 - Z. Smetánka: Vejce a skořápky vajec. In: J. Frolík (ed.): Pohřebiště v Lumbeho zahradě na Pražském hradě II. Castrum Pragense 12. Praha 2014, 117-128.

Schmitt 2004 - J.-C. Schmitt: Svět středověkých gest. Praha 2004.

Sýkorová 1991 - L. Sýkorová: Viera a vedomosti l’udu v Čičmanoch v minulosti a dnes. Vlastivedný zborník Považia 16, 1991, 169-179.

Szőke 1992 - B. M. Szőke: Karolingerzeitliche Gräberfeld I-II von Garabonc-Ófalu. Die Karolingerzeit im unteren Zalatal. Antaeus 21, 1992, 41-203.

Szücsi 2013 -F. Szücsi: Avar kori baltak, bárdok szekercék és fokosok. Baltafélék a 6-8. századi Kárpát-medencében. Alba Regia 42, 2013-2014, 113-188.

Štefanovičová 1995 - T. Štefanovičová: Slovensko v časoch Svätuplukových. Sborník Prací Filosofické fakulty Brněnské university E 40, 1995, 29-35.

Tobias 2007 - B. Tobias: Nehány érdekés tárgy a Zillingtal-Unterer Kapellenberg D. 41 sírból. Csatfibulák és ecsetek. Archaeologiai Értesitő 132, 2007, 325-341.
Točík 1971 - A. Točík: Flachgräberfelder aus dem IX. und X. Jahrhundert in der Südwestslowakei. Slovenská archeológia 19, 1971, 135-276.

Točík 1992 - A. Točík: Materiály k dejinám južného Slovenska v 7.-14. storočí. Študijné zvesti Aú SAV 28, 1992, 5-248.

Tomka 2000 - P. Tomka: Gräberfeld aus dem 9. Jh. in Páli-dombok. (Kom. Györ-Sopron-Moson). Communicationes Archaeologicae Hungariae 2000, 177-210.

Tomková 2005 - K. Tomková: Pohřební ritus na Pražském hradě a jeho předpolích ve středověku a novověku Charakteristika a vývoj. In: K. Tomková (ed.): Pohřbívaní na Pražském hradě a jeho předpolích I/1. Castrum Pragense 7. Praha 2005, 159-196.

Turčan 1993 - V. Turčan: K funkcii vody v pohrebnom rituáli včasnostredovekých Slovanov. In: E. Krekovič (zost.): Kultové a sociálne aspekty pohrebného rítu od najstarších čias po súčasnost'. Bratislava 1993, 55-57.

Ungerman 2007 - Š. Ungerman: Raně středověké pohřebiště $v$ Dolních Věstonicích-Na pískách. Disertační práce. Masarykova univerzita. Brno 2007. Nepublikované.

Venclová 2005 - N. Venclová: Sklářství a Keltové. In: O. Drahotová (zost.): Historie sklářské výroby v českých zemích 1. Od počátků do konce 19. století. Praha 2005, 29-38.

Vendtová 1962 - V. Vendtová: Slovanské pohrebisko v Ladiciach, okr. Nitra. Archeologické rozhledy 14, 1962, 381, 397-404.

Vendtová 1969 - V. Vendtová: Slovanské osídlenie Pobedima a okolia. Slovenská archeológia 17, 1969, 119-224.

Vendtová/Rejholec 1963 - V. Vendtová/E. Rejholec: Slovanské pohrebisko v Ipel'skom Sokolci. Slovenská archeológia 11, 1963, 237-246.

Vignatiová 1992 - J. Vignatiová: Břeclav-Pohansko II. Slovanské osídlení jižního předhradí. Brno 1992.

Vlastivedný slovník 1977 - Vlastivedný slovník obcí na Slovensku 1. Bratislava 1977.

Vereščáková 2014 - J. Vereščáková: Fenomén orientácie v hrobovej archeológii vo včasnom stredoveku. Musaica 28. Zborník Filozofickej fakulty Univerzity Komenského, 2014, 113-126.

Vondráková a i. 2011 - M. Vondráková/B. Matejovičová/ B. Kolena/C. Ambros/Z. Miklíková/M. Fabiš/M. Martiniaková/M. Bauerová/M. Bauer/R. Omelka/L. Luptáková: Paleopatologické nálezy z vybraných archeologických výskumov na Slovensku. Nitra 2011.

Wawrzeniuk 2002 - J. Wawrzeniuk: Grób i jego wartości poznawcze. In: Wrzesziński 2002, 75-82.

Wozny 2002 - J. Wozny: Symbolika śmerczi i rytualow pogrzebowych $\mathrm{w}$ kulturach wcześnotradicijnych na ziemiach polskich. In: Wrzesziński 2002, 45-58.

Wrzesziński 2000 -J. Wrzesziński: Czarownice-próba podsumovania warsztatów. In: J. Wrzesziński (red.): Czarownice. Funeralia Lednickie 2. Poznań 2000, 179-199.

Wrzesziński 2002 - J. J. Wrzesziński (red.): Popiol i kosć. Funeralia Lednickie 4. Poznań 2002.

Zábojník 2009 - J. Zábojník: Slovensko a avarský kaganát. Bratislava 2009

PhDr. Milan Hanuliak, DrSc.

Archeologický ústav SAV

Akademická 2

SK - 94921 Nitra

milan.hanuliak@savba.sk
Abstract translated by Ludmila Hanuliaková Zusammenfassung übersetzt von Lubomír Novotný 


\title{
Das Gräberfeld aus dem 9. Jahrhundert in Nitra-Dolné Krškany
}

\author{
Milan Hanuliak - + Bohuslav Chropovský
}

\author{
ZUSAMMENFASSUNG
}

Die Fundstelle befindet sich im Stadtteil Dolné Krškany, der am Rand des Kernes von historischer Nitra liegt (Abb. 1). Ihre archäologische Untersuchung im Jahr 1976 hat die Vernichtung der Gräber während des Aufbaues des Betriebes Idea (Abb. 2) hervorgerufen. Während dieser Rettungsaktion wurden 54 Gräber untersucht. Mehr als 20 weitere Gräber konnten in den nicht untersuchten Randabschnitten und im mittleren Teil der Nekropole (Abb. 3) gewesen sein. Die registrierten Gräber sind auf der Fläche nicht regelmäßig verteilt. Laut der Verwandtschaftsverhältnisse wurden sie mit unterschiedlicher Intensität in acht Gruppen mit verschiedener Zahl der Gräber angesammelt.

Die Äußerungen der Bestattungssitten sind sehr ähnlich. Die Abweichungen sind nicht häufig, von den Standardäußerungen unterscheiden sie sich minimal. Bei den Lagen der oberen Extremitäten wurden z. B. nur 11 Fälle von mäßigen Formen der Abweichungen von drei Typen (Abb. 4: b-d) registriert. Eine außergewöhnliche Lage des Körpers mit absichtsvoll einbezogenen unteren Extremitäten ist nur bei einem Kind aus dem Grab 21 (Taf. XI) vorgekommen. Die sterblichen Überreste eines erwachsenen Mannes wurden zufällig beschädigt, einige seiner Knochen hat man in eine neue Grabgrube (Grab 25) mit beschränktem Platz (Taf. XII) niedergelegt. Zu absichtsvollen Verlagerungen der Knochen ist es bei den Gräbern 5, 12 und 13 (Taf. II; XII) gekommen. Ihre Entstehung kann mit Verteidigungseingriffen, durchgeführt durch die Verbliebenen im Einklang mit den vorchristlichen Prinzipien, verbunden werden. Ihre Verwendung wurde auch bei der Ortung der Azimute der Orientierung der Bestatteten, bei der Platzierung des Gräberfeldes in damaligem Naturmilieu, der Art und Weise der Ausstattung der Verstorbenen auf den Weg ins Schattenreich, bestätigt. Belege über Holz bei der Herrichtung der Grabgruben sind in den Gräbern 4, 44, 48 und 51 (Taf. II; XIX; XX; XXI) erhalten geblieben. Es handelt sich um begrenzte Reste, die ursprünglich als Unterlage, Bedeckung und Seitenbekleidung gedient hatten. In 11 Gräbern hat man ein überdurchschnittliches Volumen der Grabgruben, das als Indikator einer höheren Stellung des Verstorbenen im Familienbund dient, festgelegt.

Das Grabinventar stammt aus 38 Gräbern. Die Kollektion besteht nur aus 30 Grundtypen der Gegenstände und ihren Varianten (Abb. 6; 8). Ihre Vertreter wurden anhand der Nutzung in fünf Materialgruppen mit unterschiedlicher Frequenz des Vorkommens (Abb. 5) eingereiht. Zu Mangeln der verarbeiteten Kollektion gehört ihre Zusammensetzung. Problematisch ist vor allem das dominante Vorkommen von Messern und keramischen Gefäßen, die zu den Gegenständen des täglichen Bedarfes und des kultischen Charakters (Abb. 9; 12), mit einer niedrigen Datierungsfähigkeit, gehören. Mehr qualitätsgerechte Informationen gewähren auch nicht die Ohrringe des donauländischen und des Veligrad-Typs (Abb. 6: 1-9). Ihre nicht zahlreichen Exemplare kombinieren sich jedoch nicht unter sich. In den Gräbern werden sie von Gegenständen mit niedriger Aussagefähigkeit (Abb. 7: a-g) ergänzt. Noch dazu, sie befinden sich in Gräbern, die in zwei Teilen der Nekropole platziert sind, getrennt von einem nicht untersuchten Teil (Abb. 3). Nur in beschränktem Maß können zu der chronologischen Spezifikation zwei Vertreter der Waffen (Abb. 8: 22, 23), fünf Eimer (Abb. 8: 25), neun keramische Gefäße aus der Gruppe B, C (Abb. 10; 11), ausnahmsweise auch ein Knopf mit gerippter Oberfläche (Abb. 6: 12), verwendet werden. Wegen unzureichender Qualität der zugänglichen Angaben kann die Beisetzung auf dem Gräberfeld nur rahmenweise in die erste und zweite Hälfte des 9. Jh. eingereiht werden. Für die Fortsetzung seiner Verwendung im 10. Jh. fehlen typische Indikatoren. Die Dauer der Benutzung des Gräberfeldes können wir nicht festlegen, weil weder sein Anfangs- noch der AbschlussAbschnitt bekannt sind. Mit definitiver Gültigkeit kann auch in Hinweisen notierter kontinuierlicher Fortgang in der Bestattung, gerichtet vom westlichen in den östlichen Teil der Nekropole, nicht bestätigt werden.

Trotz einer nicht vollständigen Untersuchung weist die aufgearbeitete Nekropole Anteile einer sophistischen Raumstruktur auf. Ursprünglich bestand sie aus drei horizontalen Linien, die von einigen Gruppen von Gräbern gefüllt waren. In die obere Linie aus der älteren Phase der Bestattung gehört die I. und II. Gruppe. Die untere Linie aus dem jüngeren Horizont ist aus der V.-VIII. Gruppe zusammengesetzt. Den Schwerpunkt von der mittleren Reihe, die zwischen ihnen liegt, kennen wir nicht. Außer der III. und IV. Gruppe sollten in diesen Streifen ungefähr noch zwei weitere Gruppen der Gräber gehören. Das fehlende Forschungsinteresse um Nachforschung des tangierten Teiles auch nach der aufgeschichteten Deponie der Erde hat ein negatives Präzedens geschaffen. Dieses hat sich in Anstieg der negativen Äußerungen, die die Datierung und Bildung eines mehr komplexen Bildes über der bestattenden Kommunität beeinflussten, offenbart. Es kann noch erwähnt werden, dass sich im östlichen Abschnitt des Gräberfeldes 38 Gräber und im westlichen 16 Gräber befanden haben. Die Proportionalität der Verstorbenen in jedem von ihnen hat keine mehr wesentlichen Unterschiede erworben. Die Zahl der Kinder erfasst zum Beispiel den Wert von 37,5 \% und 39,5 \%. Im westlichen Segment der Nekropole sind erwachsene Männer gegenüber den Frauen ungefähr um denselben Teil zahlreicher als die Frauen gegenüber den Männern in den östlichen Gräberfeldgrä- 
bern. In dieser Zone kamen unter den Bestatteten zwei Kinder vom jüngsten Alter (Inf. I) und zwei Männer im Greisenalter (M, Sen.) vor.

Zur Präzisierung der sozialen Struktur der lokalen Kommunität trägt die modifizierte Skala der Faktoren bei. Eine wichtige Rolle spielen in ihr die Grabgruben mit überdurchschnittlichem Volumen, die Waffen, der Schmuck

Abb. 1. Das Gebiet von Nitra mit der markierten Lage der bearbeitenden Fundstelle.

Abb. 2. Der südliche Abschnitt des Katasters von Dolné Krškany mit der markierten Lage des Gräberfeldes.

Abb. 3. Nitra-Dolné Krškany. Plan des Gräberfeldes. Legende: $\mathrm{a}$ - Grab mit Umrissen der Grabgrube; $b$-Skelett eines Individuums ohne Umrisse der Grabgrube; cUmfassungslinien der Gruppen von Gräbern; dI-VIII - Markierung der Gruppen von Gräbern.

Abb. 4. Nitra-Dolné Krškany. Die Verteilung der Gräber mit verfolgten Elementen. Legende: a - überdurchschnittliches Volumen der Grabgrube; b - rechter Vorderarm im Becken; c - linker Vorderarm im Becken; $d$ - beide Vorderarme im Becken; e-Holzüberreste von der Ausstattung der Grabgrube.

Abb. 5. Nitra-Dolné Krškany. Das Vorkommen der Haupttypen der Gegenstände und ihrer Varianten in den materiellen Gruppen. 1 - Schmuck; 2 - Bestandteile der Kleidung; 3 - Gegenstände des täglichen Bedarfes; 4 - Waffen; 5 - Gegenstände kultischen Charakters.

Abb. 6. Nitra-Dolné Krškany. Typologische Zusammensetzung des Schmuckes und der Bestanteile der Kleidung. 1-10 - den Kopf schmückende Gegenstände; 11 - den Hals schmückende Gegenstände; 12-14 - Bestandteile der Kleidung.

Abb. 7. Nitra-Dolné Krškany. Die Verteilung der Gräber mit Schmuck. Legende: a - Ohrring (Typ 1); b-Ohrring (Typ 2); c - Ohrring (Typ 3); d - Ohrring (Typ 4); e Ohrring (Typ 5); f - Ohrringe (Typ 6-9); g - Ohrringe (Typ 10); h - Perlen (Typ 11).

Abb. 8. Nitra-Dolné Krškany. Typologische Zusammensetzung der Gegenstände. 15-21 - Gegenstände des täglichen Bedarfes; 22, 23 - Waffen; 24-30 - Gegenstände des kultischen Charakters.

Abb. 9. Nitra-Dolné Krškany. Verteilung der Gräber mit Gegenständen des täglichen Bedarfes. Legende: a Messer (Typ 15); b - Abschlag (Typ 18); c - Feuerstahl (Typ 17); d - Pfriem (Typ 19); e - Spinnwirtel (Typ 21); f - Nadelbüchse, Nadel.

Abb. 10. Nitra-Dolné Krškany. Vertreter von keramischen Gefäßen von der Gruppe C.

Abb. 11. Nitra-Dolné Krškany. Vertreter von keramischen Gefäßen. 1 - Gefäß von der Gruppe C; 2, 3 - Gefäße von der Gruppe B.

Abb. 12. Nitra-Dolné Krškany. Verteilung der Gräber mit Gegenständen kultischen Charakters. Legende: a - keramisches Gefäß von der Gruppe A (Typ 24); b - keramisches Gefäß von der Gruppe B; c - keramisches Gefäß von der Gruppe C; d - Eimer (Typ 25); e - Fleischbeilage (Typ 26); f - Ei (Typ 27); g - Amulett (Typ 28-30).

Abb. 13. Nitra-Dolné Krškany. Verteilung der Gräber mit verfolgten Elementen. Legende: a - überdurchschnittliches Volumen der Grabgrube; $b$ - Fleischbeilage (Typ 26); c - Eimer (Typ 25); d - Rasiermesser (Typ 16); und einige Bestandteile der Kleidung, die Rasiermesser, die Eimer und Beilagen der Fleischkost (Abb. 13). Durch ihre Beihilfe kann eine nicht zahlreiche Gruppe von Individuen mit höherer, bzw. mehr prestigeträchtiger Stellung in der lokalen Kommunität ausgegliedert werden. Zu ihr gehören die Bestatteten in den Gräbern 4, 5, 6, 13, 14, 15 und 18 (Taf. I; II; IV; VI-XI).

e - Waffe (Typ 22, 23); f - Bestandteile der Kleidung (Typ 12-14).

Abb. 14. Svätý Peter. Vorkommen der Haupttypen der Gegenstände und ihrer Varianten in den materiellen Gruppen. 1 - Schmuck; 2 - Bestandteile der Kleidung; 3 - Gegenstände des täglichen Bedarfes; 4 - Waffen; 5 - Gegenstände kultischen Charakters.

Abb. 15. Nitra-Dolné Krškany. Vorkommen der Haupttypen der Gegenstände und ihrer Varianten in den materiellen Gruppen. 1 - Schmuck; 2 - Bestandteile der Kleidung; 3 - Gegenstände des täglichen Bedarfes; 4 - Waffen; 5 - Gegenstände kultischen Charakters.

Abb. 16. Nitra-Dolné Krškany. Vorkommen der Individuen unterschiedlichen Geschlechtes und Alters in Teilen des Gräberfeldes. 1 - Kinder; 2 - erwachsene Männer; 3 erwachsene Frauen; a - westlicher Teil; b - östlicher Teil.

Taf. I. Gräber 1-4, Pläne und Funde. Maßstab: a - 1: 1, 3: 1; $\mathrm{b}-2: 1,4: 3,4$.

Taf. II. Gräber 4 und 5, Pläne und Funde. Maßstab: a - 4: 1; b-4: 2, 5, 6, 5: $1-4$.

Taf. III. Grab 6, Plan und Funde. Maßstab: a - 6: 2; b - 6: 1 .

Taf. IV. Gräber 7 und 8, Pläne und Funde.

Taf. V. Gräber 8-10, Pläne und Funde. Maßstab: a - 8: 4, 10: $2 ; b-10: 1$.

Taf. VI. Gräber 11-13, Pläne und Funde. Maßstab: a - 11: 2; b-13: 1 .

Taf. VII. Gräber 13 und 14, Funde. Maßstab: a - 13: 3, 4, b 14: 1, 2; c-13: 2, 14: 4, 5 .

Taf. VIII. Gräber 14 und 16, Pläne und Funde. Maßstab: $a-14: 7 ; b-16: 1-3$.

Taf. IX. Grab 15, Plan und Funde. Maßstab: a - 15: 2; b-15: 1.

Taf. X. Gräber 17 und 18, Pläne und Funde. Maßstab: a 18: 4; b-17: 1, 18: 1, 2; c - 18: 3.

Taf. XI. Gräber 19-22 und 24, Pläne und Funde. Maßstab: $\mathrm{a}-19: 1 ; \mathrm{b}-20: 1$.

Taf. XII. Gräber 23, 25 und 26, Pläne und Funde. Maßstab: $\mathrm{a}-23: 2 ; \mathrm{b}-23: 1,26: 1$.

Taf. XIII. Gräber 27 und 28, Pläne und Funde. Maßstab: a - 27: 5; b-27: 1, 2; c - 27: 3, 4, 28: 1 .

Taf. XIV. Gräber 29-31, Pläne und Funde. Maßstab: a 30: $1 ; \mathrm{b}-29: 1$.

Taf. XV. Gräber 32 und 33, Pläne und Funde. Maßstab: a 32: $1,33: 5 ; b-33: 1-3 ; c-33: 4$.

Taf. XVI. Gräber 34, 35 und 37, Pläne und Funde. Maßstab: a - 37: 2; b-34: 1, 2, 35: $1 ; \mathrm{c}-37: 1$.

Taf. XVII. Gräber 36, 38-42 und 45, Pläne.

Taf. XVIII. Grab 43, Plan und Funde. Maßstab: a - 43: 2, $3 ; b-43: 1$.

Taf. XIX. Gräber 44 und 46, Pläne und Funde. Maßstab: a $-44: 2 ; 46: 1 ; b-44: 1$.

Taf. XX. Gräber 47-49, Pläne und Funde. Maßstab: a - 47: 1-4, 48: $1 ; b-49: 1-4$.

Taf. XXI. Gräber 50-54, Pläne und Funde. 
